\title{
Washing and Caustic Leaching of Hanford Tank Sludges: Results of FY 1995 Studies
}

B. M. Rapko

G. J. Lumetta

M. J. Wagner

August 1995

Prepared for

the U.S. Department of Energy

Contract DE-AC06-76RLO 1830

Pacific Northwest Laboratory Operated for the U.S. Department of Energy

by Battelle Memorial Institute 


\title{
DISCLAIMER
}

This report was prepared as an account of work sponsored by an agency of the United States Government. Neither the United States Government nor any agency thereof, nor Battelle Memorial Institute, nor any of their employees, makes any warranty, express or implied, or assumes any legal liability or responsibility for the accuracy, completeness, or usefulness of any information, apparatus, product, or process disclosed, or represents that its use would not infringe privately owned rights. Reference herein to any specific commercial product, process, or service by trade name, trademark, manufacturer, or otherwise does not necessarily constitute or imply its endorsement, recommendation, or favoring by the United States Government or any agency thereof, or Battelle Memorial Institute. The views and opinions of authors expressed herein do not necessarily state or reflect those of the United States Government or any agency thereof.

\author{
PACIFIC NORTHWEST LABORATORY \\ operated by \\ BATTELLE MEMORIAL INSTITUTE \\ for the \\ UNITED STATES DEPARTMENT OF ENERGY \\ under Contract DE-ACO6-76RLO, 1830
}

Printed in the United States of America

Available to DOE and DOE contractors from the Office of Scientific and Technical Information, P.O. Box 62, Oak Ridge, TN 37831; prices available from (615) $576-8401$.

Available to the public from the National Technical Information Service, U.S. Department of Commerce, 5285 Port Royal Rd., Springfield, VA 22161 


\section{DISCLAIMER}

Portions of this document may be illegible in electronic image products. Images are produced from the best available original document. 
PNL-10712

$\mathrm{UC}$

2036

WASHING AND CAUSTIC LEACHING OF HANFORD TANK SLUDGES: RESULTS OF FY 1995 STUDIES

B. M. Rapko

G. J. Lumetta

M. J. Wagner

August 11, 1995

Prepared for

the U.S. Department of Energy

under Contract DE-AC06-76RLO 1830

Pacific Northwest Laboratory

Richland, Washington 99352

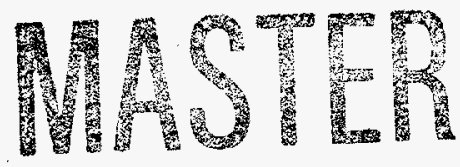




\section{Summary}

This report describes the sludge washing and caustic leaching tests conducted at Pacific Northwest Laboratory in FY 1995 under the Sludge Treatment Technology Development Task of the Tank Waste Remediation System (TWRS) Pretreatment Technology Development Project. The highlights from this work were as follows.

- Sludge washing and caustic leaching tests were performed on sludge composites from six Hanford single-shell tanks (B-111, BX-107, C-103, S-104, T-104 and T-111) and one double-shell tank (SY-103). The studies, designed to evaluate the current baseline pretreatment flowsheet, involved contacting the sludges once with $0.01 \mathrm{M} \mathrm{NaOH} / 0.01 \mathrm{M}$ $\mathrm{NaNO}_{2}$, followed by two contacts with $-3 \mathrm{M} \mathrm{NaOH}$, and finally three washes with $0.01 \mathrm{M} \mathrm{NaOH} / 0.01 \mathrm{M} \mathrm{NaNO}_{2}$. Except for the final washes, each step was performed at $100^{\circ} \mathrm{C}$. The settling behavior of the solids at each step, the elemental composition, radionuclide composition, and anion composition of the initial solids, the treated solids, and all aqueous solutions were measured to evaluate the effectiveness of the sludge washing and caustic leaching treatment.

- Particle sizes for the untreated sludges typically ranged around $1 \mu \mathrm{m}$ according to the number distribution, or between 1 to $5 \mu \mathrm{m}$ according to the volume distribution. In general, little change in particle size was observed as a result of sludge washing and caustic leaching.

- Solids settling behavior ranged widely from tank to tank. In general, the initial wash suspensions, containing $\sim 2.3 \mathrm{wt} \%$ solids, settled well. But poor settling behavior was observed for the caustic leach and final wash step, which contained $\sim 8 \mathrm{wt} \%$ solids.

- For the single-shell tank sludges, the only radionuclides removed to any great extent were ${ }^{137} \mathrm{Cs}$ and ${ }^{99} \mathrm{Tc}$. Small fractions of the transuranic elements (TRUs) and ${ }^{90} \mathrm{Sr}$ were removed from the double-shell tank sludge SY-103.

- If the wash and leach solutions from a given tank were combined and concentrated to $20 \mathrm{M} \mathrm{Na}$ in the final low-level waste form, most of the resulting materials would be below the limits for Nuclear Regulatory Commission Class C low-level waste. An exception to this is seen for $\mathrm{C}-103$ sludge, which (if no futher pretreatment is performed) would have a tranuranic concentration in the low-level waste near the $0.1 \mu \mathrm{g} / \mathrm{g}$ Class C limit. 
- The removal of bulk nonradioactive sludge constituents varied widely from sludge to sludge as indicated in Table S.1.

- The washing and leaching results were compared to phenomenological assumptions commonly used to describe $\mathrm{P}$ and $\mathrm{Al}$ leaching from tank sludges. In general, on a tankby-tank basis, these assumptions appear consistent with the observed behavior.

Exceptions include the removal of Al from tanks C-103 and S-104, and the removal of P from Tank T-104.

- The concentrations of the treated tank sludges were combined with the total mass of the sludges in their respective tanks together with Hanford Waste Vitrification Plant feed specifications to calculate the number of high-level waste glass canisters ( 1650 $\mathrm{kg} /$ canister) that would result from treated and untreated sludges on a tank-by-tank basis. On this basis, caustic leaching will result in reductions ranging from $7 \%$ to $91 \%$ in the amount of glass required to immobilize the waste, when compared to sludge washing alone.

- Two sludges responded poorly to the sludge washing and caustic leaching tests. When considered on a tank-by-tank basis, the high concentration of Al in treated S-104 sludge and the high concentration of $\mathrm{Cr}$ in treated SY-103 sludge could lead to large volumes of high-level waste glass. Alternative pretreatment methods for these specific tank sludges are currently being investigated.

\section{Reference}

Colton, N. G. 1995. Sludge Pretreatment Chemistry Evaluation: Enhanced Sludge Washing Separation Factors. PNL-10512, Pacific Northwest Laboratory, Richland, Washington. 
Table S.1. Summary of Sludge Components Removed by Sludge Washing and Caustic Leaching

Amount of Component Removed, \%

\begin{tabular}{|c|c|c|c|c|c|c|}
\hline Tank & Al & $\mathrm{Cr}$ & $\mathrm{Fe}$ & $\mathrm{Na}^{(\mathrm{a})}$ & $\mathrm{P}$ & $S$ \\
\hline B-111 & 2 & 40 & 0 & 91 & 91 & 100 \\
\hline BX-107 & 68 & 29 & 0 & 91 & 93 & 95 \\
\hline C-103 & 48 & 11 & 0 & 24 & 66 & (b) \\
\hline S-104 & 38 & 97 & 1 & 92 & (c) & 100 \\
\hline SY-103 & 90 & 12 & 25 & 99 & 98 & (b) \\
\hline T-104 & 62 & 27 & 0 & 40 & 55 & 100 \\
\hline T-111 & 13 & 63 & 0 & 85 & 72 & 67 \\
\hline
\end{tabular}

Concentration of Component in Untreated Sludge, g/g Dried Sludge

\begin{tabular}{|c|c|c|c|c|c|c|}
\hline Tank & $\mathrm{Al}$ & $\mathrm{Cr}$ & $\mathrm{Fe}$ & $\mathrm{Na}$ & $\mathbf{P}$ & $S$ \\
\hline B-111 & $3.0 \mathrm{E}-03$ & $3.1 \mathrm{E}-03$ & $4.6 \mathrm{E}-02$ & $2.4 \mathrm{E}-01^{(\mathrm{d})}$ & 4.1E-02 & $1.3 \mathrm{E}-02$ \\
\hline BX-107 & $3.5 \mathrm{E}-02$ & 2.3E-03 & $2.8 \mathrm{E}-02$ & $2.1 \mathrm{E}-01$ & $5.6 \mathrm{E}-02$ & $6.6 E-03$ \\
\hline C-103 & $1.4 \mathrm{E}-01$ & $1.6 \mathrm{E}-03$ & 2.0E-01 & $4.6 \mathrm{E}-02$ & $5.0 \mathrm{E}-03$ & (b) \\
\hline S-104 & $1.5 \mathrm{E}-01$ & 4.7E-03 & $3.4 \mathrm{E}-03$ & $2.0 \mathrm{E}-01$ & (e) & $6.7 \mathrm{E}-03$ \\
\hline SY-103 & 4.7E-02 & $1.3 \mathrm{E}-02$ & $4.1 \mathrm{E}-03$ & $2.8 \mathrm{E}-01$ & $7.8 \mathrm{E}-03$ & (b) \\
\hline T-104 & 4.7E-02 & $3.1 \mathrm{E}-03$ & $2.8 \mathrm{E}-02$ & $1.9 \mathrm{E}-01$ & $6.9 \mathrm{E}-02$ & $1.0 \mathrm{E}-02$ \\
\hline T-111 & $4.9 \mathrm{E}-03$ & $4.5 \mathrm{E}-03$ & $6.0 \mathrm{E}-02$ & 3.7E-01 & $2.6 \mathrm{E}-02$ & 5.7:E-03 \\
\hline
\end{tabular}

(a) Because $\mathrm{Na}$ was added in the form of $\mathrm{NaOH}$ during the leaching process, the amount of $\mathrm{Na}$ removed from the sludge could not be determined per se. The value reported here is the amount of $\mathrm{Na}$ found in the dried, leached, residue relative to that in the untreated sludge, i.e., $100-[100(f / i)]$, where $f$ is the amount of $\mathrm{Na}$ in the dried, washed, sludge and $i$ is the amount in the dried, untreated, sludge.

(b) Due to matrix effects, analyte could not be accurately determined.

(c) No $P$ was detected in this sludge sample.

(d) Due to analytical difficulties, reliable data for $\mathrm{Na}$ are not available for these untreated sludges; the $\mathrm{Na}$ concentrations reported here were taken from Colton 1995. 


\section{Acknowledgments}

The authors thank G. M. Richardson for assistance with performing the Tank C-103 sludge washing and caustic leaching test in the 325A Hot Cell facility. The authors also thank R. R. Odell, M. J. Lindberg, and A. L. Fishback of WHC for their assistance in performing the tests. The assistance of S. G. McKinley and other members of the Pacific Northwest Laboratory Analytical Chemistry Laboratory who contributed to this work is gratefully acknowledged. The authors thank W. C. Cosby, N. G. Colton, and J. L. Swanson for reviewing this document. 


\section{Contents}

Summary $\ldots \ldots \ldots \ldots \ldots \ldots \ldots \ldots \ldots \ldots \ldots \ldots \ldots \ldots \ldots \ldots \ldots \ldots$

Acknowledgments ........................... vii

Contents $\ldots \ldots \ldots \ldots \ldots \ldots \ldots \ldots \ldots \ldots \ldots \ldots \ldots \ldots \ldots \ldots \ldots$

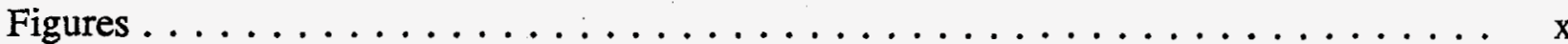

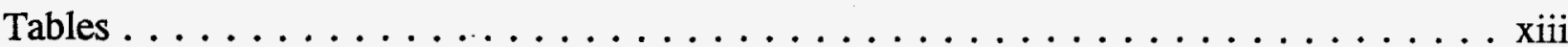

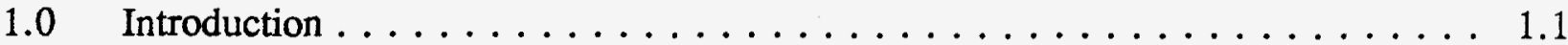

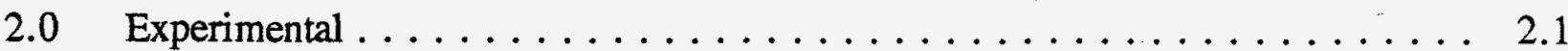

2.1 Materials . . . . . . . . . . . . . . . . . 2.1

2.2 Sludge Washing and Caustic Leaching Procedure . . . . . . . . . 2.2

2.3 Analytical Methods . . . . . . . . . . . . . . 2.4

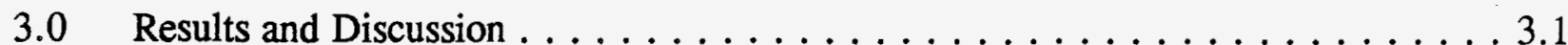

3.1 General Observations . . . . . . . . . . . . . . . . 3.1

3.2 Settling Behavior of the Sludge Solids . . . . . . . . . . . . 3.4

3.3 Particle Size Analysis of Sludges Before and After Washing and Leaching . . . . . . . . . . . . . . . . . 3.9

3.4 Behavior of Nonradioactive Components During Sludge Washing and Caustic Leaching

3.5 Behavior of Anionic Components During Sludge Washing and Caustic Leaching .

3.6 Radionuclide Behavior During Sludge Washing and Caustic Leaching

3.7 Comparison of the Sludge Washing and Caustic Leaching Results to the Tank Waste Remediation Studies Planning Assumptions

3.8 Impact on High-Level Waste Glass Volume . . . . . . . . . . . . 3.26 


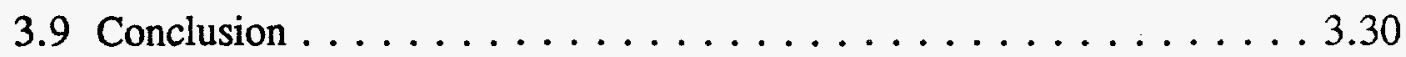

4.0

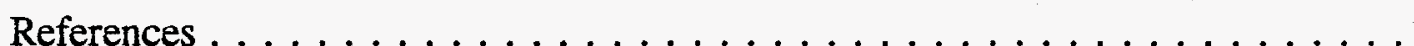

Appendix A Results from the Tank B-111 Sludge Washing and Caustic Leaching Test Appendix B Results from the Tank BX-107 Sludge Washing and Caustic Leaching Test Appendix C Results from the Tank C-103 Sludge Washing and Caustic Leaching Test Appendix D Results from the Tank S-104 Sludge Washing and Caustic Leaching Test Appendix E Results from the Tank SY-103 Sludge Washing and Caustic Leaching Test Appendix F Results from the Tank T-104 Sludge Washing and Caustic Leaching Test Appendix G Results from the Tank T-111 Sludge Washing and Caustic Leaching Test 


\section{Figures}

Figure 2.1. Titration of the First Caustic Leach Solution from the S-104 Sludge Washing and Caustic Leaching Test. (a) Titration curve: vertical line indicates the first equivalence point. (b) Gran plot. . . . . . . . 2.7

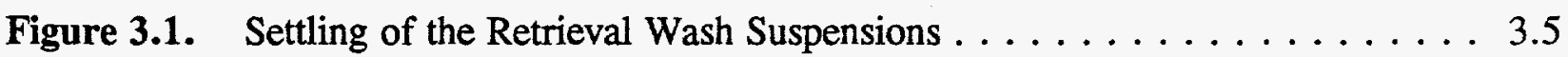

Figure 3.2. Properties of the Settled and Centrifuged Solids After the Retrieval

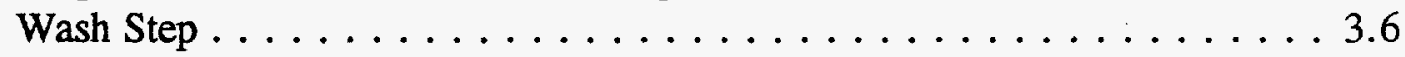

Figure 3.3. Properties of the Settled and Centrifuged Solids After the First Caustic Leach Step . . . . . . . . . . . . . . . . . 3.7

Figure 3.4. Properties of the Settled and Centrifuged Solids After the Second Caustic Leach Step . . . . . . . . . . . . . . . . . . 3.8

Figure 3.5. Observed Aluminum Dissolution vs. Baseline Assumption . . . . . . . . . 3.19

Figure 3.6. Observed Phosphorus Removal Compared to the Unleachable Alkaline Earth Phosphate Hypothesis. . . . . . . . . . . . . 3.23

Figure A.1. Schematic of the B-111 Sludge Washing and Caustic Leaching Test . . . . A.1

Figure A.2. Particle-Size Data for Untreated B-111 Sludge: a) Probability-Number Density Graph, b) Probability-Volume Density Graph, c) ProbabilityNumber Distribution Graph, and d) Probability-Volume Distribution Graph . . . . . . . . . . . . . . . . . .

Figure A.3. Particle-Size Data for Treated B-111 Sludge: a) Probability-Number Density Graph, b) Probability-Volume Density Graph, c) ProbabilityNumber Distribution Graph, and d) Probability-Volume Distribution Graph . . . . . . . . . . . . . . . . . . . A.10

Figure B.1. Schematic of the BX-107 Sludge Washing and Caustic Leaching Test . . . B.1

Figure B.2. Particle-Size Data for Untreated BX-107 Sludge: a) Probability-Number Density Graph, b) Probability-Volume Density Graph, c) ProbabilityNumber Distribution Graph, and d) Probability-Volume Distribution

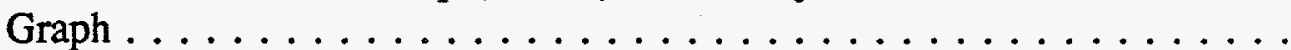


Figure B.3. Particle-Size Data for Treated BX-107 Sludge: a) Probability-Number Density Graph, b) Probability-Volume Density Graph, c) ProbabilityNumber Distribution Graph, and d) Probability-Volume Distribution

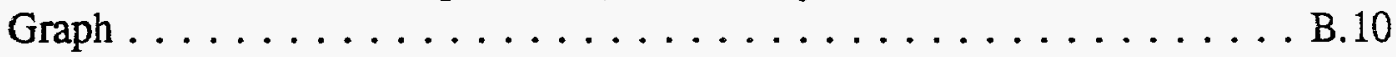

Figure C.1. Schematic of the C-103 Sludge Washing and Caustic Leaching Test . . . . C.1

Figure C.2. Particle-Size Data for Untreated C-103 Sludge: a) Probability-Number Density Graph, b) Probability-Volume Density Graph, c) ProbabilityNumber Distribution Graph, and d) Probability-Volume Distribution

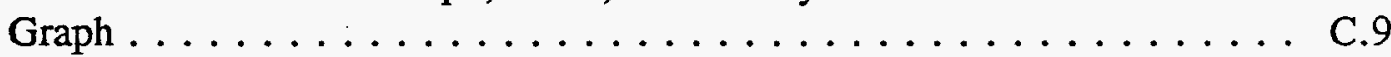

Figure C.3. Particle-Size Data for Treated C-103 Sludge: a) Probability-Number Density Graph, b) Probability-Volume Density Graph, c) ProbabilityNumber Distribution Graph, and d) Probability-Volume Distribution Graph . . . . . . . . . . . . . . . . . . 10

Figure D.1. Schematic of the S-104 Sludge Washing and Caustic Leaching Test . . . . D.1

Figure D.2. Particle-Size Data for Untreated S-104 Sludge: a) Probability-Number Density Graph, b) Probability-Volume Density Graph, c) ProbabilityNumber Distribution Graph, and d) Probability-Volume Distribution

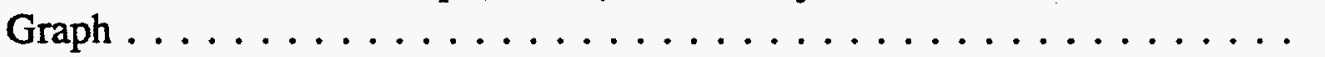

Figure D.3 - Particle-Size Data for Treated S-104 Sludge: a) Probability-Number Density Graph, b) Probability-Volume Density Graph, c) ProbabilityNumber Distribution Graph, and d) Probability-Volume Distribution Graph . . . . . . . . . . . . . . 10

Figure E.1. Schematic of the SY-103 Sludge Washing and Caustic Leaching Test . . . E.1

Figure E.2. Particle-Size Data for Untreated SY-103 Sludge: a) Probability-Number Density Graph, b) Probability-Volume Density Graph, c) ProbabilityNumber Distribution Graph, and d) Probability-Volume Distribution Graph . . . . . . . . . . . . . . . . . . . .

Figure E.3 Particle-Size Data for Treated SY-103 Sludge: a) Probability-Number Density Graph, b) Probability-Volume Density Graph, c) ProbabilityNumber Distribution Graph, and d) Probability-Volume Distribution Graph . . . . . . . . . . . . . . . . . E.10

Figure F.1. Schematic of the T-104 Sludge Washing and Caustic Leaching Test . . . . F.1 
Figure F.2. Particle-Size Data for Untreated T-104 Sludge: a) Probability-Number Density Graph, b) Probability-Volume Density Graph, c) ProbabilityNumber Distribution Graph, and d) Probability-Volume Distribution Graph . . . . . . . . . . . . . . . . . . F.9

Figure F.3. Particle-Size Data for Treated T-104 Sludge: a) Probability-Number Density Graph, b) Probability-Volume Density Graph, c) ProbabilityNumber Distribution Graph, and d) Probability-Volume Distribution Graph ............................ F.10

Figure G.1. Schematic of the T-111 Sludge Washing and Caustic Leaching Test . . . . G.1

Figure G.2. Particle-Size Data for Untreated T-111 Sludge: a) Probability-Number Density Graph, b) Probability-Volume Density Graph, c) ProbabilityNumber Distribution Graph, and d) Probability-Volume Distribution Graph ........................... G.9

Figure G.3. Particle-Size Data for Treated T-111 Sludge: a) Probability-Number Density Graph, b) Probability-Volume Density Graph, c) ProbabilityNumber Distribution Graph, and d) Probability-Volume Distribution Graph . . . . . . . . . . . . . . . . . . . . G.10 


\section{Tables}

Table S.1. Summary of Sludge Components Removed by Sludge

Washing and Caustic Leaching . . . . . . . . . . . . . . v

Table 1.1. Primary and Secondary Waste Types Stored

in the Tanks Investigated $\ldots \ldots \ldots \ldots \ldots \ldots \ldots \ldots \ldots . \ldots \ldots$

Table 2.1. Description of the Tank Samples Used . . . . . . . . . . . . . . 2.1

Table 2.2. Comparison of Free Hydroxide Ion Concentrations

Determined by Gran Plot Method and by First Equivalence

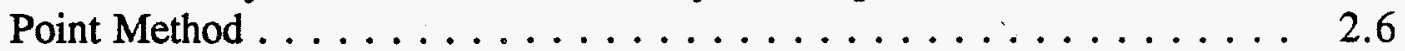

Table 3.1. Summary of General Sludge Characteristics During

Sludge Washing and Caustic Leaching . . . . . . . . . . . . 3.2

Table 3.2. Number Distribution Summary for Particle-Size Analyses

of Sludge Composites . . . . . . . . . . . . . . . . . . 3.10

Table 3.3. Volume Distribution Summary for Particle-Size Analyses

of Sludge Composites . . . . . . . . . . . . . . . . . 3.11

Table 3.4. Summary of the Effectiveness of Sludge Washing and

Caustic Leaching in Removing Key Nonradioactive Components . . . . . 3.13

Table 3.5. Summary of Phosphate and Sulfate Removal by

Sludge Washing and Caustic Leaching . . . . . . . . . . . . 3.14

Table 3.6. Summary of Phosphate and Phosphorus Concentrations

in Treated vs. Untreated Sludges . . . . . . . . . . . . 3.16

Table 3.7. Summary of Radionuclide Removal by Sludge Washing and Caustic Leaching . . . . . . . . . . . . . . .

Table 3.8. Aluminum and Silicon Molar Concentrations in Treated Sludges . . . . . 3.21

Table 3.9. Water Insoluble Phosphorus Removed by Caustic Leaching . . . . . . . 3.22 
Table 3.10. Calcium and Phosphorus Concentrations in Treated Sludges . . . . . . 3.25

Table 3.11. Comparison of Sludge Washing and Caustic Leaching Results

From Tanks In the Same SORWT Groups . . . . . . . . . . . . 3.27

Table 3.12. Impact of Sludge Washing and Caustic Leaching on

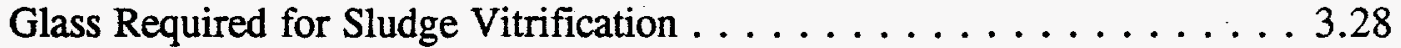

Table A.1. Concentrations of the Nonradioactive Sludge Components

in the Various Process Solutions From the B-111 Test . . . . . . . . . A.3

Table A.2. Concentrations of the Nonradioactive Sludge Components

in the Leached Sludge From the B-111 Test . . . . . . . . . . . . . A.4

Table A.3. Distribution of the Nonradioactive Sludge Components

Between the Various Process Streams From the B-111 Test . . . . . . . A.5

Table A.4. Mass Balance for Nonradioactive Sludge

Components From the B-111 Test . . . . . . . . . . . A.6

Table A.5. Concentrations of the Radioactive Sludge Components

in the Various Process Streams From the B-111 Test . . . . . . . A. 7

Table A.6. Distribution of the Radioactive Sludge Components

Between the Various Process Streams From the B-111 Test . . . . . . . A.8

Table A.7. Mass Balance for Radioactive Sludge

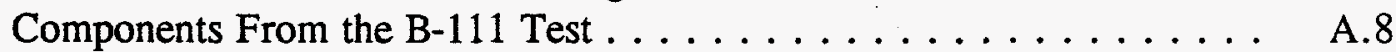

Table B.1. Concentrations of the Nonradioactive Sludge Components in the Various Process Solutions From the BX-107 Test . . . . . . . . . B.3

Table B.2. Concentrations of the Nonradioactive Sludge Components in the Leached Sludge From the BX-107 Test . . . . . . . . . . . . B.4

Table B.3. Distribution of the Nonradioactive Sludge Components

Between the Various Process Streams From the BX-107 Test . . . . . . B.5

Table B.4. Mass Balance for Nonradioactive Sludge Components

From the BX-107 Test . . . . . . . . . . . . . . . . . . . . . B.6

Table B.5. Concentrations of the Radioactive Sludge Components in the Various Process Streams From the BX-107 Test . . . . . . . B. B.7 
Table B.6. Distribution of the Radioactive Sludge Components

Between the Various Process Streams From the BX-107 Test . . . . . . B.8

Table B.7. Mass Balance for Radioactive Sludge Components

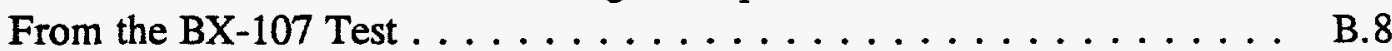

Table C.1. Concentrations of the Nonradioactive Sludge Components

in the Various Process Solutions From the C-103 Test . . . . . . . . C.3

Table C.2. Concentrations of the Nonradioactive Sludge Components

in the Leached Sludge From the C-103 Test . . . . . . . . . . . C.4

Table C.3. Distribution of the Nonradioactive Sludge Components

Between the Various Process Streams From the C-103 Test . . . . . . . C.5

Table C.4. Mass Balance for Nonradioactive Sludge Components

From the $\mathrm{C}-103$ Test . . . . . . . . . . . . . . . . C.6

Table C.5. Concentrations of the Radioactive Sludge Components

in the Various Process Streams From the C-103 Test . . . . . . . . . C.7

Table C.6. Distribution of the Radioactive Sludge Components

Between the Various Process Streams From the C-103 Test . . . . . . C. 8

Table C.7. Mass Balance for Radioactive Sludge Components

From the $\mathrm{C}-103$ Test . . . . . . . . . . . . . . . C.8

Table D.1. Concentrations of the Nonradioactive Sludge Components

in the Various Process Solutions From the S-104 Test . . . . . . . . . . D.3

Table D.2. Concentrations of the Nonradioactive Sludge Components

in the Leached Sludge From the S-104 Test . . . . . . . . . . . . . D.4

Table D.3. Distribution of the Nonradioactive Sludge Components

Between the Various Process Streams From the S-104 Test . . . . . . D. D

Table D.4. Mass Balance for Nonradioactive Sludge Components

From the S-104 Test . . . . . . . . . . . . . . . . . D.6

Table D.5. Concentrations of the Radioactive Sludge Components

in the Various Process Streams From the S-104 Test . . . . . . . . . . D.7 
Table D.6. Distribution of the Radioactive Sludge Components

Between the Various Process Streams From the S-104 Test . . . . . . D.8

Table D.7. Mass Balance for Radioactive Sludge Components

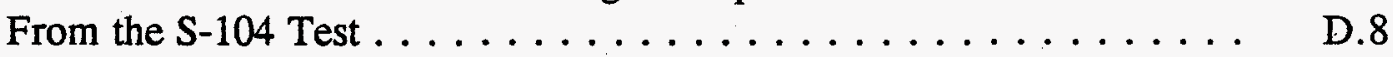

Table E.1. Concentrations of the Nonradioactive Sludge Components

in the Various Process Solutions From the SY-103 Test . . . . . . . . E. E.

Table E.2. Concentrations of the Nonradioactive Sludge Components

in the Leached Sludge From the SY-103 Test . . . . . . . . . . . . E.4

Table E.3. Distribution of the Nonradioactive Sludge Components

Between the Various Process Streams From the SY-103 Test . . . . . E E.5

Table E.4. Mass Balance for Nonradioactive Sludge Components

From the SY-103 Test . . . . . . . . . . . . . . . . . . E.6

Table E.5. Concentrations of the Radioactive Sludge Components

in the Various Process Streams From the SY-103 Test . . . . . . . . . E.7

Table E.6. Distribution of the Radioactive Sludge Components

Between the Various Process Streams From the SY-103 Test . . . . . . E.8

Table E.7. Mass Balance for Radioactive Sludge Components

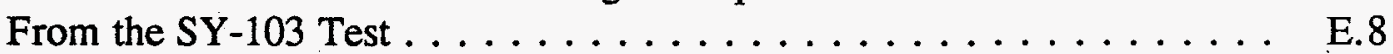

Table F.1. Concentrations of the Nonradioactive Sludge Components

in the Various Process Solutions From the T-104 Test . . . . . . . . . F.3

Table F.2. Concentrations of the Nonradioactive Sludge Components

in the Leached Sludge From the T-104 Test . . . . . . . . . . . . . F.4

Table F.3. Distribution of the Nonradioactive Sludge Components

Between the Various Process Streams From the T-104 Test . . . . . . . F.5

Table F.4. Mass Balance for Nonradioactive Sludge Components

From the T-104 Test . . . . . . . . . . . . . . . . F.6

Table F.5. Concentrations of the Radioactive Sludge Components

in the Various Process Streams From the T-104 Test . . . . . . . . . F F.7 
Table F.6. Distribution of the Radioactive Sludge Components

Between the Various Process Streams From the T-104 Test . . . . . . . F.8

Table F.7. Mass Balance for Radioactive Sludge Components

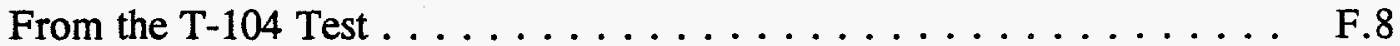

Table G.1. Concentrations of the Nonradioactive Sludge Components

in the Various Processs Solutions From the T-111 Test . . . . . . . . . G.3

Table G.2. Concentrations of the Nonradioactive Sludge Components

in the Leached Sludge From the T-111 Test . . . . . . . . . . . . . . G.4

Table G.3. Distribution of the Nonradioactive Sludge Components

Between the Various Process Streams From the T-111 Test . . . . . . . . G.5

Table G.4. Mass Balance for Nonradioactive Sludge Components

From the $\mathrm{T}-111$ Test . . . . . . . . . . . . . . . . . . . . G.6

Table G.5. Concentrations of the Radioactive Sludge Components

in the Various Process Streams From the T-111 Test . . . . . . . . . . G.7

Table G.6. Distribution of the Radioactive Sludge Components

Between the Various Process Streams From the T-111 Test . . . . . . . . G.8

Table G.7. Mass Balance for Radioactive Sludge Components

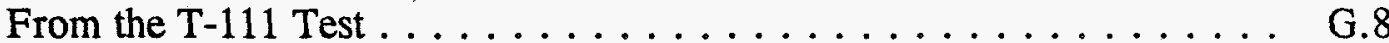




\subsection{Introduction}

During the past few years, the primary mission at the U.S. Department of Energy's Hanford Site has changed from producing plutonium to environmental restoration. Large volumes of high-level radioactive wastes (HLW), generated during past $\mathrm{Pu}$ production and other operations, are stored in underground tanks on site. The current plan for remediating the Hanford tank farms consists of waste retrieval, pretreatment, treatment (immobilization), and disposal. The HLW will be immobilized in a borosilicate glass matrix; the resulting glass canisters will then be disposed of in a geologic repository. Because of the expected high cost of HLW immobilization and disposal, pretreatment processes will be implemented to reduce the volume of borosilicate glass produced in processing the tank wastes.

This document describes sludge washing and caustic leaching tests conducted in FY 1995 at the Pacific Northwest Laboratory (PNL) ${ }^{(a)}$ at the request of Westinghouse Hanford Company. These tests were performed using sludges from seven Hanford waste tanks-B-111, BX-107, C-103, S-104, SY-103, T-104, and T-111. The primary and secondary types of waste stored in each of these tanks are given in Table 1.1. The data collected in this effort will be used to support the March 1998 Tri-Party Agreement decision on the extent of pretreatment to be performed on the Hanford tank sludges (Ecology, EPA, and DOE 1994).

According to the baseline sludge pretreatment flowsheet, the sludge will be retrieved from the tanks by sluicing and pumping with inhibited water (0.01 M NaOH/0.01 $\left.\mathrm{M} \mathrm{NaNO}_{2}\right)$, leached with caustic $(3 \mathrm{M} \mathrm{NaOH})$, then washed with inhibited water to remove the added $\mathrm{NaOH}$ and the components dissolved during the caustic leaching step. The retrieval, leachate, and wash solutions will be combined and processed to remove ${ }^{137} \mathrm{Cs}$ (and possibly other radionuclides). The decontaminated solution will then be routed to the low-level waste (LLW) stream, where it will be immobilized in a glass matrix. The leached solids, which will contain the transuranic (TRU) elements and ${ }^{90} \mathrm{Sr}$, will be handled as HLW (Orme 1994). 
Table 1.1. Primary and Secondary Waste Types Stored in the Tanks Investigated ${ }^{(a)}$

\begin{tabular}{|c|c|c|}
\hline Tank & Primary Waste & Secondary Waste \\
\hline B-111 & $2 \mathrm{C}$ & $5-6$ \\
\hline BX-107 & $1 \mathrm{C}$ & TBP \\
\hline$C-103$ & SRS & SR-WASH \\
\hline S-104 & $\mathbf{R}$ & (b) \\
\hline SY-103 & $\mathrm{CC}$ & (b) \\
\hline $\mathrm{T}-104$ & $1 \mathrm{C}$ & (b) \\
\hline $\mathrm{T}-111$ & $2 \mathrm{C}$ & 224 \\
\hline
\end{tabular}

(a) The waste types are defined as follows (Hill, Anderson, and Simpson 1995).

CC Complexant concentrate

$\mathrm{R} \quad$ Reduction oxidation (REDOX) process high-level waste

SRS Sludge feed for the Sr extraction process at B Plant

SR-WASH Particulates from Sr wash of plutonium uranium extraction (PUREX) wastes in AR Vault

TBP Waste from the tributyl phosphate (TBP) uranium extraction process at U Plant

1C First-cycle decontamination waste from the bismuthphosphate process

2C Second-cycle decontamination waste from the bismuth-phosphate process

224 Lanthanum fluoride decontamination waste from the bismuth-phosphate process

5-6 High-level waste from Tank 5-6 at B Plant

(b) No major secondary waste type.

Caustic leaching is expected to remove a large fraction of the $\mathrm{Al}$, which is present in large quantities in Hanford tank sludges (Weber 1982). A significant portion of the $P$ is also expected to be removed from the sludge by metathesis of water-insoluble metal phosphate salts to insoluble hydroxide salts and soluble $\mathrm{Na}_{3} \mathrm{PO}_{4}$. Removing $\mathrm{Al}$ and $\mathrm{P}$ from the sludge solids could have a large impact in reducing the volume of HLW glass produced during tank waste disposal operations. 
Previous studies on leaching sludges with highly caustic solutions (both in the presence or absence of other $\mathrm{Cr}$-solubilizing agents) suggest that $\mathrm{Cr}$ might also be removed from the sludges (Lumetta et al. 1994; Lumetta and Swanson 1993b). Enhanced Cr dissolution has been observed at highly caustic vs. mildly basic solutions and may be due to the increased solubility of $\mathrm{Cr}(\mathrm{III})$ at high-hydroxide concentrations (Rai, Sass, and Moore 1987). For certain sludges, leaching such key components should result in a greatly decreased volume of HLW glass produced without resorting to more aggressive dissolution and separation methods (Straalsund et al. 1992). For example, removal of $\mathrm{Cr}$ from Plutonium Finishing Plant (PFP) sludge alone is estimated to decrease the number of glass canisters from 2500 for washed-only sludge to 500 for Cr-free washed sludge (Lumetta, Swanson, and Barker 1995). ${ }^{\text {(a) }}$

Previous studies of washing and caustic leaching of Hanford tank sludges have been reported (Lumetta and Rapko 1994; Lumetta, Rapko, and Colton 1994). Although the previous tests were not performed under conditions identical to those of the current baseline flowsheet, the results indicated $83 \%$ removal of $\mathrm{Al}, 62 \%$ removal of $\mathrm{Cr}$, and $89 \%$ removal of $P$ from the total quantities present in the five tanks investigated. 


\subsection{Experimental}

The materials and methods used in the sludge washing and caustic leaching screening tests are discussed in this section.

\subsection{Materials}

Sludge washing and caustic leaching screening tests were performed on sludges from seven Hanford tanks. The seven tanks are listed in Table 2.1 along with the details of the individual samples investigated.

Table 2.1. Description of Tank Sludge Samples Used

\begin{tabular}{|c|c|c|}
\hline Tank & Core Number & Description \\
\hline B-111 & 29 and 30 & $\begin{array}{l}\text { Composite sample comprised of } 2.65 \mathrm{~g} \text { of } \\
\text { Core } 29 \text { composite } 1 \text { \{Analytical Laboratory } \\
\text { Operations (ALO) Number } 93-04314\} \text {, (a) } \\
1.96 \mathrm{~g} \text { of Core } 29 \text { composite } 2 \text { (ALO } \\
\text { Number } 93-04315 \text { ), } 2.64 \mathrm{~g} \text { of Core } 30 \\
\text { composite } 1 \text { (ALO Number } 93-04322 \text { ), and } \\
2.57 \mathrm{~g} \text { of Core } 30 \text { composite } 2 \text { (ALO } \\
\text { Number } 93-04323 \text { ) }\end{array}$ \\
\hline BX-107 & 41 & $\begin{array}{l}\text { Composite from Core } 41 \text { (222-S Jar } \\
\text { Number J941)(b) }\end{array}$ \\
\hline C-103 & 63 & $\begin{array}{l}\text { Composite sample of segments } 2-4 \text { from } \\
\text { core } 63 \text { ( } 222-S \text { Jar Number } 6770)\end{array}$ \\
\hline S-104 & 43 & $\begin{array}{l}\text { Composite of segments } 4 \text { and } 5 \text { from Core } \\
43 \text { (222-S Jar Number } 6588 \text { ) }\end{array}$ \\
\hline SY-103 & 62 & $\begin{array}{l}\text { Composite of segments } 10 \text { through } 14 \text { from } \\
\text { Core } 62 \text { (222-S Jar Number } 6590)\end{array}$ \\
\hline T-104 & 46 & $\begin{array}{l}\text { Composite of segments } 2,3 \text {, and } 4 \text { from } \\
\text { Core } 46 \text { (222-S Jar Number } 6555)\end{array}$ \\
\hline $\mathrm{T}-111$ & 33 & $\begin{array}{l}\text { Composite of segments } 1 \text { and } 3 \text { from Core } \\
33 \text { (222-S Jar Number } 6591 \text { ) }\end{array}$ \\
\hline
\end{tabular}

(a) The ALO Number is a unique identifying number used by the PNL Analytical Chemistry Laboratory to track samples.

(b) Identifying number used at the Westinghouse Hanford Company (WHC) 222-S laboratory for tracking samples. 
Solutions were prepared using reagent grade $\mathrm{NaOH}, \mathrm{NaNO}_{3}$, and $\mathrm{NaNO}_{2}$. The concentrations of the $\mathrm{NaOH}$ solutions were confirmed by titration with standard $\mathrm{HCl}$.

\subsection{Sludge Washing and Caustic Leaching Procedure}

The same general procedure was used for each sludge washing and caustic leaching test; specific details for each test are given in schematic figures in the appendices (Figures A.1,

B.1, C.1, D.1, E.1, F.1, and G.1). The procedure consisted of the following steps.

1. A portion of the sludge was placed in a high-density polyethylene (HDPE) or polymethylpentene bottle.

2. The sludge was slurried in water ( $4 \mathrm{~g}$ water/g sludge); then four aliquots of the slurry were removed.

3. One of the aliquots was dried to a constant weight at $80^{\circ} \mathrm{C}$; this dried aliquot was submitted for analysis.

4. Two of the aliquots were saved. One was used for particle-size measurements; the second was dried and used for microscopy studies.

5. The fourth aliquot was washed with three $5-\mathrm{mL}$ portions of $0.01 \mathrm{M} \mathrm{NaOH} / 0.01 \mathrm{M}$ $\mathrm{NaNO}_{2}$ at room temperature, and was then dried to a constant weight at $80^{\circ} \mathrm{C}$. This weight was assumed to represent the water-insoluble solids in the sludge, and was used to determine the weight percent of such solids in the sludge sample.

6. The weight percent of water-insoluble solids determined in step 5 was used to determine the total volume of "retrieval" solution needed to yield a slurry containing $2.3 \mathrm{wt} \%$ solids. ${ }^{(a)}$ Water, $\mathrm{NaOH}$, and $\mathrm{NaNO}_{2}$ were added to the sludge slurry to give the appropriate volume of $0.01 \mathrm{M} \mathrm{NaOH} / 0.01 \mathrm{M} \mathrm{NaNO}_{2}$ retrieval solution. The resulting mixture was stirred and heated at $100^{\circ} \mathrm{C}$ for $1 \mathrm{~h}$.

7. After cooling to room temperature, mixing was stopped, and the solids were allowed to settle under the force of gravity.

(a) The first step in the process was designed to mimic the retrieval process outlined in the baseline sludge treatment flowsheet (Orme 1994). 
8. Once the sludge had stopped settling, the mixture was centrifuged, and the solution was decanted. Hereafter, this solution will be referred to as the "retrieval wash" solution.

9. The weight percent of water-insoluble solids determined in step 5 was used to determine the total volume of caustic leach solution needed to yield a slurry containing $8 \mathrm{wt} \%$ solids (assuming that $30 \%$ of the water-insoluble solids dissolve in the caustic leaching step).

10. At this point, the sludge was transferred to a smaller container that was more consistent with the volume of the caustic leach solution to be used. Typically this smaller container was a 20 -mL HDPE vial or a $30-\mathrm{mL}$ polypropylene Oak Ridge-type centrifuge tube. The sludge was transferred using portions of the retrieval wash solution that was collected in Step 8. Upon quantitative transfer of the sludge, the slurry was centrifuged; then the supernatant solution was decanted and combined with the rest of the retrieval wash solution.

11. Water and $10 \mathrm{M} \mathrm{NaOH}$ were added to the sludge to give a caustic leach mixture with the volume determined in Step 9, and an initial hydroxide concentration of nominally $3.2 \mathrm{M}$. The resulting mixture was stirred and heated at $100^{\circ} \mathrm{C}$ for $5 \mathrm{~h}$.

12. After cooling to room temperature, mixing was stopped, and the solids were allowed to settle under the force of gravity.

13. Once the sludge had stopped settling, the mixture was centrifuged, and the solution was decanted. Hereafter, this solution will be referred to as the first caustic leach solution.

14. A second caustic leach step was performed by adding enough $3 \mathrm{M} \mathrm{NaOH}$ to give a total volume equal to that determined in Step 9. Again, the leach mixture was stirred and heated at $100^{\circ} \mathrm{C}$ for $5 \mathrm{~h}$.

15. After cooling to room temperature, mixing was stopped, and the solids were allowed to settle under the force of gravity.

16. Once the sludge had stopped settling, the mixture was centrifuged, and the solution was decanted. Hereafter, this solution will be referred to as the second caustic leach solution.

17. The leached sludge was successively washed with three portions of $0.01 \mathrm{M} \mathrm{NaOH} /$ $0.01 \mathrm{M} \mathrm{NaNO}_{2}$; the volume of each portion of wash solution was equal to the volume of the second caustic leach solution decanted in Step 16. For the first two portions, mixing was stopped after mixing for at least $0.5 \mathrm{~h}$ at room temperature, and the solids were allowed to settle under the force of gravity. In the case of the third wash, two aliquots of the suspension were removed before the solids were allowed to settle. One aliquot was saved for a particle-size measurement; the second was dried and used for microscopy 
studies. In each case, after gravitiy settling the mixture was centrifuged then the wash liquor was decanted.

18. Finally, the remaining residue was dried to a constant weight at $80^{\circ} \mathrm{C}$.

Some of the weights measured in the course of the tests had inconsistencies. This was especially true for the C-103 test, which was performed in a hot cell due to the high ${ }^{90} \mathrm{Sr}$ content of that material. For example, when a portion of the slurried sludge (C103-2B in Figure C.1) was dried to determine the wt\% solids in the sludge, the amount of dry sludge solids $(0.54 \mathrm{~g})$ was greater than the amount of sludge expected to be in the slurry $(0.47 \mathrm{~g})$. This might have resulted from inadequate stirring of the slurry during sampling; that is, if the sludge solids were not homogeneously dispersed in the slurry, the portion withdrawn in C103$2 \mathrm{~B}$ could have contained $>0.47 \mathrm{~g}$. During an earlier test with the same $\mathrm{C}-103$ sludge sample, the sludge was found to consist of 43 wt\% solids. ${ }^{(a)}$ Using the latter value, the dry weight of the solids leached was determined to be $6.3 \mathrm{~g}$, which is the value given in Figure C.1.

The amount of retrieval wash solution obtained for the C-103 test was also inconsistent with the amount of materials added. Correcting for the mass of samples taken and the mass lost due to evaporation during heating, the mass of the retrieval wash slurry was $99.8 \mathrm{~g}$. Yet only a total of $87.9 \mathrm{~g}$ of material $(76.9 \mathrm{~g}$ of retrieval wash solution and $11.0 \mathrm{~g}$ of centrifuged solids) was recovered. The reason for this discrepency is unknown.

\subsection{Analytical Methods}

Portions of the sludges were analyzed before and after the sludge washing/caustic leaching treatment. The solid samples were solubilized for analysis by a well established $\mathrm{KOH}$ fusion method. ${ }^{(b)}$ Samples of the retrieval wash, the first and second caustic leach, and the

(a) This earlier test was aborted during the first caustic leaching step due to a suspected loss of containment of the vial being used.

(b) Analytical Chemistry Laboratory Department. Analytical Chemistry Laboratory (ACL) Procedure Compendium. PNL-MA-599. Pacific Northwest Laboratory, Richland, Washington. 
final wash solutions were analyzed after acidification with $\mathrm{HNO}_{3}$. The major metallic elements ( $\mathrm{Al}, \mathrm{Bi}, \mathrm{Cr}, \mathrm{Fe}, \mathrm{Na}$, etc.) as well as $\mathrm{P}$ and $\mathrm{Si}$ were determined by inductively coupled plasma/atomic emission spectroscopy (ICP/AES). Ion chromatography (IC) was performed to determine the anions present. Alpha spectroscopy was used to determine the transuranic elements present, and gamma spectroscopy was used to measure the gammaemitting radionuclides such as ${ }^{137} \mathrm{Cs}$. Uranium concentrations were determined by laser fluorimetry. A proportional beta counter was used to determine ${ }^{90} \mathrm{Sr}$ and ${ }^{99} \mathrm{Tc}$ after chemical separation of these isotopes from the other radionuclides. Established procedures were used for all these analyses. ${ }^{(a)}$

Particle-size measurements were made using a Brinkmann Instruments Model PSA 2010, which measures particle diameter based on the time required for a fixed-velocity scanning laser beam to traverse the particle. The samples were dispersed for the measurement in $1: 1(\mathrm{v}: \mathrm{v})$ mixture of water and glycerin.

Free hydroxide concentrations in the caustic leach solutions were determined by titration with standard $\mathrm{HCl}$. The titrations were performed potentiometrically using a Mettler DL21 automatic titrator equipped with a ROSS ${ }^{\circledR}$ combination $\mathrm{pH}$ electrode (Orion Research Inc., Boston, Massachusetts). Work by others at PNL using simulated Tank SY-101 simulant indicated that the free hydroxide concentration in complex matrices can be determined by the Gran plot method. ${ }^{(a)}$ In the course of this work, it was found that a simpler way to determine the free hydroxide concentration in the sludge leach solutions was to equate the first inflection point in the titration curve to the free hydroxide concentration. The latter method assumes that hydroxide ion is the strongest base in the leach solution and thus is consumed first by the $\mathrm{HCl}$ titrant. A typical titration curve and corresponding Gran plot are given in Figure 2.1. In this example, a $0.1-\mathrm{mL}$ aliquot of the first caustic leach solution from the S-104 test was diluted with $10 \mathrm{~mL}$ of water and titrated with $0.103 \mathrm{M} \mathrm{HCl}$. The first inflection point in the titration curve was at $3.70 \mathrm{~mL}$, which corresponds to $3.8 \mathrm{M}$ free hydroxide ion. The Gran plot reveals

Karl Pool. 1994. Unpublished data. Pacific Northwest Laboratory, Richland, Washington. 
the equivalence point for free hydroxide ion to be $3.62 \mathrm{~mL}$, giving $3.7 \mathrm{M} \mathrm{OH}^{-}$. Table 2.2 presents a comparison of free hydroxide ion concentrations determined by both methods. Clearly, the two methods are essentially equivalent.

Table 2.2. Comparison of Free Hydroxide Ion Concentrations Determined by Gran Plot Method and by First Equivalence Point Method

\begin{tabular}{|c|c|c|}
\hline Solution & Gran Plot & First Inflection Point \\
\hline B-111 First Caustic Leach & 2.2 & 2.3 \\
\hline B-111 Second Caustic Leach & 4.0 & 4.3 \\
\hline BX-107 First Caustic Leach & 2.0 & 2.0 \\
\hline BX-107 Second Caustic Leach & 3.5 & 3.6 \\
\hline C-103 First Caustic Leach & 0.61 & 0.60 \\
\hline C-103 Second Caustic Leach & 1.0 & 1.0 \\
\hline S-104 First Caustic Leach & 3.7 & 3.8 \\
\hline S-104 Second Caustic Leach & 2.9 & 3.0 \\
\hline SY-103 First Caustic Leach & 2.2 & 2.2 \\
\hline SY-103 Second Caustic Leach & 2.7 & 2.8 \\
\hline T-104 First Caustic Leach & 0.32 & 0.31 \\
\hline T-104 Second Caustic Leach & 2.2 & 2.2 \\
\hline T-111 First Caustic Leach & 3.3 & 3.5 \\
\hline T-111 Second Caustic Leach & 3.2 & 3.4 \\
\hline
\end{tabular}



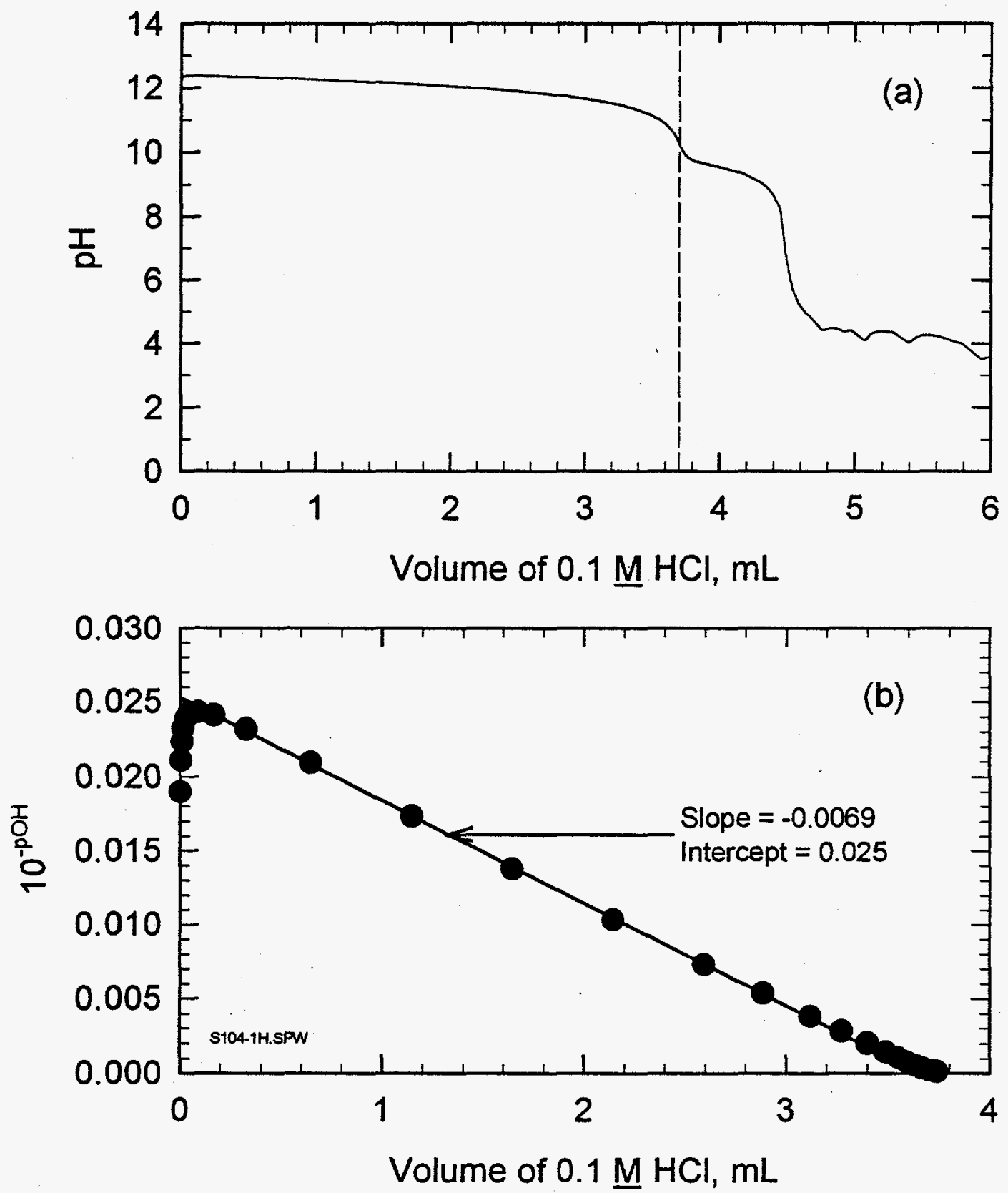

Figure 2.1. Titration of the First Caustic Leach Solution from the S-104 Sludge Washing and Caustic Leaching Test. (a) Titration curve: vertical line indicates the first equivalence point. (b) Gran plot. 


\subsection{Results and Discussion}

Data obtained from the sludge washing and caustic leaching screening tests are discussed in this section. The presentation is organized according to the type of measurements performed; that is, the results of each type of measurement or observation are discussed regarding the entire series of sludges investigated. The following subjects are covered in this section: 1) general observations, 2) settling behavior of sludge solids, 3) particle size before and after leaching, 4) behavior of nonradioactive sludge components, 5) behavior of anionic components, 6) behavior of radionuclides, 7) impacts of the data on the planning assumptions, and 8) impact of sludge washing and caustic leaching on the HLW glass volume.

\subsection{General Observations}

This section describes basic changes that occurred during the sludge washing and caustic leaching tests. Table 3.1 summarizes such features as the $\mathrm{pH}$ of the retrieval wash solutions following contact with the sludges, weight percent insoluble solids found for each sludge, and the mass loss accompanying the sludge washing and caustic leaching pretreatment tests.

A tank-by-tank comparison of any of the features described in Table 3.1 indicates considerable variability-a common theme throughout this work and one that is not unexpected given the disparate processes by which these sludges were generated. The second column reports the percentage of the sludge mass attributed to the solids present in the as-received composites (including the mass of dissolved salts in the interstitial liquid) and compares this measured value to that reported during the initial sludge characterization. The sludge samples varied from very wet materials (e.g., T-104 and T-111) to fairly dry solids (e.g., S-104). These values correlate with the general appearance of the sludges: T-104 and T-111 sludges appeared as runny slurries, while S-104 appeared as more of a thick dry paste, or even as tarlike in consistency. Agreement with the tank characterization reports for these sludges was reasonably good, and the general trend appeared to be the same in that the tank characterization data also indicate $\mathrm{T}-104$ and $\mathrm{T}-111$ sludges have the highest water contents. Reasons for the lack of close agreement where discrepancies are apparent include possible 
Table 3.1. Summary of General Sludge Characteristics During Sludge Washing and Caustic Leaching

\begin{tabular}{|c|c|c|c|c|}
\hline Tank & $\begin{array}{c}\text { Wt\% } \\
\text { Solids }^{(a)}\end{array}$ & $\begin{array}{l}\text { Wt\% Water- } \\
\text { Insoluble } \\
\text { Solids }^{(b)}\end{array}$ & $\begin{array}{l}\text { Estimated Mass } \\
\text { Loss During } \\
\text { Leaching, \% }\end{array}$ & 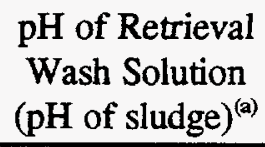 \\
\hline B-111 & $45(36)$ & 22 & 0 & $9.7(11)$ \\
\hline BX-107 & $53(43)$ & 34 & 36 & $9.8(9.7)$ \\
\hline C-103 & $42(39)$ & 31 & na & $10.2(9.8)$ \\
\hline S-104 & $87(65)$ & 49 & 33 & $12.2(13)$ \\
\hline SY-103 & 64 (na) & 11 & 56 & $13.2(\mathrm{na})$ \\
\hline $\mathrm{T}-104$ & $28(29)$ & 56 & 1 & $9.8(10)$ \\
\hline $\mathrm{T}-111$ & $22(24)$ & 62 & 10 & $11.4(10)$ \\
\hline
\end{tabular}

na $=$ data not available

(a) Values in parentheses are taken from Colton (1995), which in turn were compiled from original tank characterization data.

(b) Based on the dry weight of the sludge solids.

differences in the composite used or, more likely, some drying of the materials during storage. The latter possibility is supported by the fact that in every case except T-104 and T-107, the weight percent solids measured in this work is greater than that measured in the tank characterization work.

The third column in Table 3.1 reports the weight percent water-insoluble solids, based on the dry weight of the sludge solids. The amount of insoluble material as a portion of the total solids ranged over a factor of $~ 6$ for the sludges examined, with T-104, T-111, and S-104 having high portions of water-insoluble solids. Tank SY-103 contains complexant concentrate waste and thus would be expected to have some of the metallic elements present in a complexed water-soluble form. Indeed, the SY-103 sludge had the lowest fraction of water insoluble solids for the sludges investigated in this work.

The fourth column in Table 3.1 reports on the mass lost during the washing and caustic leaching steps. This was calculated by taking the final dried solids weight (after compensation 
for the aliquots removed for particle-size determination and microscopy) and dividing by the calculated amount of initial water-insoluble solids present. To estimate the volume of leach solution required to give $8 \mathrm{wt} \%$ solids at the end of the caustic leach step, the test procedure assumed $30 \%$ of the water-insoluble solids would be removed during the caustic leach step. Table 3.1 indicates that while $30 \%$ appears as a reasonable median value, actual mass losses ranged from $0 \%$ (T-104 and B-111) to almost $60 \%$ (SY-103). The function of the caustic leach step is both to dissolve some major nonradioactive components (primarily $\mathrm{Al}$ ), and to metathesize insoluble phosphate and sulfate salts to the corresponding insoluble hydroxides and soluble sodium phosphate and sodium sulfate. Qualitatively, the observed trends of mass loss during the caustic leach step were consistent. Sludges with relatively high amounts of Al (SY$103, \mathrm{~S}-104, \mathrm{BX}-107)$ showed the most substantial mass losses during the sludge washing and caustic leaching tests.

The final column in Table 3.1 reports the $\mathrm{pH}$ of the retrieval wash solutions, as well as the reported approximate $\mathrm{pH}$ of the sludge (Colton 1995). With $0.01 \mathrm{M} \mathrm{OH}^{-}$in the retrieval wash solutions, the initial expectation would be that the $\mathrm{pH}$ of the retrieval wash solution upon contact with the sludge solids should be a value between the sludge's reported $\mathrm{pH}$ and that of the retrieval wash solution ( $\mathrm{pH} \sim 12)$. This expectation was borne out in all cases but $\mathrm{B}-111$, where the observed $\mathrm{pH}$ of the retrieval wash solution (9.7) was much less than either the wash solution itself or the sludge. The reason for the unusual behavior for B-111 is unknown, but could be due to differences in the sample used in the previous characterization work to that used here. In all other cases, the $\mathrm{pH}$ of the retrieval wash solutions were indeed bounded by the sludge and the wash solution before sludge contact. In most cases, the sludges exhibited a substantial buffering effect as indicated by the retrieval wash solution's final $\mathrm{pH}$ being closest to the initial $\mathrm{pH}$ of the sludge, even at the relatively high volume/solids ratio of $2.3 \%$ insoluble solids used. However, for sludges T-111 and S-104 the impact of the sludge on the solution's final $\mathrm{pH}$ was markedly less. 


\subsection{Settling Behavior of the Sludge Solids}

The settling behavior of the sludge solids during the retrieval wash step is summarized in Figure 3.1. Data for six sludges, B-111, BX-107, S-104, SY-103, T-104, and T-111 are included. The sludge washing and caustic leaching test with C-103 was performed in the hot cell. Poor visibility vitiated gathering settling data for this test. As Figure 3.1 illustrates, different sludges had very different settling characteristics, ranging from the rapid settling observed with SY-103, BX-107, and T-104 sludges to the very poor settling of S-104 sludge. For T-111 sludge, an induction period was observed before the onset of rapid settling; such behavior was not observed for the other sludges investigated in this work, but has been observed in other studies (Lumetta and Swanson 1993a). In general, these sludges settled to nearly their final sludge volumes within the first few hours, S-104 being a noticeable exception.

Figures 3.2 to 3.4 summarize the extent of the solids settling (generally, after $18 \mathrm{~h}$ ), as well as the extent of solids compaction by centrifugation at up to $1700 \mathrm{G}$ for $15 \mathrm{~min}$. In selected cases, longer centrifugation times were employed with little, if any, additional decrease in the sludge height. The solids concentrations in the gravity-settled and centrifuged sludges (indicated at the bottom of the figures) were derived from the initial solids concentrations in the starting slurry (indicated in the middle of the figures) and the corresponding decrease in the solids volume (indicated at the top of figures). Figure 3.2 focuses on the final solids characteristics during the retrieval wash step. The centrifuged solids compacted to within a fairly narrow range of around $10 \%$ of the original volume of the retrieval wash slurry, giving a solids concentration of around 15 to $25 \mathrm{wt} \%$ in all cases. Very different values were found for the gravity settled solids in the retrieval wash solutions. While some sludges such as T-104 and SY-103 settled by gravity to $20 \%$ of the original volume, S104 settled by gravity to only $70 \%$ of the original volume. This led to solids loading in the settled sludge ranging from around 3 to $15 \mathrm{wt} \%$ under the conditions employed here.

Figures 3.3 and 3.4 describe the final solids characteristics in the first and second caustic leach steps, respectively. The behavior was very similar between each leach step. In all 


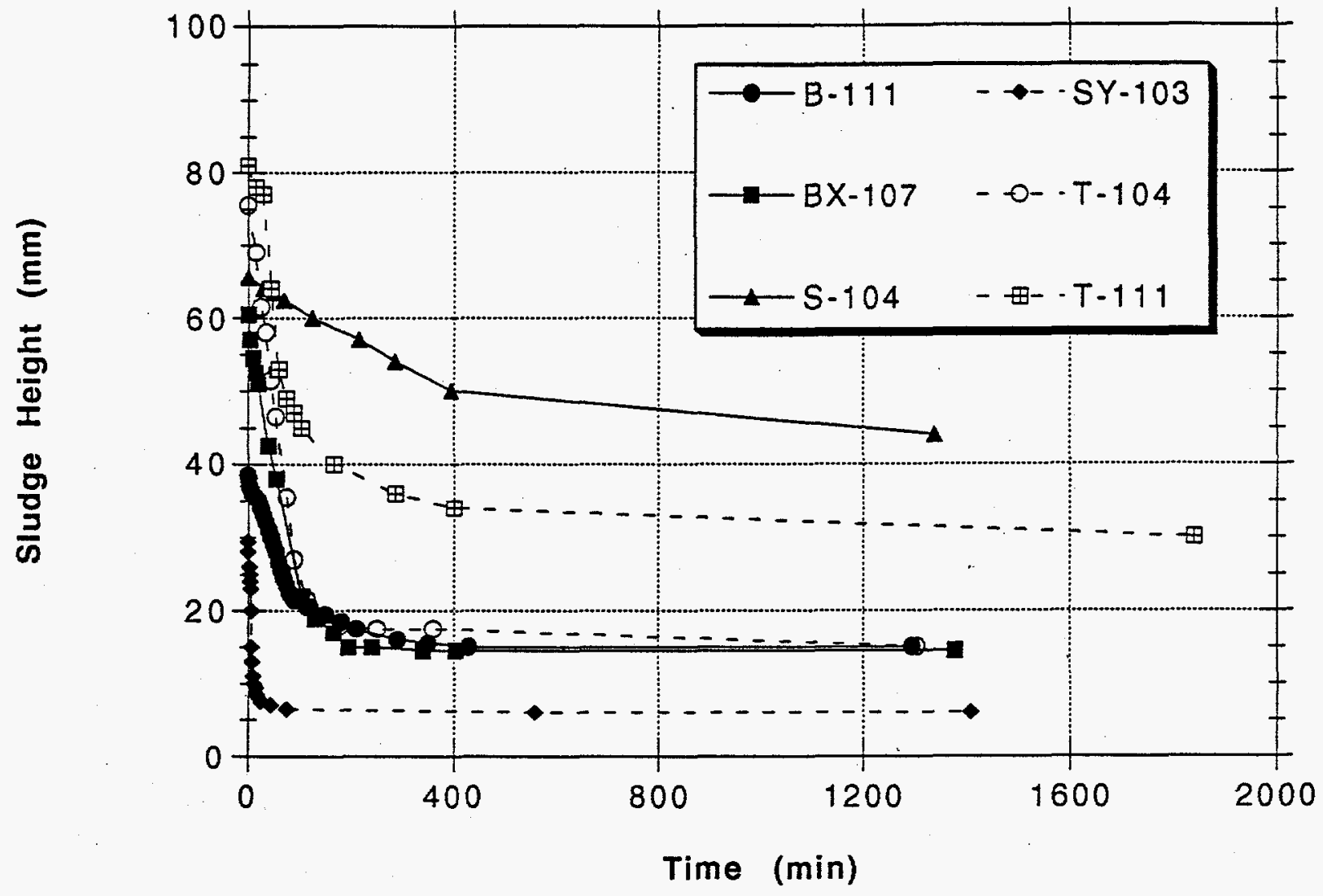

Figure 3.1. Settling of the Retrieval Wash Suspensions

cases, the solids compaction by gravity settling during the leaching step was much poorer than during the retrieval wash. Indeed, half of the sludge suspensions examined showed no clear liquid at all and the ones that did showed much less settling than in the retrieval wash step. In most cases, the solids concentrations in the centrifuged solids after the second caustic leaching step were similar to those in the centrifuged solids following the retrieval wash step. This suggests much of the settling difference observed for the retrieval wash and caustic leaching steps simply reflects the higher initial solids concentration used in the caustic leach steps. 


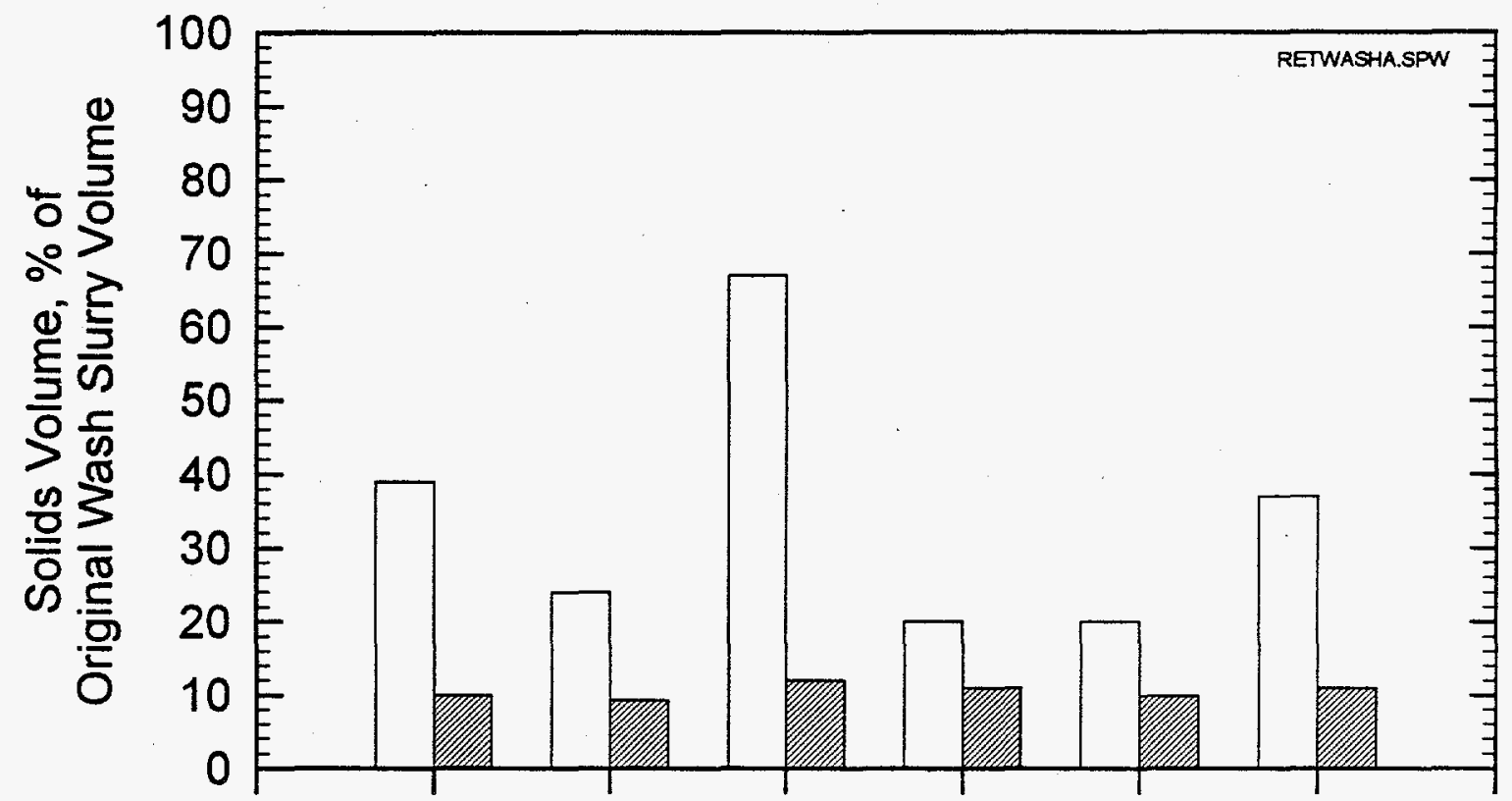

Solids Concentration

$\begin{array}{lllllll}\text { in Starting Slurry, wt\%: } & 1.9 & 2.1 & 2.2 & 1.4 & 2.0 & 2.0\end{array}$

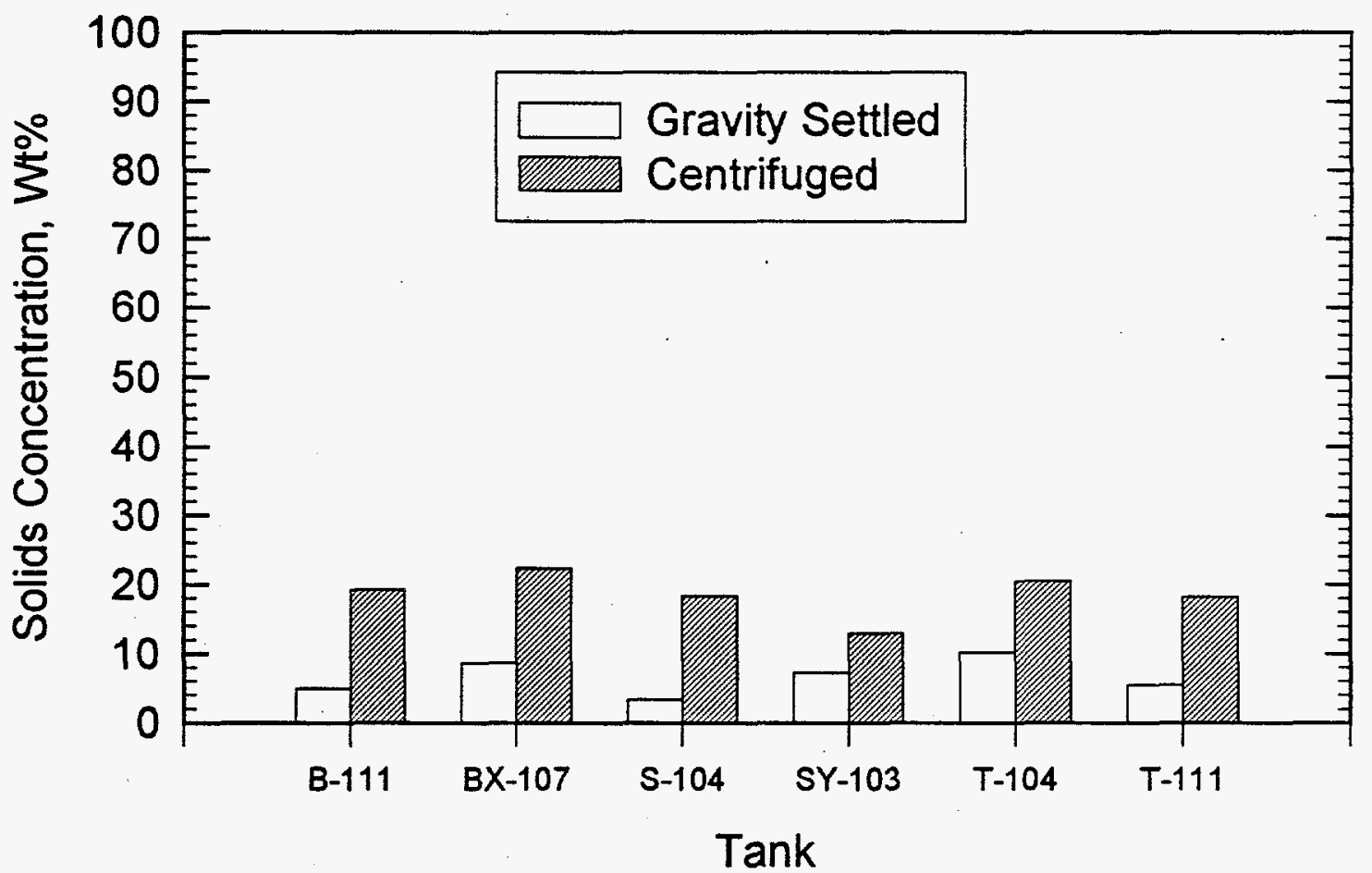

Figure 3.2. Properties of the Settled and Centrifuged Solids After the Retrieval Wash Step 


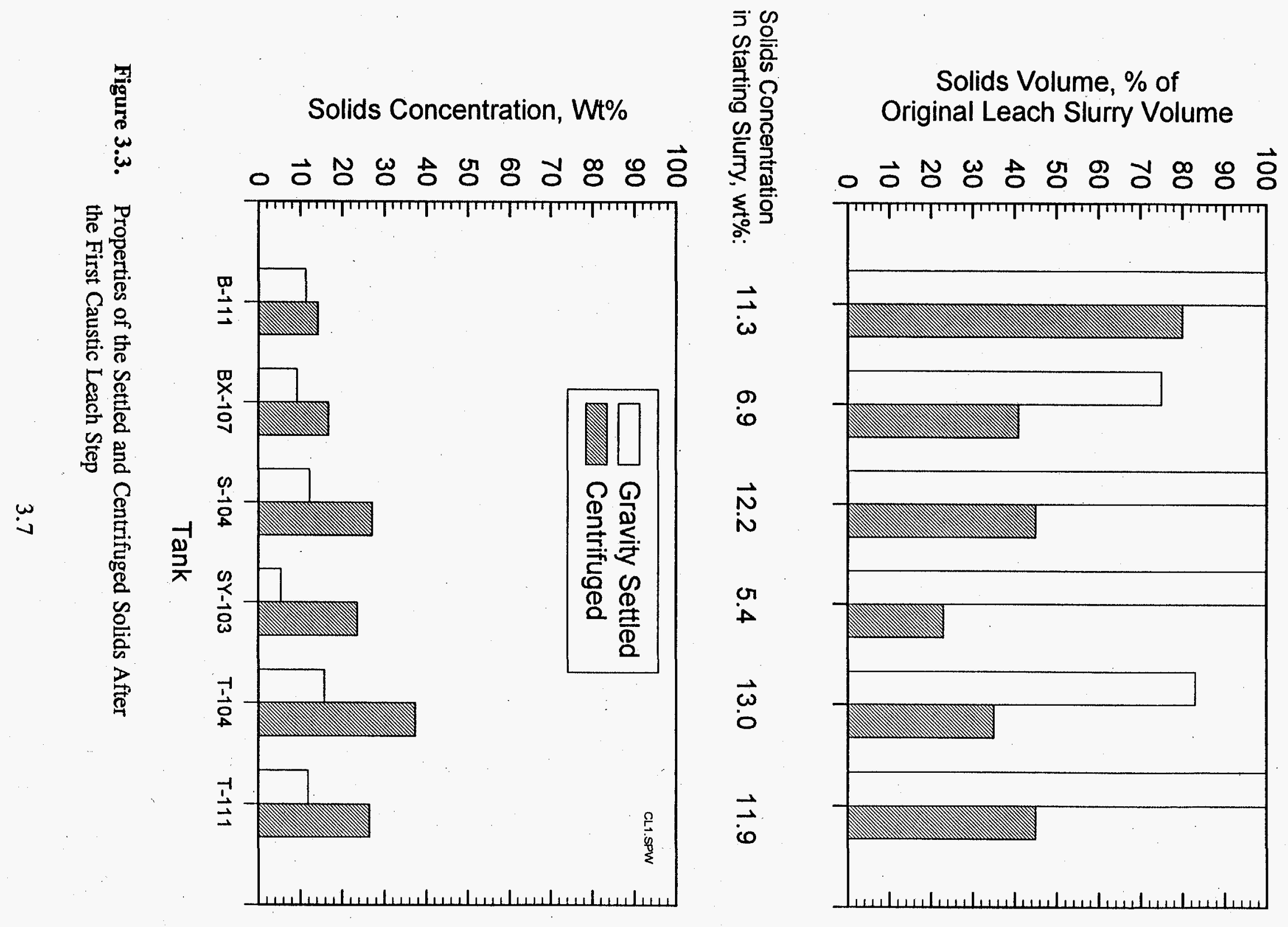




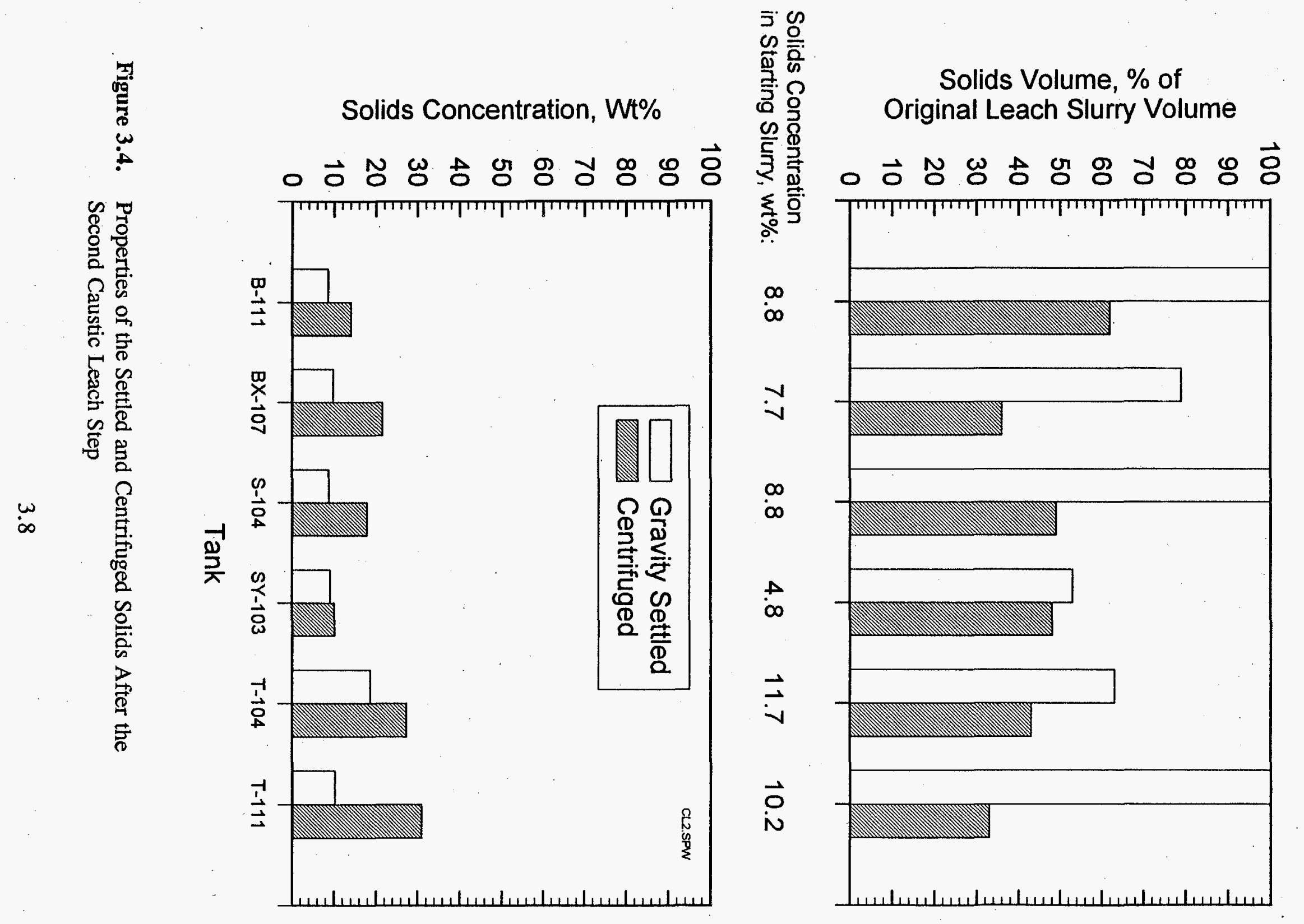




\subsection{Particle-Size Analysis of Sludges Before and After Washing and Leaching}

Particle-size distributions of the sludge solids were measured both before and after sludge washing and caustic leaching. Plots of the results, expressed as both a number and a volume percent distribution, are given in the Appendices. The samples were prepared for analysis by suspension in a 1:1 water/glycerin matrix, and it is unclear if this matrix yields an accurate measurement of the particle-size distributions that would be encountered in processing. Because of primary particle agglomeration phenomena, solution variables, such as ionic strength and hydroxide concentration, can dramatically affect the apparent particle-size distributions in these types of materials when measured in this manner. Furthermore, the methods of transferring and mixing the sludge will likely have significant effects on the particle size distribution. Thus, the values presented here should be used with caution, especially if attempting to extrapolated to behavior to try to predict particle size distributions during actual processing. A summary of the median particle-size, mean particle-size, and the standard deviation of the mean particle-size (which provides a sense of the width of the distribution) is provided in Tables 3.2 and 3.3. In most cases, the initial sludges appeared similar in size and distribution, with mean number distribution on the order of $1 \mu \mathrm{m}$. Values for the volume distributions were higher and over a larger range, with measured mean values of 1 to $6 \mu \mathrm{m}$.

Several types of changes in the particle-size distributions as a function of sludge washing and caustic leaching were seen. In some cases, sludge washing and caustic leaching caused little change in the measured distributions of particle-size; C-103 and T-104 are examples of this first type of behavior. On the other hand, SY-103 showed a decrease in the measured particle-size as indicated both by volume and by number. A third type of behavior was shown by B-111, which showed a modest increase in the distribution by number, but a major increase in the particle-size by volume. Tanks BX-107, S-104, and T-111 sludges were similar to B-111. In these cases, the most modest increase in the particle-size by number translated into a major change in the particle-size distribution by volume. Overall, under the conditions of the particle size measurements, little change in the particle-size was measured as a result of 
Table 3.2. Number Distribution Summary for Particle-Size Analysis of Sludge Composites

\begin{tabular}{|c|c|c|c|}
\hline Sludge & Median $(\mu \mathrm{m})$ & Mean $(\mu \mathrm{m})$ & $\mathrm{SD}^{(\mathrm{a})}$ \\
\hline B-111 Untreated & 0.86 & 1.03 & 0.77 \\
\hline B-111 Treated & 0.92 & 1.43 & 2.48 \\
\hline BX-107 Untreated & 0.74 & 0.93 & 0.77 \\
\hline BX-107 Treated & 0.73 & 0.97 & 1.08 \\
\hline C-103 Untreated & 0.84 & 0.86 & 0.25 \\
\hline C-103 Treated & 0.88 & 0.90 & 0.27 \\
\hline S-104 Untreated & 0.81 & 0.95 & 0.53 \\
\hline S-104 Treated & 0.69 & 0.87 & 0.78 \\
\hline SY-103 Untreated & 0.87 & 1.07 & 0.83 \\
\hline SY-103 Treated & 0.76 & 0.82 & 0.27 \\
\hline T-104 Untreated & 0.71 & 0.90 & 0.80 \\
\hline T-104 Treated & 1.11 & 1.46 & 1.16 \\
\hline $\mathrm{T}-111$ Untreated & 1.03 & 1.52 & 1.30 \\
\hline T-111 Treated & 0.84 & 0.97 & 0.67 \\
\hline
\end{tabular}

(a) $\mathrm{SD}=$ Standard Deviation of the Mean

sludge washing and caustic leaching. An exception was SY-103, where some decrease in particle-size was found. 
Table 3.3. Volume Distribution Summary for Particle-Size Analysis of Sludge Composites

\begin{tabular}{|c|c|c|c|}
\hline Sludge & Median $(\mu \mathrm{m})$ & Mean $(\mu \mathrm{m})$ & $\mathrm{SD}^{(\mathrm{a})}$ \\
\hline B-111 Untreated & 3.70 & 3.66 & 1.82 \\
\hline B-111 Treated & 45.12 & 42.38 & 16.26 \\
\hline BX-107 Untreated & 4.71 & 5.67 & 3.77 \\
\hline BX-107 Treated & 22.22 & 20.70 & 11.60 \\
\hline C-103 Untreated & 1.07 & 1.06 & 0.25 \\
\hline C-103 Treated & 1.12 & 1.13 & 0.28 \\
\hline S-104 Untreated & 3.37 & 2.78 & 1.28 \\
\hline S-104 Treated & 26.98 & 23.18 & 15.80 \\
\hline SY-103 Untreated & 5.73 & 9.71 & 8.35 \\
\hline SY-103 Treated & 1.09 & 1.13 & 0.40 \\
\hline $\mathrm{T}-104$ Untreated & 4.48 & 4.85 & 2.64 \\
\hline T-104 Treated & 4.69 & 4.82 & 2.11 \\
\hline $\mathrm{T}-111$ Untreated & 4.44 & 4.82 & 2.22 \\
\hline T-111 Treated & 4.62 & 7.39 & 6.71 \\
\hline
\end{tabular}

(a) $\mathrm{SD}=$ Standard Deviation of the Mean

\subsection{Behavior of Nonradioactive Components During Sludge Washing and Caustic Leaching}

Tables are provided in the appendices listing the concentrations of the nonradioactive sludge components in the process solutions, the concentrations of the nonradioactive sludge components in the leached sludges, and the distribution of the nonradioactive sludge components into the various process streams. Mass-balance between the nonradioactive sludge components found in the process solutions plus the leached solids and those found by direct 
analysis of the untreated sludges are also given in the appendices. In general, the mass balance between the elemental composition of the untreated sludge and the elemental composition derived from the composition of the treated sludge together with the elemental composition of the wash solutions agreed well, typically within $20 \%$ and often within a few percent. Substantial deviations were found in selected cases: these usually involved elements present near their analytical detection limits, which added appreciably to the uncertainty of these values. Fortunately, such instances rarely include elements of most interest regarding the sludge washing and caustic leaching process (e.g., $\mathrm{Al}, \mathrm{Cr}, \mathrm{P}$ ). In the case of $\mathrm{BX}-107$, however, a general tendency existed towards lower elemental concentrations based on summation of the individual steps in the process as compared to the direct measurement of the elemental composition of the initial sludge. The reason for this is unknown, but incomplete drying of the final solid or the presence of a small amount of undissolved material in the analysis of the final solid are two possible explanations.

Table 3.4 summarizes how effectively several key nonradioactive elements were removed during sludge washing and caustic leaching for the seven sludges investigated. As expected for highly alkaline solutions, elements such as $\mathrm{Bi}$ and $\mathrm{Fe}$ did not generally dissolve. A significant fraction of the Fe was removed from SY-103 sludge. As noted previously, this complexant concentrate waste would be expected to contain chemical agents capable of solubilizing metal cations even in alkaline solutions, consistent with the observed result. Other key elements, such as $\mathrm{Al}, \mathrm{P}$, and $\mathrm{Si}$, showed highly variable dissolution behavior in response to sludge washing and caustic leaching. The extent to which this variable behavior is consistent with the planning assumptions made in the baseline pretreatment flowsheet will be discussed in Section 3.7.

\subsection{Behavior of Anionic Components During Sludge Washing and Caustic Leaching}

Tables are provided in the appendices listing the concentrations of key anions in the process solutions, the concentrations of key anions in the leached sludges, and the distribution of key anions into the various process streams. Results of a mass balance calculation for key 
Table 3.4. Summary of the Effectiveness of Sludge Washing and Caustic Leaching in Removing Key Nonradioactive Components

\begin{tabular}{|c|c|c|c|c|c|c|c|}
\hline \multirow[b]{2}{*}{ Tank } & \multicolumn{7}{|c|}{ Amount of Component Removed, \% } \\
\hline & $\mathrm{Al}$ & $\mathrm{Bi}$ & $\mathrm{Ca}$ & $\mathrm{Cr}$ & $\mathrm{Fe}$ & $\mathbf{P}$ & $\mathrm{Si}$ \\
\hline B-111. & 2 & 0 & 12 & 40 & 0 & 91 & 47 \\
\hline BX-107 & 68 & 0 & 27 & 29 & 0 & 93 & 2 \\
\hline C-103 & 48 & (a) & 1 & 11 & 0 & 66 & 1 \\
\hline S-104 & 38 & 0 & 36 & 97 & 1 & (b) & 0 \\
\hline SY-103 & 90 & 0 & 76 & 12 & 25 & 98 & 80 \\
\hline $\mathrm{T}-104$ & 62 & 0 & 27 & 27 & 0 & 55 & 1 \\
\hline $\mathrm{T}-111$ & 13 & 0 & 1 & 63 & 0 & 72 & 59 \\
\hline
\end{tabular}

(a) Bismuth was present at less than its detection limits for both the initial and leached sludges and at close to its detection limits in the leach solutions.

(b) Phosphonus was not detected in this sample.

anions and its comparison to the directly measured concentrations in the untreated sludges are also provided in the appendices. The anions measured were $\mathrm{NO}_{2}{ }^{-}, \mathrm{NO}_{3}{ }^{-}, \mathrm{PO}_{4}{ }^{3-}, \mathrm{SO}_{4}{ }^{2-}, \mathrm{F}^{-}, \mathrm{Cl}^{-}$, and $\mathrm{Br}^{-}$. Table 3.5 summarizes these results for two anions of special importance, phosphate and sulfate. Quantification and mass-balance calculation for the other anions proved to be impractical for differing reasons. Nitrate, nitrite, and occasionally chloride could not be measured in the solids due to the overwhelming contributions of the $\mathrm{HNO}_{3}$ and $\mathrm{HCl}$ required to dissolve the solids. Consequently, mass balance calculations could not be performed, and the percent removed in each process step could not be determined. Indeed, the analysis of all anions is affected by the dilutions required to keep the total anion concentrations low enough to avoid overwhelming the column's capacity. Fluoride in principle ought to have been detectable in the solids by IC, but is masked by the presence of elements such as Al. The IC results measure only free fluoride concentration, but $\mathrm{Al}, \mathrm{Zr}$, and some other metallic elements complex fluoride so strongly that fluoride will not be found by IC in their presence. However, 
Table 3.5. Summary of Phosphate and Sulfate Removal by Sludge Washing and Caustic Leaching

\begin{tabular}{|c|c|c|c|}
\hline \multirow[b]{2}{*}{ Tank } & \multicolumn{3}{|c|}{ Amount of Component Removed, \% } \\
\hline & Phosphate $^{(a)}$ & Phosphorus $^{(\mathbf{b})}$ & Sulfate ${ }^{(\mathbf{a})}$ \\
\hline B-111 & 96 & 91 & 100 \\
\hline BX-107 & 97 & 93 & 95 \\
\hline C-103 & (c) & 66 & (c) \\
\hline S-104 & (d) & (d) & 100 \\
\hline$S Y-103$ & (c) & 98 & (c) \\
\hline $\mathrm{T}-104$ & 89 & 55 & 100 \\
\hline $\mathrm{T}-111$ & 76 & 72 & 67 \\
\hline $\begin{array}{ll}\text { (a) } \mathrm{De} \\
\text { (b) } \mathrm{De} \\
\text { (c) } \mathrm{Dr} \\
& \mathrm{no} \\
\text { (d) } & \mathrm{Th}\end{array}$ & $\begin{array}{l}\text { ad by IC analysis } \\
\text { d by ICP/AES } \\
\text { atrix effects, acc } \\
\text { formed. } \\
\text { es was not detec }\end{array}$ & $\begin{array}{l}\text { termination of thes } \\
\text { is sludge. }\end{array}$ & tes could \\
\hline
\end{tabular}

its presence in the sludges is indicated by its detection in the retrieval wash solutions. The metallic elements that mask fluoride generally are not soluble under such conditions. Finally, the amount of bromide in these samples appears to be so small that it was simply not detected.

Overall, the phosphate removal as measured by IC analysis agreed remarkably well with that indicated by ICP/AES analysis, especially considering the high detection limits of the IC method. The only significant deviation in the results obtained by these two methods was found in T-104; the reasons for this discrepancy are unknown. No such check is available on the sulfate analyses, but the close agreement in the $P$ values lends confidence as to the validity of the sulfate values.

In general, the anion concentrations determined by direct IC analysis agreed (within $20 \%$ ) with those determined by summing the components found in the treated sludge and in the wash and leach solutions. The major exceptions were the T-104 phosphate (55\% recovery) 
and sulfate ( $41 \%$ recovery) analyses and the sulfate analyses for S-104 (9\% recovery). The sulfate recovery for S-104 assumed no sulfate in the treated sludge because this component was below the detection limit. If the sulfate were present in the treated sludge at close to the detection limits, better agreement would be obtained. Even so, the high detection limit for sulfate in the treated sludge provided only a partial explanation: if the detection limit was used for the sulfate concentration in the treated sludge, the mass balance agreement increased only to $26 \%$. The source for the discrepancy remains unknown.

Table 3.6 compares the concentrations obtained by IC for phosphate with those obtained for $\mathrm{P}$ by ICP/AES for the treated and untreated sludges. With the exception, as noted above, of the treated sludge of T-104, reasonable agreement between the two methods is seen. Such a result corroborates the assumption that the $\mathrm{P}$ measured in the ICP/AES is actually present in the sludges as phosphate.

\subsection{Radionuclide Behavior During Sludge Washing and Caustic Leaching}

Table 3.7 summarizes the behavior of the radiochemical components during the sludge washing and caustic leaching tests. Ideally, no radionuclides would be removed from the sludge because the sludge solids are to be routed to HLW disposal. Analysis of the total alpha content as well as the gamma-energy analysis confirm that the transuranic elements were not removed to any significant extent during sludge washing and caustic leaching. Analogous

results were seen for ${ }^{90} \mathrm{Sr}$. Tank SY-103 is a modest exception: it showed a small amount of TRU removal (1\%) as well as a small amount of ${ }^{90} \mathrm{Sr}$ removal (4\%), consistent with the presence of metal-solubilizing complexing agents in this complexant concentrate (CC) waste. As expected, ${ }^{137} \mathrm{Cs}$ and ${ }^{99} \mathrm{Tc}$ generally were readily removed by sludge washing and caustic leaching; perhaps the most interesting result is how much the removal of these radioelements varied. For example, ${ }^{137} \mathrm{Cs}$ removal ranged from quantitative for SY-103 to only $13 \%$ for T-104. Technetium-99 removal also varied from quantitative for S-104 and B-111 to $12 \%$ removal with $\mathrm{T}-111$. 
Table 3.6. Summary of Phosphate and Phosphorus Concentrations in Treated vs. Untreated Sludges

\begin{tabular}{|c|c|c|c|c|}
\hline \multirow[b]{3}{*}{ Tank } & \multicolumn{4}{|c|}{ Equivalents P/g Dry Sludge } \\
\hline & \multicolumn{2}{|c|}{ Untreated Sludge } & \multicolumn{2}{|c|}{ Leached Sludge } \\
\hline & By IC & $\begin{array}{c}\text { By } \\
\text { ICP/AES }\end{array}$ & By IC & $\begin{array}{c}\text { By } \\
\text { ICP/AES }\end{array}$ \\
\hline B-111 & $1.3 \mathrm{E}-03$ & $1.3 \mathrm{E}-03$ & $2.1 \mathrm{E}-04$ & $5.2 \mathrm{E}-04$ \\
\hline BX-107 & $1.4 \mathrm{E}-03$ & $1.8 \mathrm{E}-03$ & $2.1 \mathrm{E}-04$ & $5.5 \mathrm{E}-04$ \\
\hline C-103 & (a) & $1.6 \mathrm{E}-04$ & (a) & $9.7 \mathrm{E}-05$ \\
\hline S-104 & (b) & (b) & (b) & (b) \\
\hline$S Y-103$ & (a) & $2.5 \mathrm{E}-04$ & (a) & $2.3 \mathrm{E}-05$ \\
\hline $\mathrm{T}-104$ & $2.5 \mathrm{E}-03$ & $2.2 \mathrm{E}-03$ & $3.2 \mathrm{E}-04$ & $2.0 \mathrm{E}-03$ \\
\hline $\mathrm{T}-111$ & $5.3 \mathrm{E}-04$ & $8.4 \mathrm{E}-04$ & $3.2 \mathrm{E}-04$ & $4.6 \mathrm{E}-04$ \\
\hline
\end{tabular}

(a) Due to matrix effects, accurate determination of these analytes could not be performed.

(b) Phosphorus and phosphate were not detected in this sample.

The radionuclide content of the wash and leach solutions is of interest regarding LLW disposal. Because the LLW form has not yet been defined, a rigorous assessment cannot be performed. However, for the purposes of this discussion, it is assumed that the LLW form will contain $\sim 23 \mathrm{wt} \% \mathrm{Na}_{2} \mathrm{O}$ and have a density of $2.65 \mathrm{~g} / \mathrm{mL}$; i.e., the $\mathrm{Na}$ concentration will be $20 \mathrm{M}$. For most of the tanks examined in this work, if the wash and leach solutions were combined and concentrated to $20 \mathrm{M} \mathrm{Na}$, the resulting mixtures could likely be classified as Nuclear Regulatory Commission (NRC) Class C LLW (10 CFR 61). An exception to this is seen for C-103 sludge, which would have a TRU concentration in the LLW stream close the the $0.1 \mu \mathrm{Ci} / \mathrm{g}$ Class $\mathrm{C}$ limit. 
Table 3.7. Summary of Radionuclide Removal by Sludge Washing and Caustic Leaching

\begin{tabular}{|c|c|c|c|c|}
\hline \multirow[b]{2}{*}{ Tank } & \multicolumn{4}{|c|}{ Amount of Component Removed, \% } \\
\hline & Total Alpha ${ }^{(a)}$ & ${ }^{90} \mathrm{Sr}$ & ${ }^{137} \mathrm{Cs}$ & ${ }^{99} \mathrm{Tc}$ \\
\hline B-111 & $<0.1$ & $<0.02$ & 95 & 100 \\
\hline BX-107 & $<0.2$ & $<0.2$ & 94 & 99 \\
\hline C-103 & $<0.4$ & $<0.2$ & 73 & 68 \\
\hline S-104 & $<0.1$ & $<0.08$ & 98 & 100 \\
\hline SY-103 & $<0.9$ & $<4$ & 100 & 85 \\
\hline $\mathrm{T}-104$ & $<0.1$ & $<2$ & 13 & (b) \\
\hline $\mathrm{T}-111$ & $<0.1$ & $<0.05$ & 56 & 12 \\
\hline
\end{tabular}

(a) The total alpha behavior reflects the behavior of the TRU elements.

(b) Radionuclide not detected in this sludge.

\subsection{Comparison of the Sludge Washing and Caustic Leaching Results to the Tank Waste Remediation System Planning Assumptions}

In this section, the results of the sludge washing and caustic leaching tests are compared to the planning assumptions used to design the baseline sludge-treatment flowsheet (Orme 1994).

One of the planning assumptions in the current baseline flowsheet concerns the amount of $\mathrm{Al}$ removed by sludge washing and caustic leaching. The existing assumption is that $\mathrm{Al}$ and $\mathrm{Si}$ form an unleachable material (e.g., cancrinite) having a 1:1 molar composition. If there is a molar excess of $\mathrm{Al}$ over $\mathrm{Si}$, then $85 \%$ of the excess $\mathrm{Al}$ will be removed by sludge washing and caustic leaching. Figure 3.5 compares the results of sludge wash and caustic leach testing of Hanford tank sludges to those expected based on this assumption using data not only from the work described in this report but also the results of previous studies (Lumetta and Rapko 1994) 
and work conducted in FY 1995 at Los Alamos National Laboratory (LANL) (Temer and Villareal 1995).

In almost every instance, the measured removal of $\mathrm{Al}$ was more effective than that expected from the planning assumption. A striking exception was S-104, where only about one-half of the expected amount of $\mathrm{Al}$ was dissolved. Transmission electron microscopy (TEM) and scanning electron microscopy (SEM) characterization of S-104 sludge indicated that the aluminum oxides in this tank exist primarily as boehmite, unlike the other sludges, where the aluminum oxides generally exist as gibbsite. ${ }^{(a)}$ Boehmite is much more difficult to dissolve in alkaline solutions than gibbsite, which could explain the observed results (Weber 1982). Alternatively, it is possible that the low Al removal for S-104 sludge was due to saturation of the leach solutions with $\mathrm{Al}$; that is, the $\mathrm{Al}$ removal might have been constrained by solubility rather than by kinetics. This explanation seems unlikely because significantly higher Al concentrations were achieved in leaching with other sludges (C-103 and SY-103) under similar conditions. A third possible explanation lies in the fact that the leach solutions were sampled at room temperature whereas the actual leaching step was performed at $100^{\circ} \mathrm{C}$. It is possible that a fraction of the Al precipitated when the solution cooled, but before the solution was sampled. Three points can be put forth to refute the latter explanation. First, as mentioned above, leach solutions from other tests contained significantly higher $\mathrm{Al}$ concentrations than the S-104 sludge leach solutions. There is no reason to believe that $\mathrm{Al}$ would precipitate from the S-104 solution on cooling, but not from the others. Second, the Al mass balance between the amount of $\mathrm{Al}$ revealed by direct analysis of the sludge versus that obtained by summing the amount of $\mathrm{Al}$ found in the wash and leach solutions and that found in the leached sludge (Table D.4) was within $20 \%$. Indeed the percent recovery of Al was greater than 100; if Al precipitated upon cooling, the Al mass recovery would be significantly below 100. Third, microscopy studies of the leached sludge indicated boehmite as the exclusive Al-containing species. If a fraction of the Al precipicated on cooling of the

(a) J. P. Lafemina and others (1995). Report entitled Tank Waste Treatment Science: Report for the Second Quarter FY 1995. TWRSPP-95-008. Pacific Northwest Laboratory, Richland, Washington. 


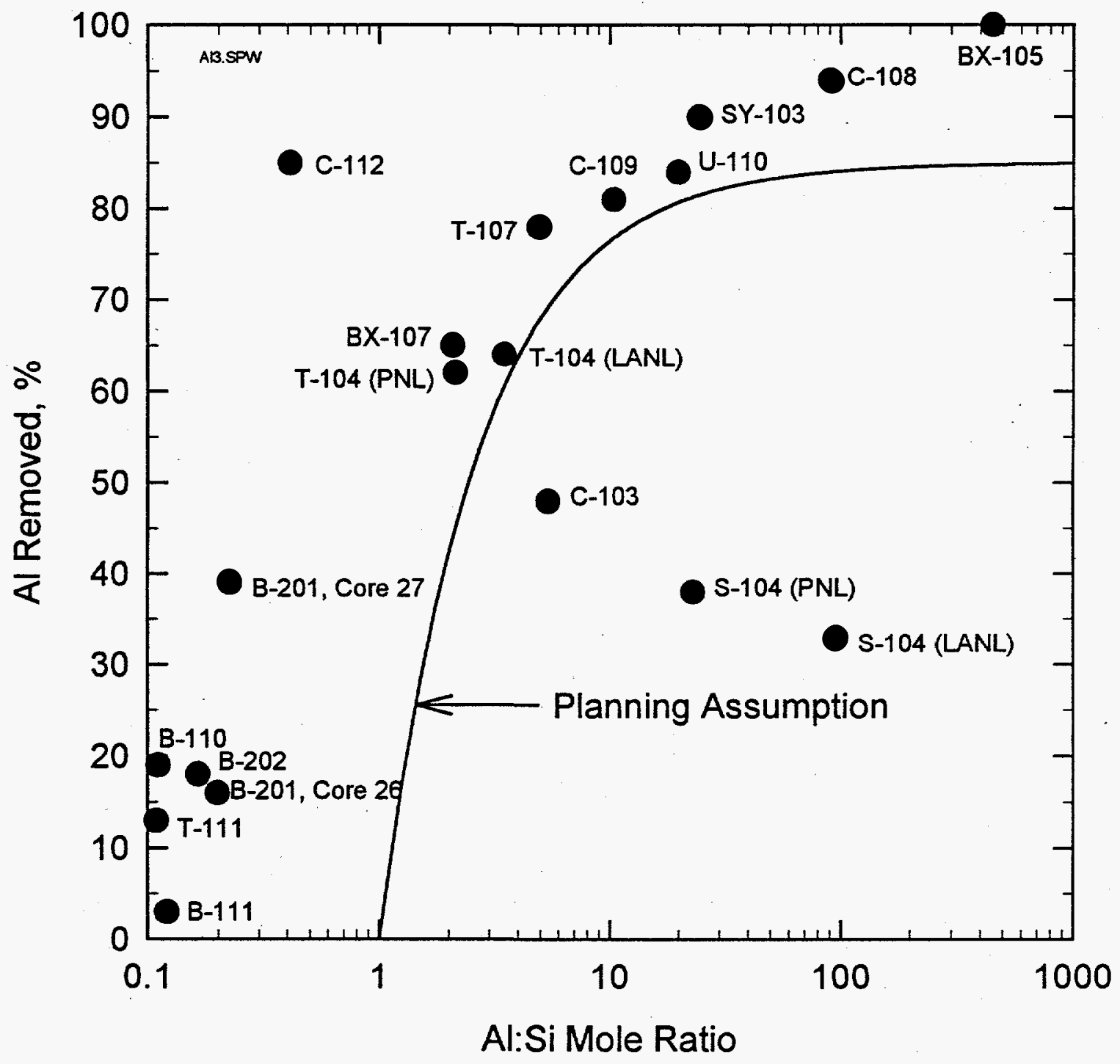

Figure 3.5 Observed Aluminum Dissolution vs. Baseline Assumption 
leach mixture, that fraction of $\mathrm{Al}$ would not be present as boehmite because boehmite is formed under more harsh conditions. Thus, the most likely explanation for the low removal of Al from S-104 sludge is that the dissolution of boehmite is kinetically slow.

Another sludge that displayed low $\mathrm{Al}$ removal compared to the baseline assumption was C-103 sludge; however, in that case, the leach was performed at a free hydroxide concentration (1 M), well below the targeted value of $3 \mathrm{M}$ (see Table 2.1). Presumably, at a higher hydroxide concentration, additional Al would be removed from the $\mathrm{C}-103$ sludge. Also, the possibility that low $\mathrm{Al}$ removal was due to saturation limits cannot be ruled out for the $\mathrm{C}-103$ test. The $\mathrm{Al}$ concentration in the second leach solution was greater than that in the first (refer to Table C.1), indicating that the solutions might have been Al-saturated.

The $85 \%$ removal of $\mathrm{Al}$ in molar excess of $\mathrm{Si}$ assumed in the baseline flowsheet is based on an idealized blend of the tank sludge wastes. Based on the current sludge inventories, ${ }^{\left({ }^{(a)}\right.}$ if sludge from the twelve tanks investigated by PNL to date were blended, the resulting material would contain $1.50 \times 10^{7}$ moles of $\mathrm{Al}$ in excess of the number of moles of Si present. Using the $\mathrm{Al}$ removal factors from tank-to-tank, a total of $1.19 \times 10^{7}$ moles of $\mathrm{Al}$ would be removed by washing and leaching, which translates to $80 \%$ of the Al present in excess of $\mathrm{Si}$. This value is $5 \%$ less than the assumed $85 \%$ removal, with the low S-104 Al removal having a large effect on the overall $\mathrm{Al}$ removal from this set of tanks. When all the $\mathrm{Al}$ is considered in these twelve tanks ( $1.84 \times 10^{7}$ moles), the cumulative $\mathrm{Al}$ removal would be $65 \%$.

One caveat concerns the interpretation of Figure 3.5-the Al to Si molar ratio used in Figure 3.5 uses the initial $\mathrm{Al}: \mathrm{Si}$ molar ratio, and no Si dissolution is assumed. Table 3.8 shows the mole ratio of $\mathrm{Al}: \mathrm{Si}$ for the final washed and leached solids. If all of the $\mathrm{Al}$ and $\mathrm{Si}$ leaching behavior could be explained by formation of a 1:1 Al:Si species together with $85 \%$ dissolution of the excess $\mathrm{Al}$, then the final $\mathrm{Al} / \mathrm{Si}$ ratio in the treated solids should be around 1.2. A smaller value corresponds to more effective $\mathrm{Al}$ dissolution than anticipated in the baseline assumption while a higher value indicates less effective $\mathrm{Al}$ dissolution. Table 3.8 estimated by assuming a sludge density of $1.5 \mathrm{~g} / \mathrm{mL}$. 
Table 3.8. Aluminum and Silicon Molar Concentrations in Treated Sludges

\section{Concentration in Leached}

Sludge, mole/g

\begin{tabular}{|c|c|c|c|}
\hline Tank & $\mathrm{Al}$ & $\mathrm{Si}$ & $\mathrm{Al} / \mathrm{Si}$ in Leached Sludge \\
\hline B-111 & $6.7 \mathrm{E}-04$ & $2.3 \mathrm{E}-03$ & 0.29 \\
\hline BX-107 & $1.5 \mathrm{E}-03$ & $1.7 \mathrm{E}-03$ & 0.87 \\
\hline C-103 & $3.9 \mathrm{E}-03$ & $1.2 \mathrm{E}-03$ & 3.2 \\
\hline S-104 & $1.2 \mathrm{E}-02$ & $1.8 \mathrm{E}-04$ & 67 \\
\hline SY-103 & $3.1 \mathrm{E}-03$ & $4.3 \mathrm{E}-04$ & 7.2 \\
\hline $\mathrm{T}-104$ & $1.2 \mathrm{E}-03$ & $1.3 \mathrm{E}-03$ & 0.9 \\
\hline T-111 & $2.1 \mathrm{E}-04$ & $1.2 \mathrm{E}-03$ & 0.18 \\
\hline
\end{tabular}

shows that the dissolution behavior of $\mathrm{Al}$ and $\mathrm{Si}$ is poorly described by this simple model, with values both appreciably higher and lower than expected. Thus, it appears that the simple model used to estimate $\mathrm{Al}$ behavior in the planning assumption has little validity regarding the chemistry of the systems.

The planning assumption in the current baseline flowsheet regarding $\mathrm{P}$ removal can be stated as " $70 \%$ of the water insoluble fraction of the $\mathrm{P}$ is removed by caustic leaching." Although this $70 \%$ removal factor is applied to an overall blend of the tank sludges in the flowsheet, it is illustrative to compare this assumption to the results for each tank studied to date. The percentage of the water insoluble $P$ in each sludge removed by caustic leaching is presented in Table 3.9. As might be expected, the actual efficacy of caustic leaching in removing $P$ varies greatly from tank to tank. However, when the entire $P$ inventory (see footnote on page 3.20) is considered for the tanks investigated to date, the overall removal of the water insoluble fraction of the $\mathrm{P}$ is $65 \%$, which is near the assumed value of $70 \%$. 
Table 3.9. Water Insoluble Phosphorus Removed by Caustic Leaching

\begin{tabular}{|c|c|}
\hline Tank & Water Insoluble P Removed by Caustic Leaching, \% \\
\hline B-110 & 81 \\
\hline B-111 (b) & 84 \\
\hline $\mathrm{B}-201^{(\mathbf{a}, \mathrm{c})}$ & 25 \\
\hline $\mathrm{BX}-107^{(\mathrm{b})}$ & 91 \\
\hline$C-103^{(b)}$ & 54 \\
\hline$C-109^{(a)}$ & 13 \\
\hline$C-112^{(a)}$ & 69 \\
\hline$S Y-103^{(b)}$ & 92 \\
\hline$T-104^{(b)}$ & 39 \\
\hline $\mathrm{T}-111^{(\mathrm{b})}$ & 45 \\
\hline $\mathrm{U}-110^{(\mathrm{c})}$ & 90 \\
\hline $\begin{array}{l}\text { (a) Data t } \\
\text { (b) Data } \\
\text { (c) Avera }\end{array}$ & $\begin{array}{l}\text { Rapko (1994). } \\
\text { cores } 26 \text { and } 27 \text { used. }\end{array}$ \\
\hline
\end{tabular}

An alternative assumption for $\mathrm{P}$ removal by sludge washing and caustic leaching supposes that all of the $\mathrm{P}$ (presumed to be present as phosphate) will be removed except that portion that forms an insoluble and unleachable phase with alkaline earth metals. Unlike most water-insoluble phosphates, those of the alkaline earth elements are not expected (based on thermodynamics) to be metathesized to hydroxides (thus releasing the phosphate so that it can be washed away) in the caustic leach step.

The stoichiometry of simple alkaline earch phosphates requires a 3:2 molar ratio of alkaline-earth metal to P. In Hanford tank sludges, the amount of alkaline earth metal present is generally dominated by the amount of $\mathrm{Ca}$ and, in some cases, by the amount of $\mathrm{Ca}$ and $\mathrm{Sr}$ present. Figure 3.6 compares the results of sludge wash and caustic leach testing of Hanford tank sludges to that expected based on the unleachable alkaline earth phosphate hypothesis, 


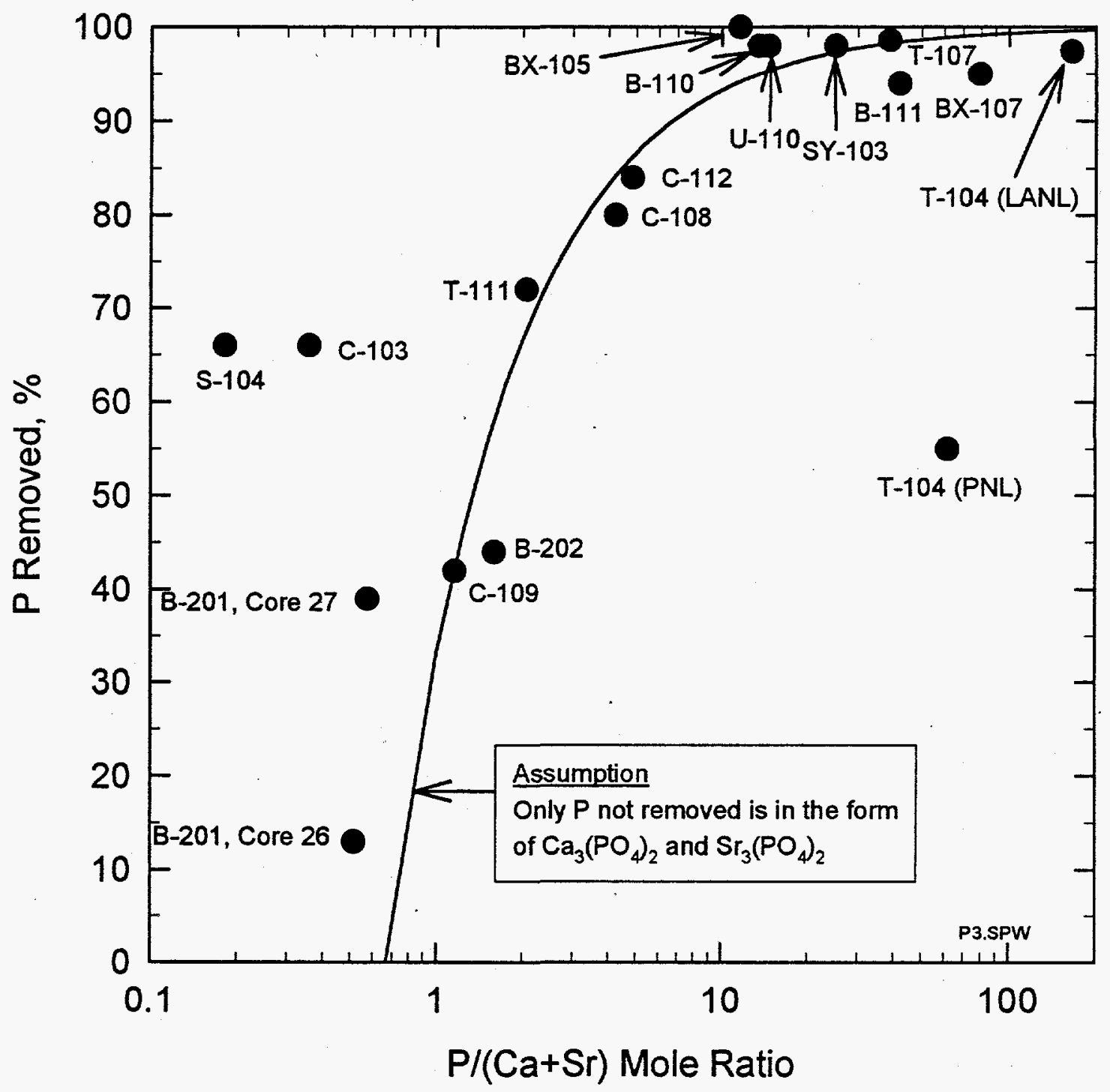

Figure 3.6. Observed Phosphorus Removal Compared to the Unleachable Alkaline-Earth Phosphate Hypothesis. The solid line represents the removal of $P$ expected if only $\mathrm{Ca}$ and $\mathrm{Sr}$ phosphates were not leached from the sludge. using data from the tests conducted to date. 
For the most part, the data fall near the curve associated with the hypothesis. Results from the B-111, B-202, BX-107, C-108, and C-112 tests show slightly poorer than expected removal of $\mathrm{P}$ based upon this hypothesis. The major discrepancy is found for the T-104 sludge.

Two additional concerns are associated with the test results from T-104. First, as revealed in Tables 3.5 and 3.6, comparing the amount of $\mathrm{P}$ removed (based on ICP/AES data for $\mathrm{P}$ ) with the amount of phosphate removed (based on IC data) produced results that are very different for $\mathrm{T}-104$. Only $\mathrm{T}-104$ produced such differences, however, raising a cautionary note about these values. Figure 3.6 was generated using ICP/AES data in all instances. The $P$ removal (89\%) indicated by the IC data for T-104 was much closer the value expected by the unleachable alkaline-earth phosphate hypothesis. In addition, recent work at Los Alamos National Laboratory (Temer and Villarreal 1995), where the same test was performed on T-104, gave very different results. The LANL results are much more in line with the unleachable alkaline-earth phosphate hypothesis, although they too indicate slightly less effective P removal than expected from the hypothesis. The combination of the LANL T-104 results together with the phosphate/P discrepancy suggests that the $\mathrm{T}-104$ values should be viewed with some caution. Be that as it may, quantitative material balance for $\mathrm{P}$ was achieved by the ICP/AES analysis whereas only a $55 \%$ recovery for $\mathrm{PO}_{4}{ }^{3-}$ was achieved by IC analysis (see Table F.4). Thus, in the case of the work performed at PNL, the value of $55 \%$ removal of $\mathrm{P}$ from T-104 sludge seems to be the most reliable.

In an attempt to validate the hypothesis that only the alkaline-earth phosphates are not removed by washing and caustic leaching, the $\mathrm{P} /(\mathrm{Ca}+\mathrm{Sr})$ mole ratio in the treated solids was considered (Table 3.10). If the only P-containing species in the leached residue are $\mathrm{Ca}$ and $\mathrm{Sr}$ phosphates, the $\mathrm{P} /(\mathrm{Ca}+\mathrm{Sr})$ molar ratio in the residue should be 0.67 . A lower value would indicate that the assumption is a conservative one, either because of insufficient $\mathrm{P}$ being initially present relative to $\mathrm{Ca}$, or due to some additional $\mathrm{P}$-removing processes occurring.

The results are clearly mixed regarding the insoluble alkaline-earth metal phosphate hypothesis. In two cases, with $\mathrm{S}-104$ and $\mathrm{SY}-103$, the $\mathrm{P}(\mathrm{Ca}+\mathrm{Sr})$ ratio is clearly lower than expected if all of the $\mathrm{Ca}$ and $\mathrm{Sr}$ complexed with the $\mathrm{P}$ to form the corresponding phosphates. 
Table 3.10. Phosphorus, Calcium, and Strontium Concentrations in Treated Sludges

\begin{tabular}{|c|c|c|c|c|}
\hline \multirow[b]{2}{*}{ Tank } & \multicolumn{3}{|c|}{ Concentration in Leached Sludge, mole/g } & \multirow[b]{2}{*}{$\mathrm{P} /(\mathrm{Ca}+\mathrm{Sr})$ in Leached Sludge } \\
\hline & $\mathbf{P}$ & $\mathrm{Ca}$ & $\mathrm{Sr}$ & \\
\hline B-111 & $5.2 \mathrm{E}-04$ & $1.8 \mathrm{E}-04$ & $2.4 \mathrm{E}-05$ & 2.7 \\
\hline BX-107 & $5.5 \mathrm{E}-04$ & 3.7E-05 & $1.1 \mathrm{E}-05$ & 11 \\
\hline C-103 & 9.7E-05 & $2.2 \mathrm{E}-04$ & 2.3E-06 & 0.44 \\
\hline S-104 & 0 & 4.5E-05 & $2.5 \mathrm{E}-05$ & 0 \\
\hline SY-103 & $2.3 \mathrm{E}-05$ & $1.3 \mathrm{E}-04$ & $1.1 \mathrm{E}-06$ & 0.18 \\
\hline $\mathrm{T}-104$ & 2.0E-03 & 4.5E-05 & $7.6 \mathrm{E}-06$ & 38 \\
\hline $\mathrm{T}-111$ & 4.2E-04 & 5.5E-04 & $1.5 \mathrm{E}-05$ & 0.74 \\
\hline
\end{tabular}

In the case of $\mathrm{S}-104$, this is because the solids contained little or no $\mathrm{P}$ to begin with. The $\mathrm{P}(\mathrm{Ca}+\mathrm{Sr})$ ratio of 0.77 observed for the treated $\mathrm{T}-111$ solid is very close to the 0.67 ratio expected. However, with B-111, BX-107, C-103, and T-104, the P:Ca ratio is just as clearly higher than expected, indicating that other P-containing species are present in the treated solids. Thus, the good correlation indicated in Figure 3.6 is likely based on coincidence rather than on chemical fact. Nevertheless, this hypothesis has thus far proved to be a remarkably good assumption, given the complexity of the systems examined.

One aspect of the current sludge pretreatment testing strategy is to divide the tanks into groups having similar waste types based on the sort on radioactive waste type (SORWT) model (Hill, Anderson, and Simpson 1995). It is commonly presumed that wastes from tanks within a given SORWT group will exhibit similar behavior in the sludge washing and caustic leaching pretreatment process. If this were the case, then it would not be necessary to perform tests on every tank within the SORWT group, but rather sludges from selected tanks could be tested and the results extrapolated to the other tanks in the same SORWT groups. 
Several examples exist in which tanks in the same SORWT group have been tested. Table 3.11 summarizes these along with the observed removals of $\mathrm{Al}, \mathrm{Cr}$, and $\mathrm{P}$. The general trends between SORWT groups is consistent. For example, removing Al from tanks in SORWT groups X and XIII is generally better than from tanks in groups VII and XVI. However, significant variability is seen for removing certain components within given SORWT groups. This is especially true for P removal from groups VII and XIII tanks, Al removal from group XVI tanks, and Cr removal from group VII tanks. Clearly, much more data are needed to validate the use of SORWT (or other models) for extrapolating test results to tanks that have not actually been tested.

\subsection{Impact on High-Level Waste Glass Volume}

This discussion concludes with the reduction in HLW glass volume achieved by sludge washing and caustic leaching. Table 3.12 illustrates the calculated amount of glass canisters (each canister containing $1650 \mathrm{~kg}$ of borosilicate glass) expected from vitrifying the sludge solids in the seven tanks investigated in this work. Three cases are considered: no pretreatment, washing with inhibited water, and caustic leaching plus washing with inhibited water. The vitrification feed specifications reported by Swanson (1993) were used to calculate the number of glass canisters resulting in each case. To determine the number of glass canisters, the total mass of each potential glass-limiting component in the untreated sludge was determined by multiplying the total amount of sludge (on a dry weight basis) by the concentration of each component in the untreated sludge as reported in the appendices. The total amount of sludge in each tank was taken from Colton (1995), except for SY-103, which was obtained from Hanlon (1995). For the "no pretreatment" case, these component masses

were used directly. For the other two cases, the amount of each component in the HLW was obtained by multiplying the amount of that component originally in the waste by the fraction left after the inividual treatment. The total mass of each element in the HLW stream was then compared to its allowable limits in the HLW vitrification feed (Swanson 1993) to determine the number of HLW glass canisters that would result from each component. The three 
Table 3.11.

Comparison of Sludge Washing and Caustic Leaching Results from Tanks In the Same SORWT Groups

\begin{tabular}{|c|c|c|c|c|}
\hline & & & e $\mathbf{R}$ & \\
\hline & $\begin{array}{c}\text { SORWT } \\
\text { Group }\end{array}$ & Al & $\mathrm{Cr}$ & $\mathbf{P}$ \\
\hline B-110 (a) & XVI & 18 & 52 & 98 \\
\hline B-111 & XVI & 2 & 40 & 91 \\
\hline Mean & & 10 & 46 & 94 \\
\hline Std. Dev. & & 11 & 8 & 5 \\
\hline B-201 $1^{(a, b)}$ & VII & 27 & 56 & 26 \\
\hline B-202 ${ }^{(\mathrm{c})}$ & VII & 19 & 29 & 44 \\
\hline Mean & & 23 & 42 & 35 \\
\hline Std. Dev. & & 6 & 19 & 13 \\
\hline $\mathrm{C}-108^{(\mathrm{c})}$ & XIII & 94 & 80 & 80 \\
\hline$C-109^{(a)}$ & XIII & 81 & 85 & 42 \\
\hline$C-112^{(a)}$ & XIII & 85 & 88 & 84 \\
\hline Mean & & 87 & 84 & 69 \\
\hline Std. Dev. & & 7 & 4 & 23 \\
\hline $\mathrm{T}-107^{(\mathrm{c})}$ & $\mathrm{X}$ & 78 & 61 & 99 \\
\hline $\mathrm{U}-110^{(a)}$ & $\mathrm{X}$ & 84 & 71 & 98 \\
\hline Mean & & 81 & 66 & 98 \\
\hline Std. Dev. & & 4 & 7 & 1 \\
\hline
\end{tabular}

(a) Lumetta and Rapko 1994.

(b) Average of the results from two cores.

(c) Temer and Villarreal 1995. 
Table 3.12. Impact of Sludge Washing and Caustic Leaching on Glass Required for Sludge Vitrification

\begin{tabular}{|c|c|c|c|c|c|c|}
\hline \multirow{2}{*}{$\frac{\text { Tank }^{(a)}}{\text { B-111 (untreated) }}$} & \multicolumn{2}{|c|}{$\begin{array}{l}\text { Largest Number of } \\
\text { Glass Canisters } \\
\text { (Limiting Component) }\end{array}$} & \multicolumn{2}{|c|}{$\begin{array}{l}\text { 2nd Largest Number of } \\
\text { Glass Canisters } \\
\text { (Limiting Component) }\end{array}$} & \multicolumn{2}{|c|}{$\begin{array}{l}\text { 3rd Largest Number of } \\
\text { Glass Canisters } \\
\text { (Limiting Component) }\end{array}$} \\
\hline & 2290 & (P) & 1600 & (S) & 1550 & $(\mathrm{Na})$ \\
\hline B-111 (SW) & 1300 & (P) & 160 & $\left(C_{r}\right)$ & 130 & (S) \\
\hline $\mathrm{B}-111(\mathrm{SW}+\mathrm{CL})$ & 210 & (P) & 170 & (Na) & 130 & $(\mathrm{Cr})$ \\
\hline BX-107 (untreated) & 5210 & (P) & 2260 & $(\mathrm{Na})$ & 1430 & (S) \\
\hline BX-107 (SW) & 4170 & (P) & 630 & $(\mathrm{~F})$ & 220 & $(\mathrm{Cr})$ \\
\hline BX-107 (SW+CL) & 370 & (P) & 350 & (Na) & 200 & (Cr) \\
\hline C-103 (untreated) & 300 & (Al) & 120 & (Fe) & 90 & $(\mathrm{Na})$ \\
\hline C-103 (SW) & 300 & (Al) & 120 & $(\mathrm{Fe})$ & 600 & (P) \\
\hline $\mathrm{C}-103(\mathrm{SW}+\mathrm{CL})$ & 160 & (A) & 120 & $(\mathrm{Fe})$ & 80 & $(\mathrm{Na})$ \\
\hline S-104 (untreated) & 3460 & $(\mathrm{Na})$ & 2900 & (Al) & 2300 & (S) \\
\hline S-104 (SW) & 2810 & (A) & 170 & $(\mathrm{Na})$ & 100 & $(U)$ \\
\hline S-104 (SW+CL) & 1800 & (A) & 250 & $(\mathrm{Na})$ & 100 & $(\mathrm{U})$ \\
\hline SY-103 (untreated) & 14500 & $(\mathrm{Na})$ & 7540 & (Cr) & 3500 & (P) \\
\hline SY-103 (SW) & 7160 & (Cr) & 2480 & (Al) & 910 & (P) \\
\hline SY-103 (SW+CL) & 6630 & (Cr) & 270 & (Al) & 90 & $(\mathrm{Na})$ \\
\hline T-104 (untreated) & 5370 & (P) & 1710 & $(\mathrm{Na})$ & 1710 & (S) \\
\hline T-104 (SW) & 3970 & (P) & 470 & (Al) & 260 & (Cr) \\
\hline $\mathrm{T}-104(\mathrm{SW}+\mathrm{CL})^{(\mathrm{b})}$ & 2420 & (P) & 980 & $(\mathrm{Na})$ & 230 & $(\mathrm{Cr})$ \\
\hline
\end{tabular}


Table 3.12 contd.

$\begin{array}{lclcllll}\text { T-111 (untreated) } & 2670 & \text { (Na) } & 1620 & \text { (P) } & 410 & \text { (S) } \\ \text { T-111 (SW) } & 810 & \text { (P) } & 410 & (\mathrm{~S}) & 280 & (\mathrm{Cr}) \\ \text { T-111 (SW+CL) } & 450 & \text { (P) } & 410 & (\mathrm{~S}) & 190 & (\mathrm{Na})\end{array}$

(a) $\mathrm{SW}=$ washing with inhibited water only; $\mathrm{SW}+\mathrm{CL}=$ caustic leaching plus sludge washing (i.e., the baseline process).

(b) Using the value of $89 \%$ removal of $P$ that was obtained by IC, the limiting component for T-104 would be $\mathrm{Na}$, and 980 canisters would result. The next limiting component would be P ( 590 canisters), and the third limiting component would be $\mathrm{Cr}(230$ canisters).

components that yield the maximun number of glass canisters are reported in Table 3.12 for each sludge.

Two caveats must be placed upon the canister numbers in Table 3.12. First, a certain set of glass specifications was used in the calculations; modified glass specifications could result in modifications to the values presented in Table 3.12. For example, the $P$ limit used in a recent study (Lambert and Kim 1994) is threefold higher than that used by Swanson (1993); incorporation of this change would give a threefold reduction in the P-limited canister count values. Second, the canister numbers are based on processing on a tank-by-tank basis. Implementation of waste-blending schemes could likely reduce the number of glass canisters required.

Several trends are apparent from Table 3.12. The glass-volume-limiting components for the untreated sludges are primarily $\mathrm{Na}$ and $\mathrm{P}$. Only in the case of $\mathrm{C}-103$, which possesses an unusually low concentration of $\mathrm{Na}$, is another element (Al) the limiting component. Sludge washing and caustic leaching are of wide and varying effectiveness in reducing the number of glass canisters formed upon vitrifying the treated solids. For some sludges, sludge washing and caustic leaching are very effective at reducing the amount of glass canisters that would be needed to vitrify the residual solids. For B-111 sludge, for example, the HLW volume should be decreased by a factor $>10$ if the baseline process in implemented. Tank BX-107 and, to a lesser extent, T-111, should also experience large decreases in HLW volume. On the other 
hand, with the four other sludges examined in this work, C-103, S-104, SY-103, and T-104, a decrease of only a factor of 2 in the amount of $\mathrm{HLW}$ required after sludge washing and caustic leaching is indicated. However, the amount of HLW glass required for vitrifying the leached $\mathrm{T}-104$ solids is dominated by the amount of $\mathrm{P}$ remaining in the residual solids. As noted above, that number is suspect, and if it is in fact sufficiently reduced such that $\mathrm{Na}$ becomes the limiting agent, a decrease in glass of between a factor of 4 and 5 would result.

The reasons for the relatively poor performance in glass reduction for the four sludges noted above are unique to each sludge type. The case of T-104 was described previously. In the case of $\mathrm{C}-103$, the final limiting component is Al. However, more effective Al dissolution would have a relatively small impact, since the amount of $\mathrm{Fe}$ remaining in the residual solids results in almost the same number of glass canisters. Any large additional decreases in glass from vitrifying treated $\mathrm{C}-103$ solids would require effective removal of Fe from the solids or solids dissolution coupled with a radionuclide separation scheme.

Tank S-104 and SY-103 sludges are both different from each other and from the other sludges in respect to what determines the amount of glass formed by vitrifying these solids. In the case of S-104, poor dissolution of Al determines both the poor reduction in glass volume and the relatively high total number of canisters required. More effective $\mathrm{Al}$ and $\mathrm{Na}$ removal could further reduce the number of glass canisters by an order of magnitude. With SY-103, more effective $\mathrm{Cr}$ dissolution could reduce the number of glass canisters by more than a factor of 20 , and, if coupled with more effective Al dissolution, a further reduction of approximately two orders of magnitude might be possible.

\subsection{Conclusion}

The effectiveness of sludge washing and caustic leaching in reducing the number of HLW glass canisters required to immobilize the treated solids varies greatly from tank-to-tank. Transuranic and $\mathrm{Sr}$ dissolutions are minimal in all cases and particularly small, unless the sludge is likely to contain metal complexing agents. Enhanced $\mathrm{Cr}, \mathrm{P}, \mathrm{Al}$, and perhaps $\mathrm{Fe}$ 
dissolution, when waste immobilization is considered on a tank-by-tank basis, could have a major impact in the amount of glass produced over and above the current baseline sludge washing and caustic leaching scheme. Finally, the current planning assumptions regarding sludge washing and caustic leaching give values that are generally close to the experimental results to date, even though the planning assumptions appear to have relatively little chemical basis. 


\subsection{References}

10 CFR 61. 1988. U.S. Nuclear Regulatory Commission, "Licensing Requirements for Land Disposal of Radioactive Waste." U.S. Code of Federal Regulations.

Colton, N. G. 1995. Sludge Pretreatment Chemistry Evaluation: Enhanced Sludge Washing Separation Factors. PNL-10512, Pacific Northwest Laboratory, Richland, Washington.

Ecology, EPA, and DOE. 1994. Hanford Federal Facility Agreement and Consent Order. Washington State Department of Ecology, U.S. Environmental Protection Agency, and U.S. Department of Energy, Olympia, Washington.

Hanlon, B.M. 1995. Tank Farm Surveillance and Waste Status Summary Report for May, 1995. WHC-EP-0182-86, Westinghouse Hanford Company, Richland, Washington.

Hill, J. G., G. S. Anderson, and B. C. Simpson. 1995. The Sort on Radioactive Waste Type Model: A Method to Sort Single-Shell Tanks into Characteristic Groups. PNL-9814 Rev. 2, Pacific Northwest Laboratory, Richland, Washington.

Lambert, S. L., and D. S. Kim. 1994. Tank Waste Remediation System High-Level Waste Feed Processability Assessment Report. WHC-SP-1143, Westinghouse Hanford Company, Richland, Washington.

Lumetta, G. J., B. M. Rapko, and N. G. Colton. 1994. Washing and Caustic Leaching of Hanford Tank Sludges. PNL-SA-23598, Pacific Northwest Laboratory, Richland, Washington.

Lumetta, G. J., and J. L. Swanson. 1993a. Pretreatment of Neutralized Cladding Removal Waste (NCRW) Sludge - Results of FY 1991 Studies. PNL-8536. Pacific Northwest Laboratory, Richland, Washington.

Lumetta, G. J., and J. L. Swanson. 1993b. Pretreatment of Plutonium Finishing Plant (PFP) Sludge: Report for the Period October 1990 - March 1992. PNL-8601. Pacific Northwest Laboratory, Richland, Washington.

Lumetta, G. J., J. L. Swanson, and S. A. Barker. 1995. "Process Chemistry For The Pretreatment of Hanford Tank Wastes." Chemical Pretreatment of Nuclear Waste for Disposal. W. W. Schulz and E. P. Horwitz, eds., Plenum Press, New York.

Lumetta, G. J., and B. M. Rapko. 1994. Washing and Alkaline Leaching of Hanford Tank Sludges: A Status Report. PNL-10078. Pacific Northwest Laboratory, Richland, Washington. 
Lumetta, G. J., B. M. Rapko, M. J. Wagner, C. D. Carlson, and R. J. Barrington. 1994. Sludge Treatment and Extraction Technology Development: Results of FY 1993 Studies. PNL9387. Pacific Northwest Laboratory, Richland, Washington.

Orme, R. M. 1994. TWRS Process Flowsheet. WHC-SD-WM-TI-613, Westinghouse Hanford Company, Richland, Washington.

Rai, D., B. M. Sass, and D. A. Moore. 1987. "Chromium(III) Hydrolysis Constants and Solubility of Chromium(III) Hydroxide." Inorg. Chem., Volume 26, pp. 345-349.

Straalsund, J. L., J. L. Swanson, E. G. Baker, J. J. Holmes, E. O. Jones, and W. L. Kuhn. 1992. Clean Option: An Alternative Strategy for Hanford Tank Remediation. Volume 1. Overview. PNL-8388 Vol. 1, Pacific Northwest Laboratory, Richland, Washington.

Swanson, J. L. 1993. Clean Option: An Alternative Strategy for Hanford Tank Waste Remediation. Volume 2: Detailed Description of First Example Flowsheet. PNL-8388 Vol 2, Pacific Northwest Laboratory, Richland, Washington.

Temer, D. J., and R. Villareal. 1995. Sludge Washing and Alkaline Leaching Tests on Actual Hanford Tank Sludge: A Status Report. LAUR-95-2070, Los Alamos National Laboratory, Los Alamos, New Mexico.

Weber, E. J. 1982. Aluminum Hydroxide Dissolution in Synthetic Sludges. DP-1617, Savannah River Laboratory, Aiken, South Carolina. 


\section{Appendix A}

Results from the Tank B-111 Sludge

Washing and Caustic Leaching Test 


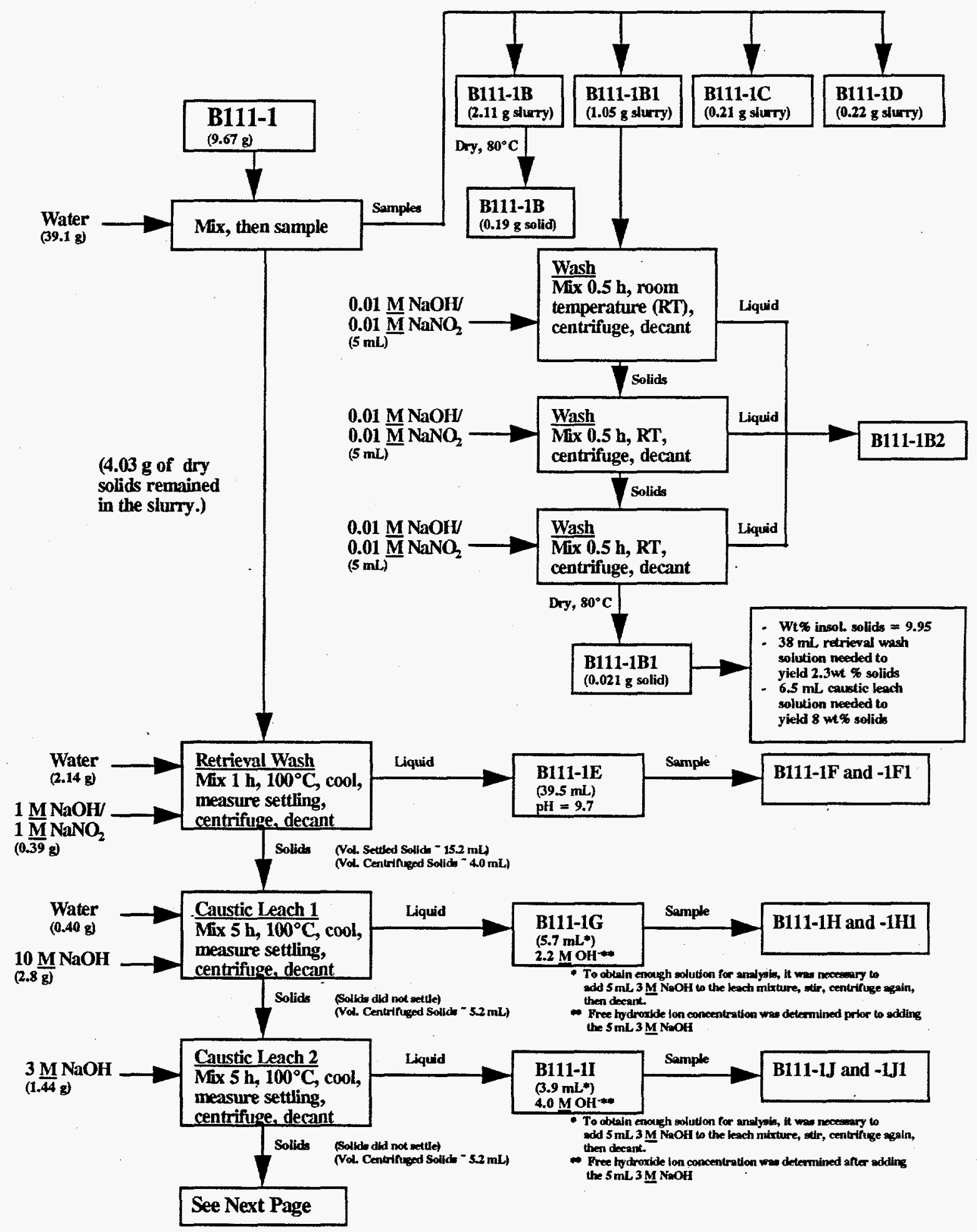

Figure A.1. Schematic of B-111 Sludge Washing and Caustic Leaching Test 


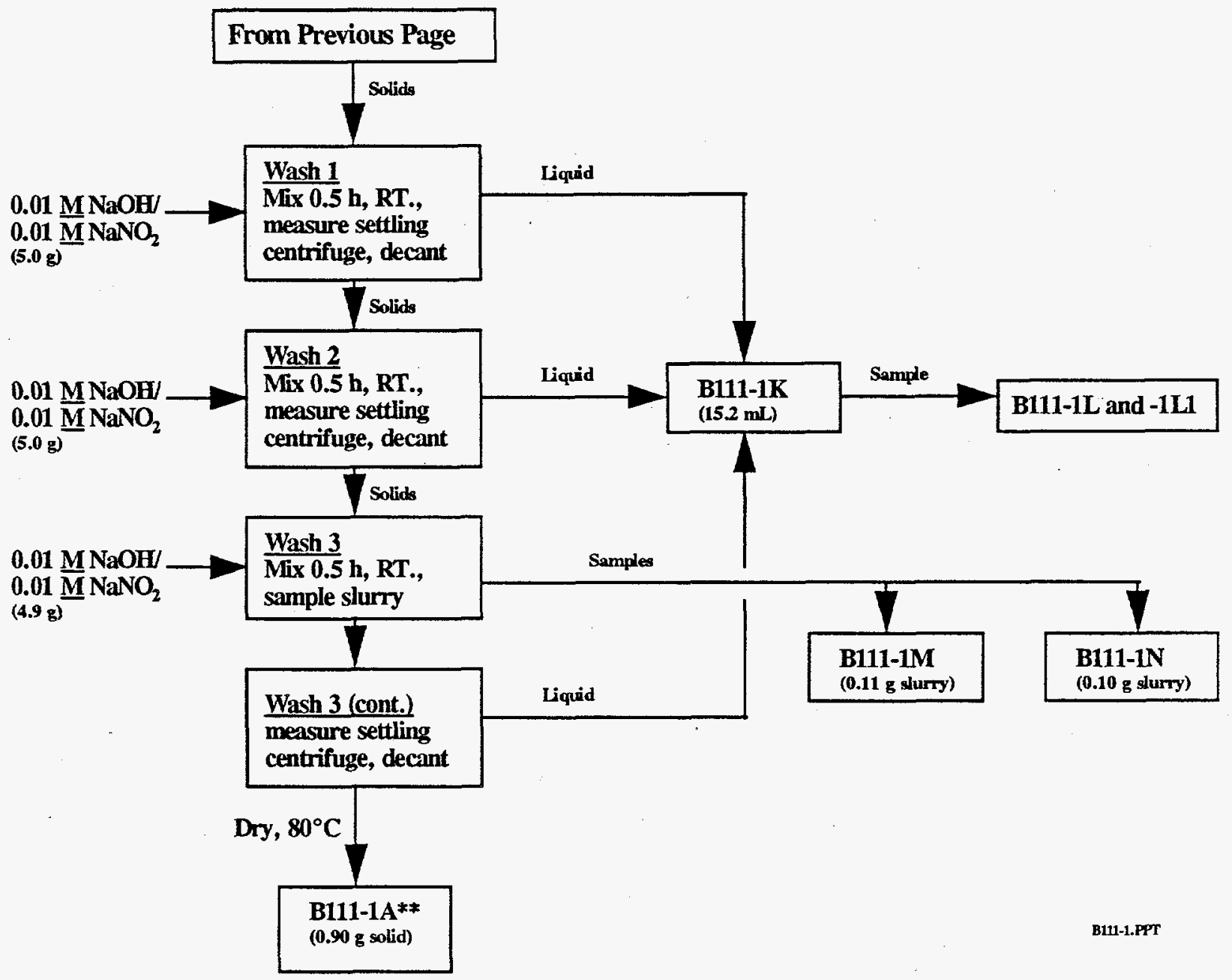

Figure A.1. (contd.) 
Table A.1. Concentrations of the Nonradioactive Sludge Components in the Various Process Solutions From the B-111 Test

\begin{tabular}{|c|c|c|c|c|c|}
\hline \multirow[b]{2}{*}{ Component } & \multirow[b]{2}{*}{$\begin{array}{c}\text { Detection } \\
\text { Limit, } \mu \mathrm{g} / \mathrm{mL} \\
\end{array}$} & \multicolumn{4}{|c|}{ Concentration, $\mu \mathrm{g} / \mathrm{mL}^{(\mathrm{a})}$} \\
\hline & & $\begin{array}{l}\text { Retrieval Solution } \\
\text { (E) }\end{array}$ & $\begin{array}{c}\text { First Caustic } \\
\text { Leach (G) }\end{array}$ & $\begin{array}{l}\text { Second Caustic } \\
\text { Leach (D) }\end{array}$ & Wash $(\mathrm{K})$ \\
\hline $\mathrm{Ag}$ & 0.17 & 0 & 0 & 0 & 0 \\
\hline Al & 0.85 & 0 & 17.85 & 16 & 8.5 \\
\hline As & 1.7 & 0 & 0 & 0 & 0 \\
\hline $\mathbf{B}$ & 0.34 & 3.4 & 4.76 & 3.2 & 0.60 \\
\hline Ba & 0.17 & 0 & 0 & 0 & 0 \\
\hline $\mathrm{Be}$ & 0.08 & 0 & 0. & 0 & 0 \\
\hline $\mathrm{Bi}$ & 1.7 & 0 & 20.4 & 124.8 & 8.5 \\
\hline $\mathrm{Ca}$ & 0.85 & 17.85 & 8.5 & 8 & 6.0 \\
\hline $\mathrm{Cd}$ & 0.17 & 0 & 0 & 0 & 0 \\
\hline $\mathrm{Ce}$ & 1.7 & 0 & 0 & 0 & 0 \\
\hline Co & 0.17 & 0 & 0 & 0 & 0 \\
\hline $\mathrm{Cr}$ & 0.34 & 71 & 31 & 176 & 41 \\
\hline $\mathrm{Cu}$ & 0.17 & 0.77 & 9.35 & 54.40 & 2.13 \\
\hline Dy & 0.34 & 0 & 0 & 0 & 0 \\
\hline Eu & 0.17 & 0 & 0 & 0 & 0 \\
\hline $\mathrm{Fe}$ & 0.17 & 0.43 & 16.15 & 28.80 & 2.47 \\
\hline Gd & 3.4 & 0 & 0 & 0 & 0 \\
\hline $\mathrm{K}$ & 25.5 & 85 & 170 & 80 & 0 \\
\hline $\mathrm{La}$ & 0.51 & 0 & 0 & 0 & 0 \\
\hline $\mathrm{Li}$ & 0.34 & 0 & 0 & 0 & 0 \\
\hline $\mathbf{M g}$ & 1.7 & 0 & 0 & 0 & 0 \\
\hline Mn & 0.08 & 0 & 0 & 0 & 0 \\
\hline Mo & 0.34 & 9.35 & 2.55 & 1.6 & 0 \\
\hline $\mathrm{Na}$ & 17 & 21250 & 76500 & 107200 & 33150 \\
\hline Nd & 0.51 & 0 & 0 & 0 & 0 \\
\hline $\mathrm{Ni}$ & 0.51 & 0 & 0 & 0 & 3.4 \\
\hline $\mathbf{P}$ & 1.7 & 1870 & 1785 & 1136 & 4420 \\
\hline $\mathrm{Pb}$ & 0.85 & 0 & 29.75 & 120 & 7.65 \\
\hline Pd & 2.55 & 0 & 0 & 0 & 0 \\
\hline $\mathbf{R h}$ & 1.7 & 0 & 0 & 0 & 0 \\
\hline $\mathbf{R u}$ & 1.7 & 0 & 0 & 0 & 0 \\
\hline $\mathbf{S b}$ & 0.85 & 0 & 0 & 0 & 0 \\
\hline $\mathrm{Se}$ & 1.7 & 0 & 0 & 0 & 0 \\
\hline $\mathrm{Si}$ & 0.85 & 74.8 & 3485 & 3840 & 935 \\
\hline Sn & 17 & 0 & 0 & 0 & 0 \\
\hline Sr & 0.08 & 0 & 0 & 0 & 0 \\
\hline $\mathrm{Te}$ & 3.4 & 0 & 0 & 0 & 0 \\
\hline Th & 17 & 0 & 0 & 0 & 0 \\
\hline $\mathbf{T i}$ & 0.08 & 0 & 0 & 0 & 0 \\
\hline $\mathrm{T} 1$ & 8.5 & 0 & 0 & 0 & 0 \\
\hline$U$ & 0.00003 & 33.92 & 5.91 & 10.18 & 1.60 \\
\hline $\mathrm{V}$ & 0.17 & 0 & 0.34 & 0 & 0 \\
\hline w & 1.7 & 0 & 0 & 0 & 0 \\
\hline $\mathrm{Y}$ & 0.17 & 0 & 0 & 0 & 0 \\
\hline $\mathrm{Zn}$ & 0.34 & 0 & 23.8 & 48 & 6.97 \\
\hline $\mathrm{Zr}$ & 0.17 & 0 & 0 & 0 & 0 \\
\hline $\mathrm{NO}_{3}^{-}$ & 500 & 18900 & 5900 & 3500 & 680 \\
\hline $\mathrm{NO}_{2}^{-}$ & 500 & 11900 & 4100 & 2500 & 800 \\
\hline $\mathrm{PO}_{4}^{3-}$ & 100 & 5300 & 5700 & 3500 & 13000 \\
\hline $\mathrm{SO}_{4}^{2-}$ & 50 & 2890 & 1000 & 590 & 130 \\
\hline $\mathbf{F}^{-}$ & 25 & 270 & 0 & 0 & 0 \\
\hline $\mathrm{Cl}^{\circ}$ & 25 & 300 & 100 & 60 & 0 \\
\hline $\mathrm{Br}$ & 50 & 0 & $<25$ & $<25$ & $<25$ \\
\hline
\end{tabular}

(a) Zero values indicate the analyte was below the detection limit.

\section{A.3}


Table A.3. Distribution of the Nonradioactive Sludge Components Between the Various Process Streams From the B-111 Test

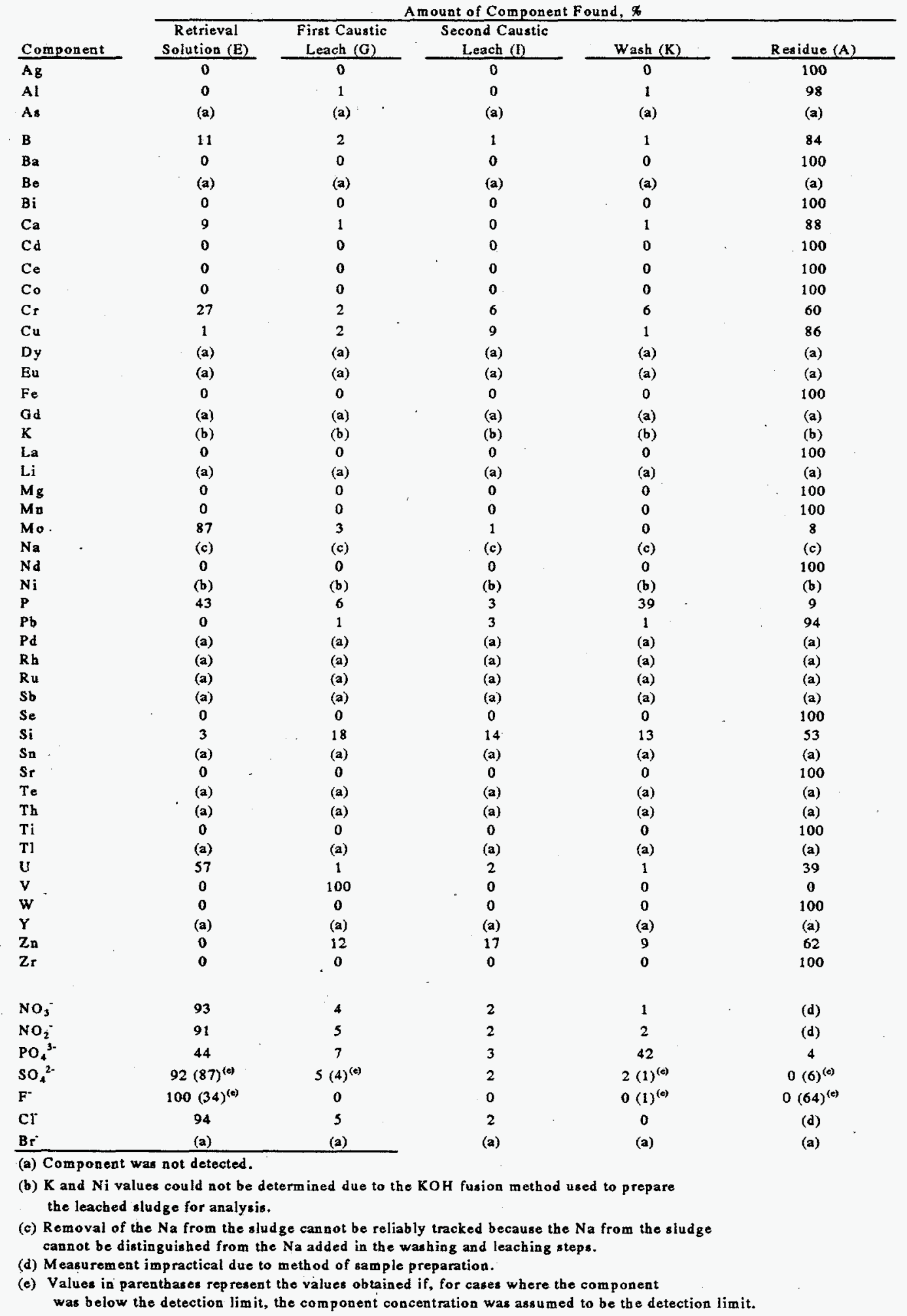


Table A.4. Mass Balance for Nonradioactive Sludge Components From the B-111 Test

Concentration in Dried Sludge, g/g Sludge

\begin{tabular}{|c|c|c|c|}
\hline \multirow[b]{2}{*}{ Component } & & & \multirow[b]{2}{*}{ Recovery, $\%$} \\
\hline & Direct Analysis & Summation Method & \\
\hline $\mathrm{Ag}$ & $<9.00 \mathrm{E}-05$ & $1.12 \mathrm{E}-05$ & \\
\hline Al & $3.00 \mathrm{E}-03$ & $4.11 \mathrm{E}-03$ & 137 \\
\hline As & $<7.00 \mathrm{E}-04$ & & \\
\hline B & $2.00 \mathrm{E}-03$ & $2.92 \mathrm{E}-04$ & 15 \\
\hline Ba & $<9.00 \mathrm{E}-05$ & $6.50 \mathrm{E}-05$ & \\
\hline $\mathrm{Be}$ & $<4.00 \mathrm{E}-05$ & & \\
\hline$B \mathbf{i}$ & $5.20 \mathrm{E}-02$ & $4.05 \mathrm{E}-02$ & 78 \\
\hline $\mathrm{Ca}$ & $1.00 \mathrm{E}-03$ & $1.85 \mathrm{E}-03$ & 185 \\
\hline $\mathrm{Cd}$ & $<9.00 \mathrm{E}-05$ & $6.72 E-06$ & \\
\hline $\mathrm{Ce}$ & $<7.00 \mathrm{E}-04$ & $4.48 E-05$ & \\
\hline Co & $<9.00 \mathrm{E}-05$ & $8.97 E-06$ & \\
\hline $\mathrm{Cr}_{\mathrm{r}}$ & $3.10 \mathrm{E}-03$ & $2.64 \mathrm{E}-03$ & 85 \\
\hline $\mathrm{Cu}$ & $4.00 \mathrm{E}-04$ & $5.97 \mathrm{E}-04$ & 149 \\
\hline Dy & $<2.00 \mathrm{E}-04$ & & \\
\hline Eu & $<9.00 \mathrm{E}-05$ & & \\
\hline $\mathrm{Fe}$ & $4.60 \mathrm{E}-02$ & $4.04 \mathrm{E}-02$ & 88 \\
\hline Gd & $<2.00 \mathrm{E}-03$ & & \\
\hline $\mathbf{x}$ & (b) & (b) & \\
\hline La & $<3.00 \mathrm{E}-04$ & $1.34 \mathrm{E}-05$ & \\
\hline $\mathrm{Li}$ & $<2.00 \mathrm{E}-04$ & & \\
\hline $\mathbf{M g}$ & $<7.00 \mathrm{E}-04$ & $5.38 \mathrm{E}-04$ & \\
\hline $\mathbf{M n}$ & $4.00 \mathrm{E}-04$ & $2.22 \mathrm{E}-04$ & 55 \\
\hline Mo & $<2.00 \mathrm{E} \cdot 04$ & $1.06 \mathrm{E}-04$ & \\
\hline $\mathrm{Na}$ & (c) & & \\
\hline Nd & $<3.00 \mathrm{E}-04$ & $4.48 E-05$ & \\
\hline $\mathbf{N i}$ & (b) & (b) & \\
\hline $\mathbf{P}$ & $4.10 \mathrm{E}-02$ & $4.22 \mathrm{E}-02$ & 103 \\
\hline $\mathbf{P b}$ & $4.00 \mathrm{E}-03$ & $3.33 \mathrm{E}-03$ & 83 \\
\hline$P d$ & $<1.00 \mathrm{E} \cdot 03$ & & \\
\hline $\mathbf{R h}$ & $<9.00 \mathrm{E}-04$ & & \\
\hline Ru & $<9.00 \mathrm{E}-04$ & & \\
\hline Sb & $<4.00 \mathrm{E}-04$ & & \\
\hline Se & $<7.00$ E-04 & $6.72 \mathrm{E}-05$ & \\
\hline $\mathbf{S i}$ & 2.60E-02 & $2.75 \mathrm{E}-02$ & 106 \\
\hline Sn & $<9.00 \mathrm{E}-03$ & & \\
\hline $\mathrm{Sr}$ & $5.80 \mathrm{E}-04$ & $4.71 \mathrm{E}-04$ & 81 \\
\hline $\mathrm{Te}$ & $<2.00 \mathrm{E}-03$ & & \\
\hline Th & $<7.00 \mathrm{E}-03$ & & \\
\hline $\mathrm{T}_{\mathrm{i}}$ & $9.00 \mathrm{E}-05$ & $6.72 \mathrm{E}-05$ & 75 \\
\hline $\mathrm{T} 1$ & $<4.00 \mathrm{E}-03$ & & \\
\hline $\mathbf{U}$ & $6.00 \mathrm{E}-04$ & $5.86 \mathrm{E}-04$ & 98 \\
\hline v & $<9.00 \mathrm{E}-05$ & $4.81 \mathrm{E}-07$ & \\
\hline $\mathbf{w}$ & $<7.00 \mathrm{E}-04$ & $4.48 \mathrm{E}-05$ & \\
\hline $\mathbf{Y}$ & $<9.00 \mathrm{E}-05$ & & \\
\hline$Z_{n}$ & $<2.00 \mathrm{E}-04$ & $2.79 \mathrm{E}-04$ & \\
\hline$Z_{r}$ & $<9.00 \mathrm{E} .05$ & $2.24 \mathrm{E}-05$ & \\
\hline $\mathrm{NO}_{3}^{-}$ & (d) & $1.99 \mathrm{E}-01$ & \\
\hline $\mathrm{NO}_{2}^{-}$ & (d) & $1.28 \mathrm{E}-01$ & \\
\hline $\mathrm{PO}_{4}{ }^{3-}$ & $1.20 \mathrm{E}-01$ & $1.17 \mathrm{E}-01$ & 97 \\
\hline $\mathrm{SO}_{4}^{2-}$ & $4.00 \mathrm{E}-02$ & $3.08 \mathrm{E}-02$ & 77 \\
\hline$F^{-}$ & $<3.67 \mathrm{E}-02$ & $2.64 \mathrm{E}-03$ & \\
\hline $\begin{array}{l}\mathrm{Cr}^{-} \\
\mathrm{Br}^{-}\end{array}$ & (d) & $3.14 \mathrm{E}-03$ & \\
\hline $\begin{array}{l}\text { (a) Blank sp: } \\
\text { (b) } \mathrm{K} \text { and } \mathrm{N} \\
\text { used to } \\
\text { (c) Reliable } \\
\text { (d) M easurer }\end{array}$ & $\begin{array}{l}\text { icate values belo } \\
\text { could not be det } \\
\text { the solids for ans } \\
\text { ot available due } \\
\text { apractical due to }\end{array}$ & $\begin{array}{l}\text { etion limits. } \\
\text { te to the KOH fusion } \\
\text { encountered in anal } \\
\text { sample preparation. }\end{array}$ & ure. \\
\hline
\end{tabular}

A. 6 
Table A.5. Concentrations of the Radioactive Sludge Components in the Various Process Streams From the B-111 Test

Concentration, $\mu \mathrm{Ci} / \mathrm{mL}$

\begin{tabular}{|c|c|c|c|c|}
\hline \multirow[b]{2}{*}{ Component } & \multicolumn{4}{|c|}{ Concentration, $\mu \mathrm{Ci} / \mathrm{mL}$} \\
\hline & $\begin{array}{c}\text { Retrieval } \\
\text { Solution (E) }\end{array}$ & $\begin{array}{l}\text { First Caustic } \\
\text { Leach (G) }\end{array}$ & $\begin{array}{l}\text { Second Caustic } \\
\text { Leach (1) }\end{array}$ & Wash (K) \\
\hline Total Alpha & $<2.55 \mathrm{E}-05$ & $<2.55 \mathrm{E}-05$ & $<4.8 \mathrm{E}-05$ & $<2.55 \mathrm{E}-05$ \\
\hline${ }^{239,240} \mathrm{Pu}$ & $\mathrm{ND}^{(\mathrm{a})}$ & ND & ND & ND \\
\hline${ }^{241} \mathrm{Am}+{ }^{238} \mathrm{Pu}$ & ND & ND & ND & ND \\
\hline${ }^{241} \mathrm{Am}(\gamma)$ & $<4.00 \mathrm{E}-04$ & $<6.00 \mathrm{E}-03$ & $<4.00 \mathrm{E}-04$ & $<3.00 \mathrm{E}-04$ \\
\hline${ }^{137} \mathrm{Cs}$ & $2.02 \mathrm{E}+01$ & $6.84 E+01$ & $4.02 E+01$ & $8.76 \mathrm{E}+00$ \\
\hline${ }^{90} \mathrm{Sr}$ & 8.67E-04 & $6.32 \mathrm{E}-03$ & $2.22 \mathrm{E}-02$ & $1.14 \mathrm{E}-02$ \\
\hline \multirow[t]{2}{*}{${ }^{99} \mathrm{Tc}$} & $3.04 \mathrm{E}-02$ & $9.18 \mathrm{E}-03$ & $4.82 \mathrm{E}-03$ & $1.16 \mathrm{E}-03$ \\
\hline & \multicolumn{3}{|c|}{ Concentration, $\mu \mathrm{Ci} / \mathrm{g}$} & \\
\hline Component & & Residue & & \\
\hline Total Alpha & & $2.90 \mathrm{E}+\infty 0$ & & \\
\hline${ }^{239,240} \mathrm{Pu}$ & & $1.32 E+\infty$ & & \\
\hline${ }^{241} \mathrm{Am}+{ }^{238} \mathrm{Pu}$ & & $7.74 \mathrm{E}-01$ & & \\
\hline${ }^{241} \mathrm{Am}(\gamma)$ & & $1.01 E+\infty$ & & \\
\hline${ }^{137} \mathrm{Cs}$ & & $7.97 \mathrm{E}+01$ & & \\
\hline${ }^{90} \mathrm{Sr}$ & & $3.03 \mathrm{E}+03$ & & \\
\hline${ }^{99} \mathrm{Tc}$ & & $1.81 E-03$ & & \\
\hline
\end{tabular}

(a) $\mathrm{ND}=$ Not Determined. The low total alpha activity made these separations impractical. 
Table A.6. Distribution of the Radioactive Sludge Components Between the Various Process Streams From the B-111 Test

\begin{tabular}{|c|c|c|c|c|c|}
\hline \multirow[b]{2}{*}{ Component } & \multicolumn{5}{|c|}{ Amount of Component Found, \% } \\
\hline & $\begin{array}{c}\text { Retrieval } \\
\text { Solution (E) }\end{array}$ & $\begin{array}{l}\text { First Caustic } \\
\text { Leach }(G)\end{array}$ & $\begin{array}{l}\text { Second Caustic } \\
\text { Leach (I) }\end{array}$ & Wash (K) & Residue (A) \\
\hline Total Alpha & 0 & 0 & 0 & 0 & 100 \\
\hline${ }^{239,240} \mathrm{Pu}$ & (a) & (a) & (a) & (a) & 100 \\
\hline${ }^{241} \mathrm{Am}+{ }^{238} \mathrm{Pu}$ & (a) & (a) & (a) & (a) & 100 \\
\hline${ }^{241} \mathrm{Am}(\gamma)$ & 0 & 0 & 0 & 0 & 100 \\
\hline${ }^{137} \mathrm{Cs}$ & 52 & 25 & 10 & 9 & 5 \\
\hline${ }^{90} \mathrm{Sr}$ & 0 & 0 & 0 & 0 & 100 \\
\hline${ }^{99} \mathrm{Tc}$ & 93 & 4 & 1 & 1 & 0 \\
\hline
\end{tabular}

(a) Not determined due to the low total alpha activity of the samples.

Table A.7. Mass Balance for Radioactive Sludge Components From the B-111 Test

\begin{tabular}{l} 
Component \\
\hline Total Alpha \\
${ }^{239,240} \mathrm{Pu}$ \\
${ }^{241} \mathrm{Am}+{ }^{238} \mathrm{Pu}$ \\
${ }^{241} \mathrm{Am}(\gamma)$ \\
${ }^{137} \mathrm{Cs}$ \\
${ }^{90} \mathrm{Sr}$ \\
${ }^{99} \mathrm{Tc}$
\end{tabular}

Concentration in Dried Sludge, $\mu \mathrm{Ci} / \mathrm{g}$

\begin{tabular}{|c|c|c|}
\hline Direct Analysis & Summation Method & Recovery, \% \\
\hline $4.08 \mathrm{E}-01$ & $6.50 \mathrm{E}-01$ & 159 \\
\hline $2.82 \mathrm{E}-01$ & $2.95 \mathrm{E}-01$ & 105 \\
\hline $1.26 \mathrm{E}-01$ & $1.73 \mathrm{E}-01$ & 138 \\
\hline $2.65 \mathrm{E}-01$ & $2.25 \mathrm{E}-01$ & 85 \\
\hline $3.72 \mathrm{E}+02$ & $3.85 \mathrm{E}+02$ & 103 \\
\hline $6.46 \mathrm{E}+02$ & $6.78 \mathrm{E}+02$ & 105 \\
\hline $2.24 \mathrm{E}-01$ & $3.20 \mathrm{E}-01$ & 143 \\
\hline
\end{tabular}



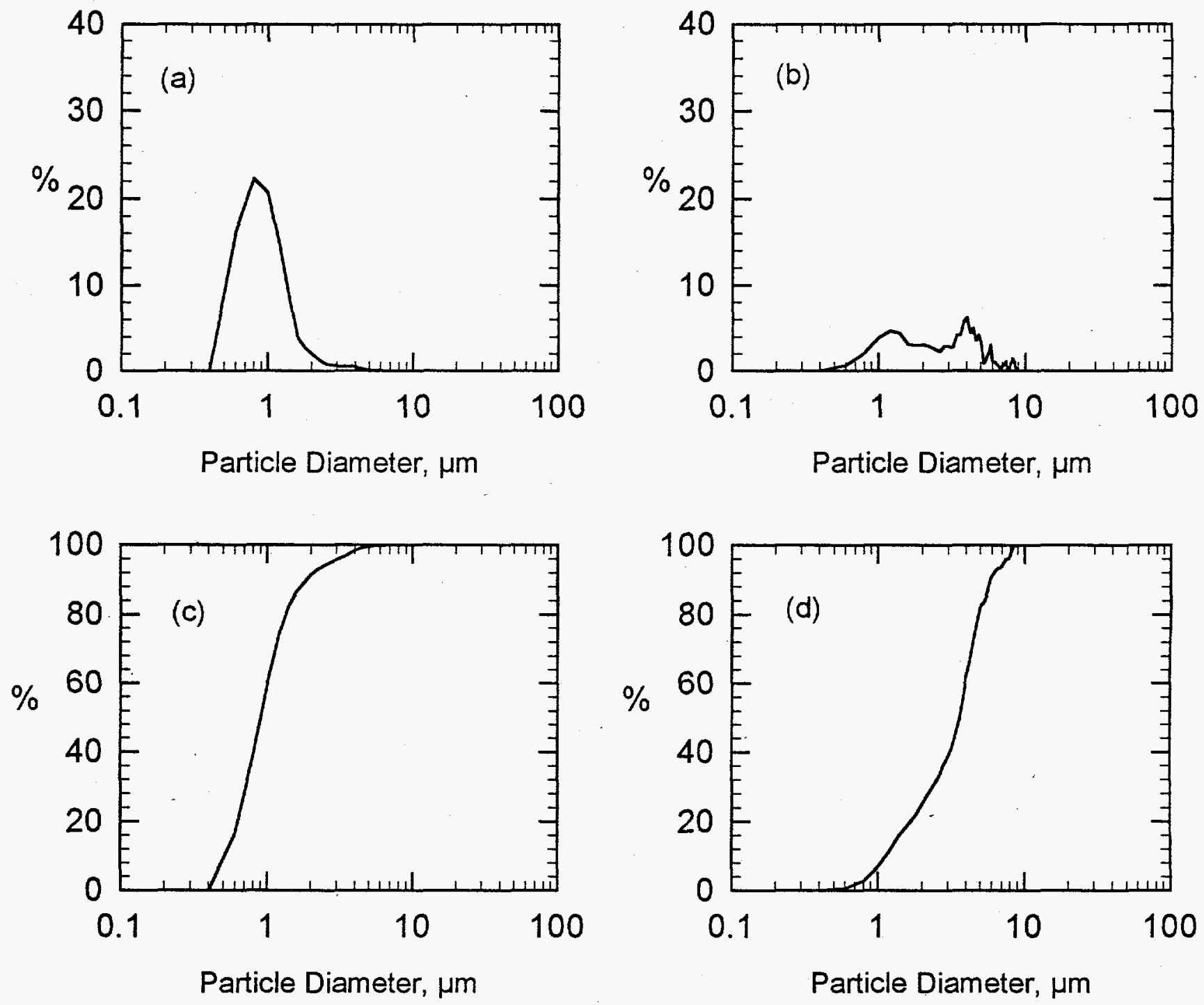

B111-C.SPW

Figure A.2. Particle-Size Data for Untreated B-111 Sludge: a) Probability-Number Density Graph, b) Probability-Volume Density Graph, c) Probability-Number Distribution Graph, and d) Probability-Volume Distribution Graph. 

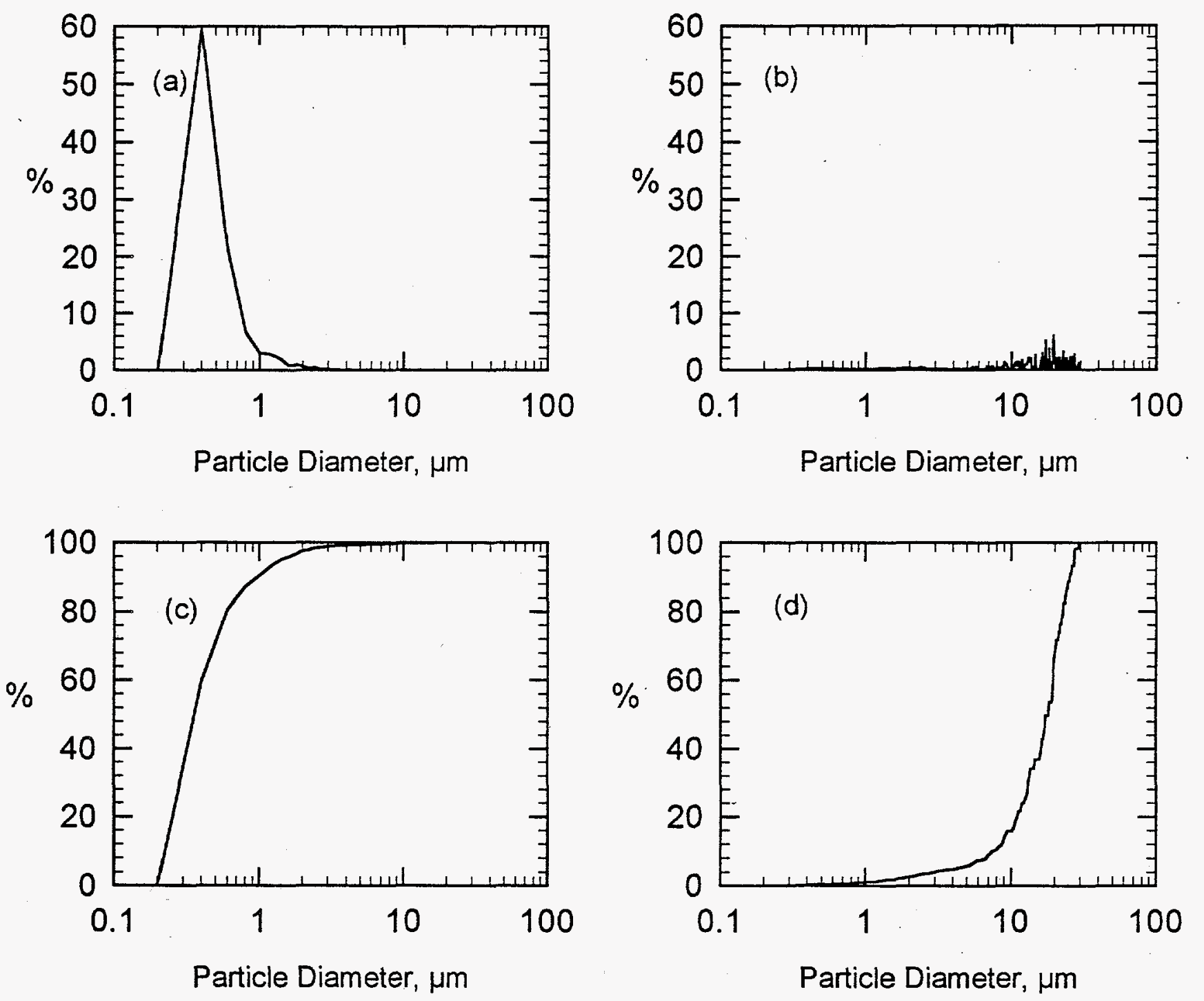

B111-M.SPW

Figure A.3. Particle-Size Data for Treated B-111 Sludge: a) Probability-Number Density Graph, b) Probability-Volume Density Graph, c) Probability-Number Distribution Graph, and d) Probability-Volume Distribution Graph. 
Appendix B

Results from the Tank BX-107 Sludge

Washing and Caustic Leaching Test 


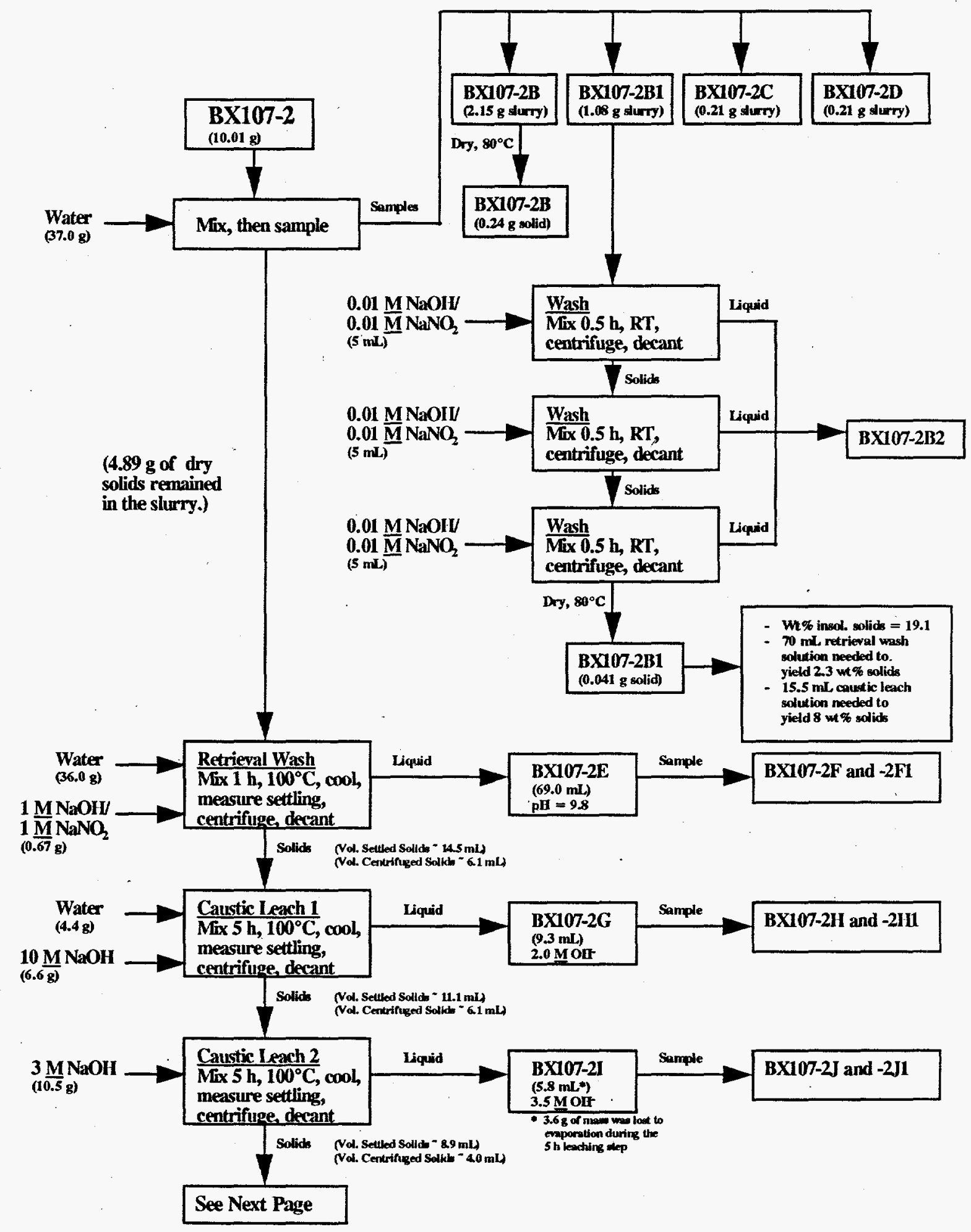

Figure B.1. Schematic of BX-107 Sludge Washing and Caustic Leaching Test

B. 1 


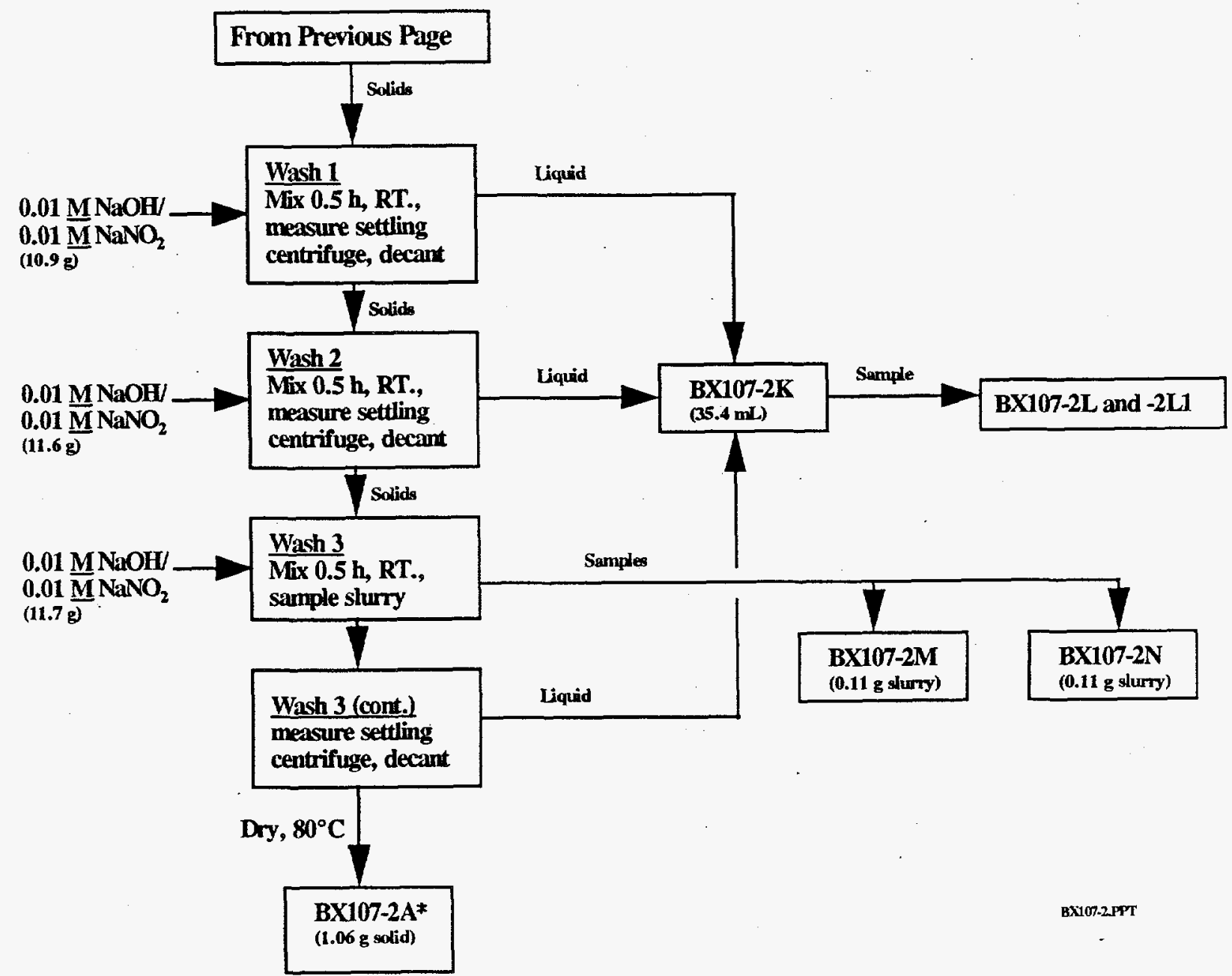

Figure B.1. (contd.) 
Table B.1. Concentrations of the Nonradioactive Sludge Components in the Various Process Solutions From the BX-107 Test

\begin{tabular}{|c|c|c|c|c|c|}
\hline \multirow[b]{2}{*}{ Component } & \multirow[b]{2}{*}{$\begin{array}{c}\text { Detection } \\
\text { Limit. } \mu \mathrm{g} / \mathrm{mL}\end{array}$} & \multicolumn{4}{|c|}{ Concentration, $\mu \mathrm{g} / \mathrm{mL}^{(\mathbf{a})}$} \\
\hline & & $\begin{array}{l}\text { Retrieval Solution } \\
\text { (E) }\end{array}$ & $\begin{array}{c}\text { First Caustic } \\
\text { Leach }(\mathrm{G})\end{array}$ & $\begin{array}{l}\text { Second Caustic } \\
\text { Leach (I) }\end{array}$ & Wash $(\mathrm{K})$ \\
\hline $\mathrm{Ag}$ & 0.43 & 0 & 0 & 0 & 0 \\
\hline A1 & 2.6 & 26.4 & 7225 & 2720 & 272 \\
\hline As & 3.4 & 0 & 17 & 6 & 0 \\
\hline B & 0.85 & 3.4 & 2.6 & 0 & 0 \\
\hline $\mathrm{Ba}$ & 0.43 & 0 & 0 & 0 & 0 \\
\hline $\mathrm{Be}$ & 0.26 & 0 & 0 & 0 & 0 \\
\hline $\mathrm{Bi}$ & 4.3 & 0 & 17 & 34 & 0 \\
\hline $\mathrm{Ca}$ & 2.6 & 4.3 & 8.5 & 0 & 6 \\
\hline $\mathrm{Cd}$ & 0.43 & 0 & 0 & 0 & 0 \\
\hline $\mathrm{Ce}$ & 3.4 & 0 & 0 & 0 & 0 \\
\hline Co & 0.43 & 0 & 0 & 0 & 0 \\
\hline $\mathrm{Cr}$ & 0.85 & 19.6 & 18.7 & 38.3 & 4.3 \\
\hline $\mathrm{Cu}$ & 0.43 & 0 & 0 & 0.85 & 0 \\
\hline Dy & 0.85 & 0 & 0 & 0 & 0 \\
\hline $\mathrm{Eu}$ & 0.43 & 0 & 0 & 0 & 0 \\
\hline $\mathrm{Fe}$ & 0.43 & 3.4 & 4.3 & 4.4 & 0 \\
\hline Gd & 8.5 & 0 & 0 & 0 & 0 \\
\hline $\mathbf{K}$ & 68 & 76.5 & 0 & 0 & 0 \\
\hline $\mathrm{La}$ & 1.7 & 0 & 0 & 0 & 0 \\
\hline $\mathrm{Li}$ & 0.85 & 0 & 0 & 0 & 0 \\
\hline $\mathbf{M g}$ & 3.4 & 0 & 0 & 0 & 0 \\
\hline $\mathrm{Mn}$ & 0.26 & 0.6 & 0.43 & 0 & 0 \\
\hline Mo & 0.85 & 1.7 & 0 & 0 & 0 \\
\hline $\mathrm{Na}$ & 3.4 & 9350 & 66300 & 102000 & 22950 \\
\hline $\mathrm{Nd}$ & 1.7 & 0 & 0 & 0 & 0 \\
\hline $\mathrm{Ni}$ & 1.7 & 0 & 6.8 & 0 & 2.55 \\
\hline$P$ & 4.3 & 740 & 570 & 306 & 4930 \\
\hline $\mathrm{Pb}$ & 2.6 & 0 & 0 & 0 & 0 \\
\hline Pd & 6.8 & 0 & 0 & 0 & 0 \\
\hline $\mathbf{R h}$ & 4.3 & 0 & 0 & 0 & 0 \\
\hline Ru & 4.3 & 0 & 0 & 0 & 0 \\
\hline $\mathrm{Sb}$ & 2.6 & 0 & 0 & 0 & 0 \\
\hline $\mathrm{Se}$ & 3.4 & 0 & 0 & 0 & 0 \\
\hline $\mathrm{si}$ & 2.6 & 0 & 29.8 & 119 & 8.5 \\
\hline Sn & 43 & 0 & 0 & 0 & 0 \\
\hline $\mathrm{Sr}$ & 0.26 & 0 & 0 & 0 & 0 \\
\hline $\mathrm{Te}$ & 8.5 & 0 & 0 & 0 & 0 \\
\hline $\mathrm{Th}$ & 34 & 0 & 0 & 0 & 0 \\
\hline $\mathrm{Ti}$ & 0.26 & 0 & 0 & 0 & 0 \\
\hline $\mathrm{Tl}$ & 26 & 0 & 0 & 0 & 0 \\
\hline $\mathrm{U}$ & 0.00003 & 53.7 & 39.7 & .37 .4 & 4.45 \\
\hline $\mathbf{v}$ & 0.43 & 0 & 0 & 0 & 0 \\
\hline w & 3.4 & 0 & 0 & 0 & 0 \\
\hline$Y$ & 0.43 & 0 & 0 & 0 & 0 \\
\hline$Z_{n}$ & 0.85 & 0 & 23 & 15.3 & 3.4 \\
\hline $\mathrm{Zr}$ & 0.43 & 0 & 0 & 0.85 & 0 \\
\hline $\mathrm{NO}_{3}^{-}$ & 500 & 13900 & 4300 & 1810 & 150 \\
\hline $\mathrm{NO}_{2}^{-}$ & 50 & 2530 & 790 & 290 & 420 \\
\hline $\mathrm{PO}_{4}^{3-}$ & 50 & 2310 & 1920 & 790 & 14600 \\
\hline $\mathrm{SO}_{4}{ }^{2-}$ & 50 & 1440 & 500 & 70 & 20 \\
\hline$F^{-}$ & 25 & 550 & 5200 & 0 & 2200 \\
\hline $\mathrm{Cl}^{-}$ & 25 & 140 & 50 & 20 & 0 \\
\hline $\mathrm{Br}$ & 25 & 0 & 0 & 0 & 0 \\
\hline
\end{tabular}

(a) Zero values indicate the analyte was below the detection limit.

\section{B.3}


Table B.2. Concentrations of the Nonradioactive Sludge Components in the Leached Sludge From the BX-107 Test

\begin{tabular}{|c|c|c|}
\hline Component & Detection Limit, $\mu \mathrm{g} / \mathrm{g}$ & Concentration, $\mu \mathrm{g} / \mathrm{g}(a$ \\
\hline $\mathrm{Ag}$ & 20 & 0 \\
\hline$A 1$ & 100 & 41000 \\
\hline As & 100 & 0 \\
\hline B & 40 & 4100 \\
\hline $\mathbf{B} \mathbf{a}$ & 20 & 60 \\
\hline $\mathrm{Be}$ & 9 & 0 \\
\hline $\mathbf{B i}$ & 200 & 350000 \\
\hline $\mathrm{Ca}$ & 90 & 1500 \\
\hline $\mathrm{Cd}$ & 20 & 30 \\
\hline $\mathrm{Ce}$ & 100 & 900 \\
\hline $\mathrm{Co}$ & 20 & 30 \\
\hline $\mathrm{Cr}$ & 40 & 4400 \\
\hline $\mathrm{Cu}$ & 20 & 100 \\
\hline Dy & 40 & 0 \\
\hline Eu & 20 & 0 \\
\hline $\mathrm{Fe}$ & 20 & 72000 \\
\hline G d & 400 & 0 \\
\hline $\mathbf{K}$ & (b) & (b) \\
\hline La & 50 & 0 \\
\hline $\mathrm{Li}$ & 40 & 0 \\
\hline $\mathbf{M g}_{\mathbf{g}}$ & 100 & 900 \\
\hline $\mathrm{Mn}$ & 9 & 360 \\
\hline Mo & 40 & so \\
\hline $\mathbf{N a}$ & 100 & 84000 \\
\hline $\mathrm{Nd}$ & 50 & 0 \\
\hline $\mathrm{Ni}$ & (c) & (c) \\
\hline $\mathbf{P}$ & 200 & 17000 \\
\hline $\mathrm{Pb}$ & 100 & 600 \\
\hline $\mathrm{Pd}$ & 300 & 0 \\
\hline $\mathbf{R ~ h}$ & 200 & 0 \\
\hline Ru & 200 & 0 \\
\hline $\mathbf{S b}$ & 90 & 0 \\
\hline $\mathrm{Se}$ & 100 & 200 \\
\hline$S i$ & 90 & 49000 \\
\hline Sn & 2000 & 0 \\
\hline $\mathrm{Sr}$ & 9 & 940 \\
\hline $\mathrm{Te}$ & 400 & 0 \\
\hline$T h$ & 1000 & 0 \\
\hline $\mathrm{Ti}$ & 9 & 70 \\
\hline $\mathbf{T l}$ & 900 & 0 \\
\hline $\mathbf{U}$ & 0.00003 & 16900 \\
\hline $\mathrm{V}$ & 20 & 0 \\
\hline $\mathbf{w}$ & 100 & 0 \\
\hline $\mathbf{Y}$ & 20 & 0 \\
\hline $\mathrm{Zn}$ & 40 & 300 \\
\hline$Z_{r}$ & 20 & 860 \\
\hline $\mathrm{NO}_{3}$ & (d) & (d) \\
\hline $\mathrm{NO}_{2}^{-}$ & (d) & (d) \\
\hline $\mathrm{PO}_{4}^{3-}$ & 17900 & 20000 \\
\hline $\mathrm{SO}_{4}^{2}$ & $7175^{\circ}$ & 4835 \\
\hline $\mathbf{F}^{-}$ & 17900 & 0 \\
\hline $\mathrm{Cl}^{-}$ & (d) & (d) \\
\hline $\mathrm{Br}^{-}$ & 17900 & 0 \\
\hline \multicolumn{3}{|c|}{ (a) Zero values indicate the analyte was below the detection limit. } \\
\hline \multicolumn{3}{|c|}{$\begin{array}{l}\text { (b) Potassium values are not reported since the sample was } \\
\text { dissolved using a KOH fusion method. }\end{array}$} \\
\hline \multicolumn{3}{|c|}{$\begin{array}{l}\text { (c) Nickel values are not reported because a Ni crucible was } \\
\text { used during the KOH fusion method. } \\
\text { (d) Measurement impractical due to method of sample preparation. }\end{array}$} \\
\hline
\end{tabular}


Table B.3. Distribution of the Nonradioactive Sludge Components Between the Various Process Streams From the BX-107 Test

\begin{tabular}{|c|c|c|c|c|c|}
\hline \multirow[b]{2}{*}{ Component } & \multicolumn{5}{|c|}{ Amount of Component Found, $\%$} \\
\hline & $\begin{array}{l}\text { Retrieval } \\
\text { Solution (E) }\end{array}$ & $\begin{array}{l}\text { First Caustic } \\
\text { Leach }(G)\end{array}$ & $\begin{array}{l}\text { Second Caustic } \\
\text { Leach (1) }\end{array}$ & Wash $(K)$ & Resiodue (A) \\
\hline $\mathrm{Ag}$ & (a) & (a) & (a) & (a) & (a) \\
\hline $\mathrm{Al}$ & 1 & 49 & 11 & 7 & 32 \\
\hline As & 0 & 82 & 18 & 0 & 0 \\
\hline B & 5 & 1 & 0. & 0 & 94 \\
\hline $\mathbf{B a}$ & 0 & 0 & 0 & 0 & 100 \\
\hline$\dot{\mathrm{Be}}$ & (a) & (a) & (a) & (a) & (a) \\
\hline $\mathrm{Bi}$ & 0 & 0 & 0 & 0 & 100 \\
\hline $\mathbf{C a}$ & 14 & 4 & 0 & 10 & 73 \\
\hline $\mathrm{Cd}$ & 0 & 0 & 0 & 0 & 100 \\
\hline $\mathrm{Ce}$ & 0 & 0 & 0 & 0 & 100 \\
\hline $\mathrm{Co}$ & 0 & 0 & 0 & 0 & 100 \\
\hline $\mathrm{Cr}$ & 21 & 3 & 3 & 2 & 71 \\
\hline $\mathrm{Cu}$ & 0 & $\mathbf{0}$ & 4 & 0 & 96 \\
\hline Dy & (a) & (a) & (a) & (a) & (a) \\
\hline Eu & (a) & (a) & (a) & (a) & (a) \\
\hline $\mathrm{Fe}$ & 0 & 0 & 0 & 0 & 100 \\
\hline Gd & (a) & (a) & (a) & (a) & (a) \\
\hline K & (b) & (b) & (b) & (b) & (b) \\
\hline La & (a) & (a) & (a) & (a) & (a) \\
\hline $\mathrm{Li}$ & (a) & (a) & (a) & (a) & (a) \\
\hline $\mathbf{M ~ g ~}_{\mathbf{g}}$ & 0 & 0 & 0 & 0 & 100 \\
\hline $\mathbf{M n}$ & 10 & 1 & 0 & 0 & 89 \\
\hline Mo & 69 & 0 & 0 & 0 & 31 \\
\hline $\mathrm{Na}$ & (c) & (c) & (c) & (c) & (c) \\
\hline Nd & (a) & (a) & (a) & (a) & (a) \\
\hline $\mathrm{Ni}$ & (b) & (b) & (b) & (b) & (b) \\
\hline $\mathbf{P}$ & 20 & 2 & 1 & 70 & 7 \\
\hline $\mathbf{P b}$ & 0 & 0 & 0 & 0 & 100 \\
\hline $\mathbf{P d}$ & (a) & (a) & (a) & (a) & (a) \\
\hline $\mathbf{R h}$ & (a) & (a) & (a) & (a) & (a) \\
\hline $\mathrm{Ru}$ & (a) & (a) & (a) & (a) & (a) \\
\hline $\mathrm{Sb}$ & (a) & (a) & (a) & (a) & (a) \\
\hline $\mathrm{Se}$ & 0 & 0 & 0 & 0 & 100 \\
\hline $\mathrm{Si}$ & 0 & 1 & 1 & 1 & 98 \\
\hline Sn & (a) & (a) & (a) & (a) & (a) \\
\hline $\mathrm{Sr}$ & 0 & 0 & 0 & 0 & 100 \\
\hline $\mathrm{Te}$ & (a) & (a) & (a) & (a) & (a) \\
\hline$T h$ & (a) & (a) & (a) & (a) & (a) \\
\hline $\mathbf{T i}$ & 0 & 0 & 0 & 0 & 100 \\
\hline $\mathrm{Tl}$ & (a) & (a) & (a) & (a) & (a) \\
\hline $\mathrm{U}$ & 16 & 2 & 1 & 1 & 80 \\
\hline $\mathrm{v}$ & (a) & (a) & (a) & (a) & (a) \\
\hline$w$ & (a) & (a) & (a) & (a) & (a) \\
\hline $\mathbf{Y}$ & (a) & (a) & (a) & (a) & (a) \\
\hline $\mathbf{Z}_{\mathbf{n}}$ & 0 & 29 & 12 & 16 & 43 \\
\hline $\mathrm{Z}_{\mathbf{r}}$ & 0 & 0 & 1 & 0 & 99 \\
\hline $\mathrm{NO}_{3}$ & 95 & 4 & 1 & 1 & (d) \\
\hline $\mathrm{NO}_{2}^{-}$ & 88 & 4 & 1 & 7 & (d) \\
\hline $\mathrm{PO}_{4}{ }^{3-}$ & 22 & 2 & 1 & 72 & 3 \\
\hline $\mathrm{SO}_{4}^{2-}$ & 90 & 4 & 0 & 1 & 5 \\
\hline$F^{-}$ & $23(21)^{(\theta)}$ & $29(26)^{(4)}$ & 0 & $47(42)^{(\theta)}$ & $0(10)^{(e)}$ \\
\hline $\mathrm{Cr}$ & 94 & 5 & 1 & 0 & (d) \\
\hline $\mathrm{Br}^{-}$ & (a) & (a) & (a) & (a) & (a) \\
\hline \multicolumn{6}{|c|}{ (a) Component was not detected. } \\
\hline \multicolumn{6}{|c|}{$\begin{array}{l}\text { (b) } \mathrm{K} \text { and } \mathrm{Ni} \text { values could not be determined due to the } \mathrm{KOH} \text { fusion procedure used } \\
\text { to prepare the leached sludge for analysis. }\end{array}$} \\
\hline \multicolumn{6}{|c|}{$\begin{array}{l}\text { (c) Removal of Na from the sludge cannot be reliably tracked because the } \mathrm{Na} \text { in the sludge } \\
\text { cannot be distinguished from the } \mathrm{Na} \text { added in the washing and leaching. } \\
\text { (d) Measurement impractical due to method of sample preparation. } \\
\text { (e) Values in parenthases represent the values obtained if, for cases where the component } \\
\text { was below the detection limit, the component concentration was assumed to be the det }\end{array}$} \\
\hline
\end{tabular}

\section{B.5}


Table B.4. Mass Balance for Nonradioactive Sludge Components From the BX-107 Test

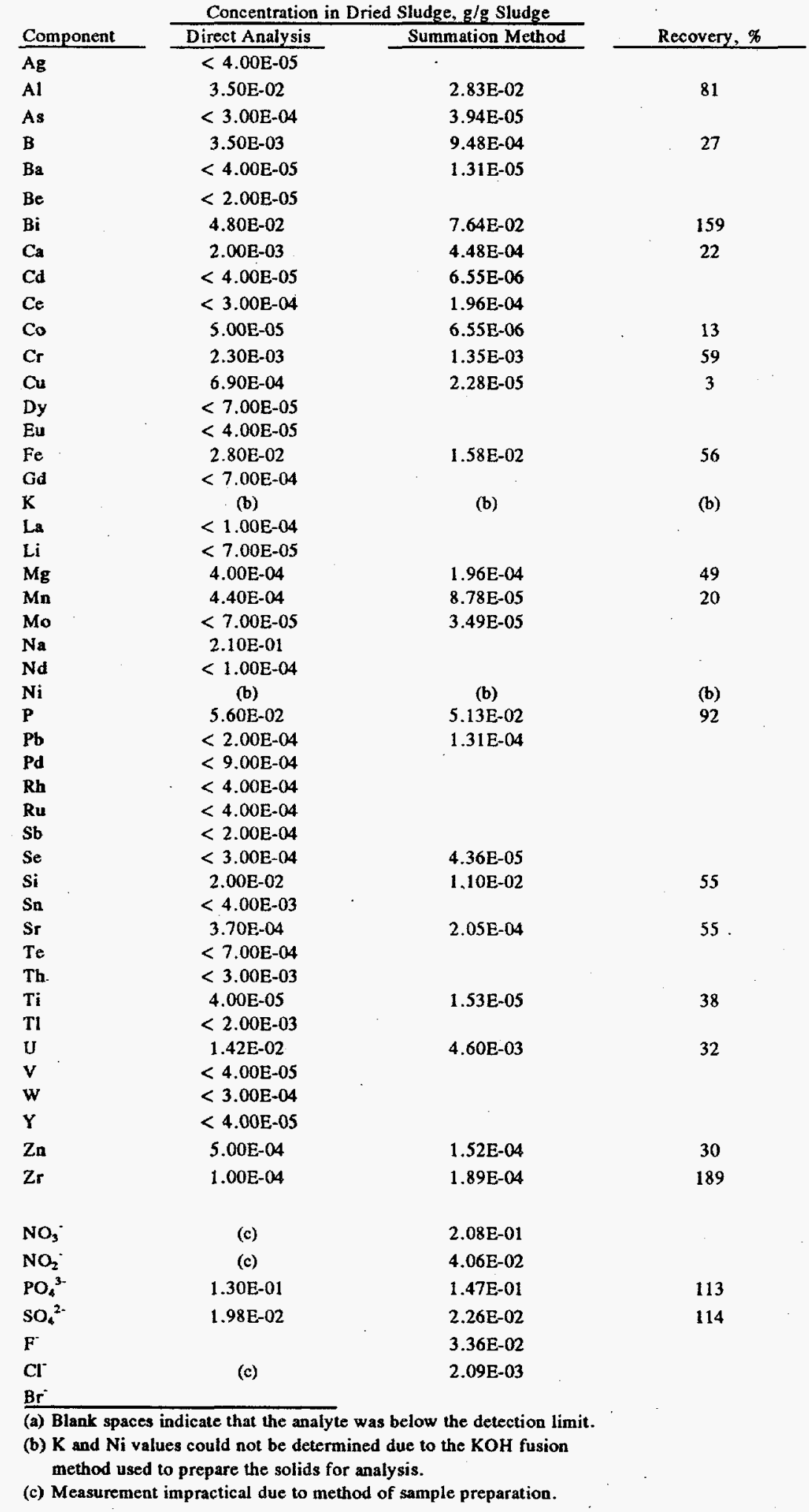

B.6 
Table B.5. Concentrations of the Radioactive Sludge Components in the Various Process Streams From the BX-107 Test

Concentration, $\mu \mathrm{Ci} / \mathrm{mL}$

$\frac{\text { Component }}{\text { Total Alpha }}$
${ }^{239,240} \mathrm{Pu}$
${ }^{241} \mathrm{Am}+{ }^{238} \mathrm{Pu}$
${ }^{241} \mathrm{Am}(\gamma)$
${ }^{137} \mathrm{Cs}$
${ }^{90} \mathrm{Sr}$
${ }^{90}$

\begin{tabular}{|c|c|c|c|}
\hline $\begin{array}{c}\text { Retrieval } \\
\text { Solution (E) }\end{array}$ & $\begin{array}{c}\text { First Caustic } \\
\text { Leach (G) }\end{array}$ & $\begin{array}{l}\text { Second Caustic } \\
\text { Leach (I) }\end{array}$ & Wash $(\mathrm{K})$ \\
\hline$<2.55 \mathrm{E}-05$ & $2.38 \mathrm{E}-05$ & $1.00 \mathrm{E}-04$ & $<2.55 \mathrm{E}-05$ \\
\hline $\mathrm{ND}^{(\mathrm{a})}$ & ND & ND & ND \\
\hline ND & ND & ND & ND \\
\hline$<5.00 \mathrm{E}-05$ & $<3.00 \mathrm{E}-04$ & $<2.00 \mathrm{E}-04$ & $<5.00 \mathrm{E}-05$ \\
\hline $4.02 \mathrm{E}-01$ & $9.01 \mathrm{E}+\infty 0$ & $4.00 \mathrm{E}+00$ & $4.38 E-01$ \\
\hline 7.49E-04 & $1.30 \mathrm{E}-03$ & $3.94 \mathrm{E}-03$ & $2.11 \mathrm{E}-03$ \\
\hline $4.73 \mathrm{E}-03$ & $1.88 \mathrm{E}-03$ & $6.95 \mathrm{E}-04$ & $5.29 \mathrm{E}-05$ \\
\hline
\end{tabular}

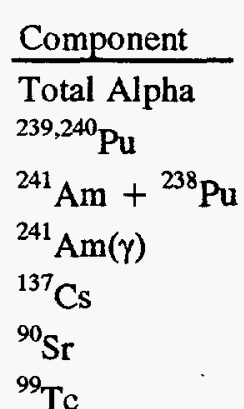

Concentration, $\mu \mathrm{Ci} / \mathrm{g}$

4.18E-03

(a) ND = Not Determined. The low total alpha activity made these separations impractical. 
Table B.6. Distribution of the Radioactive Sludge Components Between the Various Process Streams From the BX-107 Test

\begin{tabular}{|c|c|c|c|c|c|}
\hline \multirow[b]{2}{*}{ Component } & \multicolumn{5}{|c|}{ Amount of Component Found, \% } \\
\hline & $\begin{array}{c}\text { Retrieval } \\
\text { Solution (E) }\end{array}$ & $\begin{array}{l}\text { First Caustic } \\
\text { Leach (G) }\end{array}$ & $\begin{array}{l}\text { Second Caustic } \\
\text { Leach (I) }\end{array}$ & Wash (K) & Residue (A) \\
\hline Total Alpha & 0 & 0 & 0 & 0 & 100 \\
\hline${ }^{239,240} \mathrm{Pu}$ & (a) & (a) & (a) & (a) & 100 \\
\hline${ }^{241} \mathrm{Am}+{ }^{238} \mathrm{Pu}$ & (a) & (a) & (a) & (a) & 100 \\
\hline${ }^{241} \operatorname{Am}(\gamma)$ & 0 & 0 & 0 & 0 & 100 \\
\hline${ }^{137} \mathrm{Cs}$ & 17 & 52 & 15 & 10 & 6 \\
\hline${ }^{90} \mathrm{Sr}$ & 0 & 0 & 0 & 0 & 100 \\
\hline${ }^{99} \mathrm{Tc}$ & 92 & 5 & 1 & 1 & 1 \\
\hline
\end{tabular}

(a) Not determined due to a lack of alpha activity in some components.

Table B.7. Mass Balance for Radioactive Sludge Components From the BX-107 Test

Concentration in Dried Sludge, $\mu \mathrm{Ci} / \mathrm{g}$

\begin{tabular}{|c|c|c|c|}
\hline Component & Direct Analysis & Summation Method & Recovery, \% \\
\hline Total Alpha & $3.45 \mathrm{E}-01$ & $3.08 \mathrm{E}-01$ & 89 \\
\hline${ }^{239,240} \mathrm{Pu}$ & $3.08 \mathrm{E}-01$ & $2.75 \mathrm{E}-01$ & 89 \\
\hline${ }^{241} \mathrm{Am}+{ }^{238} \mathrm{Pu}$ & $3.24 \mathrm{E}-02$ & $3.16 \mathrm{E}-02$ & 98 \\
\hline${ }^{241} \operatorname{Am}(\gamma)$ & $<2.08 \mathrm{E}-01$ & 2.73E-02 & \\
\hline${ }^{137} \mathrm{Cs}$ & $3.81 E+01$ & $3.27 \mathrm{E}+01$ & 86 \\
\hline${ }^{90} \mathrm{Sr}$ & $2.30 \mathrm{E}+01$ & $1.66 \mathrm{E}+01$ & 72 \\
\hline${ }^{99} \mathrm{Tc}$ & $5.16 \mathrm{E}-02$ & $7.25 \mathrm{E}-02$ & 140 \\
\hline
\end{tabular}

B. 8 

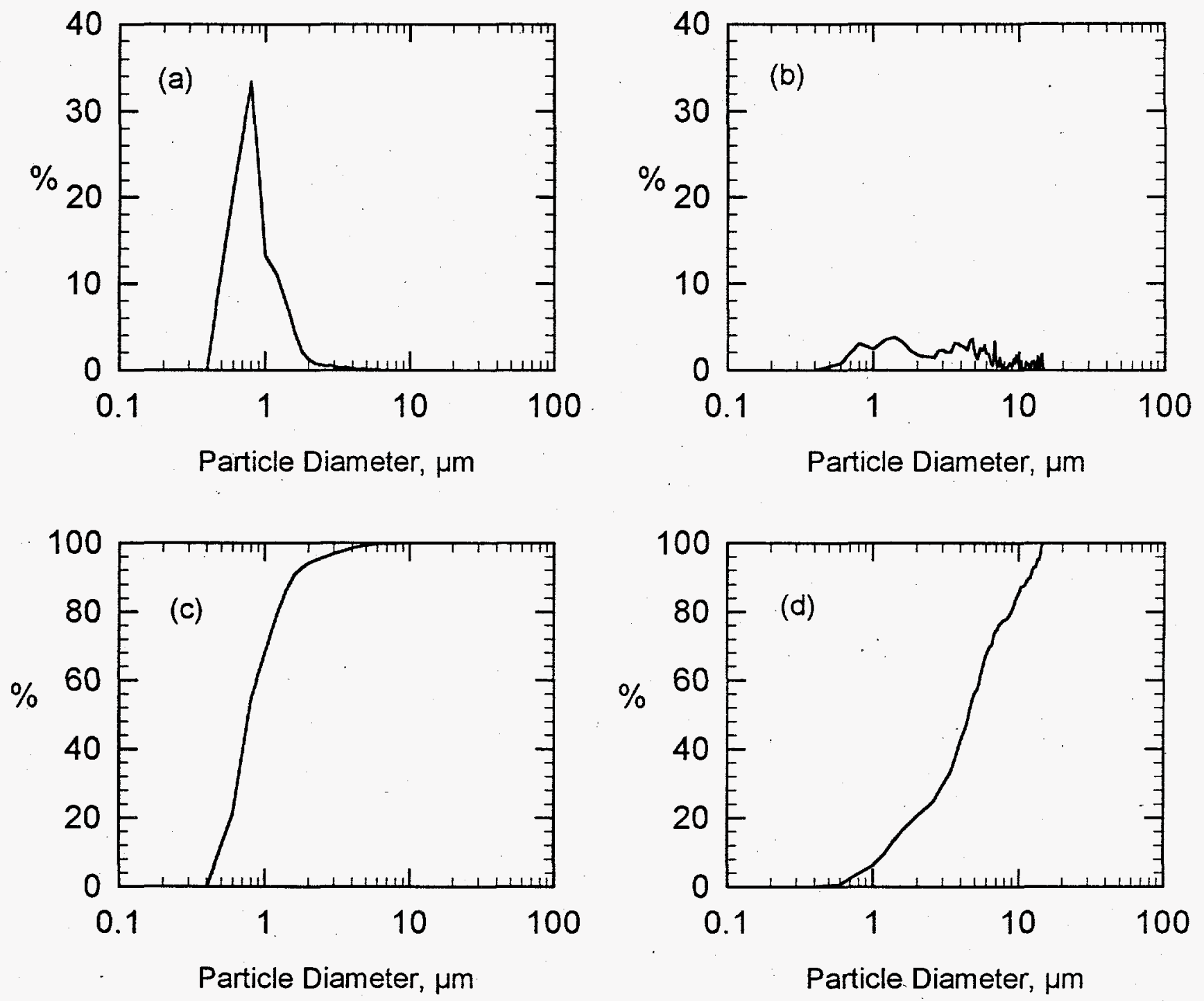

BX107-2C.SPW

Figure B.1. Particle-Size Data for Untreated BX-107 Sludge: a) Probability-Number Density Graph, b) Probability Volume-Density Graph, c) Probability-Number Distribution Graph, and d) Probability-Volume Distribution Graph. 

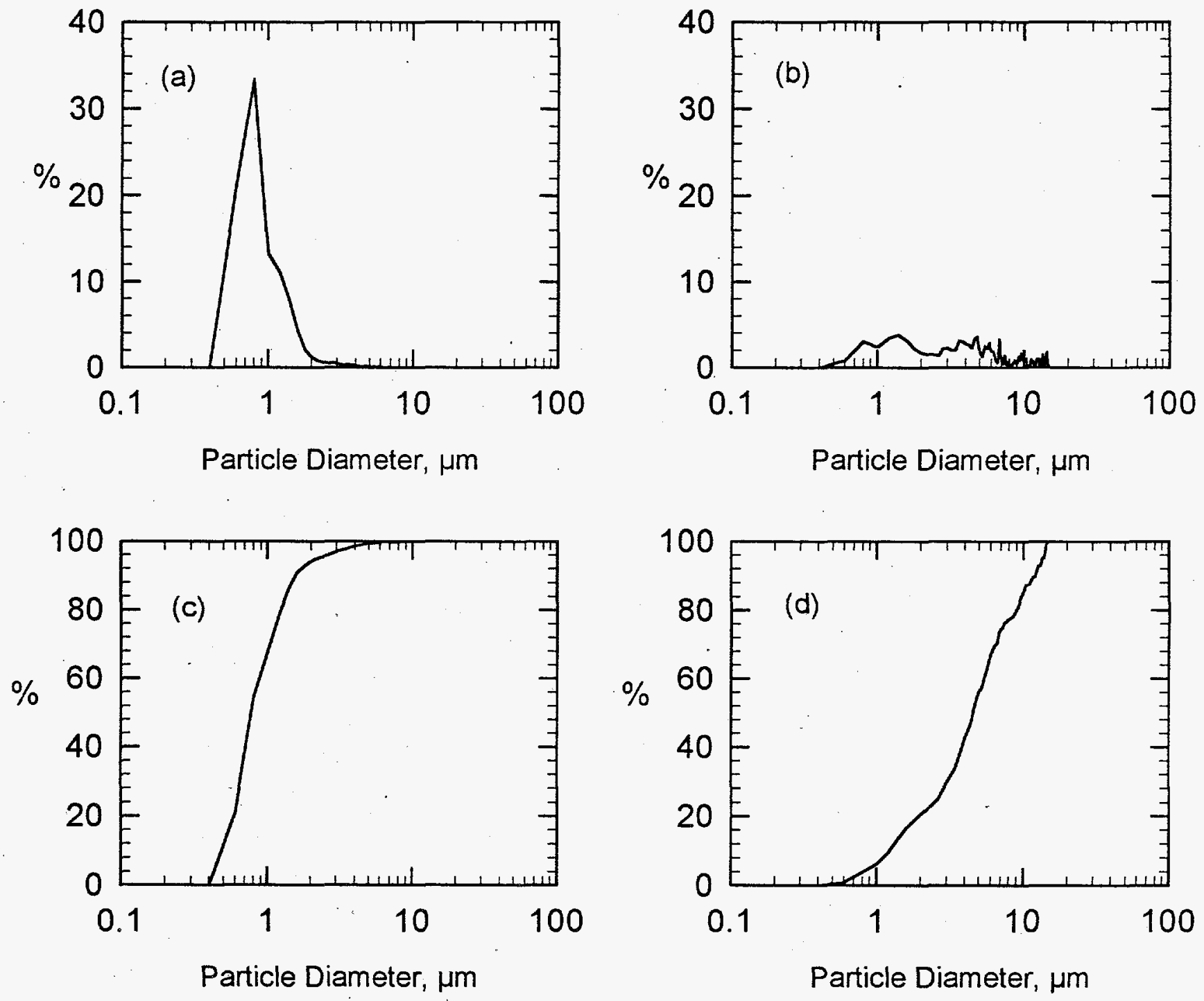

BX107-2C.SPW

Figure B.2. Particle-Size Data for Untreated BX-107 Sludge: a) Probability-Number Density Graph, b) Probability Volume-Density Graph, c) Probability-Number Distribution Graph, and d) Probability-Volume Distribution Graph. 

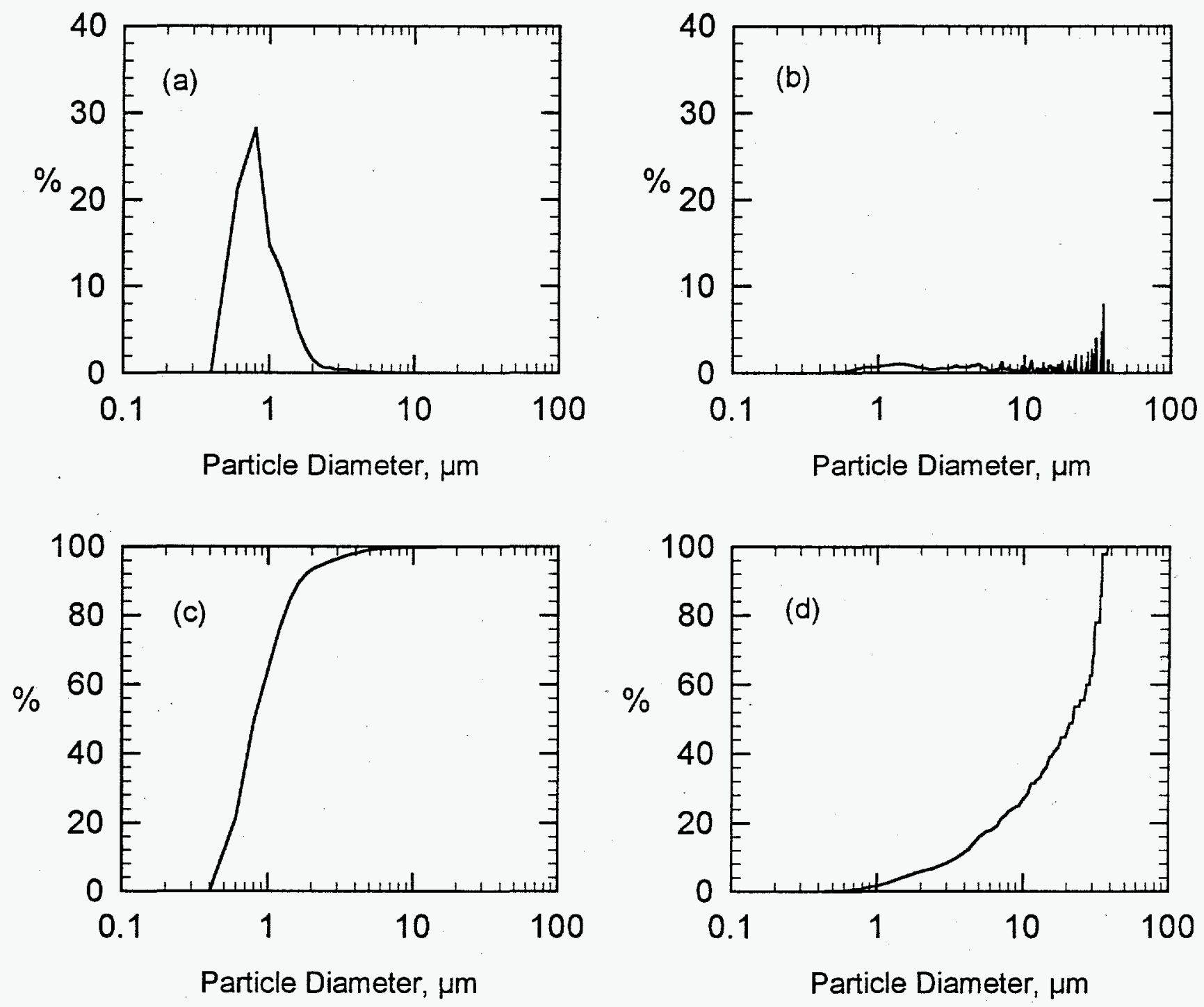

BX107-2M.SPW

Figure B.3. Particle-Size Data for Treated BX-107 Sludge: a) Probability-Number Density Graph, b) Probability-Volume Density Graph, c) Probability-Number Distribution Graph, and d) Probability-Volume Distribution Graph. 


\section{Appendix C}

Results from the Tank C-103 Sludge Washing and Caustic Leaching Test 


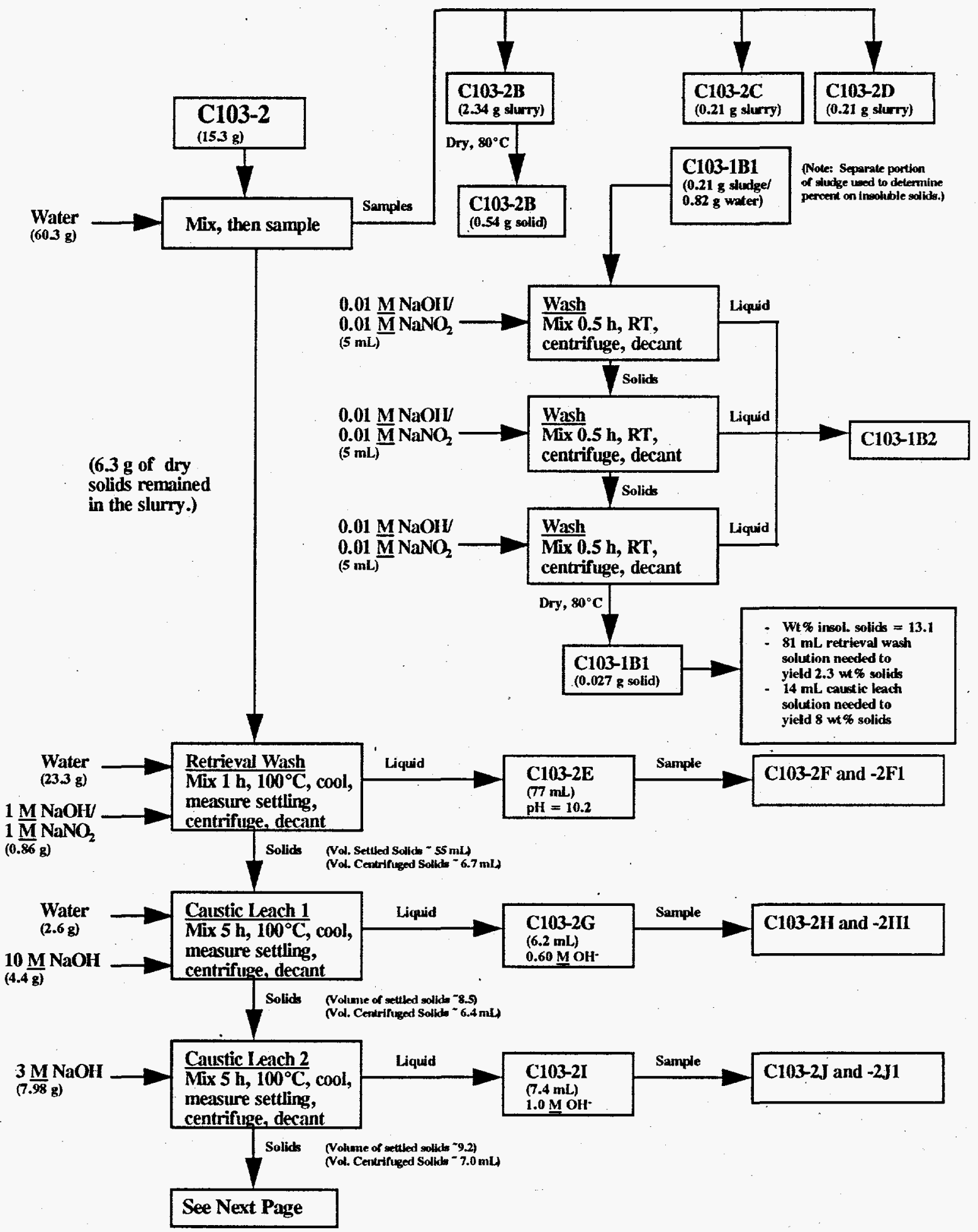

Figure C.1. Schematic of C-103 Sludge Washing and Caustic Leaching Test

C. 1 


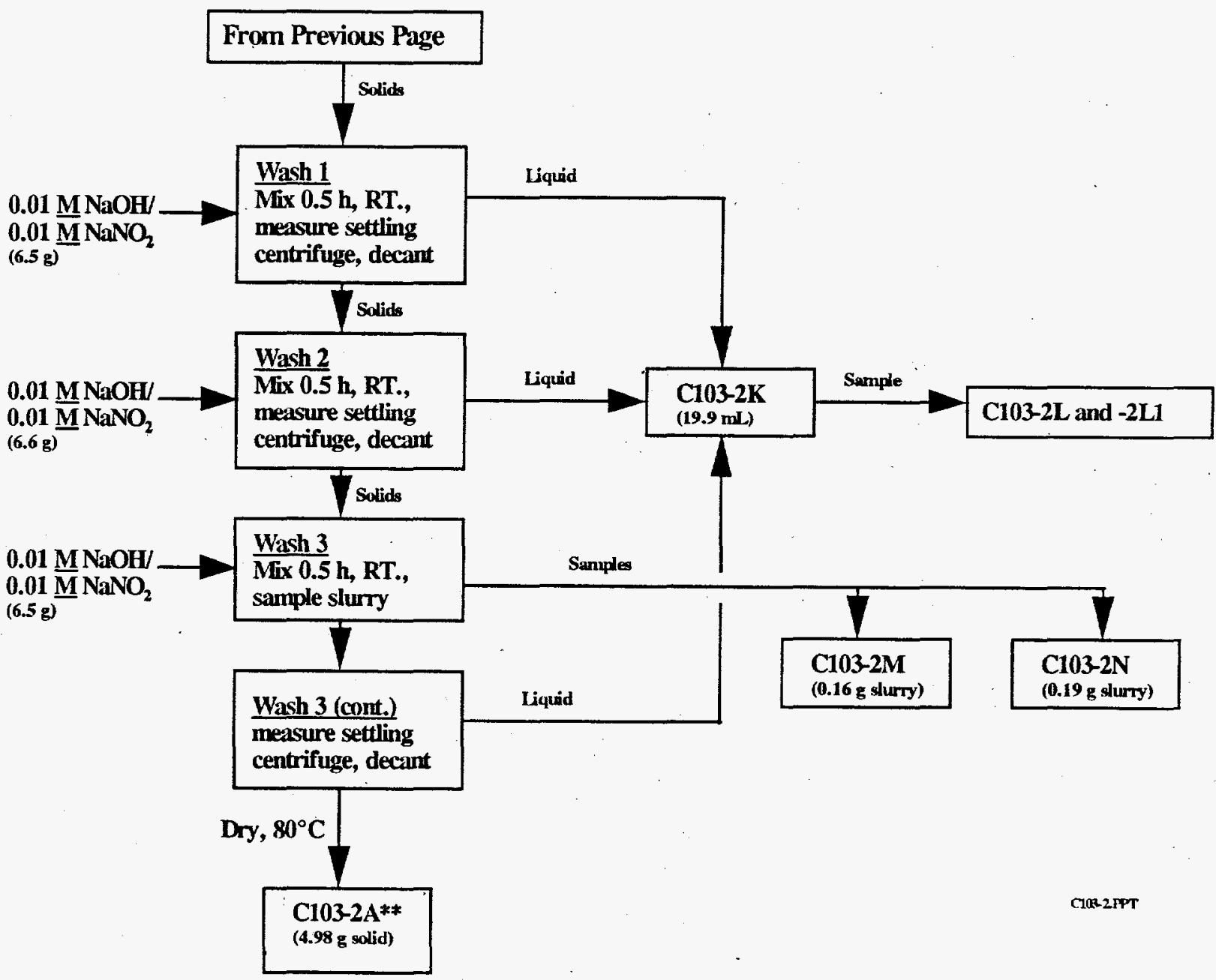

Figure C.1. (contd.) 
Table C.1. Concentrations of the Nonradioactive Sludge Components in the Various Process Solutions From the C-103 Test

\begin{tabular}{|c|c|c|c|c|c|}
\hline \multirow[b]{2}{*}{ Component } & \multirow[b]{2}{*}{$\begin{array}{c}\text { Detection Limit. } \\
\mu \mathrm{g} / \mathrm{mL}^{(\omega)} \\
\end{array}$} & \multicolumn{4}{|c|}{ Concentration, $\mu \mathrm{g} / \mathrm{mL}^{(b)}$} \\
\hline & & $\begin{array}{l}\text { Retrieval Solution } \\
\text { (E) }\end{array}$ & $\begin{array}{c}\text { First Caustic } \\
\text { Lench }(G)\end{array}$ & $\begin{array}{c}\text { Second Caustic } \\
\text { Leach (I) }\end{array}$ & Wash (K) \\
\hline $\mathrm{Ag}$ & 0.085 & 0.17 & 0 & 0 & 0 \\
\hline Al & 0.51 & 7.23 & 25500 & 30600 & 4505 \\
\hline As & 0.68 & $\mathbf{0}$ & 22.95 & 27.2 & 5.1 \\
\hline B & 0.17 & $\mathbf{0}$ & 0.85 & 0.6 & 0 \\
\hline $\mathrm{Ba}$ & 0.085 & 0.68 & 0 & 0 & 0 \\
\hline $\mathrm{Be}$ & 0.043 & 0 & 0.17 & 0.17 & 0 \\
\hline $\mathrm{Bi}$ & 0.85 & 0 & 2.55 & 2.55 & 0 \\
\hline $\mathrm{Ca}$ & 0.43 & 3.4 & 5.95 & 5.1 & 9.35 \\
\hline Cd & 0.085 & 0.34 & 0 & 0 & 0 \\
\hline $\mathrm{Ce}$ & 0.68 & 0 & 0 & 0 & 0 \\
\hline Co & 0.085 & 0 & 0.51 & 0.51 & 0 \\
\hline $\mathrm{Cr}$ & 0.17 & 1.7 & 44.2 & 34.85 & 6.38 \\
\hline $\mathrm{Cu}$ & 0.085 & 24.65 & 170 & 102 & 10.2 \\
\hline Dy & 0.17 & 0 & 0 & 0 & 0 \\
\hline $\mathrm{Eu}$ & 0.085 & 0 & 0 & 0 & 0 \\
\hline $\mathrm{Fe}$ & 0.085 & 12.75 & 2.38 & 2.55 & 0.43 \\
\hline Gd & 1.7 & 0 & 0 & 0 & 0 \\
\hline $\mathbf{K}$ & 17 & 25.5 & 170 & 85 & 25.5 \\
\hline $\mathbf{L a}$ & 0.26 & 0 & 0 & 0 & 0 \\
\hline $\mathbf{L i}$ & 0.17 & 0.85 & 0 & 0 & 0 \\
\hline $\mathbf{M g}$ & 0.68 & 1.7 & 0 & 0 & 0.85 \\
\hline Mn & 0.043 & 0.94 & 0 & 0 & 0 \\
\hline Mo & 0.17 & 0.85 & 0.85 & 0.43 & 0 \\
\hline $\mathrm{Na}$ & 0.68 & 3995 & 69700 & 69700 & 11900 \\
\hline $\mathbf{N d}$ & 0.26 & 0 & 0 & 0 & 0 \\
\hline $\mathrm{Ni}$ & 0.26 & 3.4 & 1.7 & 1.7 & 3.32 \\
\hline $\mathbf{P}$ & 0.85 & 153 & 1530 & 697 & 145 \\
\hline $\mathrm{Pb}$ & 0.51 & 1.7 & 0 & 0 & 0 \\
\hline Pd & 1.7 & 0 & 0 & 0 & 0 \\
\hline Rh & 0.85 & 0 & 0 & 0 & 0 \\
\hline Ru & 0.85 & 0 & 0 & 0 & 0 \\
\hline Sb & 0.43 & 0 & 0 & 0 & 0 \\
\hline $\mathrm{Se}$ & 0.68 & 0 & 2.55 & 3.4 & 0 \\
\hline $\mathrm{Si}$ & 0.43 & 4.93 & 55.25 & 47.6 & 1.7 \\
\hline Sn & 8.5 & 0 & 42.5 & 25.5 & 0 \\
\hline $\mathrm{Sr}$ & 0.043 & 0 & 0 & 0 & 0 \\
\hline $\mathrm{Te}$ & 1.7 & 0 & 0 & 0 & 0 \\
\hline Th & 6.8 & 0 & 0 & 0 & 0 \\
\hline$T_{i}$ & 0.043 & 0.05 & 0 & 0 & 0 \\
\hline $\mathrm{Tl}$ & 0.43 & 0 & 42.5 & 51 & 8.5 \\
\hline $\mathrm{U}$ & 0.00425 & 334 & 78.4 & 64.3 & 8.6 \\
\hline$V$ & 0.085 & 0 & 2.04 & 0.8 & 0.26 \\
\hline$w$ & 0.68 & 1.7 & 15.3 & 8.5 & 2.6 \\
\hline$Y$ & 0.085 & 0 & 0 & 0 & 0 \\
\hline $\mathrm{Zn}$ & 0.17 & 0.6 & 31.45 & 23.8 & 3.91 \\
\hline $\mathrm{Zr}$ & 0.085 & 19.55 & 2.55 & 2.38 & 0 \\
\hline $\mathrm{NO}_{3}^{-}$ & 0.5 & 60 & $<50$ & $<50$ & $<50$ \\
\hline $\mathrm{NO}_{2}^{-}$ & 0.5 & 1100 & 440 & 160 & 330 \\
\hline $\mathrm{PO}_{4}^{3-}$ & 0.5 & 290 & 2770 & 840 & $270^{\circ}$ \\
\hline $\mathrm{SO}_{4}^{2-}$ & 0.5 & 220 & $<50$ & $<50$ & $<50$ \\
\hline$F$ & 0.25 & (c) & (c) & (c) & (c) \\
\hline $\mathrm{Cl}^{-}$ & 0.25 & 30 & (c) & (c) & (c) \\
\hline $\mathrm{Br}$ & 25 & 0 & 0 & 0 & 0 \\
\hline
\end{tabular}

(a) The detection limits for two caustic leach solutions ( $G$ and $I$ ) solutions are twice the values reported in this column.

(b) Zero values indicate the analyte was below the detection limit.

(c) Analyte coukd not be accurately determined due to matrix effects. 
Table C.2. Concentrations of the Nonradioactive Sludge Components in the Leached Sludge From the C-103 Test

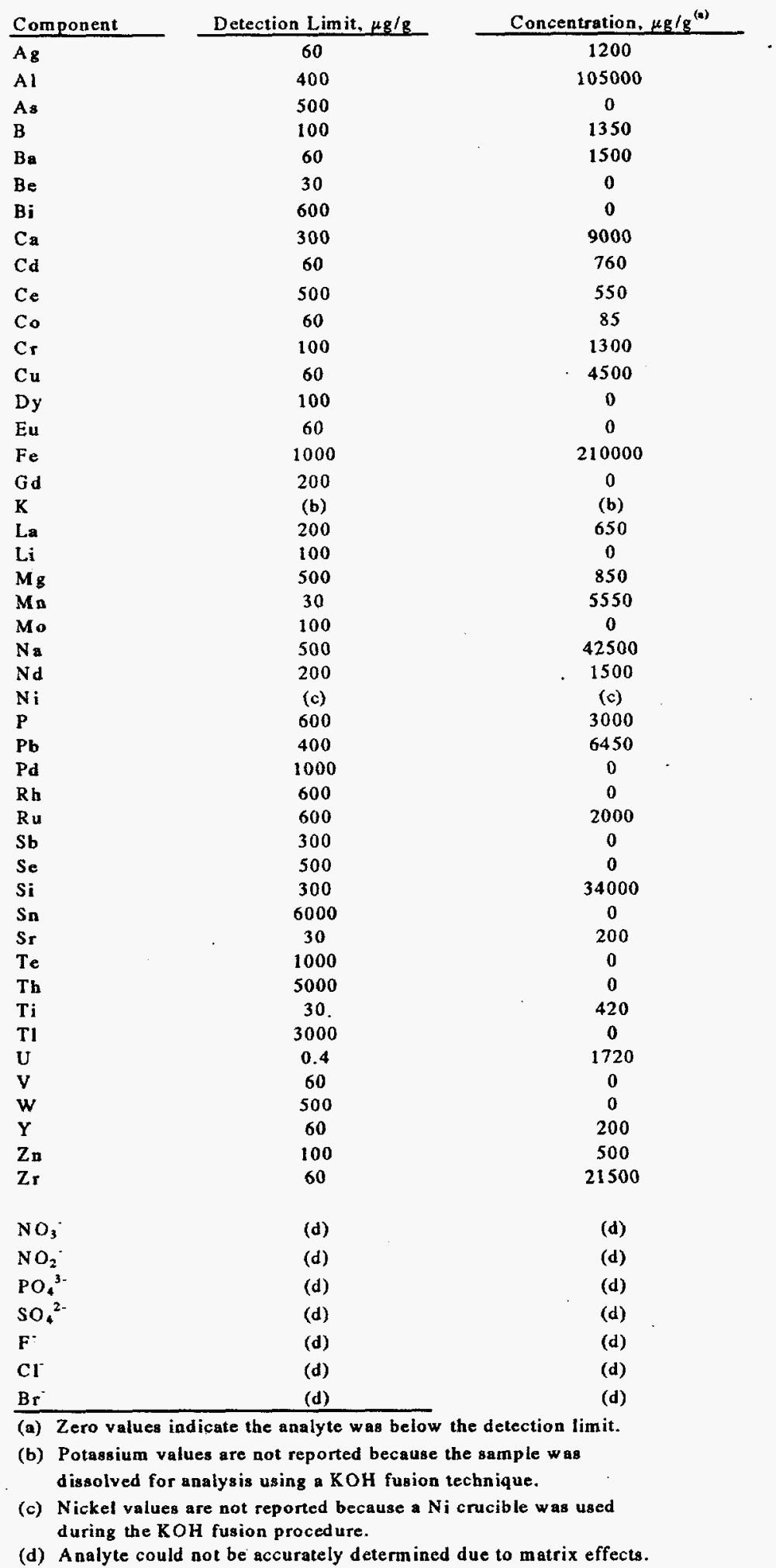

C. 4 
Table C.3. Distribution of the Nonradioactive Sludge Components Between the Various Process Streams From the C-103 Test

\begin{tabular}{|c|c|c|c|c|c|}
\hline \multirow[b]{2}{*}{ Component } & \multicolumn{5}{|c|}{ Amount of Component Found, $\%$} \\
\hline & $\begin{array}{c}\text { Retrieval } \\
\text { Solution (E) } \\
\end{array}$ & $\begin{array}{c}\text { First Caustic } \\
\text { Leach (G) }\end{array}$ & $\begin{array}{c}\text { Second Caustic } \\
\text { Leach (D) }\end{array}$ & Wash $(\mathrm{K})$ & Residue (A) \\
\hline $\mathrm{Ag}$ & 0 & 0 & 0 & 0 & 100 \\
\hline Al & 0 & 16 & 23 & 9 & 52 \\
\hline As & 0 & 32 & 45 & 23 & 0 \\
\hline B & 0 & 0 & 0 & 0 & 100 \\
\hline $\mathbf{B a}$ & 1 & 0 & 0 & 0 & 99 \\
\hline $\mathrm{Be}$ & 0 & 46 & 54 & 0 & 0 \\
\hline $\mathrm{Bi}$ & 0 & 46 & 54 & 0 & 0 \\
\hline $\mathrm{Ca}$ & 1 & 0 & 0 & 0 & 99 \\
\hline $\mathrm{Cd}$ & 1 & 0 & 0 & 0 & 99 \\
\hline $\mathrm{Ce}$ & 0 & 0 & 0 & 0 & 100 \\
\hline Co & 0 & 1 & 1 & 0 & 98 \\
\hline $\mathrm{Cr}$ & 2 & 4 & 4 & 2 & 89 \\
\hline $\mathrm{Cu}$ & 7 & 4 & 3 & 1 & 85 \\
\hline Dy & (a) & (a) & (a) & (a) & (a) \\
\hline Eu & (a) & (a) & (a) & (a) & (a) \\
\hline $\mathrm{Fe}$ & 0 & 0 & 0 & 0 & 100 \\
\hline Gd & (a) & (a) & (a) & (a) & (a) \\
\hline $\mathbf{K}$ & (b) & (b) & (b) & (b) & (b) \\
\hline $\mathrm{La}$ & 0 & 0 & 0 & 0 & 100 \\
\hline $\mathrm{Li}$ & 100 & 0 & 0 & 0 & 0 \\
\hline $\mathrm{Mg}$ & 3 & 0 & 0 & 0 & 97 \\
\hline Mn & 0 & 0 & 0 & 0 & 100 \\
\hline Mo & 89 & 7 & 4 & 0 & 0 \\
\hline $\mathrm{Na}$ & (c) & (c) & (c) & (c) & (c) \\
\hline Nd & 0 & 0 & 0 & 0 & 100 \\
\hline $\mathrm{Ni}$ & (b) & (b) & (b) & (b) & (b) \\
\hline $\mathbf{P}$ & 27 & 21 & 12 & 7 & 34 \\
\hline $\mathrm{Pb}$ & 0 & 0 & 0 & 0 & 100 \\
\hline Pd & (a) & (a) & (a) & (a) & (a) \\
\hline $\mathbf{R h}$ & (a) & (a) & (a) & (a) & (a) \\
\hline $\mathbf{R u}$ & 0 & 0 & 0 & 0 & 100 \\
\hline $\mathrm{Sb}$ & (a) & (a) & (a) & (a) & (a) \\
\hline $\mathrm{Se}$ & 0 & 39 & 61 & 0 & 0 \\
\hline $\mathbf{S i}$ & 0 & 0 & 0 & 0 & 99 \\
\hline Sn & 0 & 58 & 42 & 0 & 0 \\
\hline $\mathrm{Sr}$ & 0 & 0 & 0 & 0 & 100 \\
\hline $\mathrm{Te}$ & (a) & (a) & (a) & (a) & (a) \\
\hline Th & (a) & (a) & (a) & (a) & (a) \\
\hline $\mathrm{Ti}$ & 0 & 0 & 0 & 0 & 100 \\
\hline $\mathrm{Tl}$ & 0 & 33 & 47 & 21 & 0 \\
\hline $\mathbf{U}$ & 73 & 1 & 1 & 0 & 24 \\
\hline V & 0 & 53 & 25 & 22 & 0 \\
\hline$w$ & 38 & 28 & 18 & 15 & 0 \\
\hline $\mathbf{Y}$ & 0 & 0 & 0 & 0 & 100 \\
\hline Zn & 2 & 7 & 6 & 3 & 83 \\
\hline $\mathrm{Zr}$ & 1 & 0 & 0 & 0 & 99 \\
\hline
\end{tabular}

$\begin{array}{llllll}\mathrm{NO}_{3}{ }^{-} & \text {(d) } & \text { (d) } & \text { (d) } & \text { (d) } & \text { (d) } \\ \mathrm{NO}_{2}{ }^{-} & \text {(d) } & \text { (d) } & \text { (d) } & \text { (d) } & \text { (d) } \\ \mathrm{PO}_{4}{ }^{3-} & \text { (d) } & \text { (d) } & \text { (d) } & \text { (d) } & \text { (d) } \\ \mathrm{SO}_{4}{ }^{-2} & \text { (d) } & \text { (d) } & \text { (d) } & \text { (d) } & \text { (d) } \\ \mathrm{F}^{-} & \text {(d) } & \text { (d) } & \text { (d) } & \text { (d) } & \text { (d) } \\ \mathrm{Cl}^{-} & \text {(d) } & \text { (d) } & \text { (d) } & \text { (d) } & \text { (d) } \\ \mathrm{Br}^{-} & \text {(d) } & \text { (d) } & \text { (d) } & \text { (d) } & \text { (d) }\end{array}$

(a) Component was not detected.

(b) $\mathrm{K}$ and $\mathrm{Ni}$ values could not be determined due to the $\mathrm{KOH}$ fusion procedure used in the analysis of the residue.

(c) Removal of $\mathrm{Na}$ from the sludge cannot be reliably tracked because the $\mathrm{Na}$ in the sludge cannot

be distinguished from the $\mathrm{Na}$ added in the washing and leaching steps.

(d) Values could not be determined because analysis of the leached sludge was unsuccessful. 
Table C.4. Mass Balance for Nonradioactive Sludge Components From the C-103 Test

\begin{tabular}{|c|c|c|c|}
\hline \multirow[b]{2}{*}{ Component } & \multicolumn{2}{|c|}{ Concentration in Dried Sludge, $g / g$ Sludge $e^{(a)}$} & \multirow[b]{2}{*}{ Recovery, \% } \\
\hline & Direct Analysis & Summation Method & \\
\hline $\mathrm{Ag}$ & $8.60 \mathrm{E}-04$ & 9.49E-04 & 110 \\
\hline Al & $1.40 \mathrm{E}-01$ & $1.58 \mathrm{E}-01$ & 113 \\
\hline As & $<6.00 \mathrm{E}-04$ & $7.05 \mathrm{E}-05$ & \\
\hline B & $1.00 \mathrm{E}-03$ & $1.07 \mathrm{E}-03$ & 107 \\
\hline $\mathrm{Ba}$ & $2.00 \mathrm{E}-03$ & $1.19 \mathrm{E}-03$ & 60 \\
\hline $\mathrm{Be}$ & $<4.00 \mathrm{E}-05$ & $3.66 \mathrm{E}-07$ & \\
\hline $\mathbf{B i}$ & $<7.00 \mathrm{E}-04$ & $5.50 \mathrm{E}-06$ & \\
\hline $\mathrm{Ca}$ & $1.80 \mathrm{E}-02$ & $7.18 \mathrm{E}-03$ & 40 \\
\hline Cd & $8.90 \mathrm{E}-04$ & $6.04 \mathrm{E}-04$ & 68 \\
\hline $\mathrm{Ce}$ & $9.00 \mathrm{E}-04$ & 4.34E-04 & 48 \\
\hline Co & 1.00E-04 & $6.81 \mathrm{E}-05$ & 68 \\
\hline Cr & $1.60 \mathrm{E}-03$ & $1.15 \mathrm{E}-03$ & 72 \\
\hline $\mathrm{Cu}$ & $5.70 \mathrm{E}-03$ & 4.17E-03 & 73 \\
\hline Dy & $<1.00 \mathrm{E}-04$ & & \\
\hline Eu & $<7.00 \mathrm{E}-05$ & & \\
\hline $\mathrm{Fe}$ & $2.00 \mathrm{E}-01$ & $1.66 \mathrm{E}-01$ & 83 \\
\hline Gd & $<1.00 \mathrm{E}-03$ & & \\
\hline$K$ & (b) & (b) & (b) \\
\hline La & $8.00 \mathrm{E}-04$ & $5.13 \mathrm{E}-04$ & 64 \\
\hline $\mathrm{Li}$ & $<1.00 \mathrm{E}-04$ & $1.04 \mathrm{E}-05$ & \\
\hline $\mathrm{Mg}$ & $1.00 \mathrm{E}-03$ & $6.94 \mathrm{E}-04$ & 69 \\
\hline Mn & $5.80 \mathrm{E}-03$ & 4.39E-03 & 76 \\
\hline Mo & $<1.00 \mathrm{E}-04$ & $1.17 \mathrm{E}-05$ & \\
\hline $\mathbf{N a}$ & 4.60E-02 & & \\
\hline Nd & $2.00 \mathrm{E}-03$ & $1.18 \mathrm{E}-03$ & 59 \\
\hline $\mathbf{N i}$ & (b) & (b) & (b) \\
\hline $\mathbf{P}$ & $5.00 \mathrm{E}-03$ & $7.01 \mathrm{E}-03$ & 140 \\
\hline $\mathbf{P b}$ & $7.10 \mathrm{E}-03$ & $5.11 \mathrm{E}-03$ & 72 \\
\hline $\mathbf{P d}$ & $<1.00 \mathrm{E}-03$ & & \\
\hline $\mathbf{R h}$ & $<7.00 \mathrm{E}-04$ & & \\
\hline $\mathbf{R u}$ & $2.00 \mathrm{E}-03$ & $1.58 \mathrm{E}-03$ & 79 \\
\hline $\mathrm{Sb}$ & $<4.00 \mathrm{E}-04$ & & \\
\hline Se & $<5.00 \mathrm{E}-04$ & $6.49 \mathrm{E}-06$ & \\
\hline $\mathrm{Si}$ & $2.70 \mathrm{E}-02$ & $2.70 \mathrm{E}-02$ & 100 \\
\hline Sn & $<7.00 \mathrm{E}-03$ & 7.17E-05 & \\
\hline Sr & $2.00 \mathrm{E}-104$ & $1.58 \mathrm{E}-04$ & 79 \\
\hline $\mathrm{Te}$ & $<1.00 \mathrm{E}-03$ & & \\
\hline Th & $<6.00 \mathrm{E}-03$ & & \\
\hline $\mathbf{T i}$ & $4.10 \mathrm{E}-04$ & 3.32E-04 & 81 \\
\hline $\mathrm{Tl}$ & $<4.00 \mathrm{E}-03$ & $1.28 \mathrm{E}-04$ & \\
\hline $\mathrm{U}$ & 3.05E-03 & $5.61 \mathrm{E}-03$ & 184 \\
\hline $\mathbf{v}$ & $<7.00 \mathrm{E}-05$ & $3.76 \mathrm{E}-06$ & \\
\hline w & $<6.00 \mathrm{E}-04$ & $5.39 \mathrm{E}-05$ & \\
\hline $\mathbf{Y}$ & $3.00 \mathrm{E}-04$ & $1.58 \mathrm{E}-04$ & 53 \\
\hline Zn & $7.00 \mathrm{E}-04$ & $4.73 \mathrm{E}-04$ & 68 \\
\hline $\mathrm{Zr}$ & 2.30E-02 & $1.72 \mathrm{E}-02$ & 75 \\
\hline
\end{tabular}

\begin{tabular}{llll}
$\mathrm{NO}_{3}{ }^{-}$ & (c) & (c) & (c) \\
$\mathrm{NO}_{2}{ }^{-}$ & (c) & (c) & (c) \\
$\mathrm{PO}_{4}{ }^{3-}$ & (c) & (c) & (c) \\
$\mathrm{SO}_{4}{ }^{2-}$ & (c) & (c) & (c) \\
$\mathrm{F}^{-}$ & (c) & (c) & (c) \\
$\mathrm{Cl}^{-}$ & (c) & (c) & (c) \\
$\mathrm{Br}^{-}$ & (c) & (c) \\
\hline (a) Blank spaces indicate that the analyte was below the detection limit. & \\
(b) K and Ni values could not be determined due to the KOH fusion & \\
procedure used in the analysis of the residue. &
\end{tabular}

C. 6 
Table C.5. Concentrations of the Radioactive Sludge Components in the Various Process Streams From the C-103 Test

Concentration, $\mu \mathrm{Ci} / \mathrm{mL}$

\begin{tabular}{|c|c|c|c|c|}
\hline Component & $\begin{array}{c}\text { Retrieval } \\
\text { Solution (E) }\end{array}$ & $\begin{array}{c}\text { First Caustic } \\
\text { Leach (G) }\end{array}$ & $\begin{array}{c}\text { Second Caustic } \\
\text { Leach (I) }\end{array}$ & Wash $(\mathrm{K})$ \\
\hline Total Alpha & $6.67 \mathrm{E}-03$ & $<2.55 \mathrm{E}-04$ & 4.74E-04 & $1.84 \mathrm{E}-04$ \\
\hline${ }^{239,240} \mathrm{Pu}$ & $2.36 \mathrm{E}-03$ & $<2.55 \mathrm{E}-04$ & $<2.55 \mathrm{E}-04$ & $1.09 \mathrm{E}-04$ \\
\hline${ }^{241} \mathrm{Am}+{ }^{238} \mathrm{Pu}$ & $4.31 \mathrm{E}-03$ & $<2.55 \mathrm{E}-04$ & $4.74 \mathrm{E}-04$ & $7.60 \mathrm{E}-05$ \\
\hline${ }^{241} \mathrm{Am}(\gamma)$ & 3.37E-03 & $<1.70 \mathrm{E}-02$ & $<3.40 \mathrm{E}-03$ & $<1.70 \mathrm{E}-03$ \\
\hline${ }^{137} \mathrm{Cs}$ & $4.31 \mathrm{E}+00$ & $2.80 \mathrm{E}+01$ & $1.94 \mathrm{E}+01$ & $4.39 \mathrm{E}+\infty$ \\
\hline${ }^{90} \mathrm{Sr}$ & $9.27 \mathrm{E}-01$ & $1.14 \mathrm{E}-01$ & $1.25 \mathrm{E}-01$ & $1.90 \mathrm{E}-02$ \\
\hline${ }^{99} \mathrm{Tc}$ & $2.90 \mathrm{E}-03$ & $1.26 \mathrm{E}-03$ & $5.71 \mathrm{E}-04$ & $1.21 \mathrm{E}-04$ \\
\hline
\end{tabular}

Concentration, $\mu \mathrm{Ci} / \mathrm{g}$

$\frac{\text { Component }}{\text { Total Alpha }}$
${ }_{239,240} \mathrm{Pu}$
${ }^{241} \mathrm{Am}+{ }^{238} \mathrm{Pu}$
${ }^{241} \mathrm{Am}(\gamma)$
${ }^{137} \mathrm{Cs}$
${ }^{90} \mathrm{Sr}$
${ }^{99} \mathrm{Tc}$

Residue

2.53E+01

$4.20 \mathrm{E}+00$

$2.07 \mathrm{E}+01$

$1.95 \mathrm{E}+01$

$1.88 \mathrm{E}+02$

$9.91 \mathrm{E}+03$

6.27E-03 
Table C.6. Distribution of the Radioactive Sludge Components Between the Various Process Streams From the C-103 Test

Amount of Component Found, \%

\begin{tabular}{|c|c|c|c|c|c|}
\hline Component & $\begin{array}{c}\text { Retrieval } \\
\text { Solution (E) }\end{array}$ & $\begin{array}{c}\text { First Caustic } \\
\text { Leach }(G)\end{array}$ & $\begin{array}{c}\text { Second Caustic } \\
\text { Leach (I) }\end{array}$ & Wash $(\mathrm{K})$ & Residue (A) \\
\hline Total Alpha & 0 & 0 & 0 & 0 & 100 \\
\hline${ }^{239,240} \mathrm{Pu}$ & 1 & 0 & 0 & 0 & 99 \\
\hline${ }^{241} \mathrm{Am}+{ }^{238} \mathrm{Pu}$ & 0 & 0 & 0 & 0 & 100 \\
\hline${ }^{241} \mathrm{Am}(\gamma)$ & 0 & 0 & 0 & 0 & 100 \\
\hline${ }^{137} \mathrm{Cs}$ & 20 & 10 & 9 & 5 & 56 \\
\hline${ }^{90} \mathrm{Sr}$ & 0 & 0 & 0 & 0 & 100 \\
\hline${ }^{99} \mathrm{Tc}$ & 83 & 3 & 2 & 1 & 12 \\
\hline
\end{tabular}

Table C.7. Mass Balance for Radioactive Sludge Components From the C-103 Test

\begin{tabular}{|c|c|c|c|}
\hline \multirow[b]{2}{*}{ Component } & \multicolumn{2}{|c|}{ Concentration in Dried Sludge, $\mu \mathrm{Ci} / \mathrm{g}$} & \multirow[b]{2}{*}{ Recovery, \% } \\
\hline & Direct Analysis & Summation Method & \\
\hline Total Alpha & $2.79 \mathrm{E}+01$ & $2.00 \mathrm{E}+01$ & 72 \\
\hline${ }^{239,240} \mathrm{Pu}$ & $4.85 \mathrm{E}+\infty 0$ & $3.34 \mathrm{E}+\infty 0$ & 69 \\
\hline${ }^{241} \mathrm{Am}+{ }^{238} \mathrm{Pu}$ & $2.27 \mathrm{E}+01$ & $1.64 \mathrm{E}+01$ & 72 \\
\hline${ }^{241} \mathrm{Am}(\gamma)$ & $2.19 \mathrm{E}+01$ & $1.54 \mathrm{E}+01$ & 70 \\
\hline${ }^{137} \mathrm{Cs}$ & $2.36 \mathrm{E}+02$ & $2.65 \mathrm{E}+02$ & 112 \\
\hline${ }^{90} \mathrm{Sr}$ & $9.86 \mathrm{E}+03$ & $7.82 \mathrm{E}+03$ & 79 \\
\hline${ }^{99} \mathrm{Tc}$ & $2.10 \mathrm{E}-02$ & $4.26 \mathrm{E}-02$ & 203 \\
\hline
\end{tabular}



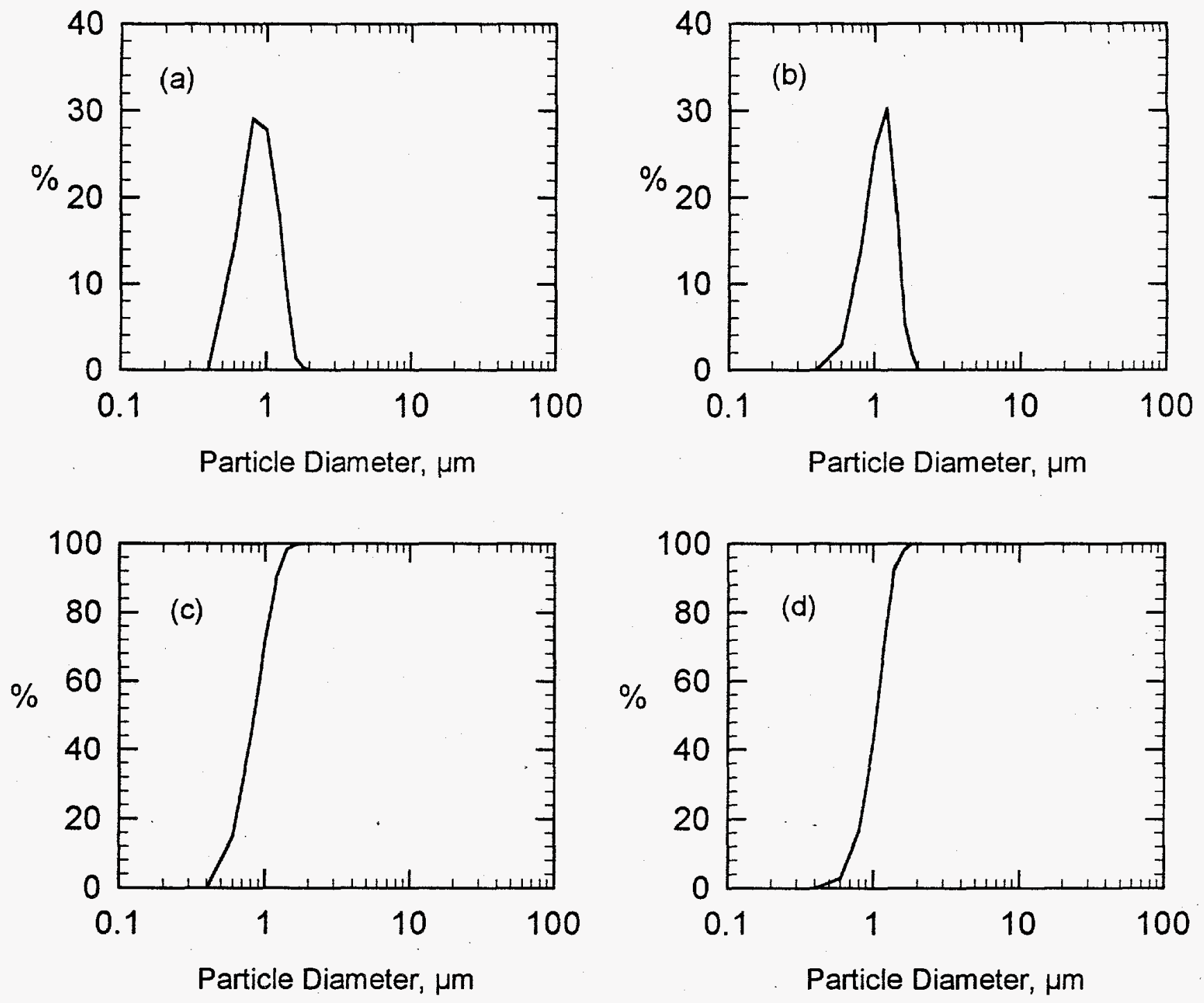

C103-2C.SPW

Figure C.2. Particle-Size Data for Untreated C-103 Sludge: a) Probability-Number Density Graph, b) Probability-Volume Density Graph, c) Probability-Number Distribution Graph, and d) Probability-Volume Distribution Graph. 

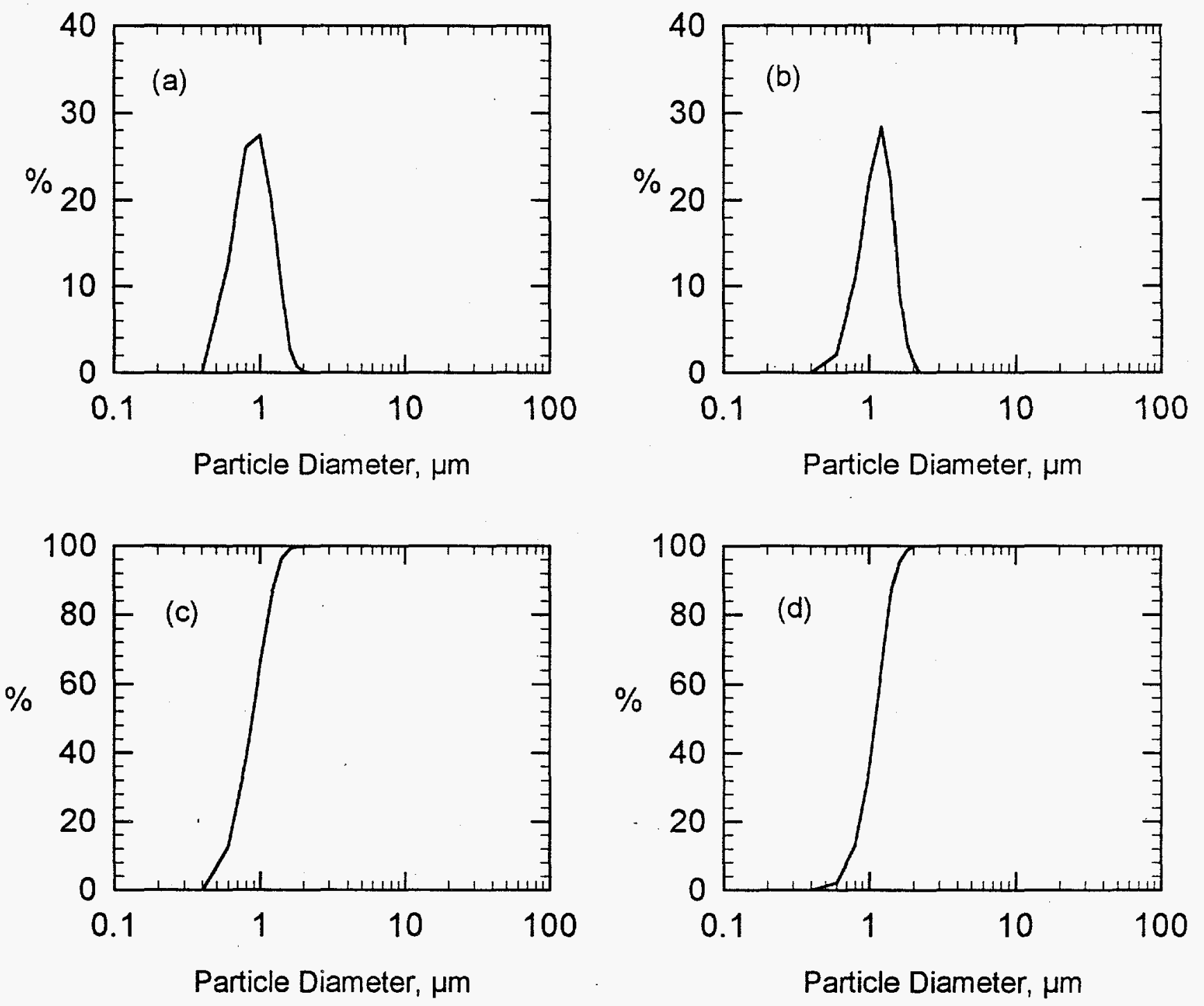

C103-1M.SPW

Figure C.3. Particle-Size Data for Treated C-103 Sludge: a) Probability-Number Density Graph, b) Probability-Volume Density Graph, c) Probability-Number Distribution Graph, and d) Probability-Volume Distribution Graph. 


\section{Appendix D}

Results from the Tank S-104 Sludge

Washing and Caustic Leaching Test 


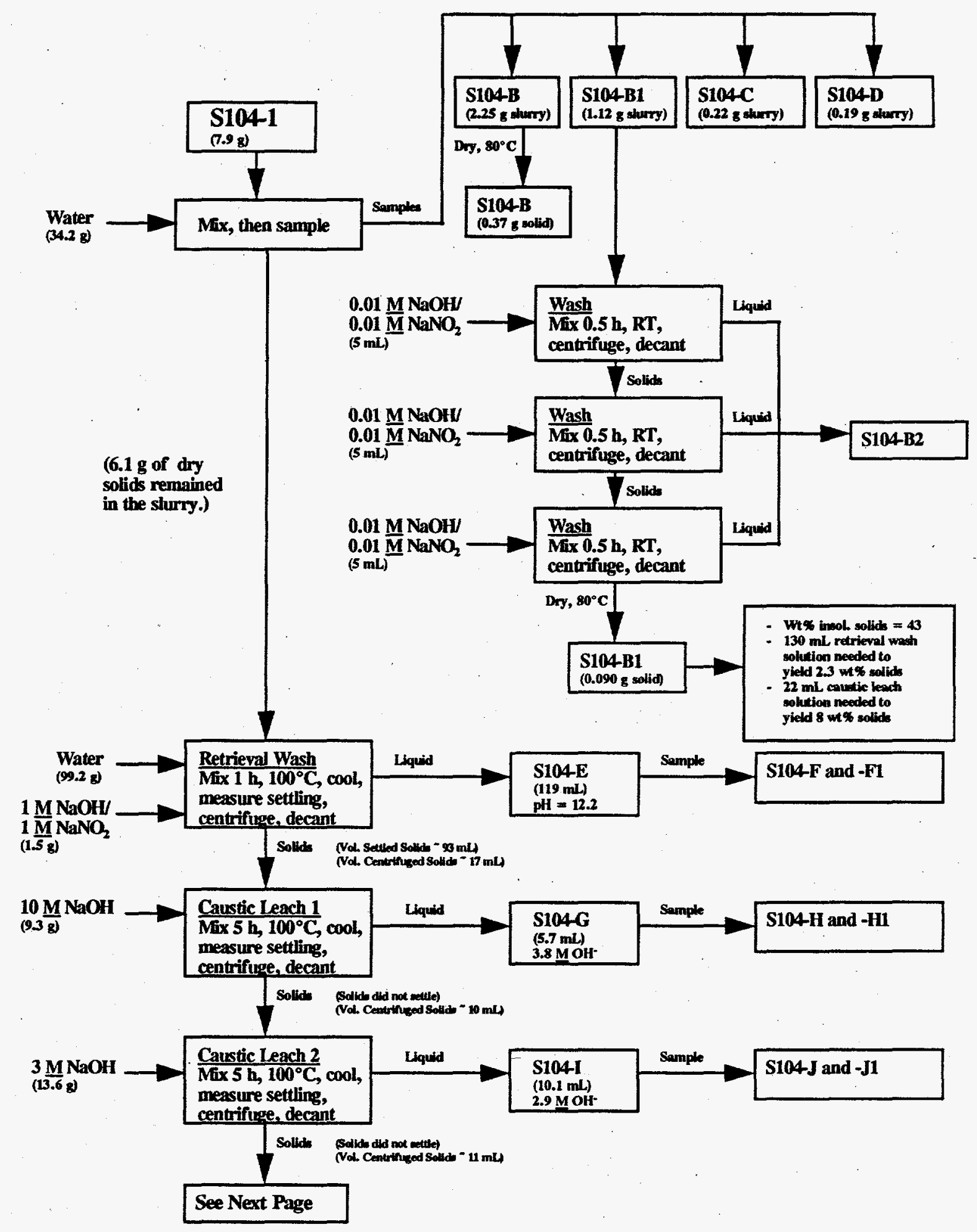

Figure D.1. Schematic of S-104 Sludge Washing and Caustic Leaching Test

D.1 


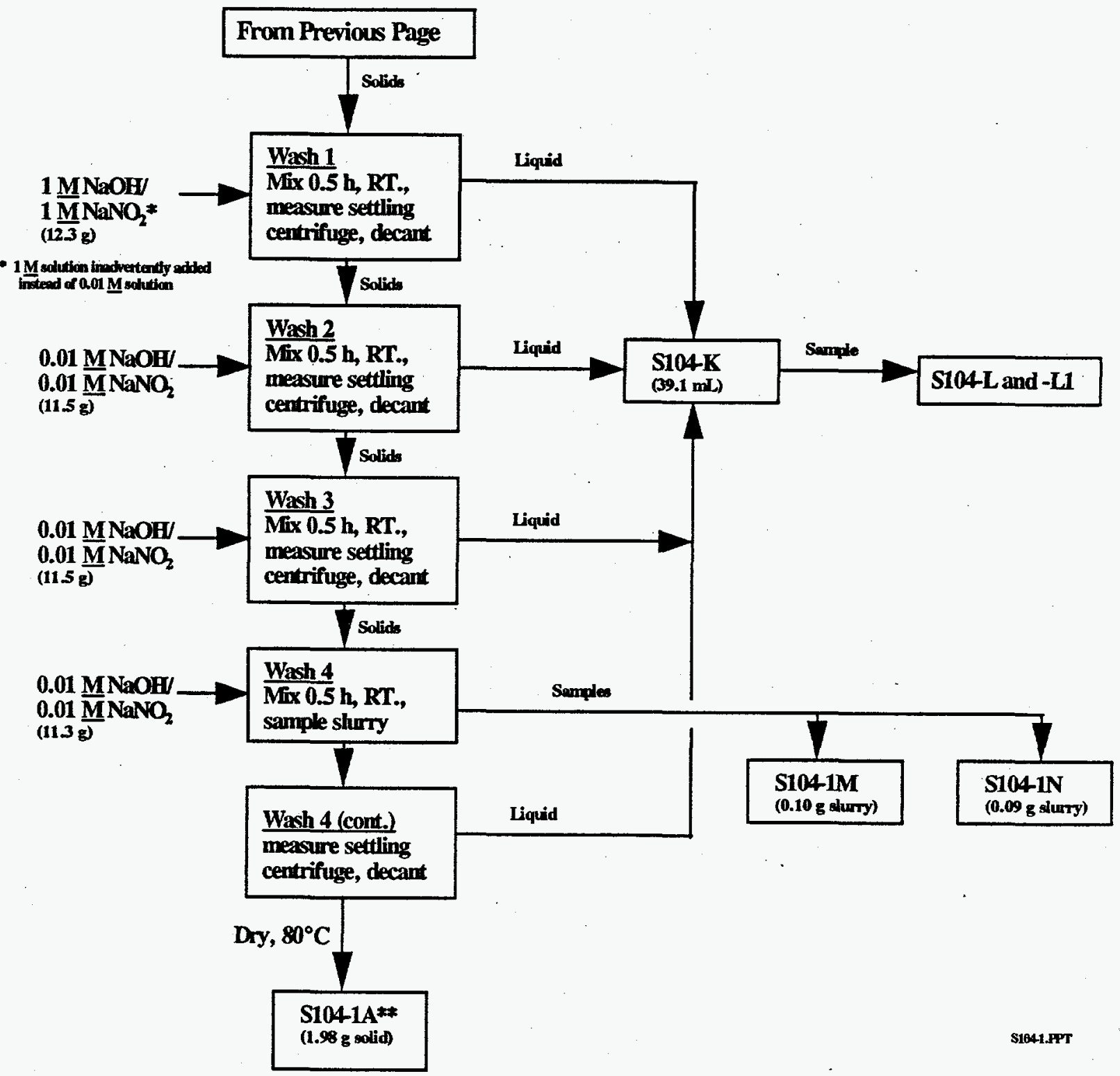

Figure D.1. (contd.) 
Table D.1. Concentrations of the Nonradioactive Sludge Components in the Various Process Solutions From the S-104 Test

\begin{tabular}{|c|c|c|c|c|c|c|}
\hline & & & & Concet & on, $\mu \mathrm{g} / \mathrm{mL}$ & \\
\hline Component & & $\begin{array}{c}\text { Detection } \\
\text { Limit, } \mu \mathrm{g} / \mathrm{mL} \\
\end{array}$ & $\begin{array}{l}\text { Retrieval Solution } \\
\text { (E) } \\
\end{array}$ & $\begin{array}{c}\text { First Caustic } \\
\text { Leach (G) }\end{array}$ & $\begin{array}{c}\text { Second Caustic } \\
\text { Leach (I) }\end{array}$ & Wash (K) \\
\hline $\mathbf{A g}$ & & 0.17 & $\mathbf{0}$ & $\mathbf{0}$ & $\mathbf{0}$ & 0 \\
\hline Al & & 0.85 & 289 & 18700 & 13600 & 3060 \\
\hline As & & 1.7 & 0 & 42.5 & 27.2 & 6.8 \\
\hline B & & 0.34 & 0 & 0 & 0.425 & 0 \\
\hline $\mathbf{B a}$ & & 0.17 & 0 & 0 & 0 & 0 \\
\hline $\mathrm{Be}$ & & 0.085 & 0 & 0 & 0 & 0 \\
\hline $\mathbf{B i}$ & & 1.7 & 0 & 0 & 0 & 0 \\
\hline $\mathrm{Ca}$ & & 0.85 & 10.2 & 0 & 5.1 & 17.85 \\
\hline Cd & • & 0.17 & 0 & 0 & 0 & 0 \\
\hline $\mathrm{Ce}$ & & 1.7 & 0 & 0 & 0 & 0 \\
\hline Co & & 0.17 & 0 & 0 & 0 & 0 \\
\hline $\mathrm{Cr}$ & & 0.34 & 195.5 & 110.5 & 47.6 & 11.9 \\
\hline $\mathrm{Cu}$ & & 0.17 & 0 & 0 & 0.85 & 0 \\
\hline Dy & & 0.34 & 0 & 0 & 0 & 0 \\
\hline $\mathbf{E u}$ & & 0.17 & 0 & 0 & 0 & 0 \\
\hline $\mathbf{F e}$ & & 0.17 & 0.425 & 17 & 5.61 & 0.85 \\
\hline Gd & & 3.4 & 0 & 0 & $\mathbf{0}$ & 0 \\
\hline $\mathbf{K}$ & & 25.5 & 0 & 0 & 0 & 0 \\
\hline La & & 0.51 & 0 & 0 & 0 & 0 \\
\hline $\mathbf{L i}$ & & 0.34 & 0 & 0 & 0 & 0 \\
\hline $\mathbf{M g}$ & & 1.7 & 0 & 0 & 0 & 0 \\
\hline $\mathrm{Ma}$ & & 0.085 & 0 & 0 & 0 & 0 \\
\hline Mo & & 0.34 & 0 & 0 & 0.425 & 0 \\
\hline $\mathbf{N a}$ & & 1.7 & 8160 & 110500 & 85000 & 31450 \\
\hline Nd & & 0.51 & 0 & 0 & 0 & 0 \\
\hline $\mathbf{N i}$ & & 0.51 & 0 & 0 & 0 & 0 \\
\hline $\mathbf{P}$ & & 1.7 & 0 & 0 & 0 & 0 \\
\hline $\mathrm{Pb}$ & & 0.85 & 0 & 0 & 0 & 0 \\
\hline Pd & & 2.55 & 0 & 0 & 0 & 0 \\
\hline $\mathbf{R h}$ & & 1.7 & 0 & 0 & 0 & 0 \\
\hline $\mathbf{R u}$ & & 1.7 & 0 & 0 & 0 & 0 \\
\hline Sb & & 0.85 & 0 & 0 & 0 & 0 \\
\hline Se & & 1.7 & 0 & 0 & 5.1 & 0 \\
\hline Si & & 0.85 & 0 & 0 & 0 & 0 \\
\hline Sn & & 17 & 0 & 0 & 0 & 0 \\
\hline Sr & & 0.085 & 0 & 0 & 0.17 & 0 \\
\hline $\mathrm{Te}$ & & 3.4 & 0 & 0 & 0 & 0 \\
\hline $\mathbf{T h}$ & & 17 & 0 & 0 & 0 & 0 \\
\hline $\mathbf{T i}$ & & 0.085 & 0 & 0 & 0 & 0 \\
\hline $\mathbf{T I}$ & $\cdot$ & 8.5 & 0 & 0 & 25.5 & 0 \\
\hline $\mathbf{U}$ & & 0.00255 & 0.02618 & 0.80495 & 0.7004 & 0.2431 \\
\hline $\mathbf{v}$ & & 0.17 & 0 & 0 & 0 & 0 \\
\hline $\mathbf{w}$ & & 1.7 & 0 & 0 & 0 & 0 \\
\hline $\mathbf{Y}$ & & 0.17 & 0 & 0 & 0 & 0 \\
\hline $\mathbf{Z n}_{\mathbf{n}}$ & & 0.34 & 4.25 & 4.25 & 2.55 & 3.4 \\
\hline Zr & & 0.17 & 0 & 0 & 0 & 0 \\
\hline $\mathrm{NO}_{3}{ }^{-}$ & & 250 & 11700 & 6100 & 2540 & 580 \\
\hline $\mathrm{NO}_{2}^{-}$ & & 100 & 2600 & 1220 & 570 & 11200 \\
\hline $\mathrm{PO}_{4}{ }^{3-}$ & . & 25 & 0 & 0 & 0 & 0 \\
\hline $\mathrm{SO}_{4}^{2-}$ & & 25 & 100 & 0 & 0 & 0 \\
\hline$F^{*}$ & & 12.5 & 0 & 0 & 0 & 0 \\
\hline $\mathrm{Cl}^{-}$ & & 12.5 & 190 & 60 & 30 & 30 \\
\hline $\mathbf{B r}$ & & 12.5 & 0 & 0 & 0 & 0 \\
\hline
\end{tabular}

(a) The detection limit for the first caustic leach solution (G) was ten times the values reported in the column.

(b) Unless otherwise indicated, zero values indicate the analyte was below the detection limit. 
Table D.2. Concentrations of the Nonradioactive Sludge Components in the Leached Sludge From the S-104 Test

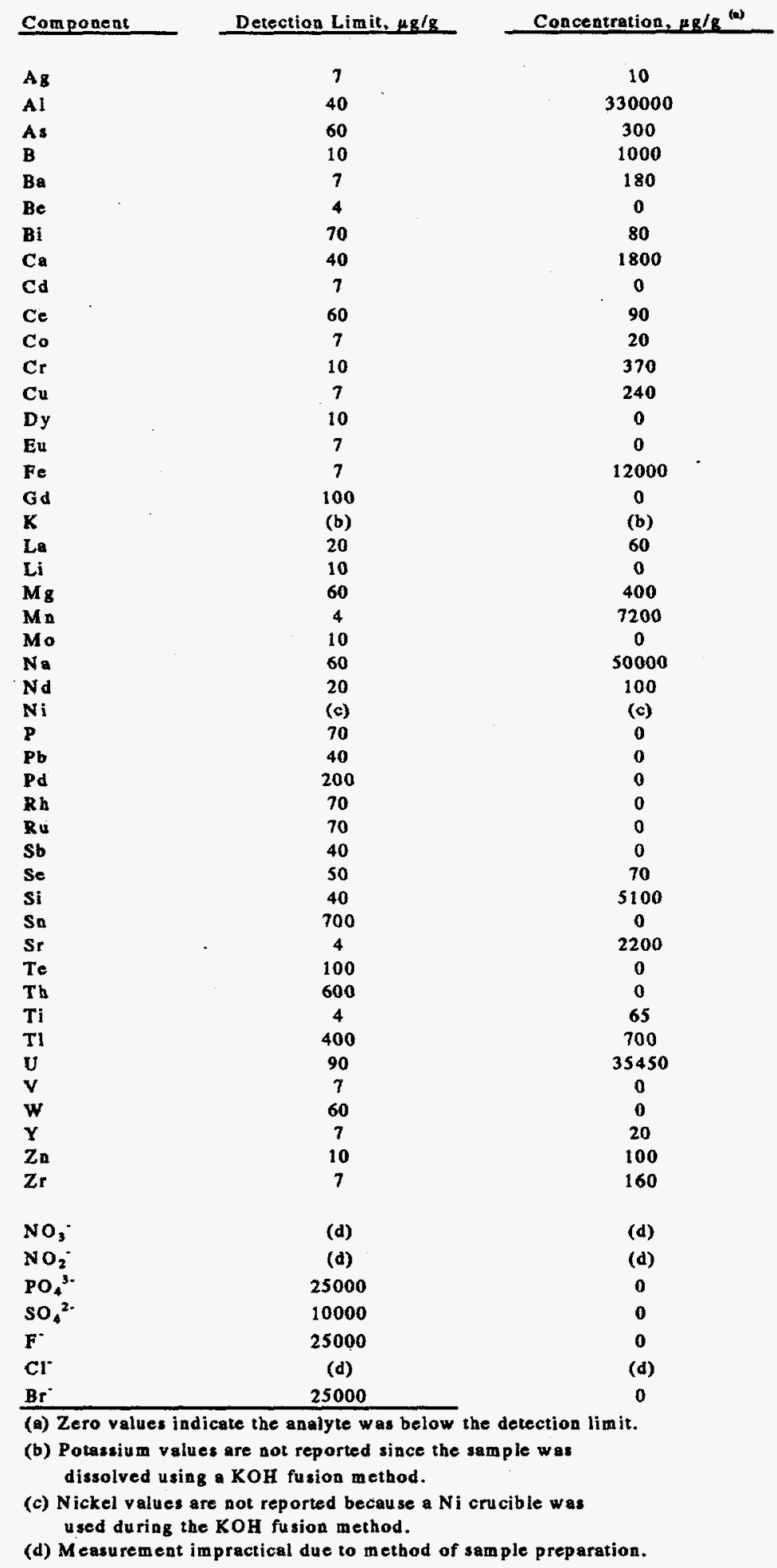

\section{D.4}


Table D.3. Distribution of the Nonradioactive Sludge Components Between the Various Process Streams From the S-104 Test

\begin{tabular}{|c|c|c|c|c|c|}
\hline \multirow[b]{2}{*}{ Component } & \multicolumn{5}{|c|}{ A mount of Component Found, $x$} \\
\hline & $\begin{array}{c}\text { Retrieval } \\
\text { Solution (E) }\end{array}$ & $\begin{array}{c}\text { First Caustic } \\
\text { Leach (O) }\end{array}$ & $\begin{array}{c}\text { Second Caustic } \\
\text { Leach (I) }\end{array}$ & Wash (K) & Residue (A) \\
\hline Ag & 0 & 0 & 0 & 0 & 100 \\
\hline Al & 3 & 10 & 12 & 13 & 62 \\
\hline As & 0 & 16 & 19 & 23 & 42 \\
\hline B & 0 & 0 & 0 & 0 & 100 \\
\hline Ba & $\mathbf{0}$ & 0 & $\mathbf{0}$ & $\mathbf{0}$ & 100 \\
\hline Be & (a) & (a) & (a) & (a) & (a) \\
\hline Bi & 0 & 0 & 0 & 0 & 100 \\
\hline $\mathrm{Ca}$ & 21 & $\mathbf{0}$ & 1 & 15 & 64 \\
\hline Cd & (a) & (a) & (a) & (a) & (a) \\
\hline $\mathrm{Ce}$ & 0 & 0 & 0 & $\mathbf{0}$ & 100 \\
\hline co & 0 & 0 & 0 & o & 100 \\
\hline $\mathrm{Cr}$ & 90 & 2 & 2 & 2 & 3 \\
\hline $\mathrm{Cu}$ & 0 & 0 & 2 & $\mathbf{0}$ & 98 \\
\hline Dy & (a) & (a) & (a) & (a) & (a) \\
\hline $\mathrm{Eu}$ & (a) & (a) & (a) & (a) & (a) \\
\hline $\mathrm{Fe}$ & 0 & 0 & 0 & 0 & 99 \\
\hline Gd & (a) & (a) & (a) & (a) & (a) \\
\hline $\mathbf{K}$ & (b) & (b) & (b) & (b) & (b) \\
\hline $\mathrm{La}$ & 0 & 0 & 0 & 0 & 100 \\
\hline $\mathrm{Li}$ & (a) & (a) & (a) & (a) & (a) \\
\hline $\mathbf{M g}$ & 0 & 0 & 0 & 0 & 100 \\
\hline$M n$ & 0 & o & 0 & 0 & 100 \\
\hline Mo & 0 & $\mathbf{0}$ & 100 & 0 & 0 \\
\hline $\mathrm{Na}$ & (c) & (c) & (c) & (c) & (c) \\
\hline Nd & 0 & 0 & 0 & 0 & 100 \\
\hline $\mathbf{N i}$ & (b) & (b) & (b) & (b) & (b) \\
\hline $\mathbf{P}$ & (a) & (a) & (a) & (a) & (a) \\
\hline $\mathrm{Pb}$ & (a) & (a) & (a) & (a) & (a) \\
\hline Pd & (a) & (a) & (a) & (a) & (a) \\
\hline $\mathbf{R h}$ & (a) & (a) & (a) & (a) & (a) \\
\hline Ru & (a) & (a) & (a) & (a) & (a) \\
\hline sb & (a) & (a) & (a) & (a) & (a) \\
\hline se & 0 & 0 & 26 & 0 & 74 \\
\hline si & 0 & o . & 0 & 0 & 100 \\
\hline sn & (a) & (a) & (a) & (a) & (a) \\
\hline Sr & 0 & 0 & 0 & 0 & 100 \\
\hline $\mathrm{Te}$ & (a) & (a) & (a) & (a) & (a) \\
\hline Th & (a) & (a) & (a) & (a) & (a) \\
\hline $\mathrm{Ti}$ & 0 & 0 & 0 & 0 & 100 \\
\hline T1 & 0 & 0 & 15 & 0 & 85 \\
\hline $\mathbf{u}$ & $\mathbf{0}$ & 0 & 0 & 0 & 100 \\
\hline $\mathbf{v}$ & (a) & (a) & (a) & (a) & (a) \\
\hline$w$ & (a) & (a) & (a) & (a) & (a) \\
\hline $\mathbf{Y}$ & 0 & 0 & 0 & 0 & 100 \\
\hline $\mathrm{Zn}_{\mathbf{n}}$ & 54 & 3 & 3 & 18 & 22 \\
\hline $\mathrm{Zr}_{\mathrm{r}}$ & 0 & 0 & 0 & 0 & 100 \\
\hline $\mathrm{NO}_{3}^{-}$ & 94 & 2 & 2 & 2 & (d) \\
\hline $\mathrm{NO}_{2}^{-}$ & 36 & 1 & 1 & 63 & (d) \\
\hline $\mathrm{PO}_{4}^{3}$ & (a) & (a) & (a) & (a) & (a) \\
\hline $\mathrm{SO}_{4}{ }^{2-}$ & $100(35)^{(e)}$ & 0 & $0(1)^{(1)}$ & $0(4)^{(0)}$ & $0(61)^{(\theta)}$ \\
\hline$F^{-}$ & (a) & (a) & (a) & (a) & (a) \\
\hline $\mathrm{Cl}^{-}$ & 91 & 1 & 1 & 6 & (d) \\
\hline $\mathrm{Br}$ & (a) & (a) & (a) & (a) & (a) \\
\hline
\end{tabular}

(a) Component was not deteoled.

(b) $\mathrm{K}$ and $\mathrm{Ni}$ valuen could not be determined due to the $\mathrm{KOH}$ fusion procedure used to prepare the leached sludge for analysis.

(c) Removal of $\mathrm{Na}$ from the sludge cannot bo reliably tracked because the $\mathrm{Na}$ in the sludge cannot be distinguished from the $\mathrm{Na}$ added in the washing and leaching steps.

(d) Measurement impractical due to method of sample preparation.

(e) Values in parenthanes reprosent the values obtained if, for cases where the component was below the detection limit, the component concentration was assumed to be the detection limit. 
Table D.4. Mass Balance for Nonradioactive Sludge Components From the S-104 Test

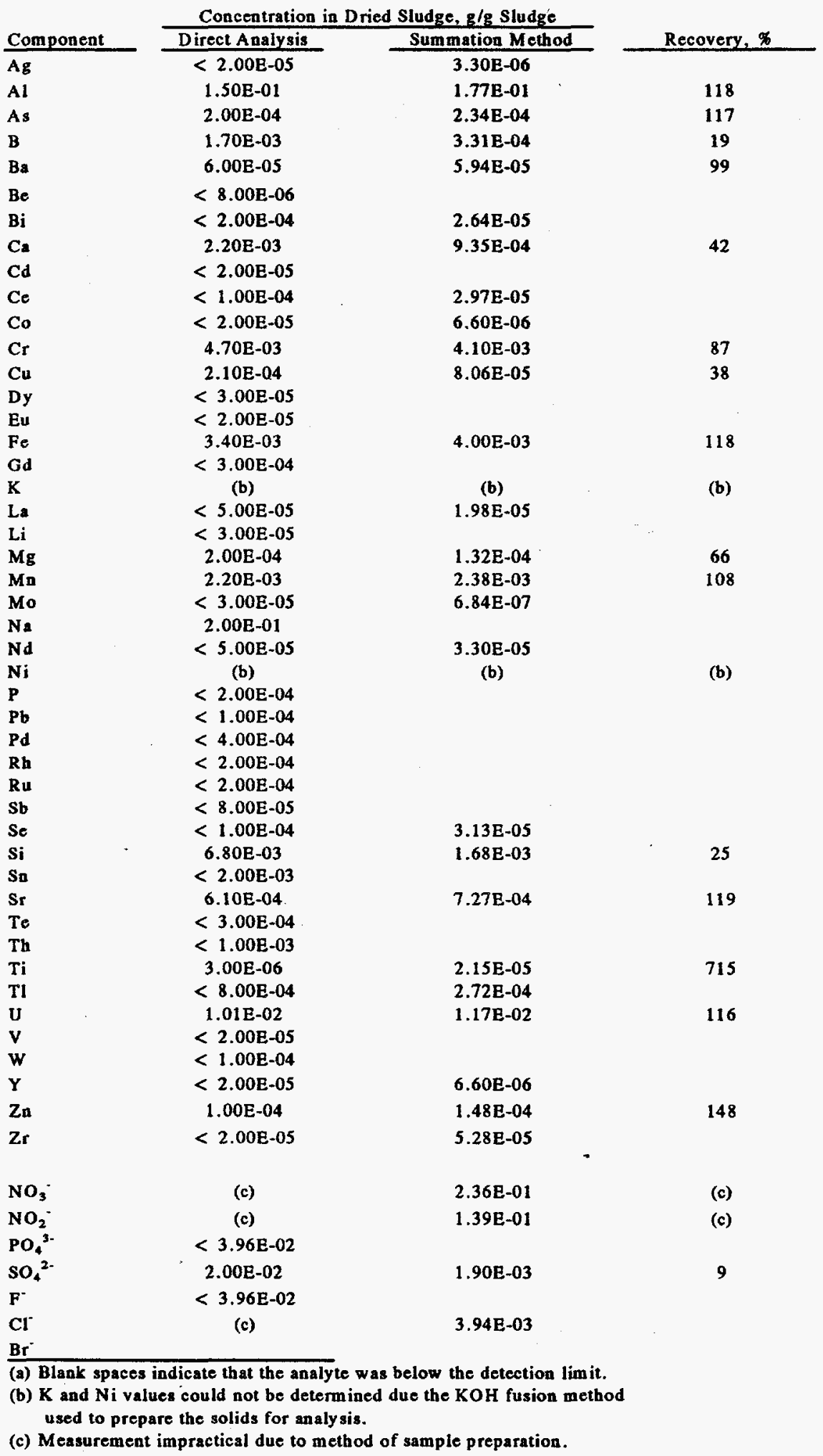

D.6 
Table D.5. Concentrations of the Radioactive Sludge Components in the Various Process Streams From the S-104 Test

\begin{tabular}{|c|c|c|c|c|}
\hline \multirow[b]{2}{*}{ Component } & \multicolumn{4}{|c|}{ Concentration, $\mu \mathrm{Ci} / \mathrm{mL}$} \\
\hline & $\begin{array}{c}\text { Retrieval } \\
\text { Solution (E) }\end{array}$ & $\begin{array}{c}\text { First Caustic } \\
\text { Leach (G) }\end{array}$ & $\begin{array}{l}\text { Second Caustic } \\
\text { Leach (I) }\end{array}$ & Wash (K) \\
\hline Total Alpha & $<1.7 \mathrm{E}-05$ & $<1.7 \mathrm{E}-05$ & $<2.55 \mathrm{E}-05$ & $<2.55 \mathrm{E}-05$ \\
\hline${ }^{239,240} \mathrm{Pu}$ & $\mathrm{ND}^{(\mathrm{a})}$ & ND & ND & ND \\
\hline${ }^{241} \mathrm{Am}+{ }^{238} \mathrm{Pu}$ & ND & ND & ND & ND \\
\hline${ }^{241} \mathrm{Am}(\gamma)$ & $<2.00 \mathrm{E}-04$ & $<2.00 \mathrm{E}-04$ & $<9.00 \mathrm{E}-05$ & $<4.00 \mathrm{E}-05$ \\
\hline${ }^{137} \mathrm{Cs}$ & $4.16 \mathrm{E}+\infty$ & $2.91 \mathrm{E}+\infty$ & $1.23 E+\infty$ & $2.82 \mathrm{E}-01$ \\
\hline${ }^{90} \mathrm{Sr}$ & $2.13 E-03$ & $4.51 E-02$ & $9.35 E-02$ & $2.64 \overline{\mathrm{E}}-02$ \\
\hline \multirow[t]{2}{*}{${ }^{99} \mathrm{Tc}$} & $1.59 \mathrm{E}-03$ & $7.48 \mathrm{E}-04$ & $3.13 E-04$ & 7.17E-05 \\
\hline & \multicolumn{3}{|c|}{ Concentration, $\mu \mathrm{Ci} / \mathrm{g}$} & \\
\hline Component & & Residue & & \\
\hline Total Alpha & & $2.72 E+00$ & & \\
\hline${ }^{239,240} \mathrm{Pu}$ & & $2.02 \mathrm{E}+\infty 0$ & & \\
\hline${ }^{241} \mathrm{Am}+{ }^{238} \mathrm{Pu}$ & & $7.00 \mathrm{E}-01$ & & \\
\hline${ }^{241} \mathrm{Am}(\gamma)$ & & $7.29 \mathrm{E}-01$ & & \\
\hline${ }^{137} \mathrm{Cs}$ & & $6.01 E+\infty$ & & \\
\hline${ }^{90} \mathrm{Sr}$ & & $1.63 E+03$ & & \\
\hline${ }^{99} \mathrm{Tc}$ & & $<5.00 \mathrm{E}-04$ & & \\
\hline
\end{tabular}

(a) $\mathrm{ND}=$ Not Determined. The low total alpha activity made these separations impractical.

D.7 
Table D.6. Distribution of the Radioactive Sludge Components Between the Various Process Streams From the S-104 Test

\begin{tabular}{|c|c|c|c|c|c|}
\hline \multirow[b]{2}{*}{ Component } & \multicolumn{5}{|c|}{ Amount of Component Found, $\%$} \\
\hline & $\begin{array}{c}\text { Retrieval } \\
\text { Solution (E) }\end{array}$ & $\begin{array}{l}\text { First Caustic } \\
\text { Leach }(\mathbf{G})\end{array}$ & $\begin{array}{l}\text { Second Caustic } \\
\text { Leach (I) }\end{array}$ & Wash (K) & Residue (A) \\
\hline Total Alpha & 0 & 0 & 0 & $\mathbf{0}$ & 100 \\
\hline${ }^{239,240} \mathrm{Pu}$ & (a) & (a) & (a) & (a) & 100 \\
\hline${ }^{241} \mathrm{Am}+{ }^{238} \mathrm{Pu}$ & (a) & (a) & (a) & (a) & 100 \\
\hline${ }^{241} \operatorname{Am}(\gamma)$ & 0 & 0 & 0 & 0 & 100 \\
\hline${ }^{137} \mathrm{Cs}$ & 90 & 3 & 2 & 3 & 2 \\
\hline${ }^{90} \mathrm{Sr}$ & 0 & 0 & 0 & 0 & 100 \\
\hline${ }^{99} \mathrm{Tc}$ & 95 & 2 & 2 & 2 & 0 \\
\hline
\end{tabular}

(a) Not determined due to a lack of total alpha activity in the components

Table D.7. Mass Balance for Radioactive Sludge Components From the S-104 Test

\begin{tabular}{|c|c|c|c|}
\hline \multirow[b]{2}{*}{ Component } & \multicolumn{2}{|c|}{ Concentration in Dried Sludge, $\mu \mathrm{Ci} / \mathrm{g}$} & \multirow[b]{2}{*}{ Recovery, \% } \\
\hline & Direct Analysis & Summation Method & \\
\hline Total Alpha & $7.29 \mathrm{E}-01$ & $8.96 \mathrm{E}-01$ & 123 \\
\hline${ }^{239,240} \mathrm{Pu}$ & $5.45 \mathrm{E}-01$ & $6.65 \mathrm{E}-01$ & 122 \\
\hline${ }^{241} \mathrm{Am}+{ }^{238} \mathrm{Pu}$ & $1.84 \mathrm{E}-01$ & $2.31 E-01$ & 126 \\
\hline${ }^{241} \mathrm{Am}(\gamma)$ & $2.49 \mathrm{E}-01$ & $2.41 E-01$ & 97 \\
\hline${ }^{137} \mathrm{Cs}$ & $9.16 \mathrm{E}+01$ & $8.77 \mathrm{E}+01$ & 96 \\
\hline${ }^{90} \mathrm{Sr}$ & $4.91 \mathrm{E}+02$ & $5.39 \mathrm{E}+02$ & 110 \\
\hline${ }^{99} \mathrm{Tc}$ & $2.70 \mathrm{E}-02$ & $3.19 \mathrm{E}-02$ & 118 \\
\hline
\end{tabular}



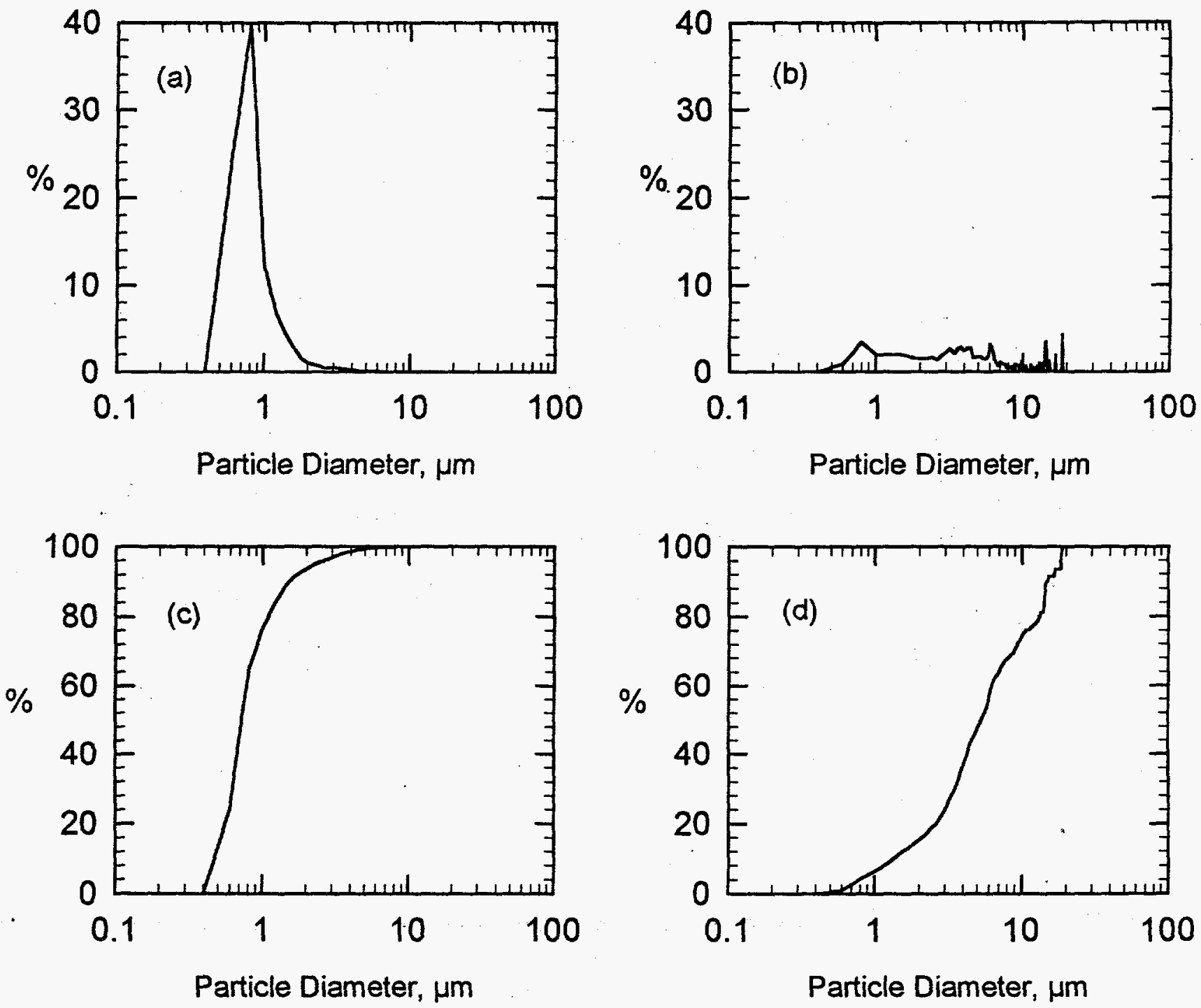

S104-CO2.SPW

Figure D.2. Particle-Size Data for Untreated S-104 Sludge: a) Probability-Number Density Graph, b) Probability-Volume Density Graph, c) Probability-Number Distribution Graph, and d) Probability-Volume Distribution Graph. 

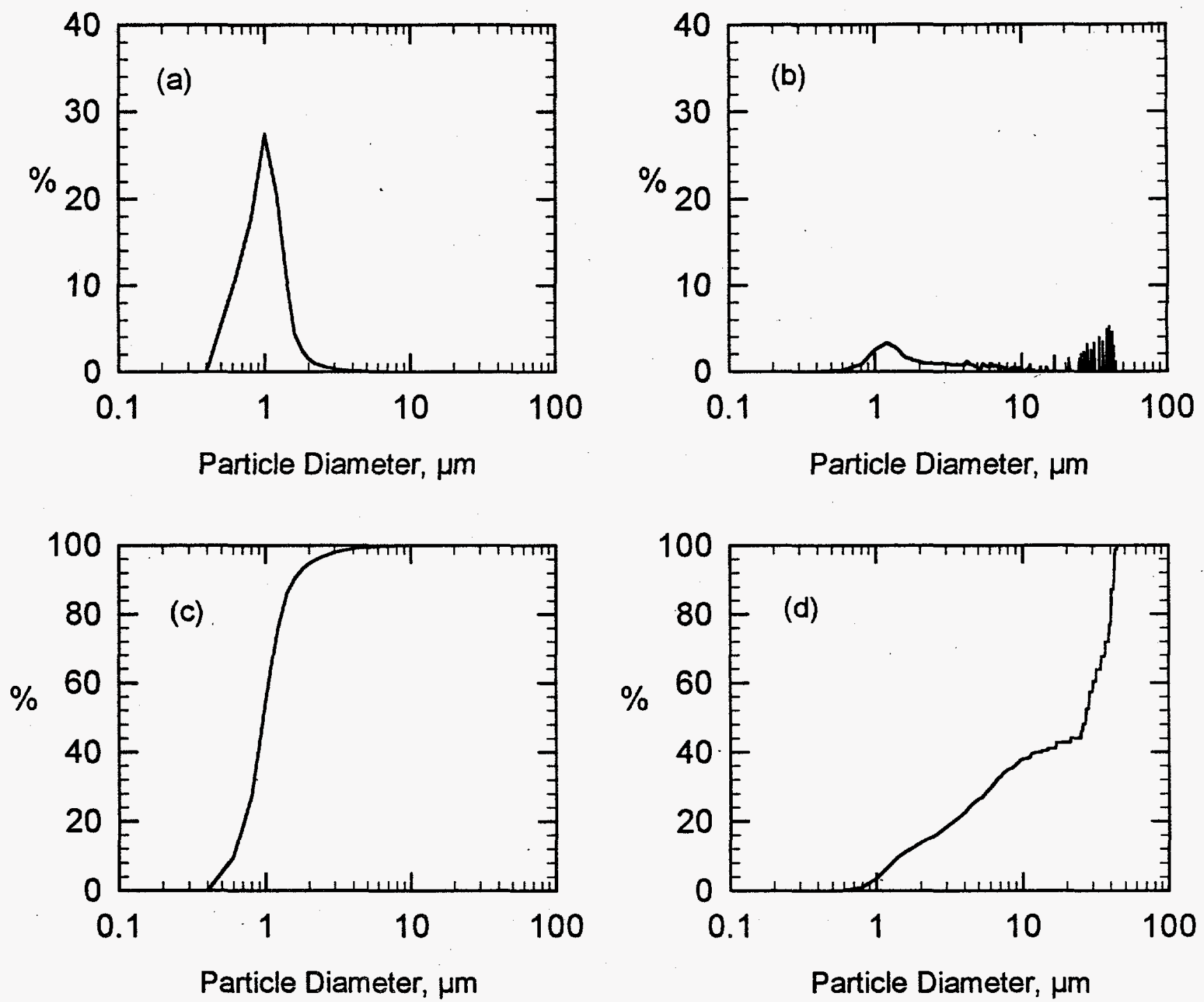

Figure D.3. Particle-Size Data for Treated S-104 Sludge: a) Probability-Number Density Graph, b) Probability-Volume Density Graph, c) Probability-Number Distribution Graph, and d) Probability-Volume Distribution Graph. 


\section{Appendix E}

Results from the Tank SY-103 Sludge

Washing and Caustic Leaching Test 


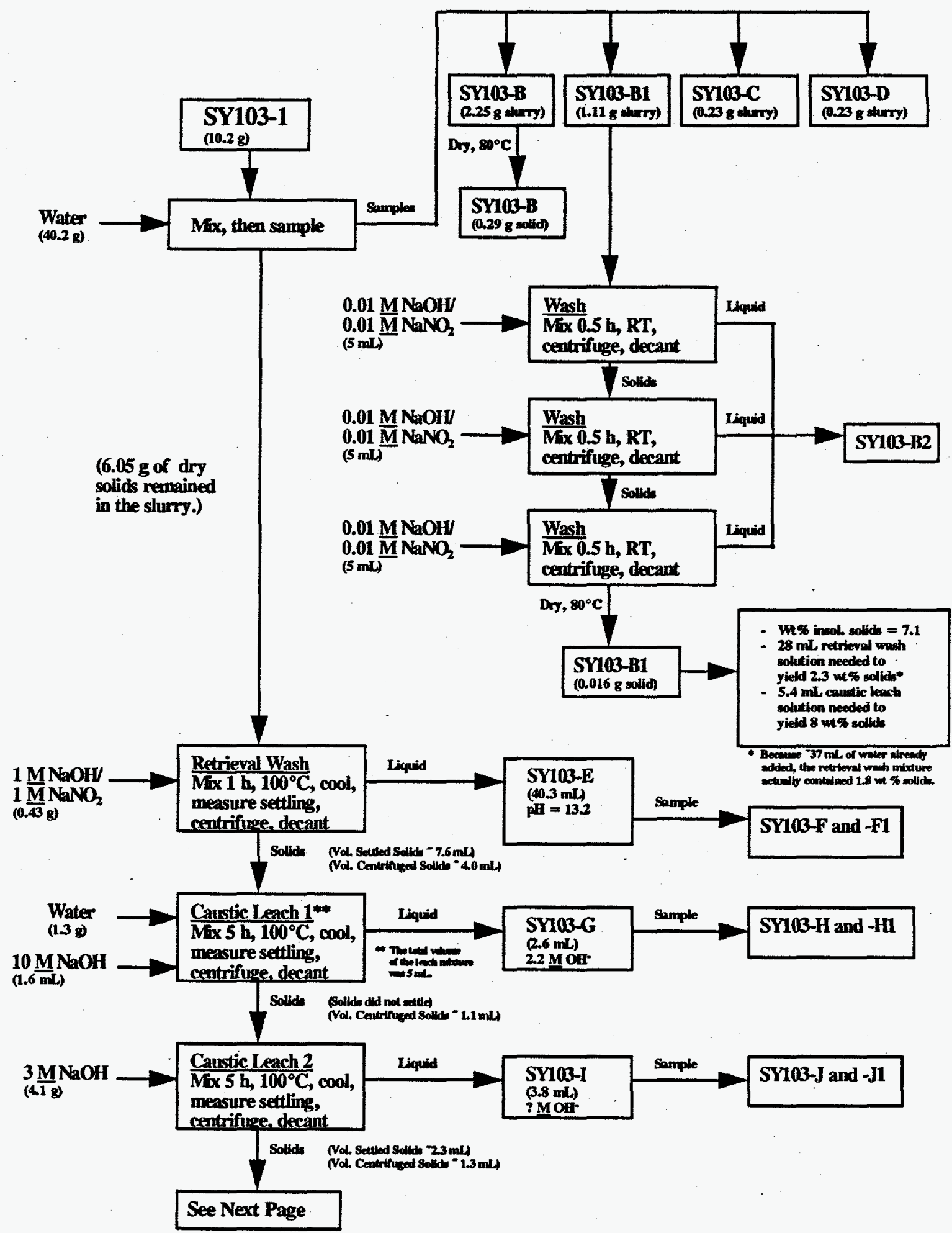

Figure E.1. Schematic of SY-103 Sludge Washing and Caustic Leaching Test

E.1 


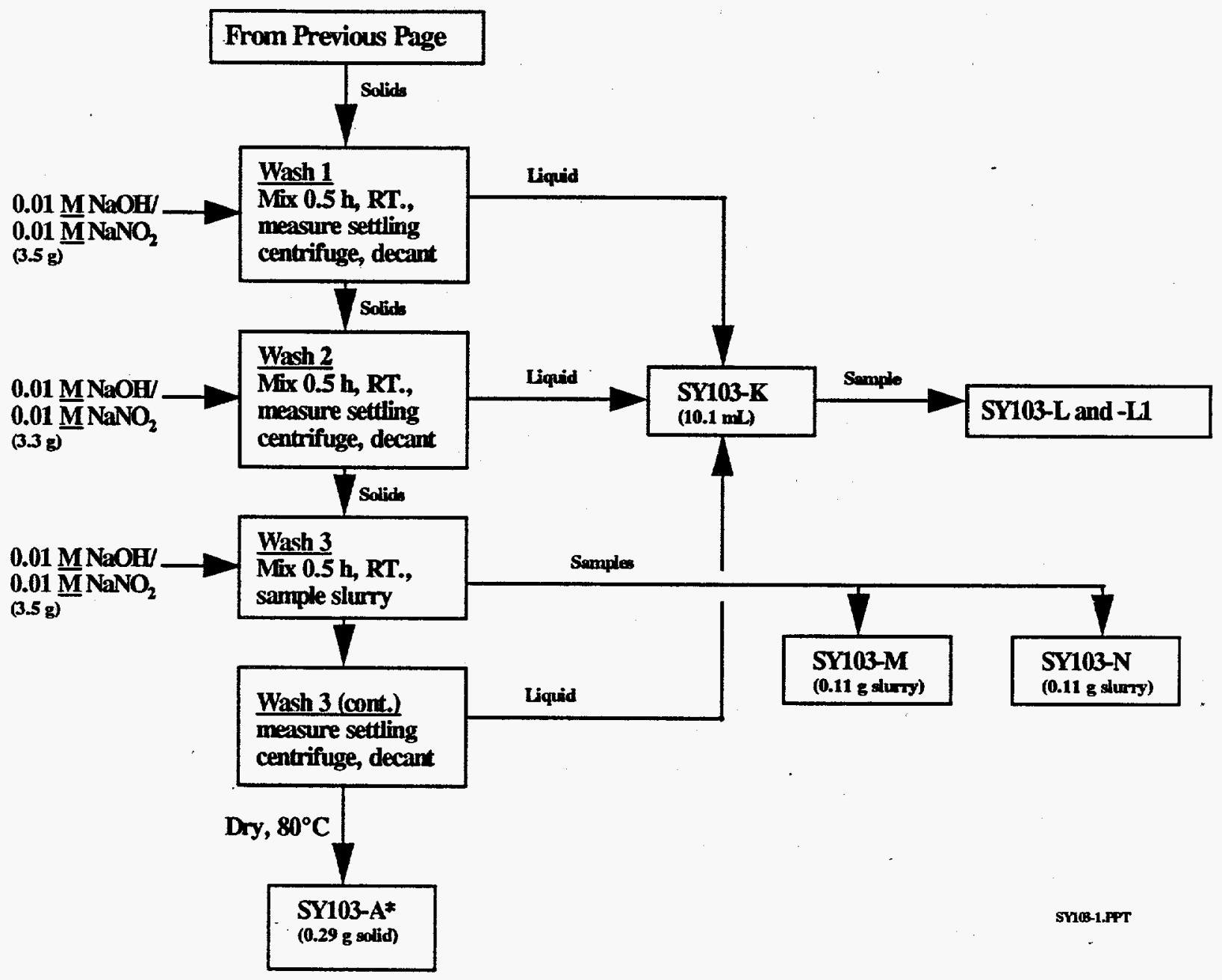

Figure E.1. (contd.) 
Table E.1. Concentrations of the Nonradioactive Sludge Components in the Various Process Solutions From the SY-103 Test

\begin{tabular}{|c|c|c|c|c|c|}
\hline \multirow[b]{2}{*}{ Component } & \multirow[b]{2}{*}{$\begin{array}{c}\text { Detection } \\
\text { Limit, } \mu \mathrm{g} / \mathrm{mL}\end{array}$} & \multicolumn{4}{|c|}{ Concentration, $\mu \mathrm{g} / \mathrm{mL}^{(0)}$} \\
\hline & & $\begin{array}{l}\text { Retrieval Solution } \\
\text { (E) }\end{array}$ & $\begin{array}{l}\text { First Caustic } \\
\text { Leach (G) }\end{array}$ & $\begin{array}{l}\text { Secoad Caustic } \\
\text { Leach (I) }\end{array}$ & Wash (K) \\
\hline Ag & 0.17 & 0 & 0 & 0 & 0 \\
\hline Al & 0.85 & 518.5 & 43350 & 15300 & 1615 \\
\hline As & 0.34 & 3.4 & 0 & 15.3 & 0 \\
\hline B & 0.34 & 11.05 & 76.5 & 1.7 & $\mathbf{0}$ \\
\hline Ba & 0.17 & 0 & 25.5 & 0 & 0 \\
\hline $\mathrm{Be}$ & 0.085 & $\mathbf{0}$ & 0 & 0 & 0 \\
\hline $\mathbf{B i}$ & 1.7 & 0 & 0 & 0 & 0 \\
\hline $\mathrm{Ca}$ & 0.85 & 10.2 & 1683 & 5.1 & 3.4 \\
\hline Cd & 0.17 & 0.255 & 0 & 0 & 0 \\
\hline $\mathrm{Ce}$ & 1.7 & 0 & 0 & 0 & 0 \\
\hline Co & 0.17 & $\mathbf{0}$ & 1249.5 & 0 & 0 \\
\hline $\mathrm{Cr}_{\mathrm{r}}$ & 0.34 & 85 & 739.5 & 646 & 136 \\
\hline $\mathrm{Cu}$ & 0.17 & 0 & 0 & 0 & $\mathbf{0}$ \\
\hline Dy & 0.34 & 0 & 0 & 0 & 0 \\
\hline Eu & 0.17 & 0 & 0 & 0 & 0 \\
\hline $\mathrm{Fe}$ & 0.17 & 0.85 & 2805 & 0.85 & 0.34 \\
\hline Gd & 3.4 & 0 & 0 & 0 & 0 \\
\hline $\mathbf{K}$ & 25.5 & 459 & $\mathbf{0}$ & 34 & $\mathbf{0}$ \\
\hline La & 0.51 & 0 & 0 & 0 & $\mathbf{0}$ \\
\hline $\overrightarrow{\mathbf{L i}}$ & 0.34 & 0 & 0 & 0.51 & 0 \\
\hline $\mathbf{M g}$ & 1.7 & 0 & 0 & 0 & 0 \\
\hline $\mathbf{M n}$ & 0.085 & - 0 & 0 & $\mathbf{0}$ & 0 \\
\hline Mo & 0.34 & 16.15 & 0 & o & 0 \\
\hline $\mathrm{Na}$ & 1.7 & 42500 & 163200 & 82450 & 9350 \\
\hline Nd & 0.51 & $\mathbf{0}$ & $\mathbf{0}$ & o & 0 \\
\hline $\mathbf{N i}$ & 0.51 & 5.78 & 459 & $\mathbf{0}$ & 0 \\
\hline $\mathbf{P}$ & 1.7 & 161.5 & 510 & 153 & 20.4 \\
\hline $\mathbf{P b}$ & 0.85 & 0 & 0 & 0 & 0 \\
\hline Pd & 2.55 & 0 & 0 & 0 & $\mathbf{0}$ \\
\hline $\mathbf{R h}$ & 1.7 & 0 & 0 & 0 & 0 \\
\hline $\mathbf{R u}$ & 1.7 & 2.55 & $\mathbf{0}$ & 0 & $\mathbf{0}$ \\
\hline $\mathbf{S b}$ & 0.85 & 0 & 0 & 0 & 0 \\
\hline $\mathrm{Se}$ & 1.7 & 0 & 0 & 2.55 & 0 \\
\hline Si & 0.85 & 7.65 & 5355 & 0 & 0 \\
\hline Sn & 17 & 0 & 0 & $\mathbf{0}$ & 0 \\
\hline Sr & 0.085 & $\mathbf{0}$ & 0 & 0 & 0 \\
\hline $\mathrm{Te}$ & 3.4 & 0 & 0 & 0 & 0 \\
\hline Th & 17 & 0 & 0 & 0 & 0 \\
\hline $\mathrm{Ti}$ & 0.085 & 0 & 0 & 0 & 0 \\
\hline $\mathrm{TI}$ & 8.5 & 0 & 0 & 25.5 & 0 \\
\hline $\mathrm{u}$ & 0.00425 & 5.321 & 13.94085 & 17.935 & 2.9665 \\
\hline $\mathrm{v}$ & 0.17 & 0.34 & 0 & 0.51 & 0 \\
\hline w & 1.7 & 26.35 & o & 5.95 & 0 \\
\hline $\mathbf{Y}$ & 0.17 & 0 & 0 & 0 & o \\
\hline $\mathbf{Z n}$ & 0.34 & 0 & 127.5 & 0.85 & 0.425 \\
\hline $\mathrm{Zr}$ & 0.17 & 0 & 0 & 0.51 & 0 \\
\hline $\mathrm{NO}_{3}^{-}$ & 500 & 22200 & 130 & 1910 & 170 \\
\hline $\mathrm{NO}_{2}^{-}$ & 500 & 13700 & 90 & 1200 & 350 \\
\hline $\mathrm{PO}_{4}{ }^{3-}$ & 20 & 1750 & 0 & 290 & 0 \\
\hline $\mathrm{SO}_{4}{ }^{2-}$ & 50 & 1240 & 0 & 110 & 0 \\
\hline $\mathbf{F}$ & (b) & (b) & (b) & (b) & (b) \\
\hline $\mathrm{Cl}^{-}$ & 250 & 1100 & (b) & (b) & (b) \\
\hline$B r^{-}$ & 250 & 0 & 0 & 0 & 0 \\
\hline
\end{tabular}

(a) Unless otherw iac indicated, zero values indicate the analyte was below the detection limit.

(b) Analyte could not be determined due to analytical difficulties.

(c) The detection limit was $50 \mu \mathrm{g} / \mathrm{mL}$ for nitrate, nitrite, phosphate, and sulfate for the leach and final wash steps; the detction limit for bromide was $25 \mu \mathrm{g} / \mathrm{mL}$ for the leach and wash steps. 
Table E.2. Concentrations of the Nonradioactive Sludge Components in the Leached Sludge From the SY-103 Test

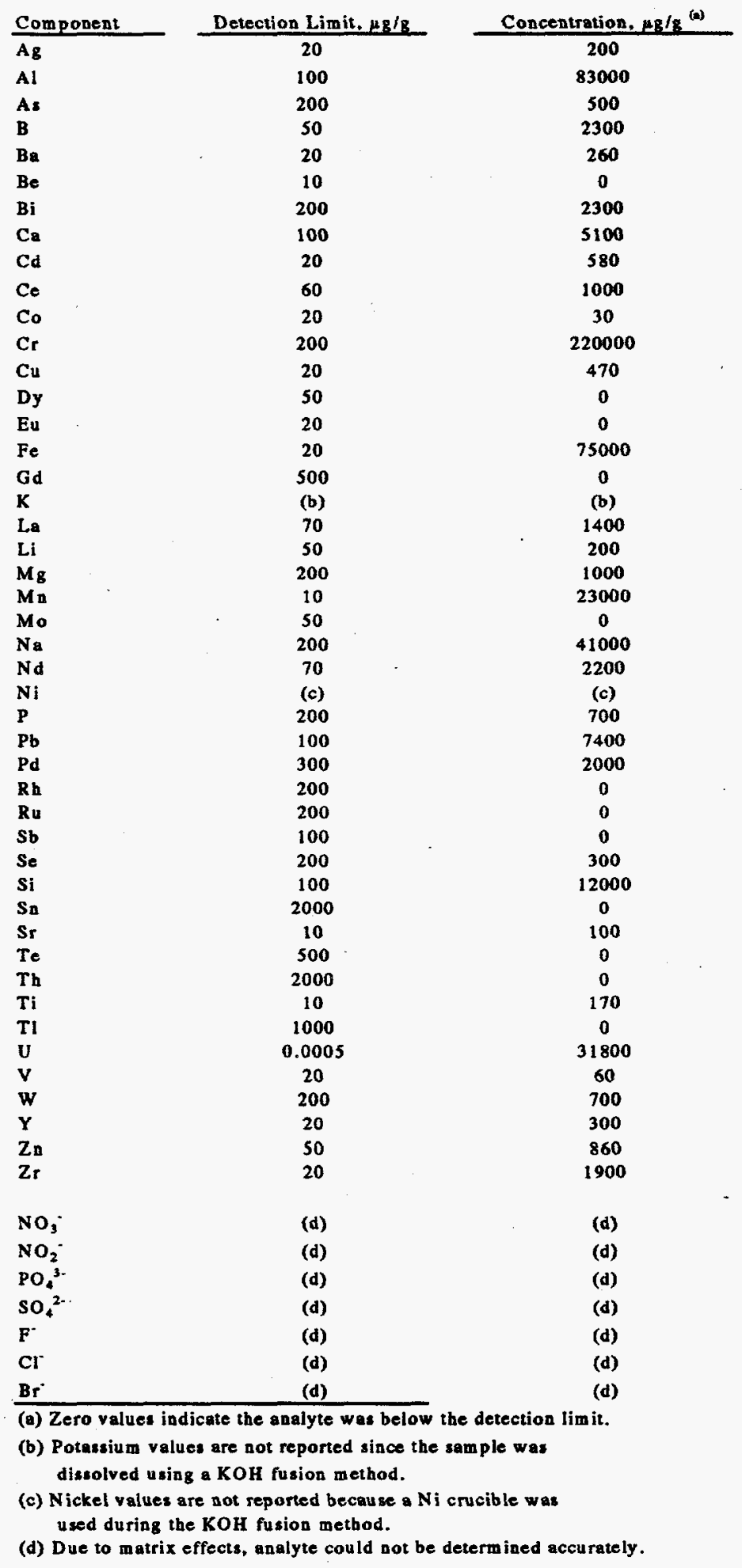

E.4 
Table E.3. Distribution of the Nonradioactive Sludge Components Between the Various Process Streams From the SY-103 Test

\begin{tabular}{|c|c|c|c|c|c|}
\hline \multirow[b]{2}{*}{ Component } & \multicolumn{5}{|c|}{ Amount of Component Found, $\%$} \\
\hline & $\begin{array}{c}\text { Retrieval } \\
\text { Solution (E) }\end{array}$ & $\begin{array}{l}\text { First Caustic } \\
\text { Leach (G) }\end{array}$ & $\begin{array}{l}\text { Second Canstic } \\
\text { Leach (I) }\end{array}$ & Wash (K) & Residue (A) \\
\hline $\mathbf{A g}$ & 0 & 0 & 0 & 0 & 100 \\
\hline Al & 9 & 48 & 25 & 7 & 10 \\
\hline As & 40 & $\mathbf{0}$ & 17 & $\mathbf{0}$ & 43 \\
\hline B & 34 & 15 & 0 & 0 & 51 \\
\hline $\mathbf{B a}$ & 0 & 46 & 0 & 0 & 54 \\
\hline Be & (a) & (a) & (a) & (a) & (a) \\
\hline Bi & $\mathbf{0}$ & $\mathbf{0}$ & $\mathbf{0}$ & $\mathbf{0}$ & 100 \\
\hline $\mathrm{Ca}$ & 6 & 69 & 0 & 1 & 24 \\
\hline Cd & 6 & 0 & o & o & 94. \\
\hline $\mathrm{Ce}$ & 0 & 0 & 0 & o & 100 \\
\hline Co & 0 & 100 & 0 & o & 0 \\
\hline $\mathrm{Cr}$ & 5 & 3 & 3 & 2 & 88. \\
\hline $\mathrm{Cu}$ & 0 & 0 & 0 & 0 & 100 \\
\hline Dy & (a) & (a) & (a) & (a) & (a) \\
\hline Eu & (a) & (a) & (a) & (a) & (a) \\
\hline $\mathrm{Fe}$ & 0 & 25 & 0 & 0 & 75 \\
\hline Gd & (a) & (a) & (a) & (a) & (a) \\
\hline $\mathbf{K}$ & (b) & (b) & (b) & (b) & (b) \\
\hline $\mathrm{La}$ & 0 & 0 & 0 & 0 & 100 \\
\hline $\mathbf{L i}$ & 0 & 0 & 3 & 0 & 97 \\
\hline Mg & $\mathbf{0}$ & $\mathbf{0}$ & 0 & 0 & 100 \\
\hline Mn & $\mathbf{0}$ & 0 & 0 & 0 & 100 \\
\hline Mo & 100 & 0 & 0 & 0 & 0 \\
\hline Na & (c) & (c) & (c) & (c) & (c) \\
\hline Nd & 0 & 0 & 0 & 0 & 100 \\
\hline $\mathrm{Ni}$ & (b) & (b) & (b) & (b) & (b) \\
\hline $\mathbf{P}$ & 74 & 15 & 7 & 2 & 2 \\
\hline Po & 0 & .0 & 0 & $\mathbf{0}$ & 100 \\
\hline Pd & 0 & 0 & 0 & $\mathbf{0}$ & 100 \\
\hline $\mathbf{R h}$ & (a) & (a) & (a) & (a) & (a) \\
\hline $\mathbf{R u}$ & 100 & 0 & 0 & 0 & 0 \\
\hline $\mathbf{S b}$ & (a) & (a) & (a) & (a) & (a) \\
\hline Se & 0 & 0 & 10 & 0 & 90 \\
\hline $\mathrm{Si}$ & 2 & 78 & 0 & 0 & 20 \\
\hline $\mathrm{Sn}$ & (a) & (a) & (a) & (a) & (a) \\
\hline $\mathrm{sr}$ & 0 & 0 & 0 & 0 & 100 \\
\hline $\mathrm{Te}$ & (a) & (a) & (a) & (a) & (a) \\
\hline Th & (a) & (a) & (a) & (a) & (a) \\
\hline $\mathrm{Ti}$ & 0 & 0 & 0 & 0 & 100 \\
\hline $\mathrm{T}$ & 0 & 0 & 100 & 0 & 0 \\
\hline $\mathbf{U}$ & 2 & 0 & 1 & 0 & 96 . \\
\hline $\mathrm{v}$ & 41 & 0 & 6 & 0 & 53 \\
\hline $\mathbf{w}$ & 82 & 0 & 2 & 0 & 16 \\
\hline $\mathbf{Y}$ & 0 & 0 & 0 & 0 & 100 \\
\hline $\mathrm{Zn}$ & 0 & 56 & 1 & 1 & 43 \\
\hline $\mathbf{Z r}$ & 0 & 0 & 0 & 0 & 100 \\
\hline $\mathrm{NO}_{3}^{-}$ & (d) & (d) & (d) & (d) & (d) \\
\hline $\mathrm{NO}_{2}^{-}$ & (d) & (d) & (d) & (d) & (d) \\
\hline $\mathrm{PO}_{4}{ }^{3-}$ & (d) & (d) & (d) & (d) & (d) \\
\hline $\mathrm{SO}_{4}^{2-}$ & (d) & (d) & (d) & (d) & (d) \\
\hline $\mathbf{F}$ & (d) & (d) & (d) & (d) & (d) \\
\hline $\mathrm{Cl}^{-}$ & (d) & (d) & (d) & (d) & (d) \\
\hline $\mathrm{Br}$ & (d) & (d) & (d) & (d) & (d) \\
\hline \multicolumn{6}{|c|}{ (a) Component was not detected. } \\
\hline \multicolumn{6}{|c|}{$\begin{array}{l}\text { (b) } \mathrm{K} \text { and Ni values could not be determined due to the KOH fusion procedure used } \\
\text { to prepare the leached sludge for analysis. }\end{array}$} \\
\hline $\begin{array}{l}\text { (c) Removal } \\
\text { cannot b }\end{array}$ & $\begin{array}{l}\text { from the sludg } \\
\text { nguished from }\end{array}$ & $\begin{array}{l}\text { Nano be reliably } \\
\text { Nadded in the }\end{array}$ & $\begin{array}{l}\text { *ed because the } N \\
\text { shing and leaching }\end{array}$ & he sludge & \\
\hline
\end{tabular}

E.5 
Table E.4. Mass Balance for Nonradioactive Sludge Components From the SY-103 Test

\begin{tabular}{|c|c|c|c|}
\hline \multirow[b]{2}{*}{ Component } & \multicolumn{2}{|c|}{ Concentration in Dried Sludge, g/g Sludge } & \multirow[b]{2}{*}{ Recovery, \% } \\
\hline & Direet Analysis & Summation Method & \\
\hline $\mathrm{Ag}$ & $1.00 \mathrm{E}-05$ & $9.72 \mathrm{E}-06$ & 97 \\
\hline A1 & $4.70 \mathrm{E}-02$ & $3.84 \mathrm{E}-02$ & 82 \\
\hline As & $1.00 \mathrm{E}-04$ & $5.65 \mathrm{E}-05$ & 57 \\
\hline B & $1.00 \mathrm{E}-03$ & $2.19 \mathrm{E}-04$ & 22 \\
\hline $\mathbf{B a}$ & $2.00 \mathrm{E}-05$ & $2.36 \mathrm{E}-05$ & 118 \\
\hline $\mathrm{Be}$ & $<3.00 \mathrm{E}-06$ & & \\
\hline Bi & $2.00 \mathrm{E}-04$ & $1.12 \mathrm{E}-04$ & 56 \\
\hline Ca & $4.00 \mathrm{E}-04$ & $1.05 E-03$ & 262 \\
\hline Cd & $4.00 \mathrm{E}-05$ & $2.99 \mathrm{E}-05$ & 75 \\
\hline $\mathrm{Ce}$ & $<6.00 \mathrm{E}-05$ & $4.86 \mathrm{E}-05$ & \\
\hline Co & $<7.00 \mathrm{E}-06$ & $5.38 \mathrm{E}-04$ & \\
\hline $\mathrm{Cr}$ & $1.30 \mathrm{E}-02$ & $1.22 \mathrm{E}-02$ & 94 \\
\hline $\mathrm{Cu}$ & $4.00 \mathrm{E}-05$ & $2.28 \mathrm{E}-05$ & 57 \\
\hline Dy & $<1.00 \mathrm{E}-05$ & & \\
\hline $\mathrm{Eu}$ & $<7.00 \mathrm{E}-06$ & & \\
\hline $\mathrm{Fe}$ & $4.10 \mathrm{E}-03$ & $4.86 \mathrm{E}-03$ & 118 \\
\hline Gd & $<1.00 \mathrm{E}-04$ & & \\
\hline $\mathbf{K}$ & (b) & (b) & (b) \\
\hline $\mathbf{L a}$ & $6.00 \mathrm{E}-05$ & $6.80 \mathrm{E}-05$ & 113 \\
\hline $\mathbf{L i}$ & $<1.00 \mathrm{E}-05$ & $1.00 \mathrm{E}-05$ & \\
\hline $\mathbf{M g}$ & $8.00 \mathrm{E}-05$ & $4.86 \mathrm{E}-05$ & 61 \\
\hline $\mathbf{M n}$ & $1.40 \mathrm{E}-03$ & $1.12 \mathrm{E}-03$ & 80 \\
\hline Mo & $9.00 \mathrm{E}-05$ & $1.08 \mathrm{E}-04$ & 120 \\
\hline $\mathbf{N a}$ & $2.80 \mathrm{E}-01$ & & \\
\hline Nd & $1.00 \mathrm{E}-04$ & $1.07 \mathrm{E}-04$ & 107 \\
\hline $\mathbf{N i}$ & (b) & (b) & (b) \\
\hline $\mathbf{P}$ & $7.80 \mathrm{E}-03$ & $1.46 \mathrm{E}-03$ & 19 \\
\hline $\mathbf{P b}$ & $4.30 \mathrm{E}-04$ & $3.60 \mathrm{E}-04$ & 84 \\
\hline Pd & $<1.00 \mathrm{E}-04$ & $9.72 \mathrm{E}-05$ & \\
\hline $\mathbf{R h}$ & $<7.00 \mathrm{E}-05$ & & \\
\hline $\mathbf{R u}$ & $<7.00 \mathrm{E}-05$ & $1.70 \mathrm{E}-05$ & \\
\hline Sb & $<3.00 \mathrm{E}-05$ & & \\
\hline Se & $<5.00 \mathrm{E}-05$ & $1.62 \mathrm{E}-05$ & \\
\hline Si & $2.00 \mathrm{E}-03$ & $2.93 \mathrm{E}-03$ & 147 \\
\hline Sn & $<7.00 \mathrm{E}-04$ & & \\
\hline Sr & $8.00 \mathrm{E}-06$ & $4.86 \mathrm{E}-06$ & 61 \\
\hline Te & $<1.00 \mathrm{E}-04$ & & \\
\hline Th & $<6.00 \mathrm{E}-04$ & & \\
\hline $\mathbf{T i}$ & $1.00 \mathrm{E}-05$ & $8.26 \mathrm{E}-06$ & 83 \\
\hline T1 & $<3.00 \mathrm{E}-04$ & $1.60 E-05$ & \\
\hline $\mathbf{U}$ & $1.61 \mathrm{E}-03$ & $1.60 \mathrm{E}-03$ & 100 \\
\hline $\mathbf{v}$ & $9.00 \mathrm{E}-06$ & $5.50 \mathrm{E}-06$ & 61 \\
\hline w & $2.00 \mathrm{E}-04$ & $2.13 \mathrm{E}-04$ & 107 \\
\hline $\mathbf{Y}$ & $2.00 \mathrm{E}-05$ & $1.46 \mathrm{E}-05$ & 73 \\
\hline $\mathbf{Z n}$ & $7.00 \mathrm{E}-05$ & $9.78 \mathrm{E}-05$ & 140 \\
\hline $\mathbf{Z r}$ & $1.00 \mathrm{E}-04$ & $9.26 \mathrm{E}-05$ & 93 \\
\hline $\mathrm{NO}_{3}^{-}$ & (c) & (c) & (c) \\
\hline $\mathrm{NO}_{2}^{-}$ & (c) & (c) & (c) \\
\hline $\mathrm{PO}_{4}^{3-}$ & (c) & (c) & (c) \\
\hline $\mathrm{SO}_{4}^{2-}$ & (c) & (c) & (c) \\
\hline $\mathbf{F}^{-}$ & (c) & (c) & (c) \\
\hline $\mathrm{Cl}^{-}$ & (c) & (c) & (c) \\
\hline$B r^{\circ}$ & (c) & (c) & (c) \\
\hline
\end{tabular}

E.6 
Table E.5. Concentrations of the Radioactive Sludge Components in the Various Process Streams From the SY-103 Test

\begin{tabular}{|c|c|c|c|c|}
\hline \multirow[b]{2}{*}{ Component } & \multicolumn{4}{|c|}{ Concentration, $\mu \mathrm{Ci} / \mathrm{mL}$} \\
\hline & $\begin{array}{c}\text { Retrieval } \\
\text { Solution (E) }\end{array}$ & $\begin{array}{l}\text { First Caustic } \\
\text { Leach }(G)\end{array}$ & $\begin{array}{c}\text { Second Caustic } \\
\text { Leach (I) }\end{array}$ & Wash (K) \\
\hline Total Alpha & $1.78 \mathrm{E}-03$ & 5.59E-04 & 1.79E-04 & $2.83 \mathrm{E}-05$ \\
\hline${ }^{239,240} \mathrm{Pu}$ & $1.33 \mathrm{E}-03$ & 5.59E-04 & $6.94 E-05$ & $1.32 \mathrm{E}-05$ \\
\hline${ }^{241} \mathrm{Am}+{ }^{238} \mathrm{Pu}$ & 4.45E-04 & $<3.57 \mathrm{E}-04$ & $1.09 \mathrm{E}-04$ & $1.51 \mathrm{E}-05$ \\
\hline${ }^{241} \operatorname{Am}(\gamma)$ & $<1.70 \mathrm{E}-02$ & $<1.25 \mathrm{E}-02$ & $<1.70 \mathrm{E}-03$ & $<5.10 \mathrm{E}-04$ \\
\hline${ }^{137} \mathrm{Cs}$ & $5.73 E+01$ & $1.55 \mathrm{E}+01$ & $5.33 E+\infty 0$ & $5.73 \mathrm{E}-01$ \\
\hline${ }^{90} \mathrm{Sr}$ & 4.35E-01 & $1.67 \mathrm{E}-02$ & $2.36 \mathrm{E}-02$ & $3.30 \mathrm{E}-03$ \\
\hline \multirow[t]{2}{*}{${ }^{99} \mathrm{Tc}$} & $1.72 \mathrm{E}-02$ & $6.41 E-03$ & $5.26 \mathrm{E}-03$ & $9.69 \mathrm{E}-04$ \\
\hline & \multicolumn{3}{|c|}{ Concentration, $\mu \mathrm{Ci} / \mathrm{g}$} & \\
\hline Component & & Residue & & \\
\hline Total Alpha & & $2.75 \mathrm{E}+01$ & & \\
\hline${ }^{239,240} \mathrm{Pu}$ & & $<3.00 \mathrm{E}-01$ & & \\
\hline${ }^{241} \mathrm{Am}+{ }^{238} \mathrm{Pu}$ & & $2.75 \mathrm{E}+01$ & & \\
\hline${ }^{241} \mathrm{Am}(\gamma)$ & & $2.49 \mathrm{E}+01$ & & \\
\hline${ }^{137} \mathrm{Cs}$ & & $1.91 \mathrm{E}+01$ & & \\
\hline${ }^{90} \mathrm{Sr}$ & & $1.48 \mathrm{E}+03$ & & \\
\hline${ }^{99} \mathrm{Tc}$ & & $4.42 \mathrm{E}-01$ & & \\
\hline
\end{tabular}

E.7 
Table E.6. Distribution of the Radioactive Sludge Components Between the Various Process Streams From the SY-103 Test

Amount of Component Found, \%

\begin{tabular}{|c|c|c|c|c|c|}
\hline Component & $\begin{array}{c}\text { Retrieval } \\
\text { Solution (E) }\end{array}$ & $\begin{array}{c}\text { First Caustic } \\
\text { Leach }(G)\end{array}$ & $\begin{array}{c}\text { Second Caustic } \\
\text { Leach (I) }\end{array}$ & Wash (K) & Residue (A) \\
\hline Total Alpha & 1 & 0 & 0 & 0 & 99 \\
\hline${ }^{239,240} \mathrm{Pu}$ & 97 & 3 & 0 & $\mathbf{0}$ & 0 \\
\hline${ }^{241} \mathrm{Am}+{ }^{238} \mathrm{Pu}$ & 0 & 0 & 0 & 0 & 100 \\
\hline${ }^{241} \mathrm{Am}(\gamma)$ & 0 & 0 & 0 & 0 & 100 \\
\hline${ }^{137} \mathrm{Cs}$ & 97 & 2 & 1 & 0 & 0 \\
\hline${ }^{90} \mathrm{Sr}$ & 4 & 0 & 0 & 0 & 96 \\
\hline${ }^{99} \mathrm{Tc}$ & 80 & 2 & 2 & 1 & 15 \\
\hline
\end{tabular}

Table E.7. Mass Balance for Radioactive Sludge Components From the SY-103 Test

\begin{tabular}{|c|c|c|c|}
\hline \multirow[b]{2}{*}{ Component } & \multicolumn{2}{|c|}{ Concentration in Dried Sludge, $\mu \mathrm{Ci} / \mathrm{g}$} & \multirow[b]{2}{*}{ Recovery, \% } \\
\hline & Direct Analysis & Summation Method & \\
\hline Total Alpha & $1.47 \mathrm{E}+00$ & $1.35 \mathrm{E}+00$ & 92 \\
\hline${ }^{239,240} \mathrm{Pu}$ & $<4.00 \mathrm{E}-03$ & $9.19 \mathrm{E}-03$ & \\
\hline${ }^{241} \mathrm{Am}+{ }^{238} \mathrm{Pu}$ & $1.47 \mathrm{E}+\infty$ & $1.34 \mathrm{E}+\infty 0$ & 91 \\
\hline${ }^{241} \operatorname{Am}(\gamma)$ & $1.31 \mathrm{E}+00$ & $1.21 \mathrm{E}+\infty$ & 92 \\
\hline${ }^{137} \mathrm{Cs}$ & $3.61 \mathrm{E}+02$ & $3.93 \mathrm{E}+02$ & 109 \\
\hline${ }^{90} \mathrm{Sr}$ & $8.30 \mathrm{E}+01$ & $7.48 \mathrm{E}+01$ & 90 \\
\hline${ }^{99} \mathrm{Tc}$ & $3.53 \mathrm{E}-01$ & $1.44 \mathrm{E}-01$ & 41 \\
\hline
\end{tabular}



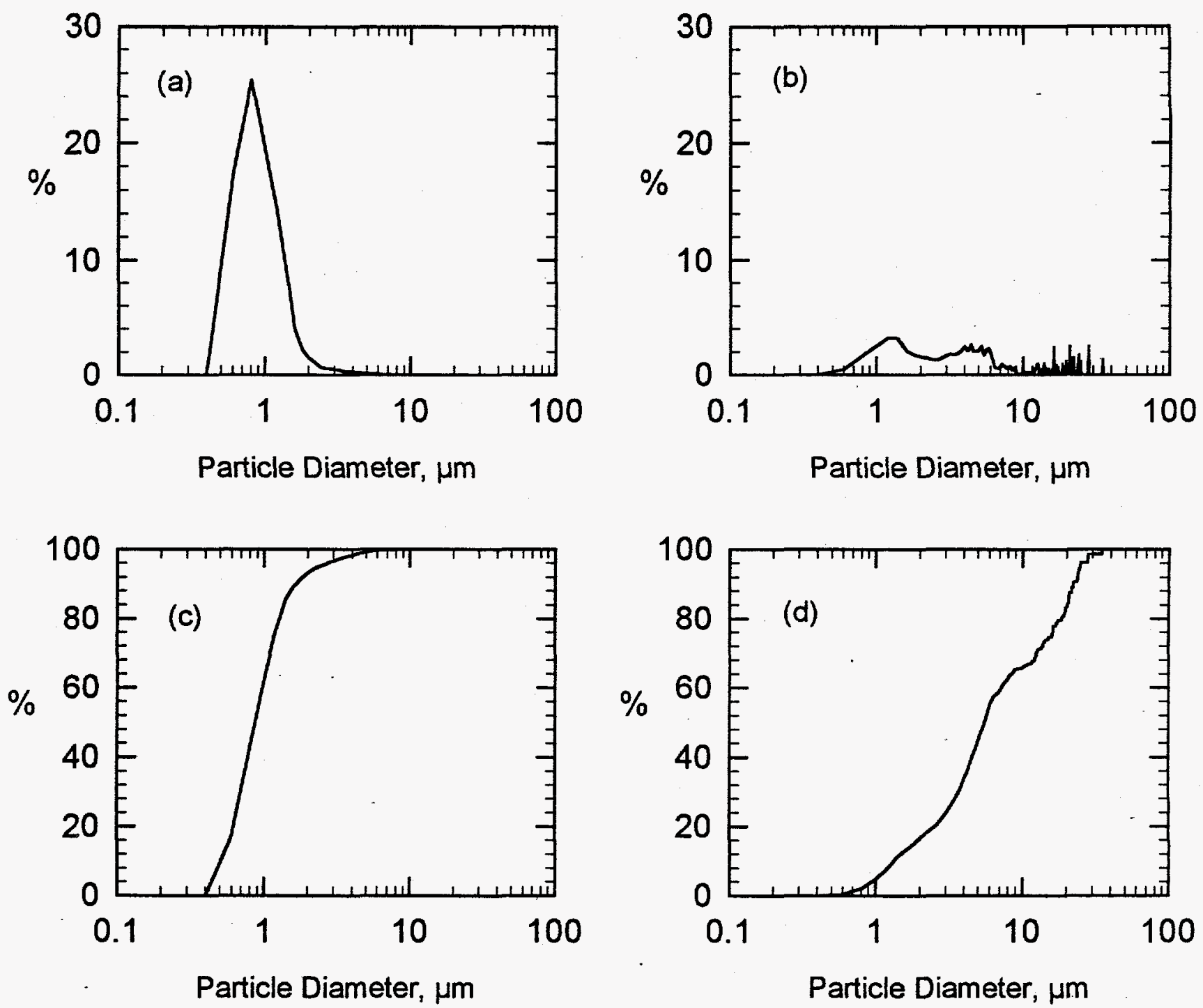

SY103-C.SPW

Figure E.2. Particle Size-Data for Untreated SY-103 Sludge: a) Probability-Number Density Graph, b) Probability-Volume Density Graph, c) Probability-Number Distribution Graph, and d) Probability-Volume Distribution Graph. 

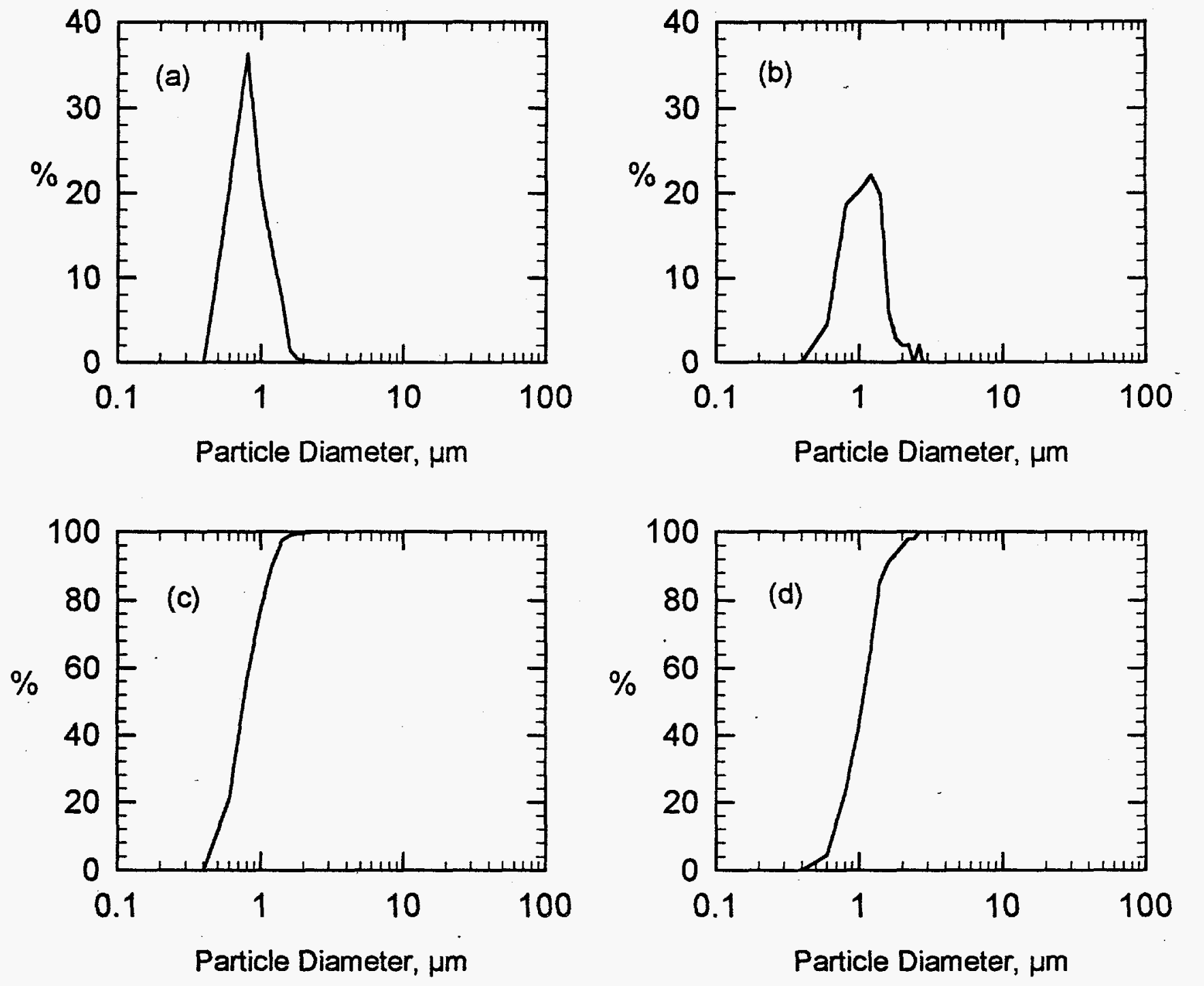

SY103-M.SPW

Figure E.3. Particle-Size Data for Treated SY-103 Sludge: a) Probability-Number Density Graph, b) Probability-Volume Density Graph, c) Probability-Number Distribution Graph, and d) Probability-Volume Distribution Graph. 


\section{Appendix F}

Results from the Tank T-104 Sludge

Washing and Caustic Leaching Test 


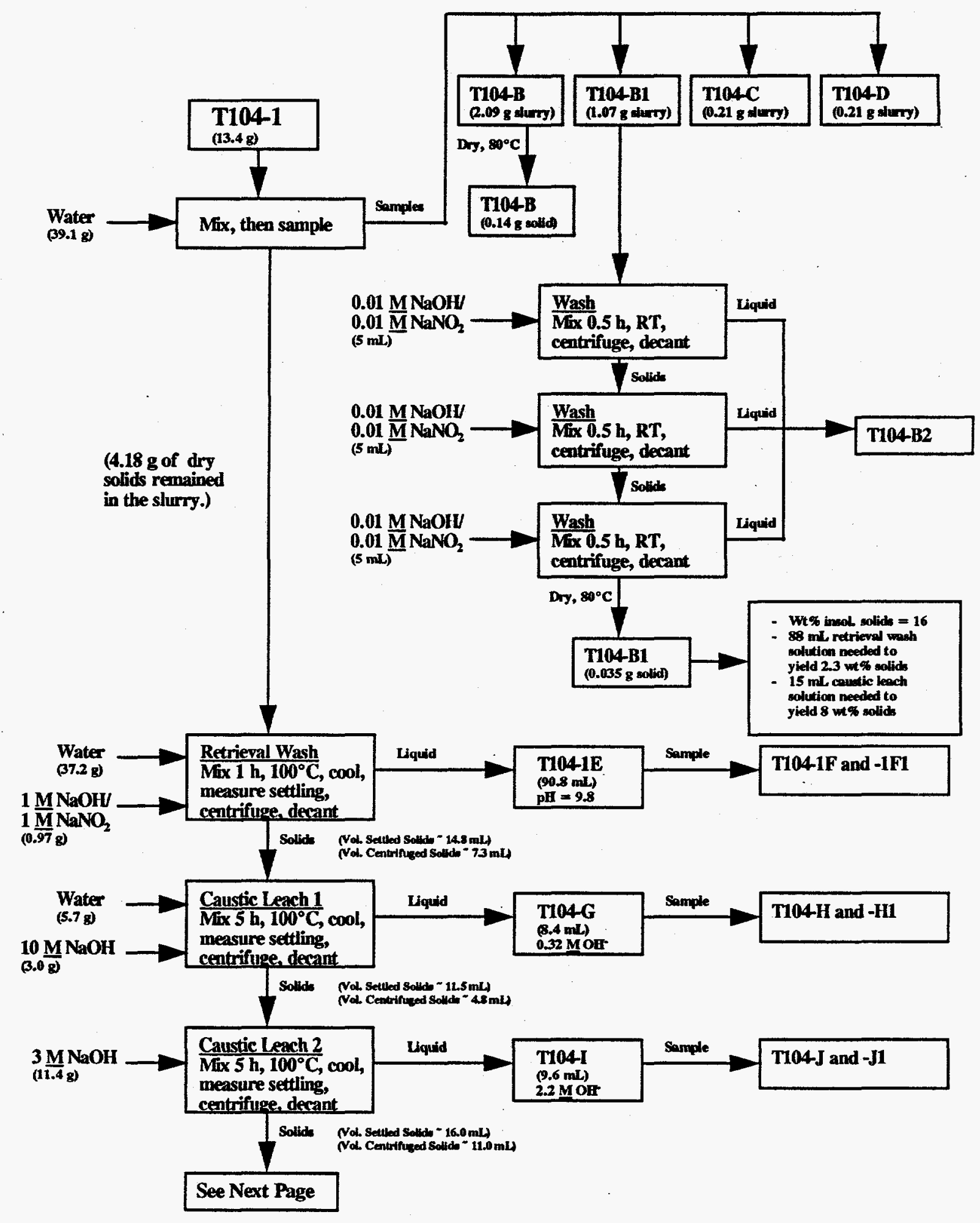

Figure F.1. Schematic of T-104 Sludge Washing and Caustic Leaching Test

F.1 


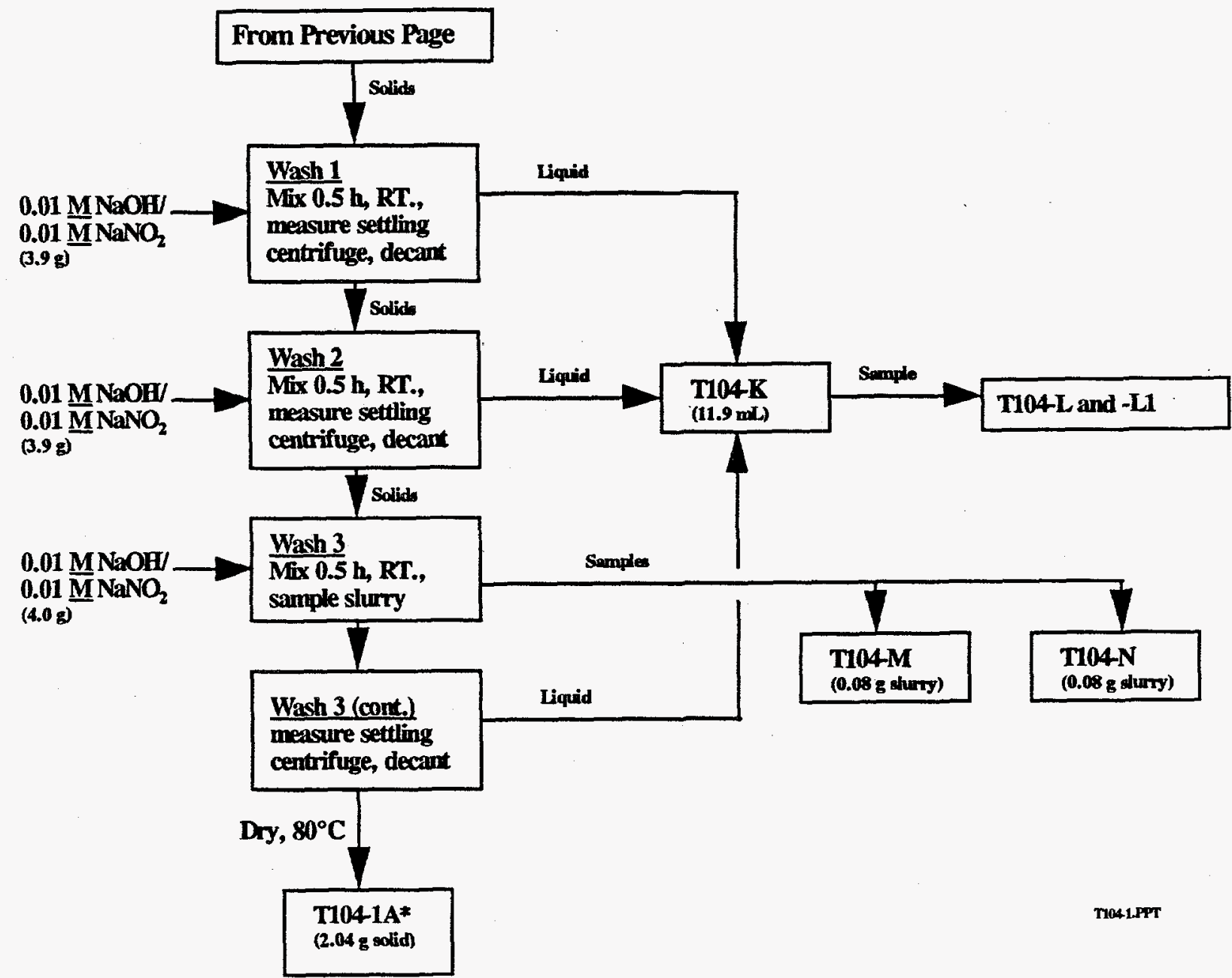

Figure 2.6. (contd.) 
Table F.1. Concentrations of the Nonradioactive Sludge Components in the Various Process Solutions From the T-104 Test

\begin{tabular}{|c|c|c|c|c|c|}
\hline \multirow[b]{2}{*}{ Component } & \multirow[b]{2}{*}{$\begin{array}{c}\text { Defection } \\
\text { Limit, } \mu g / m L \\
\end{array}$} & \multicolumn{4}{|c|}{ Concentration, $\mu \mathrm{g} / \mathrm{mL}^{(\omega)}$} \\
\hline & & $\begin{array}{l}\text { Retrieval Solution } \\
\text { (E) } \\
\end{array}$ & $\begin{array}{c}\text { First Caustic } \\
\text { Leach (O) } \\
\end{array}$ & $\begin{array}{c}\text { Second Caustic } \\
\text { Leach (1) }\end{array}$ & Wash (X) \\
\hline Ag & 0.17 & $\mathbf{0}$ & $\mathbf{0}$ & 0 & 0 \\
\hline Al & 0.85 & 24.65 & 5015 & 4845 & 1615 \\
\hline $\begin{array}{l}\text { As } \\
\text { B }\end{array}$ & $\begin{array}{c}1.7 \\
0.34\end{array}$ & $\begin{array}{c}0 \\
0.425\end{array}$ & $\begin{array}{c}8.5 \\
0.765\end{array}$ & $\begin{array}{c}8.5 \\
0\end{array}$ & $\begin{array}{c}3.4 \\
0\end{array}$ \\
\hline Ba & 0.17 & 0 & 0 & 0 & 0 \\
\hline $\mathrm{Be}$ & 0.085 & $\mathbf{0}$ & $\mathbf{0}$ & $\mathbf{0}$ & $\mathbf{0}$ \\
\hline $\mathbf{B i}$ & 1.7 & 0 & 2.55 & 18.7 & 5.95 \\
\hline $\mathrm{Ca}$ & 0.85 & 12.75 & 5.95 & 5.1 & 7.65 \\
\hline Cd & 0.17 & 0 & 0 & $\mathbf{0}$ & 0 \\
\hline $\mathrm{Ce}$ & 1.7 & 0 & 0 & $\mathbf{0}$ & $\mathbf{0}$ \\
\hline Co & 0.17 & 0 & 0 & $\mathbf{0}$ & 0 \\
\hline $\mathbf{C r}$ & 0.34 & 24.65 & 56.1 & 47.6 & 23.8 \\
\hline $\mathrm{Cu}$ & 0.17 & 0 & 0 & 0 & 0 \\
\hline Dy & 0.34 & 0 & 0 & 0 & 0 \\
\hline $\mathrm{Eu}$ & 0.17 & 0 & 0 & 0 & 0 \\
\hline $\mathrm{Fe}$ & 0.17 & 0.85 & 0.51 & 2.38 & 0.68 \\
\hline Gd & 3.4 & 0 & 0 & 0 & 0 \\
\hline $\mathbf{K}$ & 25.5 & 0 & 0 & 0 & 0 \\
\hline La & 0.51 & 0 & 0 & 0 & 0 \\
\hline $\mathbf{L i}$ & 0.34 & 0 & 0 & 0 & 0 \\
\hline Mg & 1.7 & 0 & 0 & 0 & 0 \\
\hline Mn & 0.085 & 0 & 0 & 0 & 0 \\
\hline Mo & 0.34 & 0 & 0 & 0 & 0 \\
\hline $\mathrm{Na}$ & 1.7 & 6205 & 24650 & 52700 & 34850 \\
\hline Nd & 0.51 & 0 & 0 & 0 & 0 \\
\hline $\mathrm{Ni}$ & 0.51 & 5.865 & 0 & 0 & 2.55 \\
\hline $\mathbf{P}$ & 1.7 & 833 & 2975 & 850 & 4080 \\
\hline $\mathbf{P b}$ & 0.85 & 0 & 0 & 0 & 0 \\
\hline Pd & 2.55 & 0 & 0 & 0 & 0 \\
\hline Rh & 1.7 & 0 & o & 0 & 0 \\
\hline $\mathbf{R u}$ & 1.7 & 0 & 0 & 0 & 0 \\
\hline Sb & 0.85 & 0 & 0 & 0 & 0 \\
\hline Se & 1.7 & 0 & 0 & 0 & 0 \\
\hline $\mathbf{S i}$ & 0.85 & 0 & 0 & 45.05 & 22.95 \\
\hline Sn & 17 & 0 & 0 & 0 & 0 \\
\hline Sr & 0.085 & 0 & 0 & 0 & 0 \\
\hline Te & 3.4 & 0 & 0 & 0 & 0 \\
\hline Th & 17 & 0 & 0 & 0 & 0 \\
\hline $\mathrm{Ti}$ & 0.085 & 0 & 0 & 0 & 0 \\
\hline$\pi$ & 8.5 & 0 & 0 & 0 & 0 \\
\hline $\mathbf{U}$ & 0.00255 & 1.258 & 18.19 & 96.05 & 28.9 \\
\hline v & 0.17 & 0 & 0 & 0 & 0 \\
\hline$w$ & 1.7 & 0 & 0 & 0 & 0 \\
\hline $\mathbf{Y}$ & 0.17 & 0 & 0 & 0 & 0 \\
\hline $\mathrm{Zn}$ & 0.34 & 5.865 & 0.51 & 3.485 & 3.485 \\
\hline $\mathbf{Z r}$ & 0.17 & 0 & 0 & 0.34 & 0 \\
\hline $\mathrm{NO}_{3}^{-}$ & 250 & 8400 & 4100 & 1000 & 260 \\
\hline $\mathrm{NO}_{2}^{-}$ & 100 & 1100 & 500 & 140 & 8800 \\
\hline $\mathrm{PO}_{4}{ }^{3}$ & 100 & 2600 & 9000 & 3100 & 12400 \\
\hline $\mathrm{SO}_{4}^{2-}$ & 100 & 500 & 500 & 100 & 30 \\
\hline $\mathbf{F}$ & 50 & 630 & 3000 & 80 & 1480 \\
\hline $\mathbf{C r}^{-}$ & 50 & 120 & 120 & $<25$ & 15 \\
\hline $\mathrm{Br}$ & 50 & $<50$ & $<50$ & $<25$ & $<25$ \\
\hline
\end{tabular}

(a) Unless otherwise indicated, zero values indicate the analyte was below the detection limit. 
Table F.2. Concentrations of the Nonradioactive Sludge Components in the Leached Sludge From the T-104 Test

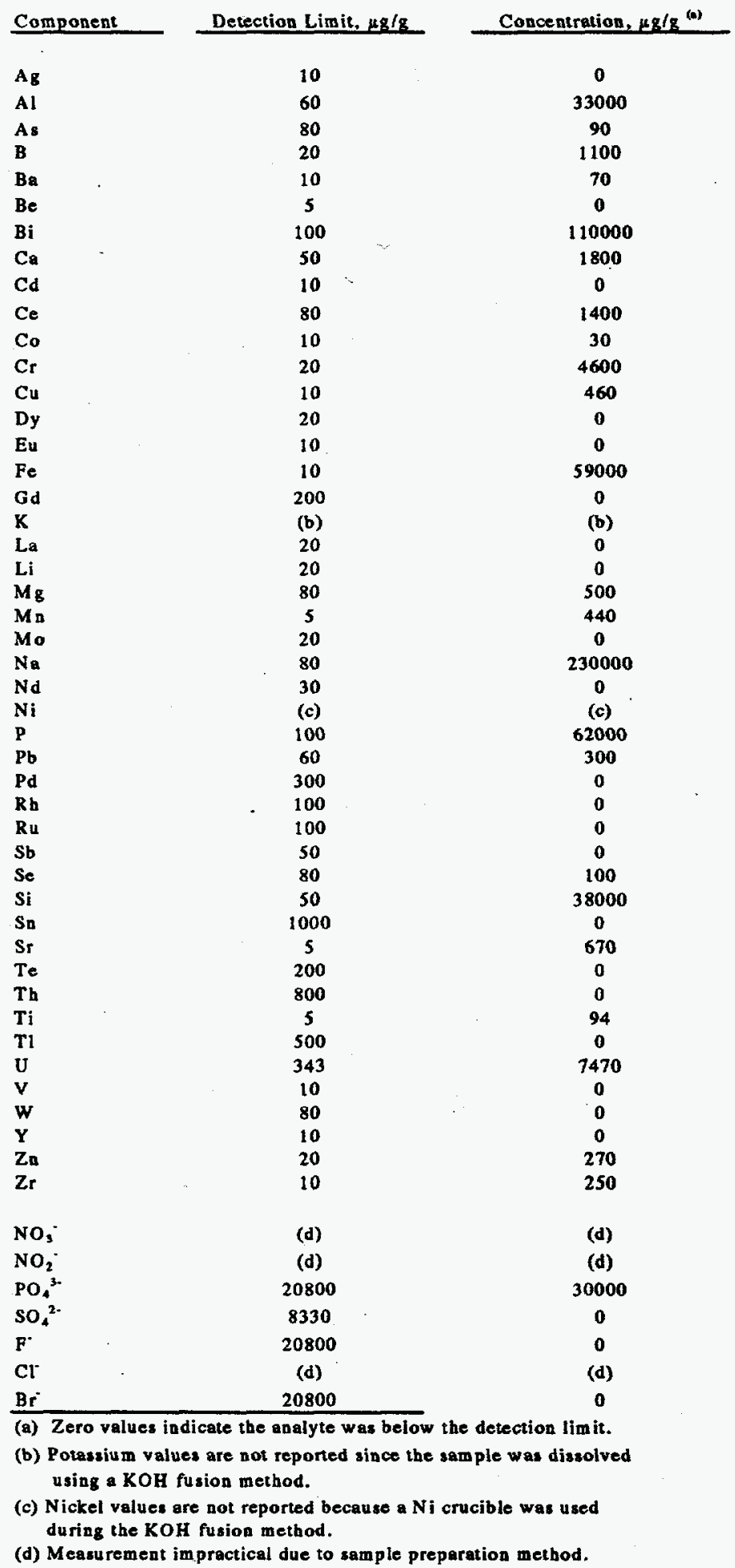

F.4 
Table F.3. Distribution of the Nonradioactive Sludge Components Between the Various Process Streams From the T-104 Test

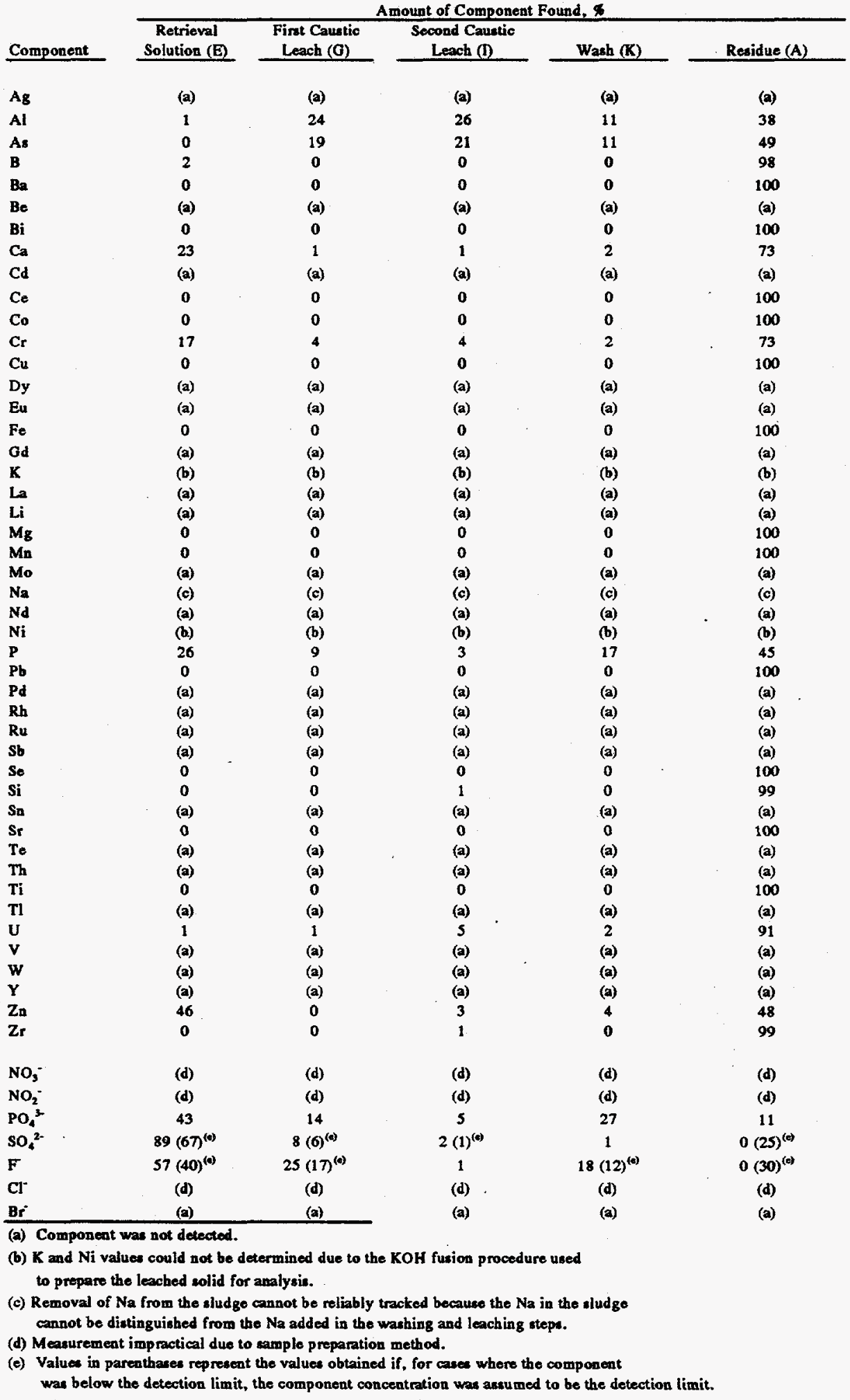


Table F.4. Mass Balance for Nonradioactive Sludge Components From the T-104 Test

\begin{tabular}{|c|c|c|c|}
\hline \multirow[b]{2}{*}{ Component } & \multicolumn{2}{|c|}{ Concentration in Dried Sludge, g/g Sludge } & \multirow[b]{2}{*}{ Recovery, } \\
\hline & Direct Analysis & Summation Method & \\
\hline $\mathrm{Ag}$ & $<2.00 \mathrm{E}-05$ & & \\
\hline Al & 4.70E-02 & $4.29 \mathrm{E}-02$ & -91 \\
\hline As & $<1.00 \mathrm{E}-04$ & $9.12 \mathrm{E}-05$ & \\
\hline B & 2.20E-03 & $5.58 \mathrm{E}-04$ & 25 \\
\hline $\mathbf{B a}$ & $<2.00 \mathrm{E}-05$ & $3.48 \mathrm{E}-05$ & \\
\hline $\mathrm{Be}$ & $<8.00 \mathrm{E}-06$ & & \\
\hline Bi & $5.20 \mathrm{E}-02$ & $5.48 \mathrm{E}-02$ & 105 \\
\hline $\mathbf{C a}$ & $1.30 \mathrm{E}-03$ & $1.22 \mathrm{E}-03$ & 94 \\
\hline Cd & $<2.00 \mathrm{E}-05$ & & \\
\hline $\mathrm{Ce}$ & $4.00 \mathrm{E}-04$ & $6.96 E-04$ & 174 \\
\hline Co & $3.00 \mathrm{E}-05$ & $1.49 \mathrm{E}-05$ & 50 \\
\hline $\mathrm{Cr}$ & $3.10 \mathrm{E}-03$ & $3.12 \mathrm{E}-03$ & 101 \\
\hline $\mathrm{Cu}$ & $7.00 \mathrm{E}-05$ & $2.29 \mathrm{E}-04$ & 327 \\
\hline Dy & $<3.00 \mathrm{E}-05$ & & \\
\hline $\mathbf{E u}$ & $<2.00 \mathrm{E}-05$ & & \\
\hline $\mathbf{F e}$ & $2.80 \mathrm{E}-02$ & $2.94 \mathrm{E}-02$ & 105 \\
\hline Gd & $<3.00 \mathrm{E}-04$ & & \\
\hline $\mathbf{K}$ & (b) & (b) & (b) \\
\hline La & $<5.00 \mathrm{E}-05$ & & \\
\hline $\mathbf{L i}$ & $<3.00 \mathrm{E}-05$ & & \\
\hline $\mathbf{M g}$ & 3.00E-04 & $2.49 \mathrm{E}-04$ & 83 \\
\hline $\mathrm{Mn}$ & $3.60 \mathrm{E}-04$ & $2.19 \mathrm{E}-04$ & 61 \\
\hline Mo & $<3.00 \mathrm{E}-05$ & & \\
\hline $\mathrm{Na}_{\mathbf{a}}$ & $1.90 \mathrm{E}-01$ & & \\
\hline Nd & $<5.00 \mathrm{E}-05$ & & \\
\hline $\mathbf{N i}$ & (b) & (b) & (b) \\
\hline $\mathbf{P}$ & $6.90 \mathrm{E}-02$ & $6.87 \mathrm{E}-02$ & 100 \\
\hline $\mathbf{P b}$ & $2.00 \mathrm{E}-04$ & $1.49 \mathrm{E}-04$ & 75 \\
\hline Pd & $<4.00 \mathrm{E}-04$ & & \\
\hline $\mathbf{R h}$ & $<2.00 \mathrm{E}-04$ & & \\
\hline $\mathbf{R u}$ & $<2.00 \mathrm{E}-04$ & & \\
\hline $\mathbf{s b}$ & $<8.00 \mathrm{E}-05$ & & \\
\hline Se & $<1.00 \mathrm{E}-04$ & $4.97 \mathrm{E}-05$ & \\
\hline si & $2.30 \mathrm{E}-02$ & $1.91 \mathrm{E}-02$ & 83 \\
\hline Sn & $<2.00 \mathrm{E}-03$ & & \\
\hline Sr & 3.30E-04 & $3.33 \mathrm{E}-04$ & 101 \\
\hline $\mathrm{Te}$ & $<3.00 \mathrm{E}-04$ & & \\
\hline Th & $<1.00 \mathrm{E}-03$ & & \\
\hline $\mathbf{T i}$ & 4.00E-05 & $4.67 \mathrm{E}-05$ & 117 \\
\hline $\mathrm{TI}$ & $<8.00 \mathrm{E}-04$ & & \\
\hline $\mathrm{U}$ & $2.60 \mathrm{E}-03$ & $4.08 \mathrm{E}-03$ & 157 \\
\hline $\mathbf{v}$ & $<2.00 \mathrm{E}-05$ & & \\
\hline $\mathbf{w}$ & $<1.00 \mathrm{E}-04$ & & \\
\hline $\mathbf{Y}$ & $<2.00 \mathrm{E}-05$ & & \\
\hline $\mathbf{Z n}_{\mathbf{n}}$ & $1.00 \mathrm{E}-04$ & $2.81 \mathrm{E}-04$ & 281 \\
\hline $\mathbf{Z r}_{\mathbf{r}}$ & $2.40 \mathrm{E}-04$ & $1.25 \mathrm{E}-04$ & 52 \\
\hline $\mathrm{NO}_{3}^{-}$ & (c) & (c) & (c) \\
\hline $\mathrm{NO}_{2}$ & (c) & (c) & (c) \\
\hline $\mathrm{PO}_{4}{ }^{3-}$ & $2.40 \mathrm{E}-01$ & $1.33 \mathrm{E}-01$ & 55 \\
\hline $\mathrm{SO}_{4}{ }^{2-}$ & $3.00 \mathrm{E}-02$ & $1.22 \mathrm{E}-02$ & 41 \\
\hline $\mathrm{F}^{*}$ & $<3.9 \mathrm{E}-02$ & $2.42 \mathrm{E}-02$ & \\
\hline $\mathrm{Cl}^{\circ}$ & (c) & $2.91 \mathrm{E}-03$ & \\
\hline $\mathrm{Br}$ & $<3.9 \mathrm{E}-02$ & & \\
\hline
\end{tabular}


Table F.5. Concentrations of the Radioactive Sludge Components in the Various Process Streams From the T-104 Test

\begin{tabular}{|c|c|c|c|c|}
\hline \multirow[b]{2}{*}{ Component } & \multicolumn{4}{|c|}{ Concentration, $\mu \mathrm{Ci} / \mathrm{mL}$} \\
\hline & $\begin{array}{c}\text { Retrieval } \\
\text { Solution (E) }\end{array}$ & $\begin{array}{c}\text { First Caustic } \\
\text { Leach }(G)\end{array}$ & $\begin{array}{l}\text { Second Caustic } \\
\text { Leach (I) }\end{array}$ & Wash (K) \\
\hline Total Alpha & $<2.55 \mathrm{E}-05$ & $<1.70 \mathrm{E}-05$ & $3.49 \mathrm{E}-05$ & $<2.55 \mathrm{E}-05$ \\
\hline${ }^{239,240} \mathrm{Pu}$ & $N D^{(a)}$ & ND & ND & ND \\
\hline $\begin{array}{l}{ }^{241} \mathrm{Am}+{ }^{238} \mathrm{Pu} \\
{ }^{241} \mathrm{Am}(\gamma)\end{array}$ & $\begin{array}{c}\text { ND } \\
<2.00 \mathrm{E}-05\end{array}$ & $\begin{array}{c}\text { ND } \\
<3.00 \mathrm{E}-05\end{array}$ & $\begin{array}{c}\text { ND } \\
<3.00 \mathrm{E}-05\end{array}$ & $\begin{array}{c}\mathrm{ND} \\
<2.00 \mathrm{E}-05\end{array}$ \\
\hline${ }^{137} \mathrm{Cs}$ & $1.07 \mathrm{E}-04$ & $7.55 \mathrm{E}-02$ & $8.07 \mathrm{E}-02$ & $3.03 E-02$ \\
\hline${ }^{90} \mathrm{Sr}$ & $<4.25 \mathrm{E}-04$ & $9.54 \mathrm{E}-02$ & $8.46 \mathrm{E}-04$ & $1.11 \mathrm{E}-03$ \\
\hline${ }^{99} \mathrm{Tc}$ & $<7.65 \mathrm{E}-06$ & $<7.65 \mathrm{E}-06$ & $<7.65 \mathrm{E}-06$ & $<7.65 \mathrm{E}-06$ \\
\hline
\end{tabular}

Concentration, $\mu \mathrm{Ci} / \mathrm{g}$

\begin{tabular}{lc} 
Component & Residue \\
\hline${ }_{\text {Total Alpha }}$ & $1.28 \mathrm{E}+\infty$ \\
${ }^{239,240} \mathrm{Pu}$ & $1.09 \mathrm{E}+00$ \\
${ }^{241} \mathrm{Am}+{ }^{238} \mathrm{Pu}$ & $1.85 \mathrm{E}-01$ \\
${ }^{241} \mathrm{Am}(\gamma)$ & $1.79 \mathrm{E}-01$ \\
${ }^{137} \mathrm{Cs}$ & $3.80 \mathrm{E}-01$ \\
${ }^{90} \mathrm{Sr}$ & $2.56 \mathrm{E}+01$ \\
${ }^{99} \mathrm{Tc}$ & $7.42 \mathrm{E}-04$
\end{tabular}

(a) ND $=$ Not Determined. The low alpha total alpha activity made these separations impratical. 
Table F.6. Distribution of the Radioactive Sludge Components Between the Various Process Streams From the T-104 Test

Amount of Component Found, \%

\begin{tabular}{|c|c|c|c|c|c|}
\hline \multirow[b]{2}{*}{ Component } & \\
\hline & $\begin{array}{c}\text { Retrieval } \\
\text { Solution (E) }\end{array}$ & $\begin{array}{l}\text { First Caustic } \\
\text { Leach (G) }\end{array}$ & $\begin{array}{c}\text { Second Caustic } \\
\text { Leach (I) }\end{array}$ & Wash (K) & Residue (A) \\
\hline Total Alpha & 0 & 0 & 0 & 0 & 100 \\
\hline${ }^{239,240} \mathrm{Pu}$ & (a) & (a) & (a) & (a) & 100 \\
\hline${ }^{241} \mathrm{Am}+{ }^{238} \mathrm{Pu}$ & (a) & (a) & (a) & (a) & 100 \\
\hline${ }^{241} \mathrm{Am}(\gamma)$ & 0 & 0 & 0 & 0 & 100 \\
\hline${ }^{137} \mathrm{Cs}$ & 0 & .25 & 30 & 14 & 31 \\
\hline${ }^{90} \mathrm{Sr}$ & 0 & 1 & 0 & 0 & 98 \\
\hline${ }^{99} \mathrm{Tc}$ & 0 & 0 & 0 & 0 & 100 \\
\hline
\end{tabular}

(a) Not determined due to a lack of total activity in the sample.

Table F.7. Mass Balance for Radioactive Sludge Components From the T-104 Test

\begin{tabular}{|c|c|c|c|}
\hline \multirow[b]{2}{*}{ Component } & \multicolumn{2}{|c|}{ Concentration in Dried Sludge, $\mu \mathrm{Ci} / \mathrm{g}$} & \multirow[b]{2}{*}{ Recovery, \% } \\
\hline & Direct Analysis & Summation Method & \\
\hline Total Alpha & 5.22E-01 & $6.37 \mathrm{E}-01$ & 122 \\
\hline${ }^{239,240} \mathrm{Pu}$ & $3.83 \mathrm{E}-01$ & $5.42 \mathrm{E}-01$ & 142 \\
\hline${ }^{241} \mathrm{Am}+{ }^{238} \mathrm{Pu}$ & 1.39E-01 & $9.20 \mathrm{E}-02$ & 66 \\
\hline${ }^{241} \operatorname{Am}(\gamma)$ & $7.18 \mathrm{E}-02$. & $8.90 \mathrm{E}-02$ & 124 \\
\hline${ }^{137} \mathrm{Cs}$ & $2.39 \mathrm{E}+\infty$ & $6.17 \mathrm{E}-01$ & 26 \\
\hline${ }^{90} \mathrm{Sr}$ & $1.25 \mathrm{E}+01$ & $1.29 \mathrm{E}+01$ & 103 \\
\hline${ }^{99} \mathrm{Tc}$ & $<7.00 \mathrm{E}-04$ & $3.69 \mathrm{E}-04$ & \\
\hline
\end{tabular}



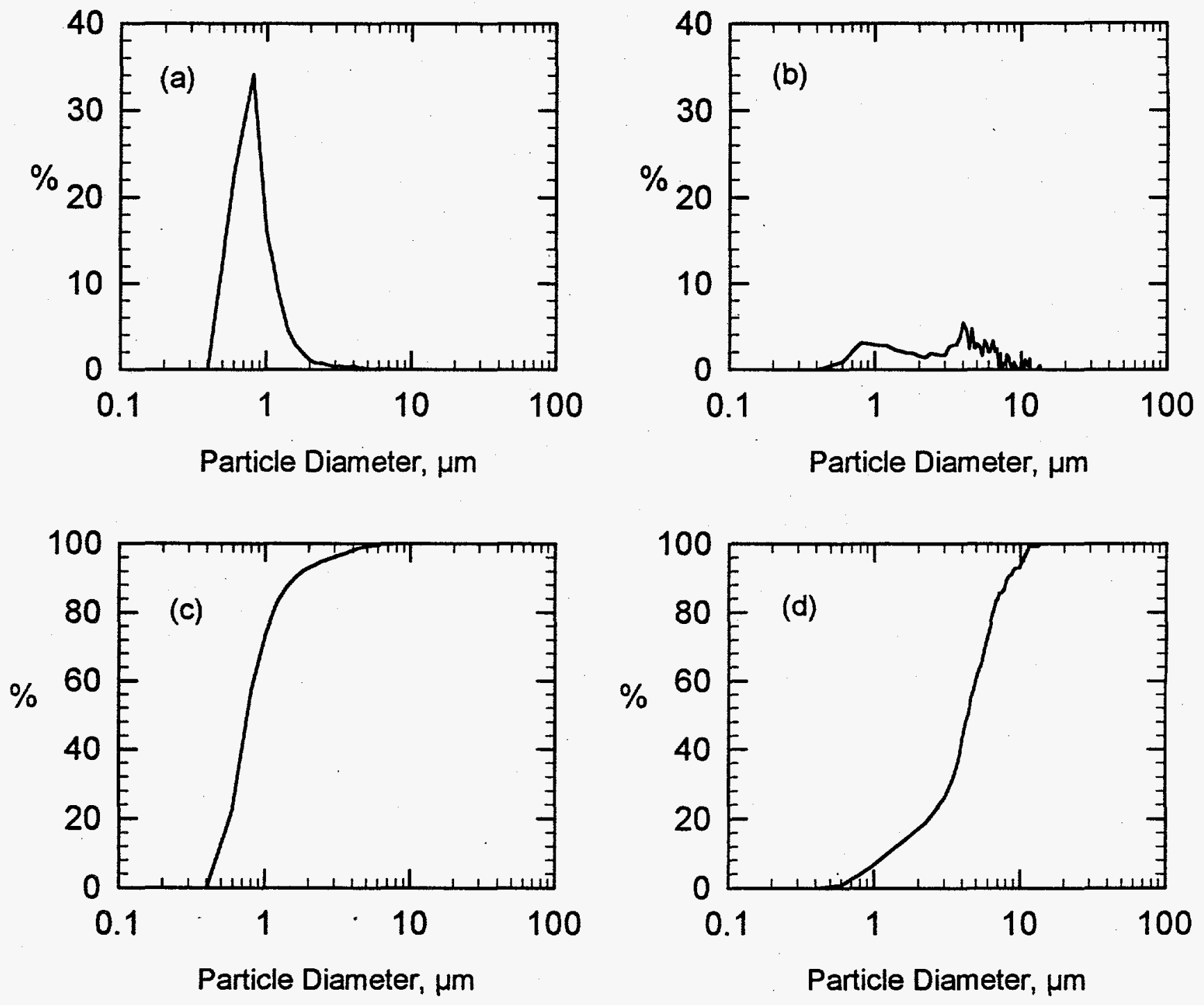

T104-C.SPW

Figure F.2. Particle-Size Data for Untreated T-104 Sludge: a) Probability-Number Density Graph, b) Probability-Volume Density Graph, c) Probability-Number Distribution Graph, and d) Probability-Volume Distribution Graph. 

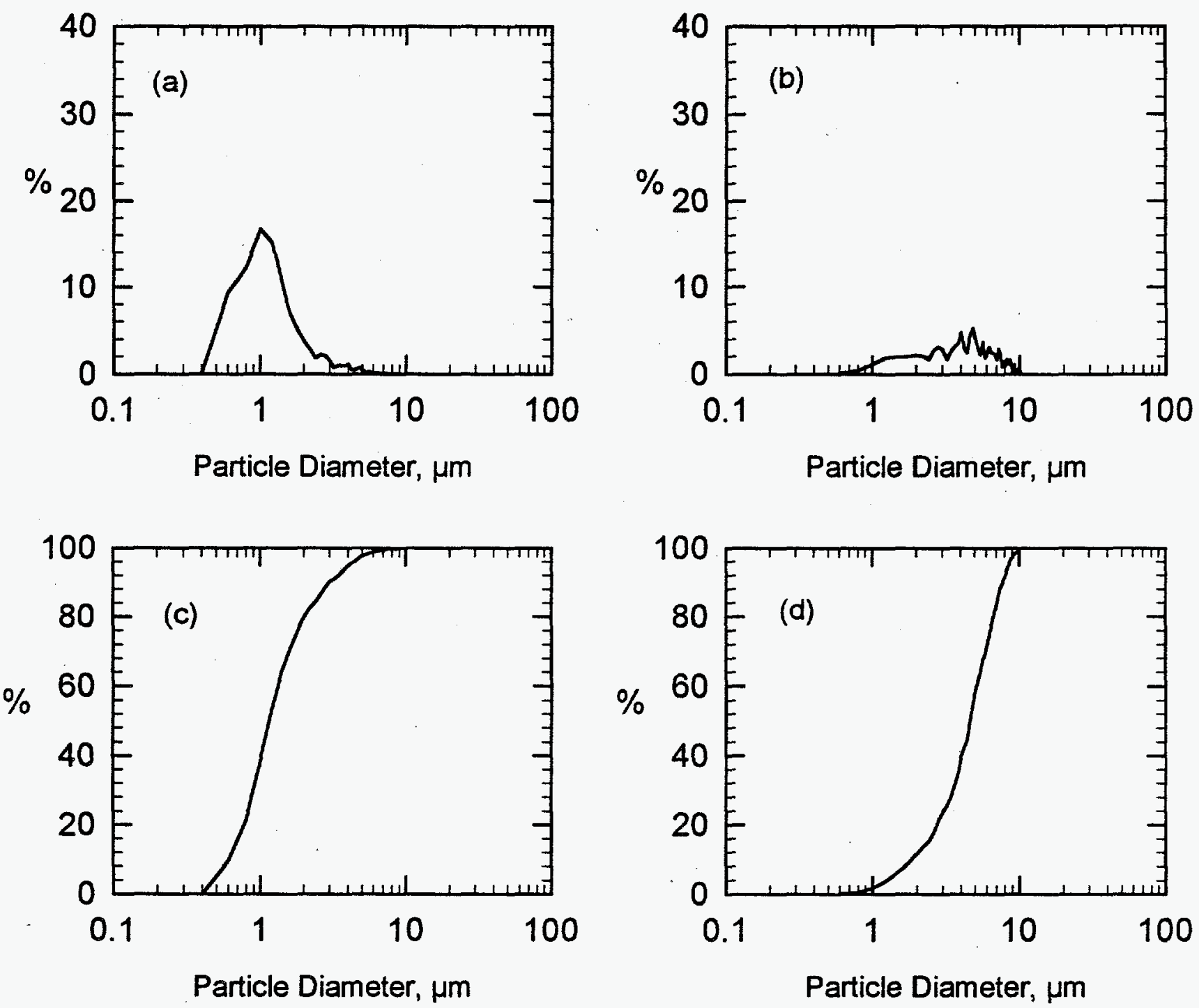

T104-M02.SPW

Figure F.3. Particle-Size Data for Treated T-104 Sludge: a) Probability-Number Density Graph, b) Probability-Volume Density Graph, c) Probability-Number Distribution Graph, and d) Probability-Volume Distribution Graph. 


\section{Appendix G}

Results from the Tank T-111 Sludge

Washing and Caustic Leaching Test 


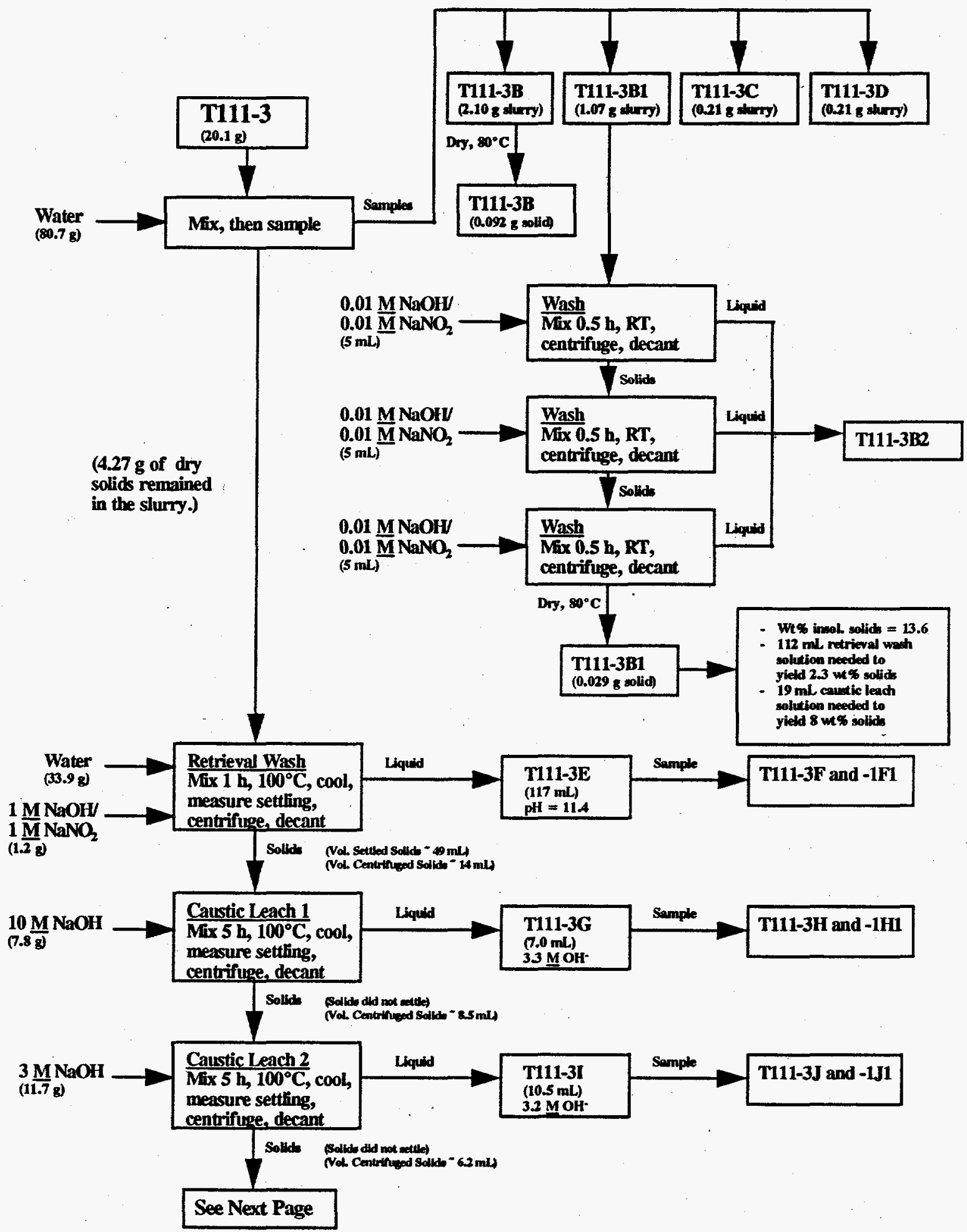

Figure G.1. Schematic of T-111 Sludge Washing and Caustic Leaching Test

G.1 


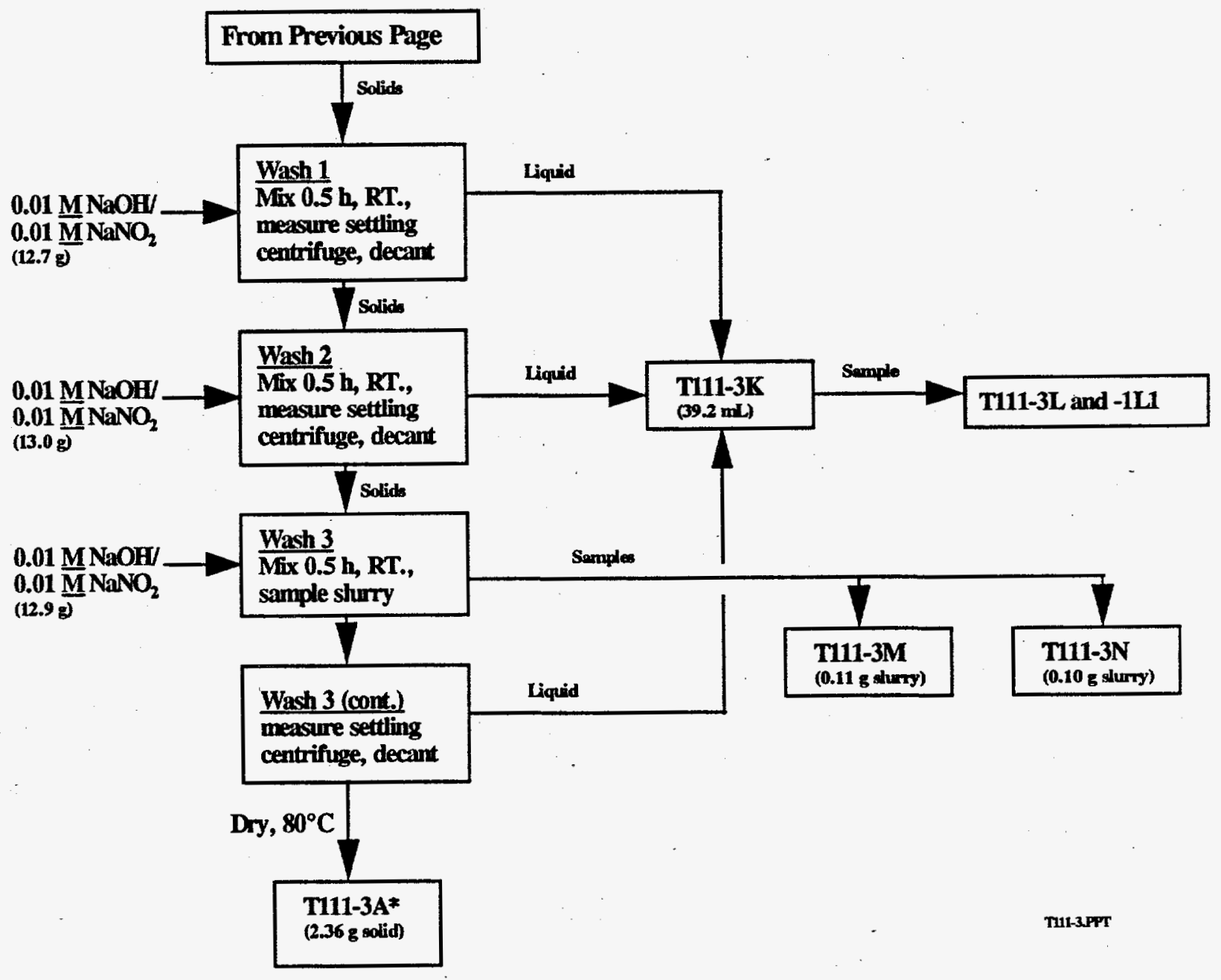

Figure G.1. (contd.) 
Table G.1. Concentrations of the Nonradioactive Sludge Components in the Various Process Solutions From the T-111 Test

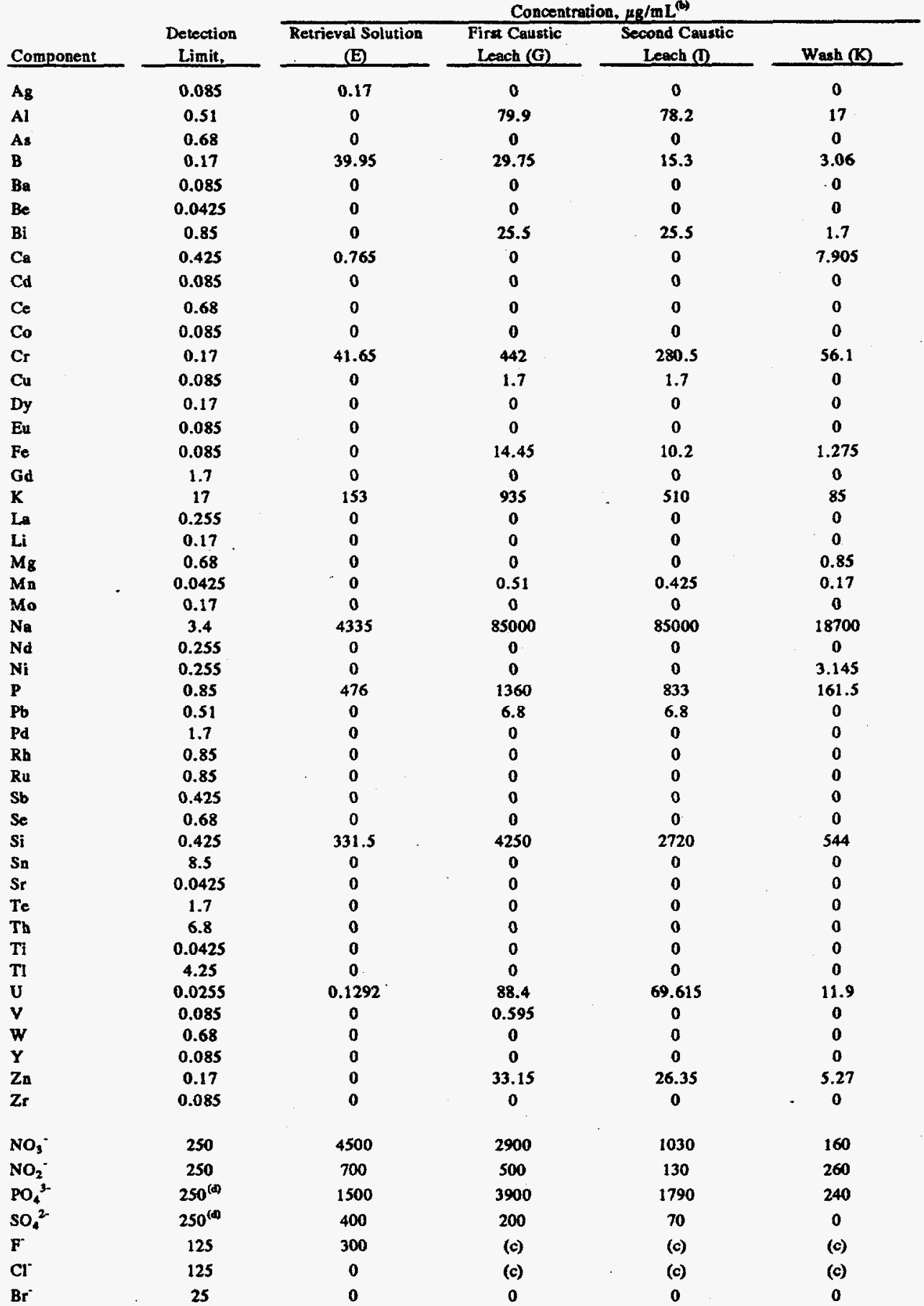

(a) The detection limits for the two caustic leach solutions (G and D) are five times the values reported in this column.

(b) Zero values indicate the analyte was below the detection limit.

(c) Measurement not performed.

(d) Phosphate and sulfate detection limits are $50 \mathrm{ug} / \mathrm{ml}$ for 2 nd leach and final wash steps. 
Table G.2. Concentrations of the Nonradioactive Sludge Components in the Leached Sludge From the T-111 Test

\begin{tabular}{|c|c|c|}
\hline Component & Detection Limit, $\mathrm{kg} / \mathrm{g}$ & Concentration, $\mu \alpha^{\prime} g^{(\omega)}$ \\
\hline Ag & 9 & 430 \\
\hline $\mathbf{A l}$ & 60 & 5700 \\
\hline As & 200 & 200 \\
\hline B & 20 & 1100 \\
\hline $\mathrm{Ba}$ & 9 & 330 \\
\hline Be & 5 & 0 \\
\hline Bi & 90 & 110000 \\
\hline $\mathbf{C a}$ & so & 22000 \\
\hline Cd & 9 & 60 \\
\hline ce & 80 & 200 \\
\hline Co & 9 & 60 \\
\hline Cr & 20 & 3200 \\
\hline Co & 9 & 240 \\
\hline Dy & 20 & 0 \\
\hline Eu & 9 & 10 \\
\hline $\mathbf{F e}$ & 9 & 130000 \\
\hline Gd & 200 & 400 \\
\hline $\mathbf{K}$ & (b) & (b) \\
\hline $\mathbf{L a}$ & .30 & 20000 \\
\hline$\overline{L i}$ & 20 & 0 \\
\hline$\overline{\mathrm{Mg}}$ & 80 & 4200 \\
\hline Mn & 5 & 96000 \\
\hline Mo & 20 & 40 \\
\hline $\mathbf{N a}$ & 200 & 56000 \\
\hline Nd & 30 & 300 \\
\hline $\mathbf{N i}$ & (c) & (c) \\
\hline $\mathbf{P}$ & 90 & 13000 \\
\hline Po & 60 & 3500 \\
\hline Pd & 200 & 0 \\
\hline $\mathbf{R h}$ & 90 & 100 \\
\hline $\mathbf{R u}$ & 90 & $\mathbf{0}$ \\
\hline $\mathbf{S b}$ & 50 & $\mathbf{0}$ \\
\hline se & $\boldsymbol{7 0}$ & 400 \\
\hline$\overline{\mathrm{Si}}$ & 50 & 34000 \\
\hline Sn & 900 & 1000 \\
\hline sr & 5 & 1300 \\
\hline Te & 200 & 0 \\
\hline Th & 800 & 0 \\
\hline $\mathbf{T i}$ & 5 & 1100 \\
\hline $\mathbf{T}$ & 500 & 0 \\
\hline $\mathbf{U}$ & 1585 & 39600 \\
\hline v & 9 & 0 \\
\hline $\mathbf{w}$ & 80 & 100 \\
\hline $\mathbf{Y}$ & 9 & 0 \\
\hline $\mathbf{z a}$ & 20 & 820 \\
\hline $\mathbf{z}$ & 9 & 120 \\
\hline $\mathrm{NO}_{3}^{-}$ & (d) & (d) \\
\hline $\mathrm{NO}_{2}^{-}$ & (d) & (d) \\
\hline $\mathrm{PO}_{4}^{3}$ & 24100 & 30000 \\
\hline $\mathrm{SO}_{4}^{2-}$ & 9600 & 10000 \\
\hline $\mathbf{F}$ & 24100 & $\mathbf{0}$ \\
\hline $\mathrm{CT}$ & (d) & (d) \\
\hline $\mathrm{Br}^{-}$ & (d) & (d) \\
\hline \multicolumn{3}{|c|}{ (a) Zero values indicate the analyte was below the detection limit. } \\
\hline \multicolumn{3}{|c|}{$\begin{array}{l}\text { (b) Posassium vahus are not reparted since the sample was diswolved } \\
\text { for anelysis using a KOH fusion method. }\end{array}$} \\
\hline
\end{tabular}

G.4 
Table G.3. Distribution of the Nonradioactive Sludge Components Between the Various Process Streams From the T-111 Test

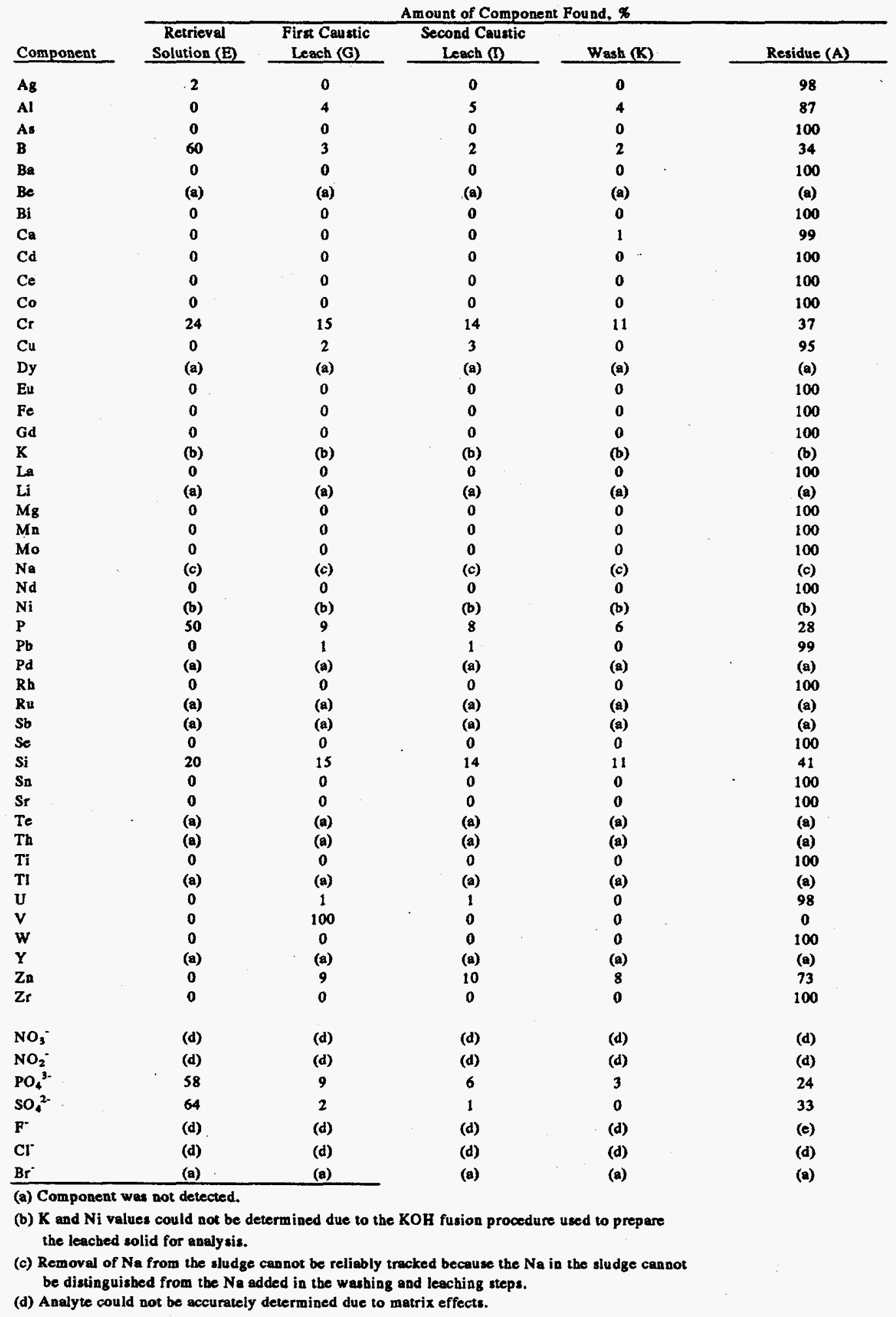


Table G.4. Mass Balance for Nonradioactive Sludge Components From the T-111 Test

\begin{tabular}{|c|c|c|c|}
\hline \multirow[b]{2}{*}{ Component } & \multicolumn{2}{|c|}{ Concentration in Dried Sludge, g/g Sludge ${ }^{(a)}$} & \multirow[b]{2}{*}{ Recovery, \% } \\
\hline & Direct Analysis & Summation Method & \\
\hline $\mathrm{Ag}$ & $2.00 \mathrm{E}-04$ & $2.40 \mathrm{E}-04$ & 120 \\
\hline Al & $4.90 \mathrm{E}-03$ & $3.68 \mathrm{E}-03$ & 75 \\
\hline As & $<3.00 \mathrm{E}-04$ & $1.12 \mathrm{E}-04$ & \\
\hline B & $7.50 \mathrm{E}-03$ & $1.84 \mathrm{E}-03$ & 25 \\
\hline Ba & $2.00 \mathrm{E}-04$ & $1.85 \mathrm{E}-04$ & 93 \\
\hline $\mathrm{Be}$ & $<2.00 \mathrm{E}-05$ & & \\
\hline Bi & $6.30 \mathrm{E}-02$ & $6.18 \mathrm{E}-02$ & 98 \\
\hline $\mathrm{Ca}$ & $1.60 \mathrm{E}-02$ & $1.24 \mathrm{E}-02$ & 78 \\
\hline Cd & $5.00 \mathrm{E}-05$ & $3.36 \mathrm{E}-05$ & 67 \\
\hline $\mathrm{Ce}$ & $<3.00 \mathrm{E}-04$ & $1.12 E-04$ & \\
\hline Co & $1.00 \mathrm{E}-04$ & 3.36E-05 & 34 \\
\hline Cr & $4.50 \mathrm{E}-03$ & $4.90 \mathrm{E}-03$ & 109 \\
\hline Cu & $3.30 \mathrm{E}-03$ & $1.42 \mathrm{E}-04$ & 4 \\
\hline Dy & $<9.00 \mathrm{E}-05$ & & \\
\hline Eu & $<4.00 \mathrm{E}-05$ & $5.61 \mathrm{E}-06$ & \\
\hline $\mathbf{F e}$ & $6.00 \mathrm{E}-02$ & $7.30 \mathrm{E}-02$ & 122 \\
\hline Gd & $<9.00 \mathrm{E}-04$ & $2.24 \mathrm{E}-04$ & \\
\hline $\mathrm{K}$ & (b) & (b) & (b) \\
\hline La & $9.20 \mathrm{E}-03$ & $1.12 \mathrm{E}-02$ & 122 \\
\hline $\mathbf{L i}$ & $<9.00 \mathrm{E}-05$ & & \\
\hline $\mathbf{M g}$ & $2.00 \mathrm{E}-03$ & $2.36 \mathrm{E}-03$ & 118 \\
\hline $\mathbf{M n}$ & $5.30 \mathrm{E}-02$ & $5.38 \mathrm{E}-02$ & 102 \\
\hline Mo & $<9.00 \mathrm{E}-05$ & $2.24 \mathrm{E}-05$ & \\
\hline $\mathbf{N a}$ & $3.70 \mathrm{E}-01$ & & \\
\hline Nd & $3.00 \mathrm{E}-04$ & $1.68 \mathrm{E}-04$ & 56 \\
\hline $\mathbf{N i}$ & (b) & (b) & (b) \\
\hline $\mathbf{P}$ & $2.60 \mathrm{E}-02$ & $2.63 E-02$ & 101 \\
\hline $\mathbf{P b}$ & $2.00 \mathrm{E}-03$ & $1.99 \mathrm{E}-03$ & 100 \\
\hline Pd & $<1.00 \mathrm{E}-03$ & & \\
\hline $\mathbf{R h}$ & $<4.00 \mathrm{E}-04$ & $5.61 \mathrm{E}-05$ & \\
\hline $\mathbf{R u}$ & $<4.00 \mathrm{E}-04$ & & \\
\hline sb & $<2.00 \mathrm{E}-04$ & & \\
\hline $\mathrm{Se}$ & $<3.00 \mathrm{E}-04$ & $2.24 \mathrm{E}-04$ & \\
\hline si & $4.70 \mathrm{E}-02$ & $4.71 \mathrm{E}-02$ & 100 \\
\hline Sn & $<5.00 \mathrm{E}-03$ & $5.61 \mathrm{E}-04$ & \\
\hline $\mathrm{Sr}$ & $6.80 \mathrm{E}-04$ & $7.29 \mathrm{E}-04$ & 107 \\
\hline Te & $<9.00 \mathrm{E}-04$ & & \\
\hline Th & $<3.00 \mathrm{E}-03$ & & \\
\hline $\mathrm{Ti}$ & $3.60 \mathrm{E}-04$ & $6.17 \mathrm{E}-04$ & 171 \\
\hline $\mathrm{TI}$ & $<2.00 \mathrm{E}-03$ & & \\
\hline $\mathbf{U}$ & $2.26 \mathrm{E}-02$ & $2.26 \mathrm{E}-02$ & 100 \\
\hline $\mathbf{v}$ & $<4.00 \mathrm{E}-05$ & $9.87 \mathrm{E}-07$ & \\
\hline $\mathbf{w}$ & $<3.00 \mathrm{E}-04$ & $5.61 \mathrm{E}-05$ & \\
\hline $\mathbf{Y}$ & $<4.00 \mathrm{E}-05$ & & \\
\hline $\mathrm{Zn}$ & $1.30 \mathrm{E}-03$ & $6.29 \mathrm{E}-04$ & 48 \\
\hline $\mathbf{Z r}_{\mathbf{r}}$ & $<4.00 \mathrm{E}-05$ & $6.73 \mathrm{E}-05$ & \\
\hline $\mathrm{NO}_{3}$ & (c) & (c) & (c) \\
\hline $\mathrm{NO}_{2}^{-}$ & (c) & (c) & (c) \\
\hline $\mathrm{PO}_{4}{ }^{3-}$ & $5.00 \mathrm{E}-02$ & 7.15E-02 & 143 \\
\hline $\mathrm{SO}_{4}^{2-}$ & $2.00 \mathrm{E}-02$ & $1.72 \mathrm{E}-02$ & 86 \\
\hline $\mathbf{F}^{*}$ & $<3.7$ E-02 & (d) & (d) \\
\hline $\mathrm{Cl}^{-}$ & (c) & (c) & (c) \\
\hline $\mathrm{Br}^{-}$ & (d) & (d) & (d) \\
\hline
\end{tabular}

G.6 
Table G.5. Concentrations of the Radioactive Sludge Components in the Various Process Streams From the T-111 Test

Concentration, $\mu \mathrm{Ci} / \mathrm{mL}$

\begin{tabular}{|c|c|c|c|}
\hline \multicolumn{4}{|c|}{ Concentration, $\mu \mathrm{Ci} / \mathrm{mL}$} \\
\hline $\begin{array}{c}\text { Retrieval } \\
\text { Solution (E) }\end{array}$ & $\begin{array}{l}\text { First Caustic } \\
\text { Leach (G) }\end{array}$ & $\begin{array}{c}\text { Second Caustic } \\
\text { Leach (I) }\end{array}$ & Wash $(\mathrm{K})$ \\
\hline$<2.55 \mathrm{E}-5$ & $2.21 \mathrm{E}-05$ & 2.10E-05 & $<2.55 \mathrm{E}-5$ \\
\hline (a) & (a) & (a) & (a) \\
\hline (a) & (a) & (a) & (a) \\
\hline$<2.00$ E-05 & $<3.00$ E-05 & $<3.00 \mathrm{E}-05$ & $<2.00 \mathrm{E}-05$ \\
\hline $1.23 \mathrm{E}-02$ & $9.78 \mathrm{E}-02$ & $6.04 E-02$ & $1.16 \mathrm{E}-02$ \\
\hline$<4.25 \mathrm{E}-04$ & $<4.25 \mathrm{E}-04$ & $1.69 \mathrm{E}-03$ & $<4.25 \mathrm{E}-04$ \\
\hline 5.61E-06 & $<7.65 \mathrm{E}-06$ & $<7.65 \mathrm{E}-06$ & $<7.65 \mathrm{E}-06$ \\
\hline
\end{tabular}

Concentration, $\mu \mathrm{Ci} / \mathrm{g}$

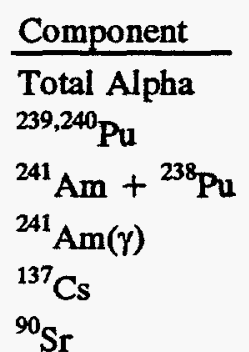

Total Alpha

${ }^{239,240} \mathrm{Pu}$

${ }^{241} \mathrm{Am}+{ }^{238} \mathrm{Pu}$

${ }^{241} \mathrm{Am}(\gamma)$

${ }^{137} \mathrm{Cs}$

${ }^{90} \mathrm{Sr}$

${ }^{99} \mathrm{Tc}$

${ }^{99} \mathrm{Tc}$
Residue

$3.12 \mathrm{E}+00$

$2.85 \mathrm{E}+\infty 0$

2.67E-01

4.74E-01

$1.08 \mathrm{E}+00$

$7.99 \mathrm{E}+01$

$1.95 \mathrm{E}-03$

(a) $\mathrm{ND}=$ Not Determined. The low total alpha activity made these separations impractical. 
Table G.6. Distribution of the Radioactive Sludge Components Between the Various Process Streams From the T-111 Test

\begin{tabular}{|c|c|c|c|c|c|}
\hline \multirow[b]{2}{*}{ Component } & \multicolumn{5}{|c|}{ Amount of Component Found, $\%$} \\
\hline & $\begin{array}{c}\text { Retrieval } \\
\text { Solution (E) }\end{array}$ & $\begin{array}{c}\text { First Caustic } \\
\text { Leach (G) }\end{array}$ & $\begin{array}{c}\text { Second Caustic } \\
\text { Leach (1) }\end{array}$ & Wash (K) & Residue (A) \\
\hline Total Alpha & 0 & 0 & 0 & 0 & 100 \\
\hline${ }^{239,240} \mathrm{Pu}$ & (a) & (a) & (a) & (a) & 100 \\
\hline${ }^{241} \mathrm{Am}+{ }^{238} \mathrm{Pu}$ & (a) & (a) & (a) & (a) & 100 \\
\hline${ }^{241} \mathrm{Am}(\gamma)$ & 0 & 0 & 0 & 0 & 100 \\
\hline${ }^{137} \mathrm{Cs}$ & 25 & 12 & 11 & 8 & 44 \\
\hline${ }^{90} \mathrm{Sr}$ & 0 & 0 & 0 & 0 & 100 \\
\hline${ }^{99} \mathrm{Tc}$ & 12 & 0 & 0 & 0 & 88 \\
\hline
\end{tabular}

a) Not determined due to a lack of total activity in the sample.

Table G.7. Mass Balance for Radioactive Sludge Components From the T-111 Test

\begin{tabular}{|c|c|c|c|}
\hline \multirow[b]{2}{*}{ Component } & \multicolumn{2}{|c|}{ Concentration in Dried Sludge, $\mu \mathrm{Ci} / \mathrm{g}$} & \multirow[b]{2}{*}{ Recovery, \% } \\
\hline & Direct Analysis & Summation Method & \\
\hline Total Alpha & $1.70 \mathrm{E}+00$ & $1.75 \mathrm{E}+\infty$ & 103 \\
\hline${ }^{239,240} \mathrm{Pu}$ & $1.49 \mathrm{E}+\infty$ & $1.60 \mathrm{E}+\infty$ & 107 \\
\hline${ }^{241} \mathrm{Am}+{ }^{238} \mathrm{Pu}$ & $2.31 \mathrm{E}-01$ & $1.49 \mathrm{E}-01$ & 65 \\
\hline${ }^{241} \mathrm{Am}(\gamma)$ & $2.55 \mathrm{E}-01$ & $2.66 \mathrm{E}-01$ & 104 \\
\hline${ }^{137} \mathrm{Cs}$ & $1.16 \mathrm{E}+\infty$ & $1.36 \mathrm{E}+\infty$ & 118 \\
\hline${ }^{90} \mathrm{Sr}$ & $4.11 \mathrm{E}+01$ & $4.48 \mathrm{E}+01$ & 109 \\
\hline${ }^{99} \mathrm{Tc}$ & $<7 \mathrm{E}-04$ & $1.25 \mathrm{E}-03$ & \\
\hline
\end{tabular}

G. 8 

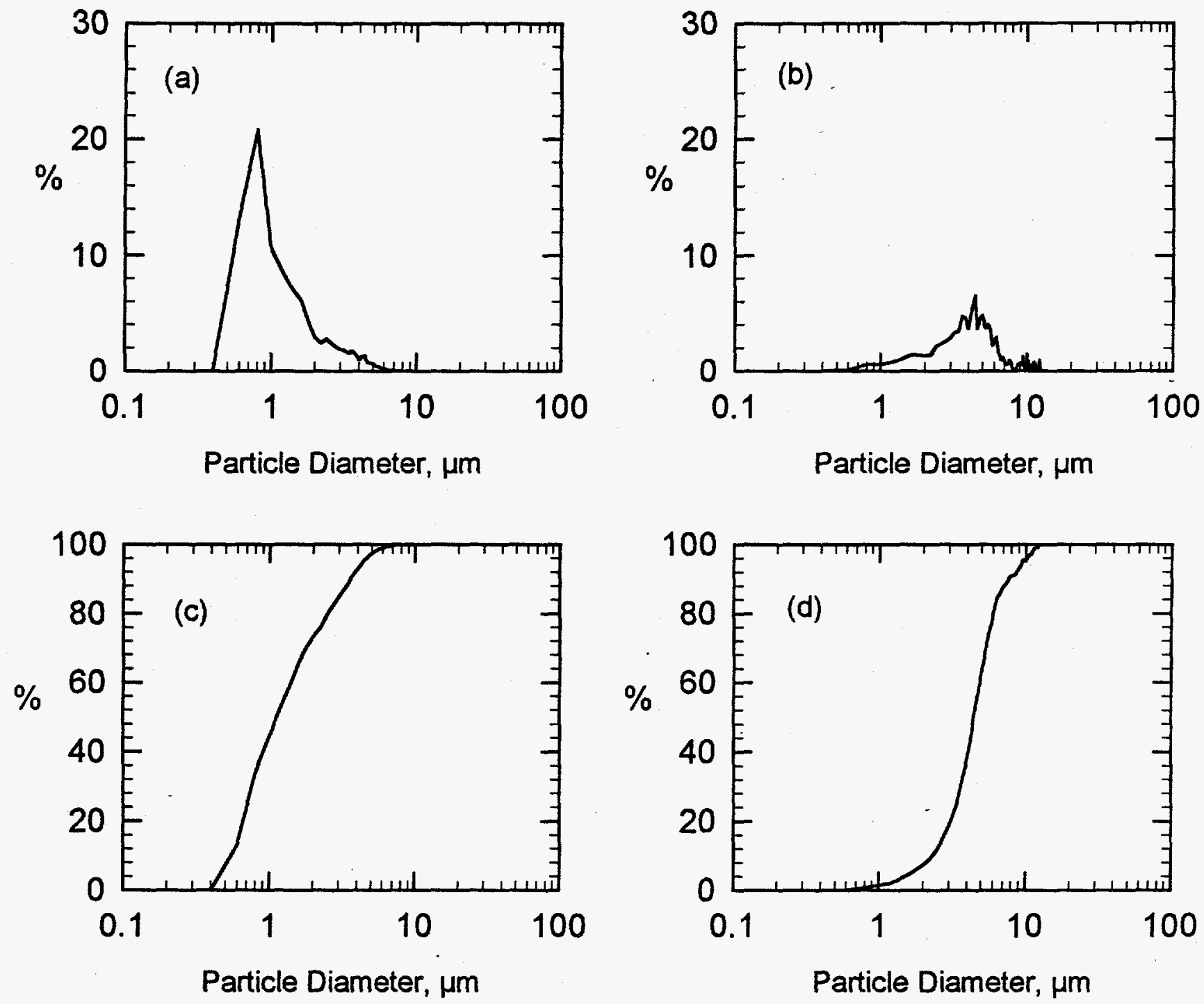

Figure G.2. Particle-Size Data for Untreated T-111 Sludge: a) Probability-Number Density Graph, b) Probability-Volume Density Graph, c) Probability-Number Distribution Graph, and d) Probability-Volume Distribution Graph. 

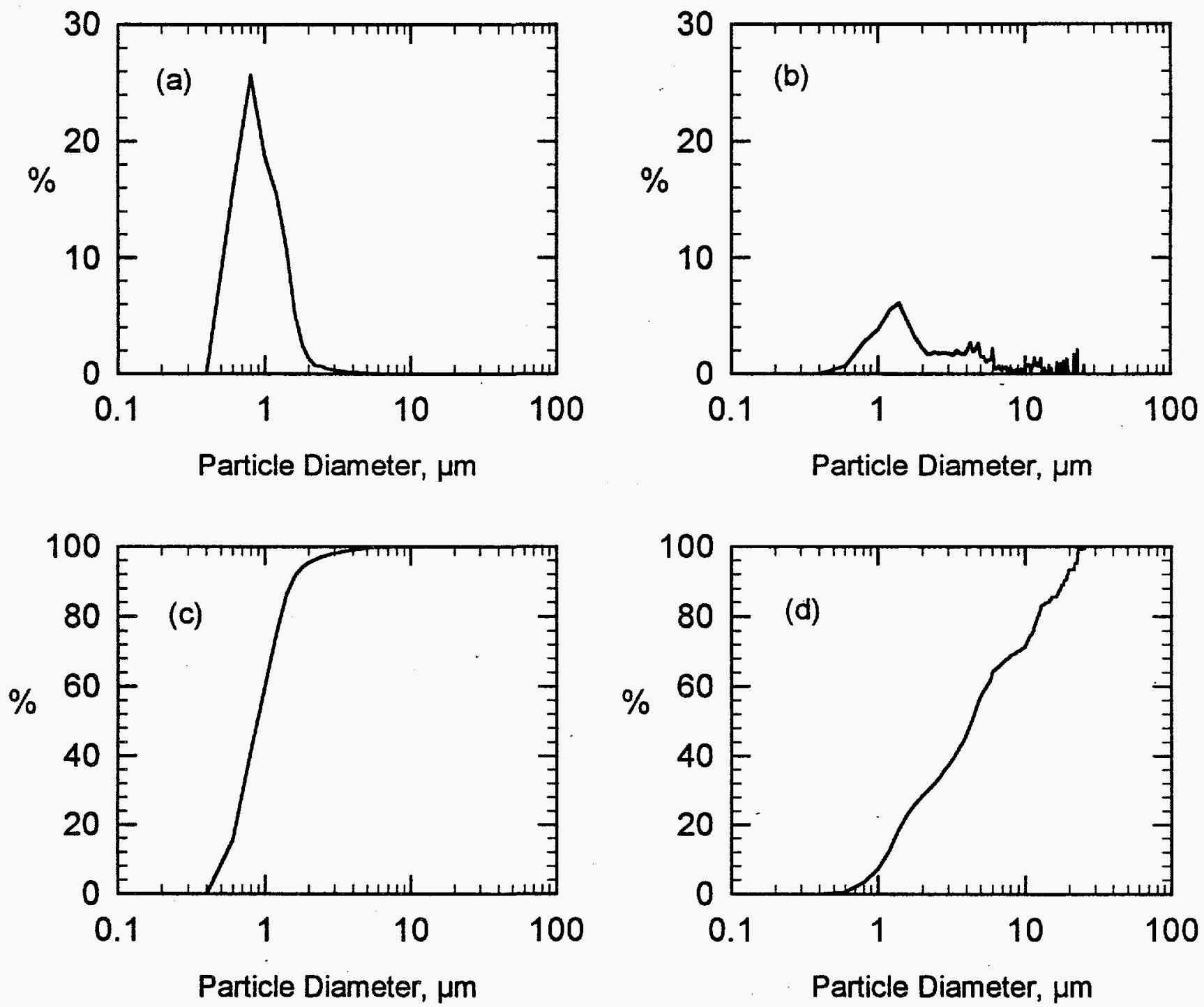

T111-3M.SPW

Figure G.3. Particle-Size Data for Treated T-111 Sludge: a) Probability-Number Density Graph, b) Probability-Volume Density Graph, c) Probability-Number Distribution Graph, and d) Probability-Volume Distribution Graph. 


\section{Distribution}

No. of

Copies

\section{Offsite}

12 DOE/Office of Scientific and Technical Information

Dennis Wynne

EM-361, Trevion II

U.S. Department of Energy

12800 Middlebrook Road

Germantown, MD 20874

Robert King

Washington Department of Ecology

P.O. Box 47600

Olympia, WA $98594-7600$

Donald Temer

Los Alamos National Laboratory

P.O. Box 1663

Mail Stop G740

Los Alamos, NM 87545

Steven Agnew

Los Alamos National Laboratory

P.O. Box 1663

Mail Stop J586

Los Alamos, NM 87545

Phil McGinnis

Oak Ridge National Laboratory

P.O. Box 2008

Oak Ridge, TN 37831-6273

Zane Egan

Oak Ridge National Laboratory

P.O. Box 2008

Oak Ridge, TN 37831-6223

Samuel D. Fink

Bldg. 773-A Rm. B-112

Westinghouse Savannah River Company

P. O. Box 616

Aiken, SC 29802

Dr. Denis Strachan

Argonne National Laboratory

9700 S. Cass Avenue

Argonne, IL 60439
No. of

Copies

Onsite

3 DOE Richland Operations Office
S. T. Burnum
P. E. Lamont
C. S. Louie

17 Westinghouse Hanford Company

J. N. Appel

H. Babad

G. R. Bloom

A. L. Boldt

S. J. Eberlein

K. A. Gasper

M. J. Klem

R. A. Kirkbride

M. J. Kupfer

S. E. Lambert

G. T. MacLean

R. M. Orme

I. E. Reep

D. A. Reynolds

B. C. Simpson

J. P. Sloughter

D. J. Washenfelder

ICF Kaiser Hanford

C. H. Brevick

70 Pacific Northwest Laboratory

G. H. Beeman

D. L. Blanchard

K. P. Brooks

G. H. Bryan

N. G. Colton

W. C. Cosby

A. R. Felmy

J. G. Hill

L. K. Holton (26)

D. E. Kurath

J. P. LaFemina

G. J. Lumetta (20)

B. M. Rapko (5)

B. A. Reynolds

R. D. Scheele

G. J. Sevigny

M. J. Wagner

Technical Report Files (5) 